UNIVERSIDADE DE SÃO PAULO

FACULDADE DE FILOSOFIA, LETRAS E CIÊNCIAS HUMANAS

DEPARTAMENTO DE FILOSOFIA

PROGRAMA DE PÓS-GRADUAÇÃO EM FILOSOFIA

Giovana Brolezi Leopoldo

Lei Natural e submissão:

Fundamentos da obediência

civil em Locke

Versão corrigida

São Paulo

2010 
Giovana Brolezi Leopoldo

\section{Lei natural e submissão: \\ Fundamentos da obediência civil em Locke}

Giovana Brolezi Leopoldo

Dissertação apresentada ao Programa de PósGraduação em Filosofia do Departamento de Filosofia da Faculdade de Filosofia, Letras e Ciências Humanas da Universidade de São Paulo, para obtenção do título de Mestre em Filosofia.

Orientador: Prof. Dr. Milton Meira do Nascimento

São Paulo 
Ficha Catalográfica

Leopoldo, Giovana

Lei Natural e submissão: Obediência civil em Locke / Giovana Brolezi Leopoldo. São Paulo: USP/FFLCH, 2010.

$192 \mathrm{f}$

Orientador: Professor Milton Meira do Nascimento.

Dissertação (mestrado) - Universidade de São Paulo. Faculdade de Filosofia, Letras e Ciências Humanas, 2010.

1. Lei Natural; 2. Razão; 3. Estado de Natureza; 4. Contratualismo; 5. Comunidade Política; 6. Governo; 7. Obediência 8. Resistência; 9. Confiança; 10. Ética e Filosofia Política - Tese. I. Nascimento, Milton Meira. II. Universidade de São Paulo, Faculdade de Filosofia. III. Titulo. 
“(...) Mas se alguém, forçando o outro, prescindindo de seu consentimento, impõe-lhe o que é correto, responda-me, como você chamará essa violência" (Platão: Político - 296a-b). 
A meus Pais, exemplo, razão e início dos sorrisos que me iluminam: minha Família 
Agradecer é reconhecer o apóio, demonstrar gratidão e apreço por alguém.

Assim,

a todos aqueles que direta e ou indiretamente, tornaram possível a realização desta pesquisa, meu muito obrigada.

E, como não poderia deixar de ser,

Agradeço,

A todos do Departamento de Filosofia, pessoas amigas, comprometidas com o serviço que prestam com carinho e seriedade para com todos.

Aos meus Professores, Alberto Ribeiro G Barros, Marco Antonio de Ávila Zingano, Milton Meira do Nascimento (também orientador), Nelson Rolf Kuntz e Sergio Cardoso, pela gratificante semeadura nas aulas, ensinamentos e discussões, não tão somente sobre "coisas da Filosofia", mas, sobretudo, pela lição de vida que cada um, com suas particularidades nos mostram, incentivando-nos nos caminhos do conhecimento.

Aos Professores Alberto e Rolf pelas valiosas observações no Exame de Qualificação, propiciando a conclusão deste trabalho. Sendo que, ao Professor Alberto, pelas inúmeras horas que, generosamente, concedeu-me para a reflexão deste trabalho. Também, à Professora Maria das Graças, de quem não tive a grata oportunidade de ter sido aluna, mas mesmo assim, permitiu-me muitas discussões sobre esta pesquisa.

A amiga Rose pela valiosa ajuda, leituras e discussões e generoso auxílio nesta caminhada,

A minha família como um todo, pelas infinitas horas roubadas do nosso convívio e pelo inestimável apoio, sem o qual este trabalho seria impossível.

E, com muito carinho, a todos da PRM-PP, indistintamente, verdadeiros amigos família, que cursaram "por tabela" este Mestrado comigo. A paciência, compreensão e amizade de todos, nestes anos, foram vitais para a conclusão deste curso. Mas, não seria justa, se não registrasse um obrigado especial a "Chefinha" e Amiga Vera, por segurar "as pontas", viabilizando este sonho antigo. Na verdade: a todos minha eterna gratidão.

Ainda e, sobretudo, como "everthing is full of god", Agradece-O, por tudo. 
Um agradecimento mais que especial:

Ao Professor Milton Meira do Nascimento, Mui Caro Professor e Orientador,

Que, generosamente, me acolheu. E, pelo seu paciente cultivo e dedicação sem o que não seria possível a presente germinação. 
Resumo

Leopoldo, Giovana Brolezi. Lei Natural e submissão: Fundamentos da obediência civil em Locke. 2010. 192f. Dissertação de Mestrado - Faculdade de Filosofia, Letras e Ciências Humanas - USP, 2010.

Este trabalho visa à compreensão do poder político e da legitimidade da sujeição civil, no pensamento de John Locke. O ponto chave é a análise dos sustentáculos de sua doutrina: Razão e Lei de Natureza, que delineiam uma teologia natural no seu pensamento, evidenciando a relação entre a ética e a política. Locke articula seu pensamento em função da noção de homem natural, de Deus e da Razão. O homem lockiano é um ser livre e racional, voltado a cumprir os desígnios do Criador: Deus, apresentando uma espécie de virtude natural. Necessário é explicitar o seu conceito de liberdade que é dado através da noção de igualdade, com a conseqüente ausência de subordinação entre os homens. Para isso, é necessário caracterizar o homem no estado de natureza e a sua opção voluntária e racional pela comunidade civil, através de um pacto social, voltado à instituição de um poder comum, do governo de leis e da maioria. As idéias centrais discutidas: lei natural, estado de natureza, pacto/consentimento, direito de resistência, homem virtuoso, legitimidade e fins do governo, podem evidenciar a noção de obediência como uma relação de confiança e forma de participação popular no governo de leis.

Palavras chaves: homem natural - Lei de Natureza - Razão - obediência - confiança 


\begin{abstract}
Leopoldo, Giovana Brolezi. Natural Law and submission: Civil obedience fundamentals in Locke - 2010. 192sheets. Master dissertation - Faculdade de Filosofia, Letras e Ciências Humanas - USP, 2010.

This work aims at understanding political power and legitimacy of civil liability in the thought of John Locke. The key point is the analysis of the underpinnings of his doctrine: Reason and Law of Nature, which outline a natural theology in his teaching, showing the relationship between ethics and politics. Locke articulates his thinking on the basis of the concept of natural man, God and Reason. The Lockean man is a racional and free being, dedicated to fulfill the desires of the Creator: God, presenting a kind of natural virtue. It is necessary to clarify the concept of freedom that is given through the notion of equality, with the consequent absence of subordination among men. Therefore, it's necessary to characterize the man in the state of nature and its rational and voluntary choice by the civil community, through a social pact, aimed at stablishing a common power, the government of laws and the majority. Central ideas discussed: natural law, the state of nature, consent agreement, right of resistance, virtuous man, legitimacy and purpose of government can demonstrate the notion of obedience as a confidence relationship and a form of popular participation in government of laws.
\end{abstract}

Key words: natural man - Law of Nature - Reason - obedience - confidence 
Sumário:

Resumo

Abstract

Introdução.

I - Razão e Lei Natural: prismas das relações naturais do ser lockiano .20

1.1 - Da Lei de Natureza .27

1. 2 - Da Condição Natural do Homem. .42

1.2.1 - Do Possível Estado de Guerra .52

1.2.2 - Relações e Ilações Naturais de Propriedade .59

1.3 - Paz e Guerra: as relações naturais do homem .72

II - Da comunidade de Homens à Comunidade Política. .84

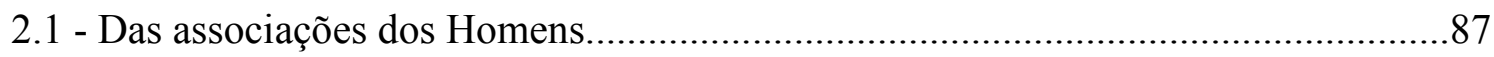

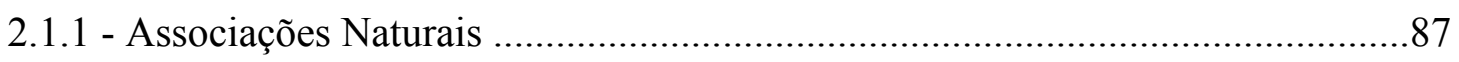

2.1.2 - A Comunidade Política ..................................................................................92

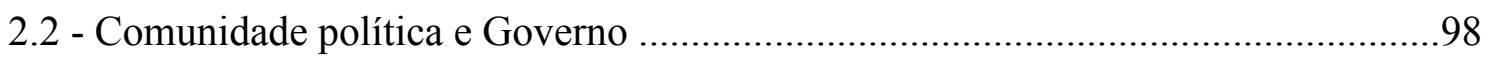

2.2.1 - Pacto de Associação e Pacto de Submissão ........................................................98

2. 3 - Da Comunidade política e do Governo: fins........................................................ 115

2.3.1 - Das formas e dos Poderes de uma Comunidade Política ................................119

III - Poder, Direitos e Deveres: o matiz da obediência e da resistência .................................134

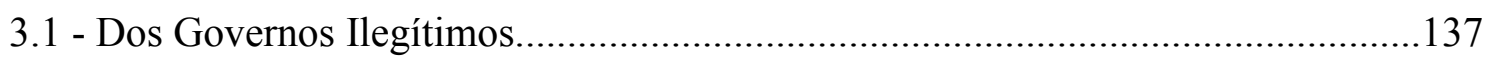

3.2 - Confiança e Resistência: confluência liberdade e obediência................................143

3.3 - Autoridade e obediência: peculiaridade do pensamento lockiano de 1960...........155

3.4 - A comunidade e o equilíbrio das relações entre os homens: premissas conclusivas 


\section{INTRODUÇÃO}

A doutrina política de Locke apresenta três aspectos fundamentais que sintetizam seu pensamento: a existência de uma lei de natureza; o estado de natureza - condição natural do ser humano - do qual extrai as diretrizes básicas à compreensão do poder político, e o consentimento como alicerce do corpo político, autorizando a sujeição política e impondo obrigações civis. Estes são os argumentos chaves do seu pensamento político que atribuem conotações morais a sua doutrina contratual sobre a origem da comunidade política.

O presente trabalho, sob o enfoque destes três eixos, volta-se à análise do dever fundamental da pessoa obrigada a um ordenamento jurídico: a obediência civil. De forma precisa, analisa "o que pode (e como) o Poder Soberano proibir/impor a seus cidadãos/súditos" e em que medida estes devem ou estão obrigados a obedecer. Responder a tal indagação é responder à pergunta: $\mathrm{O}$ que é o poder político e como ele se legitima.

A reflexão sobre a obrigação política - obediência civil - no pensamento político de John Locke tem acarretado leituras e interpretações várias. A regra é o entendimento de que na sua obra Dois Tratados Sobre o Governo, publicado em 1689, Locke expõe um tratado sobre a desobediência civil, a tal ponto de construir, não um direito, mas um dever de resistir ao governo ilegítimo, ao governo degenerado, com conotações individualistas, de autointeresse, fomentando a origem do pensamento liberal ${ }^{1}$.

De fato, nesta obra, sobretudo no Segundo Tratado, Locke apresenta um ensaio sobre a origem, a extensão e os fins do governo civil, estabelecendo as regras para a sujeição civil. Locke, esposando a doutrina contratualista da origem da sociedade política, apresenta a sujeição política como produto do consentimento humano. No contexto da doutrina política moderna, nosso autor não parte da polis, como comunidade de homens livres para explicar o

\footnotetext{
${ }^{1}$ A obra lockiana apresenta uma fortuna crítica extensa. Dentre tais leituras v.g., cita-se MACHPERSON (1979), para quem o Segundo Tratado apresenta uma justificativa para a dominação de uma classe ascendente, a burguesia. Já, ASCHCRAFT (1986), aponta Locke como um revolucionário de esquerda, e GOUGH (1973), em uma leitura ponderada, interpreta o pensamento lockiano como um meio termo entre as posições extremadas, mas que, de fato, penderia para um posicionamento mais esquerdista. Face a tais interpretações, John Dunn, refere-se a Locke como o filósofo de inúmeras faces, como, entre outras, o de "expoente do constitucionalismo liberal", de "ideólogo da nascente burguesia" ou de "populismo majoritário" (DUNN, 1986, p. 5). Na mesma linha, Peter Laslett, sobre as diferentes leituras da obra lockiana, pondera que Locke não "era, de fato, nem "socialista" nem "capitalista", embora seja fascinante encontrar elementos dessas duas posições em sua doutrina de propriedade - mais, talvez, naquilo que ele ignorou ou simplesmente deixou de afirmar do que em suas afirmações propriamente ditas" (LASLETT, 2003, p. 261). Os diferentes encaminhamentos de interpretações de seu pensamento, o que se denomina de "Locke's reception", ocorrem pelos vários argumentos que apresenta em seus textos, que podem suscitar ambiguidades em leituras isoladas do contexto de sua obra, como se pretende demonstrar na presente pesquisa.
} 
poder político. Seu ponto de partida é o individuo, o homem livre, igual e racional - senhor de direitos e obrigações, para depois chegar à sociedade política.

Os homens que antes viviam em estado de natureza, sem qualquer artifício da vida civil, por uma opção racional, decidem viver em uma sociedade política (pactum societatis), consentindo na instituição de um poder único (pactum subiectionis). Nesta ótica, na medida em que o governante distancie-se da regra matriz impulsionadora da vida civil, surge a autorização para insurreição civil.

Todavia, em Locke, o que aparece em jogo é o argumento de que a comunidade política surge para restabelecer a paz e a harmonia social outrora existente no estado de natureza -comunidade natural--, voltando-se à preservação do bem público (LOCKE, 2005, II,3). Não há em Locke indivíduos isolados presos aos seus próprios interesses, ao contrário, há uma sociabilidade imanente e homens livres que se congregam em busca do bem comum.

A comunidade política, substituindo a comunidade natural, pretende a preservação do ser humano e da própria humanidade. Isso implica no reconhecimento do homem como um ser diferenciado, como pessoa, sujeito de direitos e obrigações, proprietário de si mesmo, ou na expressão lockiana: proprietários em sua própria pessoa. E, ao mesmo tempo, como pertencente a um grupo maior: a humanidade - Mankind -, como uma grande comunidade natural de todo o gênero humano, distinta de todas as outras criaturas da terra (LOCKE, 2005, II, 128).

O pacto social volta-se à preservação do ser humano, o que impõe a preservação de sua propriedade, entendida esta como a liberdade, igualdade, a vida e bens materiais. É em função desta regra de preservação que os homens irão cumprir o desígnio divino: crescer e multiplicar (LOCKE, 2005, I, 41), preservando a humanidade. Criada para este fim, a comunidade política, formando um corpo único, passa a ter o poder de tomar decisões, de exigir a obediência e, eventualmente, autorizar a desobediência - a insurreição (LOCKE, 2005, II, 99).

O argumento trabalhado por Locke, na explicação da autoridade política, é o da liberdade versus a opressão ${ }^{2}$. A decorrência lógica da finalidade da sociedade civil então é que a obediência e a desobediência civil gravitam em torno da noção de liberdade e da igualdade,

\footnotetext{
${ }^{2} \mathrm{Na}$ interpretação do seu pensamento político, deve-se sempre considerar que este retoma a grande questão do Século XVII, a teoria do contratualismo e da obediência passiva e, especificamente na Inglaterra, os dois pólos de idéias políticas predominantes, quais sejam, Whig e Tory, que muito interferiram no encaminhamento da vida em sociedade e das relações do poder político e, consequentemente, nas teorias formuladas pelos filósofos da época
} 
despidas de qualquer conotação individualista, ou de interesses circunscritos às esferas particulares. A igualdade e a liberdade naturais que implicam na não subordinação entre os homens, não induz a uma posição individualista, ao contrário, estabelecem a cooperação e respeito mútuo para que alcance o fim da comunidade de homens: a paz e a Preservation of all Mankind (LOCKE, 1968, II, 7).

Em Locke, os homens independentemente do estado em que se encontrem, seja natural ou civil, sujeitam-se à lei de natureza, cujo preceito maior é a preservação de todos, prescrevendo que a ninguém é dado o direito de prejudicar outrem. A conseqüência é que os homens, na sua convivência, estreitam seus laços pela cooperação e confiança entre os mesmos.

Nosso autor encaminha-se para a elaboração de um "projeto político" que se fundamenta no ser humano como sujeito de obrigações. Obrigações para com o Criador, obrigações para consigo mesmo e obrigações em relação aos seus semelhantes. O seu pensamente político denota uma ética peculiar, implicando na instituição de uma comunidade política de homens livres e iguais com consciência e respeito em relação a si mesmos e à Humanidade.

A chave para a presente leitura é buscar evidenciar até que ponto as características do homem lockiano têm sido bem compreendidas. E, neste enfoque, pretende-se uma melhor compreensão do ser humano lockiano: livre, igual e racional - homem razão e sensação - que mais se aproxima de um sujeito de obrigações do que propriamente de direitos, verificando de que forma tais características determinam ou podem determinar o agir do homem natural e do homem cidadão. Este é o ponto de partida, determinado pelo próprio Locke, pois na sua linha de raciocínio, os homens devem sempre se lembrar quem são: artefatos do mesmo Criador, tendo as mesmas faculdades e compartilhando da mesma comunidade de natureza (LOCKE, 2005, II, 6).

No Ensaio Sobre o Entendimento Humano, Locke afirma que a mente humana é uma folha de papel em branco e que o homem está sujeito as suas experiências e reflexões para a aprendizagem. Segundo Locke, os homens, criaturas de Deus, nascem simples e ignorantes, não se apresentando como bons ou maus, e sim dotados de razão e sensações, suscetíveis ao bem e ao mal, devendo bem diligenciar sua conduta para se aproximarem dos desígnios de seu Criador: a boa vida na terra, para o bem viver no Além. 
O seu entendimento sobre a natureza humana, a sua teoria epistemológica influenciam a sua filosofia política, legando um conjunto de idéias que se pode denominar de "projeto político pedagógico". O homem é tanto senhor de seu próprio conhecimento, como de acordos políticos e, quanto maior for o seu grau de conhecimento, quanto mais entendimento tiver de como devem viver, maior será a sua participação política consciente e sua visão coletiva.

Para a análise da obra Dois Tratados Sobre o Governo, buscamos em algumas de suas outras obras, ou parte destas, o matiz para identificar o perfil do homem cidadão delineado por Locke, e a partir daí verificar as bases sobre as quais as questões relativas à obrigação política se sustentam, identificando os seus argumentos sobre a origem da sociedade política e do poder político ${ }^{3}$. A análise dos Dois Tratados, corroborados com algumas de suas idéias, espalhadas em outros textos, pode nos remeter à tese de que obrigação e responsabilidade mútuas circundam as relações de poder, seja qual for a esfera de interação entre os seres humanos.

Neste ponto, para captar o encadeamento das idéias políticas de Locke, observa-se que em escrito anterior, como o Two Tracts on Government (1660-1661), sem atribuir muita importância à origem da sociedade política, de forma acirrada, Locke zela pela necessidade da obediência civil de caráter individual, ainda que frente a possível governante arbitrárioilegítimo, como única forma de se ter a paz, a ordem e a harmonia social. Aqui, Locke enfatiza um dever individual, a obediência, para a preservação do coletivo.

Nos Ensaios Sobre a Lei de Natureza, escrito também anterior aos Dois Tratados, um verdadeiro código moral, de forma velada, estabelece a necessidade da obediência, prenunciando que esta tem alicerce no consentimento e entendimento de que o sustentáculo das relações entre os homens é a confiança e o interesse coletivo. Assim, como tudo na Natureza, o homem, como parte da Criação, nas suas relações também estaria sujeito a uma ordem para o bem viver, com reflexos na órbita privada e pública.

$\mathrm{Na}$ discussão do poder e das relações entre os homens, Locke ainda apresenta um esboço de um certo civismo vigoroso e de uma moralidade rígida na possível construção de um Estado Ético, como deixa entrever no seu Ensaio Sobre o Entendimento Humano e Alguns

\footnotetext{
${ }^{3} \mathrm{Na}$ análise de seu pensamento político, é inviável a leitura e análise de todas as suas obras, sobretudo em função do porte da presente pesquisa. Mas, visitar aspectos de suas idéias, espalhadas em alguns de seus textos, é algo necessário para uma possível compreensão de seu entendimento sobre o dever fundamental do ser humano em uma comunidade política: a obediência civil.
} 
Pensamentos Sobre a Educação. Aqui, Locke delineia um projeto pedagógico, levando em conta os vários aspectos das relações existentes entre os homens.

Nos Dois Tratados Sobre o Governo, o escopo de Locke era refutar a doutrina do direito divino dos reis e do absolutismo régio e, apresentar uma tese conciliando a liberdade do ser humano e a manutenção da ordem pública: autoridade e obediência. Para isso, Locke apresenta o seu contrato social e o consentimento, como base do poder político e fixação de limites do e para o governo. A proposição apresentada é que os homens, cônscios da necessidade da sociedade civil, decidem a quem obedecer.

Locke, neste contexto, traz à baila discussões relacionadas à Lei de Natureza, ao estado de natureza, à idéia da preservação da humanidade, ao pacto social, ao papel do consentimento, da obrigação decorrente das promessas, da relação sociável de confiança, de uma construção de moralidade peculiar que culminam na sua explicação sobre a origem e função do governo e fundamento da obediência civil. O foco da nossa pesquisa, análise dos argumentos lockianos sobre a obrigação política, seguirá essa linha de raciocínio.

Verificaremos em que medida a sujeição política gira em torno de seu tema clássico: a relação de confiança e noção de consentimento. Locke extrai os fundamentos das possíveis relações de subordinação entre os homens das próprias características do homem natural, e das justificativas da sociedade política. O princípio da confiança, conseqüência da lei de natureza e da marcante presença de Deus, impregna o seu pensamento político com uma teologia natural, com conseqüências peculiares para o ato de obedecer.

Locke trabalha, na construção de seu pensamento político, a dicotomia estado de natureza e estado civil. Segundo nosso autor, a substancial diferença entre esses dois estados é a ausência na terra, no estado de natureza, de um poder comum para julgar as eventuais contendas entre os homens, evidenciando a reciprocidade de poder, fruto da igualdade e liberdade inerentes a todos.

A proposta lockiana é evidenciar que ambos estados mantêm (ou devem manter) o sustentáculo das relações entre os homens: a lei de natureza e o princípio da confiança, que impõe a cooperação mútua. Daí então é que se deve considerar as razões pelas quais os homens buscaram a instituição de um governo único, deixando o estado de natureza, pactuando a criação da comunidade política, submetendo-se ao governo da maioria.

No pensamento lockiano, a comunidade de homens possui como lei régia a Lei de Natureza, seja sob a ótica natural ou civil, permeando-se pelo elo da confiança. Pressupõe 
tanto a noção de autoridade e de obediência a um comando, como também o reconhecimento de um vínculo afetivo social entre os homens. A mola propulsora das possíveis relações entre os homens é a confiança, este é o plus decorrente da lei de natureza, regra mandatória da comunidade humana na busca do equilíbrio entre os homens iguais e livres, já que por este comando deve-se preservar a humanidade.

A relação de autoridade deve ser entendida nessa lógica, pois, mesmo na condição prépolítica, a lei de natureza já determina o dever de assistência e isso traz o elemento primordial das relações humanas: o trust lockiano. A confiança é o fator indispensável para a existência humana. Da mesma forma, a base da autoridade política e a legitimidade desta consistem

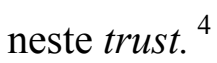

A ideia da confiança, como âmago da relação entre governo e governados, impõe a afirmação de que esta seria a condição da união entre os homens sob um governo e, sobretudo, do dever de obediência. De forma precisa, a relação se mantém enquanto se mantém a confiança mútua. Ambas as partes, governo e governados, confiam que cada um irá manter e cumprir o seu papel: o governo, de bem governar, e os súditos, de obedecerem, na medida em que todos encaminhem suas ações para o propósito último da criação da sociedade política: o bem comum, o bem-estar de todos. Aqui se destaca a obrigação moral de cumprir os compromissos assumidos, essência das relações entre os homens: confiança no ser humano e na preservação da humanidade.

A regra é que, no interior do contratualismo, a obediência ao governo é um efeito da obrigação de cumprimento das promessas. Para Locke, de fato, esta é a norma de regência das relações humanas, o fundamento da obediência está na consciência das obrigações decorrentes das promessas. $\mathrm{O}$ ato de consentir envolve esta noção de que todos vão agir em prol do bem comum. Há um fundamento no próprio consentimento que envolve a promessa de respeitá-lo, surgindo a obrigação decorrente das promessas.

Locke, ao admitir a importância do consentimento para a vida social e para a

\footnotetext{
${ }^{4}$ Nos Ensaios, datados de 1663-1664, Locke procura evidenciar (Ensaio VIII) que a base das relações humanas é a confiança, mostrando que não é o interesse privado de cada um que vem a ser o fundamento da lei de natureza. $\mathrm{Na}$ medida em que afasta o interesse particular, a própria vantagem e o egoísmo como base da lei de natureza, Locke mostra que práticas virtuosas é que são responsáveis pelos elos das comunidades. Caso prevalecesse o interesse individual, a vida em sociedade seria algo impraticável e a confiança (elo que une a todos) impossível. Ademais, haveria uma flagrante contradição na lei de natureza, pois seria impossível conciliar o interesse egoísta e a preservação da humanidade. Todavia, para Locke a prática voltada ao bem de todos não é um mero cálculo matemático, uma mera prática utilitária e racional desprovida de sentimento de irmandade, ao contrário, apresenta conotações de prática virtuosa, pois todos se reconhecem como iguais. A consequência é o risco que se assume: todos confiam que cada um irá agir de forma a não prejudicar a outrem, ou seja, suas ações voltam-se à preservação da humanidade.
} 
obediência ao governo, traz à baila a discussão sobre convenções e o cumprimento de promessas dela decorrente, como sustentáculo da comunidade política. Na fortuna de crítica à doutrina do contrato social, sob a relação da confiança, chamamos a atenção à afirmação de que a natureza humana é imediatista e a observância da justiça em prol de interesses particulares é que sustentaria sociedade política.

A proposta lockiana de um Estado Ético tende a imputar ao dever civil de obediência tanto o fundamento da promessa como o interesse da preservação da justiça: preservação da própria sociedade, mas com a conotação de uma consciência de coletividade, inclusive pregando a resignação individual em favor do coletivo.

A tendência lockiana é o cumprimento de obrigações desvinculadas de sanções ou recompensas. Propondo o bem agir, seja na esfera pública ou na órbita privada, para o bemestar de todos. Procura desvincular a noção de obrigação de sanções, buscando relacioná-la à responsabilidade que se tem com a humanidade, apresentando conotações racionais ao agir. Locke busca o "agir pela razão e com a razão".

A expressão All the world was América retrata a virtude natural presente em Locke. A figura do índio e do suíço, estabelecendo compromissos entre si (LOCKE, 2005, II, 14), é o paradigma lockiano do instinto de confiança na humanidade e da assistência mútua, que talvez, a complexidade das relações humanas veio a macular. O importante é considerar que a moral não é uma moral contratual, nascida após o pacto social para garantir a vida em paz e segurança. O compromisso moral que advém do pacto tem suporte na obrigação natural, que regula as relações humanas na condição natural do homem.

O homem delineado por Locke é um ser consciente da igualdade e da liberdade de todos. Este reconhecimento é o elemento chave da isonomia de poder e definição da estrutura da sociedade política. Para isso, procura transpassar a idéia de uma cooperação e respeito naturais entre os homens, pois a regra de regência, preservação da humanidade, estabelece uma tendência a pugnar por uma virtude natural, tendência própria instintiva de preservaçãosobrevivência do gênero humano. Obedecer, nesta relação sociável de confiança, é de fato a retomada da "excelência do agir".

Neste enfoque, procurou-se desenvolver este trabalho sob o prisma de três pontos de discussão, na tentativa de sistematizar a proposta política lockiana. No primeiro ponto, discute-se a condição natural do ser humano e as possíveis relações que o envolvem, destacando as características do estado natural, a relevância do papel da lei de natureza, da 
razão e de Deus nestas relações, sem que, aparentemente, haja uma rígida hierarquia entre tais argumentos. Das características deste estado é que se pode evidenciar o ser humano como sujeito de obrigações, explicando a relação de confiança entre todos. Pode-se perquirir, aqui, sobre uma possível e implícita teologia natural na concepção política lockiana.

Discutiremos também os motivos determinantes da instituição da sociedade política (inconveniências do estado de natureza, como o estado de guerra) que irão traçar as características e normas de regência do poder civil - condição de legitimidade e legalidade para o exercício deste. A importância da lei para a definição da liberdade civil evidencia a sua proposta de governo da maioria e de leis. Assim, na sequencia, o segundo ponto trabalhado é a própria comunidade política e a idéia de contrato político jusnaturalista - pacto ou contrato social --, cujo respaldo é a consciência coletiva da obrigação de cumprir promessas, evidenciando a relação de confiança: o trust lockiano.

Sob o prisma da finalidade que circunda a instituição da comunidade política, o terceiro ponto de discussão busca delinear os mecanismos lockianos para evitar e identificar o uso arbitrário do poder político, formas degeneradas ou ilegítimas do poder, estabelecendo as regras para a desobediência, atribuindo a esta conotações de caráter coletivo. Neste tópico discute-se a preocupação de Locke com a própria formação-educação do ser humano, fator determinante para o equilíbrio das relações entre os homens livres e iguais.

A obediência e a resistência civil exigem uma consciência civilística, que por sua vez exige a consciência da função da comunidade política e das leis que disciplinam as relações humanas. Expressam um mecanismo para a aferição da legitimidade e ou legalidade do governo, como forma de participação popular da condução dos objetivos da comunidade política.

Locke não fala em "massa popular", o seu conceito de povo e de maioria enseja dúvidas. $O$ seu pensamento sobre a origem da propriedade privada pode suscitar ambigüidades. O seu direito de resistência pode aproximá-lo de revoluções inconseqüentes, entre outras várias interpretações de seu legado. Mas na análise de sua doutrina, percebe-se que a obediência, em verdade, significa participação. Insinua, de fato, a cidadania participativa.

Não é confortável ler Locke, e a leitura deste trabalho pode seguir a mesma regra. Sintetizar sua obra e pensamento seria impossível. Nosso autor escreveu sobre assuntos vários e não é tarefa fácil estabelecer liames e certezas sobre o "legado Locke". A despeito das 
várias "faces lockianas", e da tentativa de qualquer conclusão relativamente ao seu conjunto de ideias, ler Locke é registrar que no seu pensamento político, a relação entre os governados (espaço privado) e governo (espaço público) impõe a necessidade do cultivo de práticas virtuosas, mostrando a preocupação impar com a formação do homem-cidadão. A imbricação Ética e Política é elemento inquestionável. A nossa pesquisa visa isso: captar o que Locke nos apresenta, um tratado moral, a subsidiar o agir político, como uma forma de garantir a inicial harmonia que poderia ter regido a condição natural do homem. 


\section{CAPÍTULO I - Razão e Lei: prismas das relações naturais do ser lockiano}

A reflexão lockiana sobre a origem do poder político tem como ponto de partida a ideia de que os homens são naturalmente livres e iguais, o que acarreta algumas peculiaridades na organização social, produto de uma escolha, e nas condições pelas quais se tem por legítima a obediência civil. A sujeição política - a obediência civil - e os limites do poder - precisamente, deveres e direitos na órbita político-social -, analisados sob o prisma da doutrina da liberdade e da igualdade, ganham uma dimensão especial: por determinadas razões, os homens naturalmente livres, voluntariamente, concordam, consentem em se sujeitar a um poder político único. O consentimento voluntário passa a ser, então, o elemento-chave da sujeição política.

Locke concilia liberdade-igualdade e obediência, enfocando a sujeição política formal como uma participação civil consciente: o homem livre e igual não está, simplesmente, sujeito a uma autoridade política, ele participa da condução política da sua comunidade civil. De acordo com Locke, a sujeição civil voluntária, ou seja, o consentimento dos homens em um pacto social, pressupõe uma relação sociável de confiança, a qual sustenta - legitima - o vínculo entre governantes e governados. Consequentemente, a ausência desta confiança autoriza a resistência - desobediência - ao eventual poder político desacreditado.

Para resolver a aparente contradição entre liberdade e obediência, Locke esboça uma teologia natural ou um tratado moral que permeia todos os seus escritos, sejam de caráter político ou epistemológico, e que se constitui como o âmago de seu pensamento ${ }^{5}$.

\footnotetext{
${ }^{5}$ John Locke não apresenta uma "doutrina nova", é certo. Mas, talvez o diferencial, como concede John Dunn, consista no fato de que não apresenta um "vazio ético" ao construir a "sociedade política", pelo contrário, a moralidade, inegavelmente, permeia seus escritos, pois tudo e todos são regulados pela lei de natureza. (DUNN, 1991, p. 87). Abre-se um parêntese para asseverar que isso é um ponto chave que impõe a reflexão sobre certos "estigmas" lockianos ("locke's reception"): "teórico do individualismo", "precursor do liberalismo", "representante de uma classe em ascensão", "embrião do capitalismo", "teórico da propriedade privada", da "teoria da desobediência", entre outros que o seguem. O importante é que Locke nos convida a uma séria reflexão sobre o "poder" como um fato político, sendo certo que no contexto "pós-medieval" Locke veio a "dessacralizar" a ideia de poder, "tornando-o um fato político sob o controle das ordens do mundo e dos fenômenos temporais e laicos. Embora se refira a leis da natureza com remissão a fundo divino, sua obra é um importante passo para a reflexão autônoma da política" (BITTAR, 2008, p. 177-178). Ao mesmo tempo, alia o seu pensamento político a uma possível "ética natural". Com efeito, na medida em que se analisa a teoria de Locke sobre a associação dos homens, refletindo sobre a natureza destes - ser pensante, dotado de sensações e reflexões, sujeito ao bem e ao mal e à intranquilidade do desejo, que foge às misérias e busca a felicidade, tendo como regra base a lei natural (divina) -, pode-se perceber que o homem, enquanto pessoa, mais se aproxima de um sujeito de obrigações para o bem viver, do que de um sujeito de direitos, com sérias consequências no espaço público-privado.
} 
Em sua teoria política, Locke se utiliza de argumentos éticos para embasar uma relação sociável de confiança e para fundamentar o poder político. A verdadeira autoridade política surge do consentimento, do elo de confiança entre os homens. Assim, a compreensão da noção de consentimento e de obediência civil, bem como de sua função, requer necessariamente a elucidação da concepção do homem e da própria natureza humana. Esta é a articulação-chave de sua doutrina, com fundamentos e consequências peculiares que buscaremos analisar.

John Locke, para explicar a origem da comunidade política, parte da premissa de que todos os homens são livres e iguais, pois são criaturas de Deus, criados à Sua imagem e semelhança, para viverem sob o Seu desígnio, sem qualquer tipo de subordinação, como deixa claro nesta passagem do Segundo Tratado Sobre o Governo:

Pois sendo todos os homens artefatos de um mesmo Criador onipotente e infinitamente sábio, todos eles servidores de um Senhor soberano e único, enviados ao mundo por Sua ordem e para cumprir Seus desígnios, são propriedades de Seu artífice, feitos para durar enquanto a Ele aprouver, e não a outrem. E tendo todos as mesmas faculdades, compartilhando todos uma mesma comunidade de natureza, não se pode presumir subordinação alguma entre nós que nos possa autorizar a destruir-nos uns aos outros, como se fôssemos feitos para o uso uns dos outros, assim como as classes inferiores de criaturas são para o nosso uso (LOCKE, 2005, II, 6) ${ }^{6}$.

Locke enfatiza que todos os homens são iguais, portadores das mesmas faculdades, sem qualquer tipo de subordinação entre os mesmos. Reconhece somente a subordinação em relação ao Criador onipotente e sábio, a quem se deve obediência. Como um substrato a encaminhar seu pensamento político, Locke diviniza o ser humano, entendido como criatura de Deus à qual foi concedida uma capacidade que o diferencia dos demais habitantes da terra: a razão. De acordo com Locke, devemos sempre "dar graças a Deus" por nos conceder forças para "provermos ao conforto desta vida", bem como para "descobrir o caminho para nos conduzir a uma vida melhor no Além” (LOCKE, 2008, p. 24-25). Isso traz implicações peculiares na órbita social (esfera privada) e na órbita política (esfera pública), como se pretende demonstrar.

\footnotetext{
${ }^{6}$ Utilizamos a tradução de Júlio Fischer, publicada pela Martins Fontes (LOCKE, 2005). Observamos, relativamente ao sistema de citação da obra Dois Tratados Sobre o Governo que, quando no texto, a referência for para ambos, usaremos Dois Tratados. Quando for específica a cada um dos Tratados, usaremos a abreviatura e localização das referências da seguinte forma: Primeiro Tratado e Segundo Tratado, as citações são dadas, respectivamente, como I e II, acompanhados por um número de seção ou parágrafo correspondente, por algarismo arábico, e pelo nome do autor e ano do texto citado, v.g., Segundo Tratado, parágrafo sétimo: LOCKE, 2005, II, 7.
} 
Segundo Locke, a possibilidade de uma vida "boa e em harmonia" somente será possível através do correto uso da capacidade diferenciadora que é a razão, que nos permite conhecer “como diz São Pedro, 'todas as coisas que respeitem à vida e à piedade', ou seja, tudo o que convém às nossas necessidades e à formação da virtude" (LOCKE, 2008, p. 24)7

Para dissipar uma possível tensão entre igualdade, liberdade e certa independência entre os homens na relação sociável de confiança, John Locke esclarece que, como criaturas de Deus, os homens nascem livres e racionais, e é a racionalidade que proporcionará o conhecimento necessário para o bem viver em comunidade. Nas palavras de Locke, Deus deu o mundo aos homens em comum, "deu-lhes também a razão, a fim de que dela fizessem uso para maior benefício e conveniência da vida" (LOCKE, 2005, II, 26).

Ora, isso impõe uma incansável busca em conhecer regras relativas à conduta humana, para propiciar o "bem viver" e a formação da virtude, "por ser a única forma de nos aproximarmos de Deus, nosso Criador", e de termos uma "noção crítica de nossos próprios deveres" ${ }^{8}$. Nessa ótica, o esforço do homem é tentar compreender as regras, às quais as criaturas racionais se submetem ou devem se submeter para o convívio social e político ${ }^{9}$. As regras, segundo Locke, são ditadas pela Lei de Natureza.

A relação entre os homens, entre estes e o poder político, ou seja, as relações sociais e as da comunidade política operam ou devem operar sob a égide de uma ordem maior que Locke denomina de "Lei de Natureza", o que sugere uma "possível ordem universal". Na

\footnotetext{
${ }^{7}$ Nessa busca, Locke enfatiza que "o conhecimento do homem é, na verdade, muito pequeno, comparado com a perfeita e universal compreensão de quanto existe; mas bastam-lhe as luzes que tem para chegar ao conhecimento do seu Criador, como de seus deveres" (LOCKE, 2008, p. 25). Ora, Locke não descuidou um só momento de trabalhar a necessidade da moralidade na condução politicossocial das comunidades e do próprio homem. Estabelece, assim, certos princípios e ideias para dar vida à moralidade, pois a entende como uma ciência demonstrativa, com ideias e princípios a serem construídos e experimentados. O peculiar de sua construção é que não admite a existência de pluralidade de sistemas morais demonstráveis, ou seja, as ideias e princípios a serem construídos e experimentados na comprovação da mesma não podem se originar de múltiplos sistemas morais. Isso porque, como visto, parte do princípio de que há um Ser supremo, de infinito poder, bondade e sabedoria, que criou todos os homens iguais, sem subordinação entre os mesmos, pois são criaturas da mesma espécie, portadores de entendimento e de racionalidade. Sobretudo, Deus deu aos homens "a lei natural, a própria razão, que é uma lei absoluta, evidente e certa. A evidência e a certeza desta lei tiram os homens da confusão e da indecisão e os fazem cumpridores de sua missão. Estes princípios evidentes garantem uma ética demonstrável" (CAVALCANTI, 1999, p. 80).

${ }^{8}$ Segundo explica John Dunn, a teologia é a chave para a compreensão coerente da existência humana, ou seja, é o sustentáculo, a condição necessária da solidez para se compreender Locke. A liberdade religiosa vem a ser a condição necessária para que os homens compreendam, de forma correta, seus deveres em relação a Deus (DUNN, 1991, p. 264). Logo, a obediência à lei de natureza traz a promessa de uma boa vida para a alma.

9 A moralidade é tema capital no pensamento lockiano e, como observa Gough (1973, p. 5), “consiste em obedecer ao comando de Deus, não há uma idéia de moralidade sem a idéia de Deus". Este tipo de consciência procura mostrar o indivíduo, o homem com um só tipo de desígnio, com um só tipo de vontade: a do Criador.
} 
verdade, temos uma tentativa de construção da moralidade, pois a moral possui importante papel no conjunto de ideias políticas lockianas.

As seguintes assertivas, que serão retomadas mais à frente, apresentam três aspectos fundamentais da doutrina política de Locke, a saber: a existência de uma lei de natureza, que baliza o comportamento humano; o estado de natureza - condição natural do ser humano -, que fornece as diretrizes básicas para a compreensão de poder político; e o consentimento, como fundamento do corpo político, que permite a "sujeição política" - impõe obrigações civis:

Sendo todos os homens, como já foi dito, naturalmente livres, iguais e independentes, ninguém pode ser privado dessa condição nem colocado sob o poder político de outrem sem seu próprio consentimento (LOCKE, 2005, II, 95).

Para entender o poder político corretamente, e derivá-lo de sua origem, devemos considerar o estado em que todos os homens naturalmente estão, o qual é um estado de perfeita liberdade para regular suas ações e dispor de suas posses e pessoas do modo como julgarem acertado, dentro dos limites da lei da natureza, sem pedir licença ou depender da vontade de qualquer outro homem (LOCKE, 2005, II, 4).

Todo homem, ao consentir com outros homens em formar um único corpo político sob um governo único, assume a obrigação, perante todos os membros dessa sociedade, de submeter-se à determinação da maioria e acatar a decisão desta (LOCKE, 2005, II, 97).

As noções de lei de natureza, estado de natureza, consentimento e poder político e as articulações entre elas fornecem a chave do ideário ético-político de Locke ${ }^{10}$. É, portanto, sob esse enfoque que se deve analisar a sua doutrina, pensar a comunidade política e a relação de $\operatorname{poder}^{11}$.

O ponto de partida deve ser a análise da lei de natureza e o papel da razão na esfera das relações entre os homens livres e iguais. Isso fornece a base para a compreensão sobre a "origem, fundamento e finalidade do poder político", pois o "corpo político" somente possui

\footnotetext{
${ }^{10}$ É certo que tais ideias não eram novidade na época. Como observa Mario Grondona, Locke não "inovou", apenas "sistematizou e vulgarizou" um pensamento que "rondava a época", tornando-se o "cume de uma cordilheira", o primeiro grande nome do "liberalismo político", conseguindo humanizar a "idéia de poder, que se torna secular e "moderna'. Não há mais elementos religiosos nem despóticos no poder. O que há é o direito de cada homem, que cede livremente certo poder a um governo para que garanta a vida em sociedade" (GRONDONA, 2000, p. 20).

${ }^{11}$ É verdade que das assertivas acima se pode extrair mais questões relevantes da teoria política lockiana, a serem analisadas mais adiante, como a "diretriz" do corpo político determinado pela maioria, o próprio conceito de "maioria", "confiança e lealdade" e sua oposição: "quebra de confiança e resistência", entre outras. Mas, por ora, destacaremos os três aspectos indicados.
} 
legitimidade se e quando observada a lei de natureza (LOCKE, 2005, II, 12), que disciplina a conduta do homem dentro e fora do "pacto societário".

Na estrutura das relações humanas, a razão ou "luz da razão" é o guia para as ações dos homens, seres livres e racionais, propiciando a virtude e a "adequada modelagem" da moral. Perseguindo essa ideia, Locke afirma que a razão nada mais é do que a "própria lei de natureza, que comanda a vida dos homens" (NASCIMENTO, 2001, p. 1339). A presente afirmação poderia autorizar a conclusão de que não haveria "necessidade de se referirem a nenhuma autoridade, nem mesmo à divina, pois Deus, embora tenha sido o criador dos homens, não interfere nos seus negócios porque tendo lhe dado a razão, deu-lhes o instrumento para sua autonomia" (NASCIMENTO, 2001, p. 1339) ${ }^{12}$.

A Razão - faculdade que diferencia o ser humano dos outros animais - é o "eixo" de equilíbrio das ações humanas. É a mola propulsora que permite a construção/compreensão da lei natural, pilar sobre o qual se desenvolvem as teorias lockianas, seja a política, seja a do conhecimento humano ${ }^{13}$. Na definição de Locke:

revelação natural pela qual o eterno Pai da luz e fonte de todo o conhecimento comunica à humanidade aquela porção de verdade que pôs ao alcance das faculdades naturais: revelação é a razão natural aumentada por uma nova série de descobertas comunicadas imediatamente por Deus e das quais a razão garante a sua verdade, pelo testemunho e provas que dá acerca de proveniência de Deus. De modo que aquele que afasta a razão para abrir caminho à revelação extingue a luz de ambas e faz pouco mais ou menos o mesmo que se persuadisse um homem a tirar os olhos para receber melhor a luz remota de uma estrela invisível por meio de um telescópio (LOCKE, 2008, p. 969).

São várias as passagens de seu escrito político Dois Tratados sobre o Governo em que se refere à razão como "bússola" que norteia o bem viver dos homens, sendo extremamente marcante esta passagem do seu Primeiro Tratado:

Tal é o extremo de brutalidade, abaixo do nível dos animais, a que pode a mente em desassossego do homem conduzi-lo quando abdica ele da razão, a

\footnotetext{
${ }^{12}$ Ponto peculiar no pensamento lockiano: Deus, a Razão e a liberdade de escolha no fomento da construção da moralidade, unindo o racional (autonomia) e a crença na Divindade (submissão), como se pretende analisar, na presente pesquisa.

${ }^{13}$ John W. Yolton assinala que a razão, para Locke, é "a pedra de toque para a verdade e conhecimento; é também o guia para a ação. Neste último papel Locke usa as expressões 'luz da Razão' (Ensaio, p. 115) ou "razão certa"'. Assim, a razão vem a ser "a fonte de certos princípios definidos de ação, da qual dimanam todas as virtudes e tudo o que se fizer necessário, seja o que for para a adequada modelagem da moral" (YOLTON, 1996, p. 226). A referência é à lei de natureza que a razão pode descobrir. Ainda sobre o papel da "razão", Yolton lembra que "essa noção de modelagem da moral é um tema central em Alguns pensamentos referentes à educação. A razão é para controlar desejos na criança ou, em alguns casos, para autorizar desejos específicos" (Ibid., p. 226). Dessa forma, para Locke, a razão, aliada à fé, é o guia e o conselheiro da conduta humana.
} 
qual o coloca quase em igualdade com os anjos. Nem poderia ser de outra forma tratando-se de uma criatura cujos pensamentos são mais numerosos que os grãos de areia e mais vastos que o oceano, e a qual a fantasia e a paixão conduzem necessariamente por estranhos caminhos quando não é guiada pela razão, sua única estrela e bússola. (LOCKE, 2005, I, 58).

Locke ressalta que, uma vez guiados pela razão, os homens viveriam em harmonia e, inclusive, a instauração da ordem política poderia ser desnecessária. A razão, quando consultada, mostra que todos são iguais e independentes, e um ser humano igual não deveria prejudicar outro ser humano igual, "nas suas posses, saúde e liberdade" (LOCKE, 2005, II, 6).

Razão e lei de natureza são medidas fixadas por Deus às ações dos homens para mútua segurança destes (LOCKE, 2005, II, 8). A razão e a fé apresentam-se como problema e ao mesmo tempo solução na obra lockiana. Ao admitir a existência da lei de natureza, conhecível pela razão, Locke praticamente estabelece um código de regras ao homem, independentemente de qualquer ordenamento jurídico positivo. Leo Strauss, contundente crítico da "teologia natural" presente no seu pensamento político, faz a seguinte observação:

\begin{abstract}
Admitamos por um momento que Locke era um racionalista puro, isto é, que considerava a razão entregue a si mesma não só como "a única estrela e bússola" do homem, mas também como suficiente para conduzir o homem à felicidade, e que, por conseguinte, rejeitava a revelação por ser supérflua e, portanto, impossível. Mesmo nesse caso, dada a circunstância em que escreveu, os seus princípios dificilmente lhe permitiriam ir além de sugerir que aceitava os ensinamentos do Novo Testamento como verdadeiros porque o seu caráter revelado foi demonstrado, e porque as regras de conduta que transmitem exprimem de forma absolutamente perfeita toda a lei da razão (STRAUSS, 2009, p. 180).
\end{abstract}

$\mathrm{Na}$ verdade, o que Leo Strauss procura, ironicamente ou não, é saber se Locke acreditava no que escrevia, se tinha hesitação quanto a saber se o seu pensamento seria considerado como algo sólido por seus leitores ${ }^{14}$.

Esta crítica não desmerece a obra lockiana. Ao contrário, torna interessante e curioso o iter a ser percorrido para se investigar os argumentos lockianos acerca da origem do governo e dos fundamentos da obediência civil, nas suas relações entre a ética e a política.

\footnotetext{
${ }^{14}$ Leo Strauss, conjugando o pensamento lockiano ao "ensinamento do evangelho" e à "lei da razão", instiga-nos com a observação de que para compreender por que Locke "escreveu os Dois Tratados do Governo, e não uma 'Politique tirée des propres paroles de L'Écriture Sainte', não é necessário pressupor que ele próprio tinha dúvidas a respeito da verdade das duas afirmações mencionadas. [...] Pois, se tinha hesitações deste tipo, foi forçado a tornar o seu ensinamento político, isto é, o ensinamento da lei natural a respeito dos direitos e deveres de governantes e súditos tão independente das Escrituras quanto possível” (STRAUSS, 2009, p. 180).
} 
Deus é uma presença constante em Locke, com implicações na vida terrena e celestial, balizando sua doutrina epistemológica e política. Todavia, todos os seus escritos, em um certo sentido, voltam-se a uma importante questão de "como os homens devem viver", para viverem em harmonia, e não há por que não acreditar na sinceridade de sua intenção, ou seja, que de fato esperava mostrar aos homens "que uma compreensão racional do lugar do homem na natureza exigia que eles vivessem como cristãos" (DUNN, 2003, p. 9). Ademais:

até onde sabemos, em nenhum momento de sua vida Locke duvidou de que os homens conhecem, como uma verdade da experiência, seu dever para com Deus. Tampouco em nenhum momento de sua vida, ele supôs que fosse expor de forma fácil e clara essa convicção (DUNN, 2003, p. 81).

O seu esforço intelectual voltou-se a isso, razão pela qual iniciaremos nosso estudo com algumas reflexões sobre a lei de natureza, pois, segundo Locke, os homens, seres livres e racionais, poderiam bem compreendê-la e se conduzirem sob uma reta moral, tal qual se compreende uma verdade matemática.

A presente assertiva traz elementos importantes para a compreensão da relação entre autoridade política e obediência civil, e talvez até mesmo um modelo pedagógico para o bem viver individual e social. Isso porque, segundo Locke, a liberdade do homem e a liberdade de agir de acordo com a sua própria vontade "baseiam-se no fato de ser ele possuidor de razão, que é capaz de instruí-lo sobre a lei pela qual ele se deverá governar e de fazer com que saiba até que ponto pode dar-se à liberdade de sua própria vontade” (LOCKE, 2005, II, 63).

Nosso autor estabelece um princípio inquestionável: Deus - Lei de Natureza - Razão, e, a partir daí, edifica sua teoria política. No seu entender, os homens, na vida social ou na esfera privada, sujeitam-se aos ditames de determinadas normas. Estas normas são dadas na condição natural por Deus, e os homens as apreendem através da razão. Para Locke, basta observar o mundo a nossa volta, no qual todas as coisas seguem o comando deste decreto divino, para se conseguir reconhecer a existência da lei de natureza, ordenando ou proibindo por si mesma ${ }^{15}$. É esta a premissa que se deve ter em mente na análise das relações entre os homens - tudo segue uma ordem, uma lei--, sejam estas relações de caráter social ou político.

\footnotetext{
15 Locke apresenta "Deus e a Lei de Natureza" como uma verdade pronta no seu ensaio político Segundo Tratado Sobre o Governo. Ao que se percebe, pela leitura dos Ensaios sobre a Lei de Natureza, esta verdade é demonstrável. Neste sentido, o seu raciocínio procura ser "prático e infalível", argumentando que se chega a esta "Verdade" pela "razão e poder de argumentar", marcas distintivas dos homens, os quais, partindo da "percepção das coisas", avançam "para a noção de um criador dessas coisas [...] e afinal concluem e assumem como certo que alguma divindade é autora de todas as coisas. Tão logo se estabelece isso, surge necessariamente a noção de lei universal de natureza capaz de obrigar todos os homens [...]" (LOCKE, 2007, p. 116).
} 
Destarte, na articulação das ideias de Locke, comecemos pela Lei de Natureza, diante da relevância desta no processo - relação autoridade/obediência, pois é ela que irá determinar as regras da moral e da política, proporcionando um melhor entendimento do pacto e da submissão política, delineados no seu mais famoso escrito político, o Segundo Tratado Sobre o Governo Civil.

\subsection{Da Lei de Natureza}

John Locke analisou cuidadosamente a Lei de Natureza no seu escrito Ensaios sobre a Lei de Natureza, um dos seus primeiros, datado de 1663-1664 ${ }^{16}$. Este trabalho, segundo aponta Jean-Fabien Spitz, mostra a lei de natureza como pilar fundamental da filosofia política lockiana, pois Locke traz a ideia de que a autoridade política deve ser concebida e legitimada no contexto da teoria da lei de natureza, com a premissa da existência de uma 'norma de direito' independentemente de qualquer decisão humana, com capacidade para limitar o poder político (SPITZ, 2001: 216).

A lei de natureza, ao que se percebe, é o guia para a conduta humana, seja na órbita privada, seja na esfera pública, disciplinando direitos e deveres, regulando a vontade privada e conduzindo o próprio poder político ${ }^{17}$.

Atribuir à lei de natureza a qualidade de "pilar" do pensamento político lockiano implica enfocar a fundamentação da moralidade como definidora das relações entre os

\footnotetext{
${ }^{16}$ Não se conhece, de forma precisa, a sua intenção em escrever estes Ensaios. Segundo John Dunn, ao tempo em que escreveu os Tracts, seu primeiro ensaio político (1660-1662), Locke mantinha correspondência com seu amigo Gabriel Towerson, na qual faziam considerações sobre as maneiras pelas quais a lei de natureza poderia ser conhecida. De qualquer forma, Dunn enfatiza que, como "Censor" da "Christ Church", Locke estava obrigado a leituras voltadas aos estudos éticos e que, a partir destes Ensaios, é possível expor o desenvolvimento do pensamento lockiano como o desdobramento de uma dialética interna, "analisada num contexto intelectual unitário", sem se pensar em "vácuos" na sua bibliografia (DUNN, 1986, p. 19-20). Seja como for, observa-se que o seu trabalho não esconde a herança estoica e o jusnaturalismo grociano que permeava a época. No entanto, o que deve ficar evidente é que, nestes Ensaios, Locke delineou muito de suas futuras ideias, sobretudo o que nos interessa mais de perto: a relação de poder, tão discutida nos Tratados sobre o Governo Civil.

17 Sobre o tema, lembre-se que J. W. Gough também destacou a relevância da lei de natureza na doutrina lockiana e, inclusive, inicia a sua reflexão sobre a "Filosofia Política de John Locke" observando, já na primeira página, que a "lei de natureza é a pedra fundamental" de sua filosofia política (GOUGH, 1973, p. 1).
} 
homens, inclusive as relações de poder. Extrai-se daí as definições de justo e de injusto, do que se reputará como vício e virtude, pois é "a partir dela que se prescrevem os direitos e os deveres que existem no estado civil. De acordo com Locke é a lei natural em última instância que dota a moral de sentido, o que significa dizer que sem esta noção não haveria distinção entre o bem e o mal", ou, mais ainda, é esta norma objetiva de "essência racional" que definirá “o fundamento e a limitação do poder político" (ALMEIDA, 2006, p. 112).

Pois bem, o estudo lockiano sobre a lei de natureza ocorre da seguinte forma: ${ }^{18}$ nos citados Ensaios, Locke, afirmando categoricamente a existência de uma lei de natureza (Ensaio I), analisa as possibilidades pelas quais se pode conhecê-la - espécies de conhecimento (Ensaios II a V). Nesse particular, refuta que a lei de natureza possa ser conhecida intuitivamente (Ensaio III) ou pelo consenso comum da humanidade (Ensaio V), enfatizando que a lei de natureza é conhecida pela razão atuando sobre os dados da experiência sensorial (Ensaio IV).

Tece reflexões sobre a obrigatoriedade desta (Ensaio VI) ou, melhor dizendo, sobre o porquê da obrigatoriedade da lei, com a consequente e eterna discussão da Justiça Divina, impondo reflexão sobre Deus - legislação e punição. Ainda, pretendendo a atemporalidade desta e cônscio das particularidades "morais" dos indivíduos, faz observações sobre "os modos pelos quais a lei de natureza, não obstante universalmente obrigatória, é modificada por circunstâncias e por relações morais particulares (VII)" (OSTRENSKY, 2007, p. 99).

Por fim, pondo em relevo a sua diretriz ética, Locke vem a refutar que as ações humanas são motivadas ou direcionadas pelos interesses próprios e pelos prazeres pessoais (Ensaio VIII). Aqui, novamente ressalta a característica do indivíduo lockiano: sujeito de obrigações, imbricando ética e política na condução do espaço público ${ }^{19}$.

Locke explica que a Lei de Natureza é “o decreto divino" reconhecível pela luz natural e "que indica o que está e o que não está em conformidade com a natureza racional" (LOCKE, 2007, p. 102). A lei positiva somente obriga aos homens na medida em que a lei

\footnotetext{
${ }^{18}$ Anote-se que uma perfeita análise dos Ensaios Sobre a Lei de Natureza demandaria, por si só, um trabalho à parte, uma pesquisa mais profunda. Todavia, o nosso interesse aqui é apenas ressaltar alguns aspectos da lei de natureza no pensamento de John Locke, a fim de respaldar nossa pesquisa referente ao "embasamento moral" dos "fundamentos da obediência" segundo Locke, seja na esfera pública ou privada.

${ }^{19}$ Assim, na tradição escolástica, com assertivas e refutações às questões, no citado escrito Ensaios sobre a Lei de Natureza, Locke analisa de forma enfática a existência de uma lei de natureza, sustentando razões que autorizam a concluir por uma lei moral universal e obrigatória, traçando parâmetros para seu perfeito conhecimento. Sobretudo, chama a atenção para um conjunto de regras relativas à conduta humana, regras relativas à sociabilidade e que precisam ser reforçadas por intermédio do conhecimento da lei divina.
} 
natural o faça, pois esta é obrigatória a todos por ser da vontade de um legislador onipotente, "e a conhecemos por meio da luz e dos princípios da natureza; não há como o conhecimento dela se ocultar de alguém, a não ser de quem ama a cegueira e a escuridão, e renega a natureza a fim de esquivar-se de seu dever" (Ibid., p. 148).

O seu raciocínio procura ser simples, mas lógico: isso decorre do fato de que Deus é o autor desta lei, e assim o quis para que essa fosse "a regra de nossa vida moral, e Ele a tornou suficientemente conhecida, de modo que a pode compreender quem quer que se disponha a aplicar diligente estudo e a dirigir sua mente ao conhecimento dela" (LOCKE, 2007, p. 147). A Lei de Natureza identifica-se com uma eterna regra de caráter moral, que é dada aos homens pelo decreto de um poder supremo. Ela é conhecida pela luz natural e tem um caráter obrigatório, pois se trata de "ordenação da vontade divina", impondo proibições ou "liberdades" "por si mesma" que serão captadas pelo uso da razão ${ }^{20}$.

Locke afirma a existência de uma "espécie de verdade", cujo conhecimento se pode adquirir com o uso apropriado das faculdades de que o homem é dotado pela própria natureza. Nas palavras do autor, "é possível conhecer a lei de natureza pela própria luz natural”, pois todo homem "dotado de entendimento, razão e percepção sensorial, pode, com a ajuda da natureza e por sua própria sagacidade, buscar e examinar" tal lei (LOCKE, 2007, p. 111).

Nesta trilha, é pelo uso apropriado das faculdades mentais, o qual requer "reflexão, atenção e concentração da mente" (LOCKE, 2007, p. 117), que se chega ao conhecimento da lei de natureza. Segundo Locke, o homem possui como marcos distintivos a razão e o poder de argumentar, devendo primar pelo uso adequado de tais faculdades. Adverte, no entanto, que não é tarefa fácil, pois o uso apropriado das faculdades mentais requer cuidadosa reflexão, sempre sob a orientação da razão. Compara a busca do conhecimento e o exercício da razão à escavação de um filão de ouro "escondido nas entranhas da terra", que requer pacienciosa escavação e o uso do raciocínio para a "construção" de aparatos que auxiliem tal escavação. Para que a labuta não seja inglória, há que se orientar pela razão.

\footnotetext{
${ }^{20}$ Nessa linha, afirma que a obrigatoriedade da Lei de Natureza decorre do fato de ser esta uma norma Daquele que comanda - Justo Poder - e, considerando que somos criados por Deus, Este está acima de tudo e tem autoridade e poder sobre nós, o que nos impõe a submissão à Sua vontade, por suma justiça e pela máxima necessidade. Essa lei que nos obriga, desejo do legislador onipotente, nos é conhecida pela luz e pelos princípios naturais, e toda obrigação implica em um vínculo de consciência, estabelecendo um vínculo mental, "de modo que não o medo da punição, mas a apreensão racional do que é certo coloca-nos sob uma obrigação, proferindo a consciência julgamento sobre a moral e, se somos culpados de um crime, declarando que merecemos punição" (LOCKE, 2007, p. 145-146).
} 
Segundo Locke, são poucos os que se orientam pela razão, deixando-se levar pelos "exemplos dos outros", ou por costumes, ou ainda pela "autoridade dos que julgam sábios e bons", por isso há disparidades de ações dos homens na prática diária. Da mesma forma, poucos se dispõem a "conhecer" a lei de natureza, mas disso não se segue "que não se possa conhecer a lei de natureza pela luz natural porque há apenas uns poucos, não corrompidos pelo vício ou descuidadamente indiferentes, que fazem uso apropriado dessa luz" (LOCKE, 2007, p. 118) ${ }^{21}$.

Locke demonstrou grande preocupação com o perfeito entendimento da Lei de Natureza. Tinha consciência de que era conhecida sob vários nomes ou descrições e que, inclusive, confundiam-na com "costumes" ou "consenso geral". A sua preocupação foi observada por John W. Yolton. Segundo este autor, além de ser equiparada ao “"bem moral ou virtude que os filósofos de tempos idos' buscavam (por exemplo, os estóicos)",

a lei de natureza também foi identificada com a "razão correta, que é reivindicada por todo aquele que se considera um ser humano" (p.111). Nesse contexto a razão não é faculdade de raciocinar, mas antes, "um certo princípio definido de ação, do qual promana toda a virtude e tudo o que se faz necessário para a adequada formação moral” (YOLTON, 1996, p. 145).

Yolton observa também que muitos se referem a "uma lei de natureza" como uma lei que se pode detectar tão-somente pela luz plantada em nós pela natureza, à qual cada um se mostra obediente em decorrência de um princípio, de uma obrigação, "e é essa a regra de viver de acordo com a natureza que os estóicos tanto enfatizam" (LOCKE, 2007, p. 102). Na verdade, a preocupação de Locke é demonstrar que há uma regra eterna e imutável a impor obrigação de conduta a todos, propiciando a vida pública ou privada em harmonia. Logo, também importante é a distinção entre a lei, "designada por tais nomes", do direito natural, pois o direito funda-se "no fato de termos o livre uso de algo, enquanto a lei é o que ordena ou proíbe fazer certa coisa" (LOCKE, 2007, p. 102). Aqui, evidencia-se bem o indivíduo lockiano, um sujeito de obrigações, mais do que propriamente de direitos, a fim de cumprir a lei natural: preservar-se e preservar a toda a humanidade.

\footnotetext{
${ }^{21}$ É interessante a ênfase dada à razão e ao poder de argumentar, dados diferenciadores do homem trazidos por Locke, para ressaltar o "uso apropriado da razão" no ou para o bem viver, consignando que "a natureza e as propriedades das figuras e números parecem óbvias e, sem dúvida, conhecíveis pela luz da natureza; porém, disso não se segue que quem estiver da posse das faculdades mentais se converterá em geômetra ou conhecerá por completo a ciência da aritmética. Para que alguém consiga encontrar um caminho das coisas perceptíveis e óbvias à sua natureza oculta, é necessária cuidadosa reflexão, pensamento e atenção da mente" (LOCKE, 2007, p. 117).
} 
Locke, ao tratar da Lei de Natureza, regra de conduta moral universal que impõe deveres aos homens, segue a trilha da "tradição tomista do jusnaturalismo", a saber:

esboça o conteúdo da lei natural considerando a constituição do homem e seus fins. Assim, pode ele determinar nossos deveres em relação a Deus, ao próximo e a nós mesmos. Devemos louvar a Deus e conhecer a sua criação, pois ele a criou para sua glória, entrar em sociedade com outrem, pois somos animais sociais e falantes, e enfim conservar-nos a nós mesmos. A lei natural é assim deduzida da consideração dos fatos, especialmente dos fatos da natureza humana. É o que Locke tinha em vista ao dizer que a lei natural é conhecida pela razão a partir da experiência sensível (MICHAUD, 1991, p. 25).

A imbricação entre lei de natureza, razão e conhecimento passa a ter especial relevância no pensamento lockiano. Tanto que nos Ensaios sobre a Lei de Natureza, bem como no Segundo Tratado, Locke se refere à lei de natureza como a "lei da razão" ou como "sendo a própria razão" (v.g. LOCKE, 2005, II, 6). Atento às várias e possíveis interpretações que os escritos lockianos ensejam, Rolf Nelson Kuntz adverte que:

Nos Ensaios sobre a Lei de Natureza, um trabalho de 1660, parte da argumentação enfatiza a origem divina dos mandamentos naturais. Dessa origem decorre, segundo Locke, seu caráter vinculante. Mas como se pode conhecer a norma e a obrigação? Pelo emprego das faculdades naturais do homem - esta é a resposta. A referência à razão, contida tanto no Segundo Tratado quanto nos Ensaios, pode levar o leitor a um equívoco. A identificação entre razão e lei natural, presente nos dois livros, tem origem, claramente, numa noção ciceroniana convertida em lugar comum. Não se trata, neste caso, da faculdade do entendimento humano, mas da recta ratio, isto é, de "certos princípios de ação definidos dos quais decorrem todas as virtudes e tudo que é necessário para a adequada conformação moral" (ELN, p. 111). Não se deve confundir esses princípios com meros ditados da razão. A lei natural, na concepção lockiana, tem outro tipo de objetividade, porque provém de Deus [...]" (KUNTZ, 2004, p. 102-103).

De fato, Locke se refere à razão como faculdade, na medida em que impõe a reflexão - abstração - para que o homem possa conhecer seus desígnios e agir de acordo com a reta razão, quando se refere a "aplicar diligente estudo" ou à necessidade de se fazer "uso apropriado das faculdades mentais" que "requer reflexão e orientação pela razão" (LOCKE, 2007, p. 117).

Todavia, ao se referir à lei de natureza como a própria razão, obviamente, refere-se ao “código de moral”, princípios norteadores da conduta humana - reta razão - regra e medida comum emanados de Deus (LOCKE, 2005, II, 11). O que Locke pretende é estabelecer que se trata de algo não suscetível deste ou daquele entendimento, pois é a Vontade de Deus presente no "espírito do homem" (LOCKE, 2007, p. 102 e 2005, II, 136). A razão é o instrumento pelo 
qual o homem diligente aproxima-se da lei de natureza: "a razão quando consultada" mostra aos homens os mandamentos divinos para o bem viver em comunidade, seja esta natural ou política.

O importante é que, de certa forma, Locke busca apartar-se da temática da moral como construção humana, deixando-a longe de algo condicionado pelo tempo e pelo espaço. Tal posicionamento deve-se ao reconhecimento da presença e da existência de uma divindade suprema, algo marcante nos seus escritos, pois para Locke Deus se faz presente em todos os lugares, revelando-se, sobretudo, "no curso fixo da natureza", como se depreende do nascer do sol e do desabrochar de uma flor.

Locke procura ressaltar que a natureza apresenta leis válidas e fixas que operam por si mesmas, sob o comando de Deus, o qual

estabeleceu limites até mesmo para o mar indômito e prescreveu a cada espécie de planta a maneira e os períodos de germinação e crescimento; é em obediência a Sua vontade que todos os seres vivos possuem leis próprias de nascimento e vida; e nada há de tão instável, tão incerto em toda essa constituição de coisas que não admita leis válidas e fixas de operação apropriadas à sua natureza [...] (LOCKE, 2007, p. 100-101).

Para Locke, a Fé e a Razão indicam que tudo teria uma ordem, uma lei a seguir naturalmente $^{22}$. De forma precisa, existiria um curso fixo da natureza, do qual não há que se aceitar que o homem estivesse "fora" do plano de "Deum Optimum Maximum", que preside o mundo. Assim, "parece justo investigar se só o homem veio ao mundo inteiramente isento de qualquer lei aplicável a si, sem um plano, norma ou padrão para sua vida” (LOCKE, 2007, p. 101).

\footnotetext{
${ }^{22}$ Lei de Natureza, Deus e a Razão, pontos extremamente intrigantes na construção da moralidade lockiana. Locke não estabelece ao certo uma hierarquia de argumentos para a assimilação, para o respeito e devido acatamento (tornar realizável) da lei de natureza. Ora funda-se em Deus, ora na razão. Paira a discussão: Deus argumento ou instrumento no seu pensamento. Deus é presença forte, mas não se descuida que Locke traz no cerne de sua discussão o legado estóico do homem como criatura racional e com um lugar especial entre os demais seres. A razão, neste prisma, vem a ser o elemento preponderante no fundamento da lei de natureza, pois o elemento racional é a chave para a unidade e coesão entre os seres. Na linha do estoicismo, a razão é o fundamento da sociedade e do Direito, pois como observa Alberto Ribeiro G Barros, "as normas estabelecidas pelos homens para viver em sociedade podiam ser julgadas a partir de um princípio designado pelos estóicos de lei natural. Era uma lei não instituída, pura exigência da razão, também chamada lei divina ou eterna, donde as leis humanas tiravam seu fundamento. Refletia a justa razão, essa razão suprema imanente à natureza que regulava o curso dos astros e que governava todo o universo" (BARROS, 2007, p. 44). Locke, nesta linha concede que tudo é governado por uma lei racional que pode ser descoberta pelo homem, pelo uso da razão e, que a lei de natureza é o fundamento da comunidade política e da lei civil (LOCKE, 2002, p. 118). Todavia, traz um plus: "Deus enim legis" e, como Autor desta lei, torna conhecida a Sua Vontade que será a regra da vida moral dos homens (LOCKE, 2002, p. 186). Esta questão será retomada ao final do presente trabalho.
} 
Para fundamentar sua teoria da moralidade (ética) e sua teoria política, a seu ver imbricadas, Locke sustenta que as relações entre os homens devem ocorrer sob a lei de natureza, que não é “criada pela sociedade, é uma lei espontânea, revelada pela conjugação da experiência e da razão. Esta lei dá limites ao homem ordenando suas ações, dando-lhe preceitos morais, apoiando o cumprimento dos pactos e facilitando a vida em sociedade" (MULLER, 2005, p. 49). Para ele, uma vez abolida a lei de natureza entre os homens, "a um só tempo baniremos da humanidade todo o corpo político, toda a autoridade, ordem e amizade entre os homens" (LOCKE, 2007, p. 148) ${ }^{23}$.

Ora, a demonstrabilidade das certezas morais desafia a história do homem, e John Locke, herdeiro da neoescolástica, afirma a lei de natureza - lei moral universal - como um preceito que delineia e fundamenta o poder político. A importância que imputou à lei de natureza impõe o reconhecimento de uma moralidade atemporal e sem fronteiras. Vale afirmar, de forma peculiar leva à reflexão da obrigatoriedade da lei de natureza, conhecível sob a luz da razão, imutável e universal, diga-se sempre: substrato de seu pensamento político, pois nos Dois Tratados sobre o Governo assinala que a lei de natureza é mais clara do que a lei positiva (LOCKE, 2005, II, 12) e que a legitimidade desta depende de sua consonância com a eterna e imutável lei de natureza.

As reflexões sobre a obrigatoriedade da lei de natureza (Ensaio VI), precisamente a necessidade de sua obrigatoriedade, põem em relevo a relação entre poder e obediência, face à análise do que se pode entender por obrigação, bem como do alcance da expressão estar obrigado. De forma mais específica, tentam estabelecer o bem viver ou o como viver sob o desígnio do Criador, e entender o que este Ser Sábio, Onisciente e Onipresente obriga ou impõe ao homem. Desta relação entre a criatura e o Criador é que se extraem os parâmetros da relação entre todas as criaturas, precisamente, de como um homem deve se relacionar com o outro, todos criados à “imagem e semelhança de Deus". Da esfera das relações privadas, chega-se às relações na esfera pública, com parâmetros delineados no que toca às obrigações dos homens livres e iguais.

\footnotetext{
${ }^{23}$ Locke tem um cuidado especial em traçar condicionamentos à boa convivência. Por exemplo: nas relações habituais entre os homens e na vida comum, quem é obrigado a manter conversa sobre seu vizinho e intrometerse em casos de outras pessoas? "Ninguém, sem dúvida. Qualquer um pode, sem causar dano, falar ou ficar em silêncio. No entanto, se por acaso alguém quiser falar sobre outra pessoa, a lei de natureza certamente prescreve que a conversa seja sincera e amistosa, e que se digam coisas que não causem dano à reputação e ao caráter de outra pessoa" (LOCKE, 2007, p. 152). Nosso autor, dessa forma, nos fornece os parâmetros de sua Ética. A par de ter se tornado o "teórico" do liberalismo-individualismo, apregoava, a seu modo e a seu tempo, com muita ênfase, a boa moral ou virtude, quase como uma "aspiração de uma possível solidariedade cristã", condição necessária ao convívio social.
} 
Nos Ensaios, percebe-se a preocupação de Locke em definir o vínculo pelo qual alguém está ou pode se considerar obrigado a algo. Isso deixa entrever a base da relação de poder, pois a noção de lei implica na noção de obrigação e de dever, a existência de uma autoridade e estabelece tudo o que for necessário para criar uma obrigação, inclusive com recompensas e punição.

Nosso autor toma como referência o conceito jurídico de obrigação, no qual se faz presente uma relação de poder "- autoridade-lei e punição -". Enfatiza que o "vínculo da lei de natureza impõe o cumprimento de uma obrigação natural", precisamente, desempenha "a tarefa que cabe a um homem realizar em razão de sua própria natureza, ou então se submeter à punição devida pelo crime cometido" (LOCKE, 2007, p. 144).

Locke esclarece que esse vínculo decorre de uma relação de poder, remetendo-nos à presença de Deus, poder superior, que possui direito sobre nós, Suas criaturas. Assim, toda

obrigação retrocede a Deus e estamos obrigados a nos mostrar obedientes à autoridade de Sua vontade porque tanto nossa existência como nosso trabalho dependem de Sua vontade, uma vez que recebemos Dele, e por isso estamos obrigados a observar os limites que Ele prescreve; mais ainda, é razoável fazermos o que apraz a um Ser onisciente e sapientíssimo (LOCKE, 2007, p. 145).

Assim, a decorrência lógica da vontade de um poder superior é a obediência, é a conformidade das ações de acordo com a regra preestabelecida por aquele que detém o poder de império. Isso porque, segundo Locke, o vínculo resultante desse poder impõe o compromisso da obediência, obrigação de fazer ou deixar de fazer segundo a vontade superior, e o compromisso para com a punição, consequência da desobediência. Punição necessária, sem a qual a lei seria inócua.

Locke preocupa-se muito com a natureza e a fonte da obrigatoriedade (liame obrigatório) da lei. Descarta que a obrigatoriedade da lei - seu cumprimento - esteja na "preservação de si mesmo", sob pena de reduzir a virtude a uma simples "conveniência" 24. No entanto, não descuida que a razão mostra que certos comportamentos são necessários para

\footnotetext{
${ }^{24}$ No Segundo Tratado Locke enfatiza que "cada um está obrigado a preservar-se, e não abandonar sua posição por vontade própria; logo, pela mesma razão, quando sua própria preservação não estiver em jogo, cada um deve, tanto quanto puder, preservar o resto da humanidade [...]" (LOCKE, 2005, II, 6). Assim, a lei de natureza inclui o dever de preservar a humanidade e "por consequência a sociedade", pois "cada um tem o dever de preservar a humanidade, e como o homem não pode existir sem os outros, segue-se o dever de preservar a sociedade" (ALMEIDA, 2006, p. 114). Sobre esta questão, ver a análise de "the preservation of Mankind", feita por James Tully em A Discourse on Property, inclusive com a consequente propensão/necessidade do homem a ingressar em sociedade (TULLY, 1982, p. 45-50).
} 
a preservação do próprio homem. Até porque o homem, como artefato de Deus, deve não só velar por si, como pela própria humanidade, ou seja, por toda a criação, pois segundo Locke, Deus nos concedeu a vida e somente Ele a pode tirar.

O pensamento lockiano entrelaça obrigatoriedade com legitimidade: afirma que a lei de natureza é obrigatória por si mesma e por sua força intrínseca, considerando que Deus é o autor desta lei e que a tornou conhecida àquele que se dispõe a estudar e refletir sobre a mesma, sendo verdadeira regra de moralidade, necessária à relação entre os homens. Busca aqui não só a submissão a mesma, mas sua aceitação-aprovação como única forma para a harmonia social: preservação da espécie ${ }^{25}$.

John Locke expressa a lei como "vontade do legislador", sendo que o reconhecimento desta lei de natureza decorre da própria ordem das coisas: "ordem da natureza e dos fins das coisas". Ao sustentar a obrigatoriedade da lei em decorrência de uma vontade superior, Locke assume posições, diga-se, voluntaristas: a lei nos obriga, sendo a obrigação o "compromisso ao qual a lei submete", ou seja, a obrigação decorre de "um poder acima de nós", ao qual devemos obedecer, ou então nos sujeitaremos a sofrer castigos. Não obstante, é certo que Locke "admite que nem tudo é questão de coerção. A autoridade tem diversas fontes (o poder

\footnotetext{
${ }^{25}$ Aqui prepara e extrai o fundamento da obrigatoriedade da lei civil, que deverá estar de acordo coma lei natural, para a sua legitimidade. Locke imbrica legalidade e legitimidade, resumindo que, "como nada mais é necessário para impor uma obrigação, a não ser a autoridade e o legítimo poder de quem comanda, além da divulgação de sua vontade, ninguém pode duvidar de que a lei de natureza seja obrigatória a todos os homens" (LOCKE, 2007, p. 147). Observa-se que Locke não utiliza a expressão legitimidade, referindo-se a Deus como a autoridade que tem o poder de direito para impor obrigações aos homens que estão sob o seu comando: poder natural de legislar (LOCKE, 2002, p 186). Da mesma forma, no estado civil, os homens ao ingressarem em sociedade e instituírem o poder legislativo, este tem o poder de direito (e legitimo, dado a aprovação de todos) para impor leis. Não somente as traduções dos textos de Locke usam a expressão legitimidade, mas é corrente, principalmente no meio jurídico ou na linguagem política, buscar o paralelismo das duas expressões a justificar a boa existência da lei (aspecto forma, material e social) e impor a obediência. Sobre as expressões legalidade e legitimidade, Norberto Bobbio, observa que: "Na linguagem política, entende-se por legalidade um atributo e um requisito do poder, daí dizer-se que um poder é legal ou age legalmente ou tem o timbre da legalidade quando é exercido no âmbito ou de conformidade com leis estabelecidas ou pelo menos aceitas. Embora nem sempre se faça distinção, no uso comum e muitas vezes até no uso técnico, entre legalidade e legitimidade, costuma-se falar em legalidade quando se trata do exercício do poder e em legitimidade quando se trata de sua qualidade legal: o poder legítimo é um poder cuja titulação se encontra alicerçada juridicamente; o poder legal é um poder que está sendo exercido de conformidade com as leis. O contrário de um poder legítimo é um poder de fato; o contrário de um poder legal é um poder arbitrário" (BOBBIO, 1999, p. 674). Na linguagem comum, a expressão legitimidade liga-se a noção de justiça ou racionalidade. De toda forma, o termo legitimidade "designa, ao mesmo tempo, uma situação e um valor de convivência social (...) a aceitação do Estado por um segmento relevante da população; o valor é o consenso livremente manifestado por uma comunidade de homens autônomos e conscientes" (BOBBIO, 1999, p. 678). Locke, de fato não fala expressamente em poder legítimo, mas contrapõe "poder arbitrário" ao "poder de direito", discorre sobre a "força sem direito" ao abordar a dissolução do governo (II, 232), que denominamos de "governo ilegítimo" (tema este que será analisado no capítulo três). Sobretudo, é corrente na sua fala a necessidade do "consentimento e da aprovação" para o exercício do poder, para a obrigatoriedade da submissão, para a legitimidade da relação autoridade e obediência.
} 
do Criador, a transmissão, o contrato), nem sempre se obedece por medo do castigo: a obrigação pode empenhar a consciência, que apreende então, racionalmente, o que é direito" (MICHAUD, 1991, p. 25).

Locke procura, então, discorrer sobre a obrigação como algo ligado à escolha, ou melhor, ao saber escolher, ao bem agir, imbricado com a virtude, porque, racionalmente, o homem pode perceber suas obrigações naturais. Todavia, Locke adverte que a lei de natureza pode não ser conhecida por todos, pois seu conhecimento exige perspicácia e raciocínio e, embora todos sejam, por natureza, dotados de razão, alguns não fazem uso desta luz, preferindo a escuridão. Aqui Locke evidencia a liberdade de escolha do ser humano e prega a necessidade do bem agir, ou seja, o agir diligente e laborioso, condenando a preguiça mental, pois "nem mesmo o sol revelará a um homem o caminho a trilhar, se este não abrir os olhos e se preparar para a viagem" (LOCKE, 2007, p. 105) ${ }^{26}$.

No que se refere à natureza da obrigação e à explicação da "força da obrigação", a teoria lockiana se aproxima de "um meio termo" entre as teorias voluntarista e racionalista, pois Locke mescla o caráter obrigatório da lei aceito pela fé, decorrência da aquiescência de sua origem divina (lei de natureza é decreto divino) e, ao mesmo tempo, não se descuida do fato de que são "normas" captadas pela razão, obrigando o homem pelo fato de ser racional (a lei de natureza é conhecida pela razão). ${ }^{27}$

Ives Michaud observa que Locke "afirma ao mesmo tempo que a lei natural obriga e que essa obrigação permanece globalmente em harmonia com nossos fins", pois a lei de natureza é obrigatória por ser a expressão de Deus, e o seu reconhecimento intelectual vem a "partir da ordem da natureza e dos fins das coisas", e conclui que Locke

[...] permanece dividido entre uma concepção voluntarista nominalista da lei natural e uma posição ontológica intelectualista. Cada uma delas permite explicar a força da obrigação: uma pela submissão à vontade superior detentora das sanções do além, a outra pelo reconhecimento intelectual da ordem das coisas. A primeira ameaça abalar o aspecto natural e racional da lei "natural", a segunda enfraquece a pressão da lei, ao mesmo tempo em que a torna mais "natural". Progressivamente, Locke parece inclinar-se para a segunda interpretação, afastando-se da de Hobbes, mais tomista e mais próxima do platonista de Cambridge. Como dizia Ralph Cudworth, "as

\footnotetext{
${ }^{26}$ Locke quer mostrar, avidamente, que não há como deixar de conhecer a lei de natureza. Isso em função do liame entre a natureza racional dos homens e a própria lei de natureza. $\mathrm{Na}$ sua exposição, enfatizando a obrigatoriedade desta, afirma que a "sua necessidade decorre da natureza do homem, como as propriedades do triângulo dependem de seu conceito. Da lei como expressão de uma vontade todo-poderosa, passou-se à lei como natureza das coisas" (MICHAUD, 1991, p. 25).

${ }^{27}$ Nesta linha, ver Tully (1982, p. 40-42).
} 
coisas são o que são não por vontade, mas por natureza". O inconveniente é que essa concepção requer conhecimento da natureza e da ordem das coisas, dos argumentos cosmológicos e teleológicos convincentes. Numa época em que o desenvolvimento das ciências questionava radicalmente a imagem tradicional de um mundo fechado e ordenado, tal abordagem levava inevitavelmente à questão da nossa capacidade de conhecimento (MICHAUD, 1991, p. 25).

Rolf Nelson Kuntz, na análise da autoridade da Lei de Natureza nas relações humanas, observa que, na medida em que Locke afirma que a própria lei civil deve estar de acordo com a lei natural (e sendo esta a vontade de Deus), necessariamente, Deus seria o "elemento fundante" não só da lei de natureza como também da lei civil ${ }^{28}$.

Nesse enfoque, além do caráter "autoritário" desta (que o colocaria numa "armadilha conceitual" por oferecer uma "concepção de lei hobbesiana"), há que se permitir afirmar que Locke apresenta uma concepção voluntarista da lei, pois "a norma expressa a vontade, ou comando, de uma entidade superior. Essa entidade, além de tudo, é personificada” (KUNTZ, 2004, p. 105)

A presença de Deus (verdade não questionável), que tem poder e domínio sobre nossas ações, e a "consciência cristã" da finalidade de todas as coisas criadas por Ele garantem a autoridade, a força vinculante da lei de natureza, pois como explica Rolf Kuntz:

a definição inclui a punição como elemento essencial. Uma lei sem punição, argumenta Locke, não tem propósito, embora o vínculo da obrigação decorra não do temor, mas da apreensão racional do que é correto (ELN, p. 185). Se o autor aceita essas condições, a idéia de lei natural impõe a afirmação da existência de uma divindade, ou algo semelhante (?), dotada de vontade legisladora. Locke não comete, é claro, a grosseria de um raciocínio circular. Há uma "demonstração" da existência de Deus e isso garante a sustentação do edifício. A lei natural, nesse caso, só se distingue da lei positiva divina por ser conhecida por meio da luz de natureza, isto é, da razão, e não pela revelação (ELN, p. 187)" (KUNTZ, 2004, p. 105).

Locke mescla fé e razão no que toca à Lei de Natureza: obedecemos por ser a Vontade do Grande Legislador - Deus -, e para termos uma vida melhor no além (medo e recompensa). E obedecemos por ser uma opção racional - única forma para o bem viver no

\footnotetext{
${ }^{28}$ Leo Strauss afirma que Locke se refere à lei natural como se fosse uma "lei no sentido estrito do termo. A lei natural impõe deveres perfeitos ao homem enquanto homem, quer ele viva no estado de natureza, quer na sociedade civil. [...] Locke considera que é inteiramente possível que a lei natural ou lei moral seja elevada ao estatuto de uma ciência demonstrativa. [...] Assim, o homem tornar-se-ia capaz de elaborar 'a partir dos princípios da razão, um corpo de doutrina moral, que seria de modo demonstrativo a lei natural e ensinaria todos os deveres da vida' [...] um 'código' que nos dá a lei natural 'integral'. Esse código conteria, entre outras coisas, a lei penal natural" (STRAUSS, 2009, p. 174).
} 
presente e no futuro terrenos, pois este é o alcance da máxima da lei de natureza: preservar-se e preservar a humanidade. Mas talvez a opção racional não nos leve, por si só, à amizade e à harmonia. Assim, Locke procura trabalhar a "consciência humana", apontar um código de regras morais - reta razão - para um viver melhor no presente e que, segundo a sua visão cristã, também assegurará uma vida melhor no além.

Face à sua capital importância na doutrina política lockiana, os Ensaios mereceriam uma melhor análise. Mas, considerando os apontamentos até aqui expostos e o nosso objeto de investigação - a obediência civil, no contexto de uma relação sociável de confiança, portanto com base ética -, destacamos por ora, de forma sucinta, os cinco argumentos pelos quais Locke procura "comprovar a existência da lei de natureza", exarados no Primeiro Ensaio $^{29}$.

Neste, ele faz a seguinte pergunta: "Existe uma regra da moralidade ou de natureza que nos seja dada?". A esta questão responde: "Sim". Os argumentos articulados na sua resposta mostram a chave para uma consciência ética humana.

Inicialmente, afirma que, por ser o homem um ser racional, "apreende a lei natural através da razão", ou seja, "está na natureza do homem agir com a razão". A sua assertiva respalda-se em Aristóteles: "a função específica do homem é o exercício ativo das faculdades da mente de acordo com o princípio racional”. Lembra que, na Ethica Nichomachea, Aristóteles, após demonstrar,

por vários exemplos, que existe um tipo específico de obra que cada coisa está designada a realizar, ele tentou descobrir o que vem a ser isso também no caso de um ser humano [...] no final ele concluiu corretamente que a função própria do homem é agir em conformidade com a razão, de tal modo que o homem deve, necessariamente, fazer o que a razão prescreve (LOCKE, 2007, p. 103).

O segundo argumento vem a ser a justa razão, na verdade a própria consciência humana como autoridade interna. Citando Juvenal (Sátiras), Locke sustenta que "ninguém que pratica uma ação iníqua é absolvido de seu próprio julgamento”, ou seja, o autojulgamento que avalia o certo ou errado, a sentença "que cada um profere sobre si" constitui o testemunho da existência da lei de natureza. Segundo Locke, o homem recrimina "uma atitude porque consegue apreender a lei natural, através da razão; não é apenas da razão

\footnotetext{
${ }^{29}$ Isso porque possuem ligação direta com o "pacto societatis" e a possível sujeição política, num contexto de confiabilidade.
} 
dedutiva, mas sim do uso de certos princípios definidos de ação do qual nascem as virtudes e o modelo da moral" (MULLER, 2005, p. 23) ${ }^{30}$.

Em seguida, no terceiro argumento, Locke explica que a compreensão da lei de natureza "deriva da mesma constituição deste mundo", advém da própria estrutura do universo. Todo universo é governado por uma lei, tudo que existe "cumpre o que lhe foi prescrito pela lei de acordo com sua natureza". Da mesma forma, como anteriormente afirmado, o homem não estaria "fora desta ordem", ao contrário, segue esta lei e tem sua conduta regulamentada por ela. Na esteira de São Tomás de Aquino, o autor aduz que "tudo que acontece nas coisas criadas é matéria da lei eterna" e que nada "se desvia nem sequer uma polegada do que a lei lhe prescreveu", concluindo com Hipócrates: "todas as coisas, pequenas ou grandes, cumprem a tarefa que o destino determinou" (LOCKE, 2007, p. 107).

No quarto argumento, Locke afirma que a lei de natureza é o sustentáculo da sociedade política e das leis civis, bem como do cumprimento dos pactos entre os homens ${ }^{31}$. As leis civis são obrigatórias por força da lei de natureza que ordena a conservação da paz pública e a obediência aos superiores, como condição necessária para a própria existência humana.

Locke argumenta que sem as leis de natureza o homem agiria buscando utilidade e não virtude. Assim, há a necessidade da lei para "distinguir o bem e o mal - falta e culpa -, com seus inevitáveis consectários - prêmio e castigos -, pautando nossos comportamentos, educando os homens para o convívio social. Ora, caso assim não fosse, tudo estaria à mercê do arbítrio do homem, pois não existiria nada exigindo a "conduta obediente" e o homem "não estaria obrigado a nada, a não ser àquilo a que um impulso cego e desregrado pudesse

\footnotetext{
${ }^{30}$ Nesse particular, Locke pode nos apontar uma noção "interna de justiça", proporcionado pela lei de natureza em função do "dever de preservar toda a humanidade". Assim, o "ato de matar" é plausível em raríssimas situações (autodefesa e defesa da humanidade), pois somente aqueles que "renunciam à razão" cometem desatinos. A máxima, então, que se extrai da lei de natureza é: "aquele que derramar o sangue do homem, pelo homem terá o seu sangue derramado". E, para concluir, cita a passagem bíblica envolvendo o desatino de Caim: "Caim estava tão plenamente convicto de que todos assim tinham o direito de destruir um criminoso que, após o assassínio de seu irmão, exclamou 'Aquele que me encontrar me matará', tão claramente estava isso inscrito no coração dos homens" (LOCKE, 2005, II, 11). Há que se lembrar que a Lei de Natureza é a vontade divina e que, através da razão e do conhecimento sensível, o homem a compreenderá naturalmente; sendo assim, no caso daqueles que não utilizam "esta faculdade", suas "opiniões" não são oriundas do "juízo, ou a consequência da razão, mas efeitos do acaso numa mente aberta a todas as aventuras, sem escolha e sem direç̧ão" (LOCKE, 2008, p. 930).

${ }^{31}$ Para Locke, as sociedades políticas repousam em dois fatores: primeiro, a escolha da constituição do Estado e da forma de governo e, segundo, o cumprimento dos pactos. A lei de natureza fornece o substrato moral à obediência aos pactos, como também ao bem agir dos governantes, tornando viável o corpo político, pois governo e governados agirão voltados ao mesmo fim: bem público. Ausente o comando da lei de natureza, ou seja, sem este substrato moral, os homens agiriam movidos pelo interesse próprio, sendo inviável o convívio social e a união entre os homens (LOCKE, 2007, p. 108).
} 
por acaso se agarrar. Os termos "integridade" e "virtuoso" perderiam sentido e desapareceriam, ou nada seriam além de nomes vazios" (LOCKE, 2007, p. 109).

Face ao que se pode extrair dos Ensaios e, em particular, desses cincos argumentos, John Locke pensa a ordem política confirmando a liberdade e a igualdade da humanidade, delineando uma sociedade política norteada pela lei natural, que traz em si os preceitos de regras morais (e políticas) que definem a conduta dos indivíduos.

Os preceitos da lei natureza estão voltados a estabelecer "as fundações das virtudes morais e fazem o possível para inculcar sentimentos de respeito e amor pela divindade, obediência a superiores, fidelidade ao manter promessas e falar a verdade, brandura e pureza de caráter, disposição amistosa e todas as outras virtudes" (LOCKE, 2007, p. 113) ${ }^{32}$.

Para pensar a sociedade, o "pactum societatis" - a relação entre os homens -, há que se pressupor uma noção de justiça natural universal, corolário da lei de natureza, válida para toda humanidade. De acordo com Locke, é inerente à natureza humana a noção de igualdade, razão pela qual "ninguém deveria prejudicar a outrem em sua vida, saúde, liberdade ou posses" (LOCKE, 2005, II, 6).

A relação entre governante e governado, bem como entre os homens em particular, segundo Locke, seria verdadeiramente impossível sem a lei de natureza, a saber:

Decerto, leis civis positivas não são obrigatórias por sua própria natureza, força ou de algum outro modo senão em virtude da lei de natureza, que ordena a obediência aos superiores e a conservação da paz pública. Assim, ausente tal lei, talvez os governantes consigam, mediante o emprego da força e a ajuda das armas, compelir a multidão à obediência; todavia, impor-lhe uma obrigação já não o conseguem (LOCKE, 2007, p. 108).

O pensamento de Locke relativo ao poder civil nos transmite não um conceito de obediência civil, mas sim um processo participativo, longe de uma simples sujeição política. Há uma dinâmica na sua fala sobre a relação entre autoridade e obediência, uma dinâmica no que possa ou venha a ser essa relação ${ }^{33}$. Nota-se, nesse processo, a construção ou tentativa de

\footnotetext{
${ }^{32}$ Locke, prenunciando sua linha diretriz de "um possível sistema educacional", adverte que somente através da educação bem refletida e orientada é que se podem estabelecer as "fundações morais", sendo devido um cuidado especial e diligente aos jovens para preencher de amor e conhecimento da verdade suas delicadas almas. Esse cuidado é imperioso "para que as almas humanas não se tornem demasiado propensas ao prazer, ou sejam, conquistadas pelos atrativos do corpo, ou extraviadas por maus exemplos que acontecem em todos os lugares, $\mathrm{e}$ assim façam pouco caso dos preceitos mais sadios da razão" (LOCKE, 2007, p. 113).

${ }^{33}$ No entanto, e isso é o que se deseja concluir, este processo político participativo na relação entre governo e governados requer uma certa consciência do homem enquanto criatura racional e sensível, o que implica um certo grau de conhecimento e, por sua vez, torna a formação - educação - do homem algo extremamente importante.
} 
construção de uma moralidade, tornando ética e política indissociáveis. Sobretudo, vale lembrar, no Ensaio VIII, Locke indaga: "A base da lei de natureza é o interesse próprio de cada homem?" A essa questão, categoricamente, responde: "Não". Para Locke, o essencial é que todos tenham consciência de que seu agir deve voltar-se para o bem da "comunidade e de toda a humanidade", e não para vantagens pessoais. Esta sua afirmação apresenta o princípio que mapeia as relações entre os homens:

Alguns adquiriram imortalidade por suas obras, alguns por seus estudos, alguns por sua morte, nenhum conseguiu grandeza ou excelência sendo indolente ou ganancioso (LOCKE, 2007, p. 160).

Mais uma vez, o fundo ético de sua concepção do agir humano - o homem não busca seu próprio interesse - deve balizar o direito à preservação de si com o dever de preservação da humanidade. A implicação direta desta regra é que cada homem agirá na confiança de que o outro age da mesma forma.

Vê-se assim que, antes mesmo de seu escrito político Dois Tratados Sobre o Governo, Locke já asseverava que o elo da sociedade civil, sob a matriz da lei natural, na imbricação entre poder-autoridade e obediência, traduz-se na confiança ${ }^{34}$.

A conclusão a que se chega é a de que a relação governo-governado não deve decorrer do medo, da coação dos poderosos, pois isso é inerente à autoridade dos tiranos, dos piratas e dos ladrões, mas se deve obedecer por causa da consciência,

porque um rei exerce domínio sobre nós por direito; isto é, porque a lei de natureza decreta que príncipes e legislador, ou um superior - seja lá qual for o nome pelo qual chamemos -, deve ser obedecido. Por isso, a força obrigatória da lei civil depende da lei natural; e não somos tanto coagidos a prestar obediência ao magistrado pelo poder da lei civil como obrigados à obediência por direito natural (LOCKE, 2007, p. 148-149).

Assim, Locke sustenta que os homens nascem livres e iguais por natureza, sob a égide da Lei de Natureza, e concebe a sociedade política e o governo apenas quando formados pelo consentimento. Estas assertivas mestras no seu pensamento político, aliadas à sua tese da "já

\footnotetext{
${ }^{34}$ Locke, no decorrer de sua trajetória, "sempre acreditou numa ordem divina do universo" e, em escritos posteriores sempre manteve "o essencial das afirmações dos Ensaios sobre a lei natural, embora seja menos claro sobre a maneira de demonstrá-la", talvez, porque haja uma dificuldade relativa aos meios de conhecê-la. Ainda, observando as "capacidades humanas", descobre-se que "os homens são pouco inclinados para a razão e contornam a obrigação da lei natural, quando não a ignoram pura e simplesmente" (MICHAUD, 1991, p. 26). Locke não mais retomou esses Ensaios, talvez porque, embora algumas de suas ideias possam ter passado por fluxos e refluxos, num processo de amadurecimento, no que toca à lei de natureza sua convicção, aparentemente, não mudou, seja sobre a sua existência e obrigatoriedade, seja em relação a como podemos conhecê-la.
} 
existente relação sociável" no estado de natureza, mostram a base do poder político, como se pretende desenvolver a seguir.

\subsection{Da Condição Natural do Homem}

A par da compreensão da lei de natureza, outro argumento-chave da análise do pensamento político lockiano é o entendimento do que ele denomina de estado de natureza. A partir daí é que se tem por possível captar a noção e a origem do poder político, bem como as condições legítimas de uma possível submissão (LOCKE, 2005, II, 4).

Locke, no seu escrito político Ensaio Sobre a Verdadeira Origem, Extensão e Fins do Governo Civil, define o poder político como sendo

[...] o direito de editar leis com pena de morte e, consequentemente, todas as penas menores, com vistas a regular e a preservar a propriedade, e de empregar a força do Estado na execução de tais leis e na defesa da sociedade política contra os danos externos, observando tão-somente o bem público (LOCKE, 2005, II, 3).

$\mathrm{Na}$ reflexão acerca da origem do poder político e da relação de poder, há que se entrelaçar as seguintes proposições: a) o poder político é o poder de editar e executar leis e promover a defesa individual e coletiva (LOCKE, 2005, II, 3), e b) somente se pode entender o poder político, na "medida em que se considere o estado em que todos os homens naturalmente estão" (LOCKE, 2005, II, 4).

A compreensão da origem da sociedade civil e da relação de poder - poder político -, necessariamente, requer a análise do estado natural do homem. Impõe pensar o ser humano no seu estado natural, despido dos artifícios sociais inerentes às organizações políticas, pois tais 
reflexões é que mostrarão as razões da instituição do corpo político, do poder comum e da autoridade deste sobre os homens ${ }^{35}$.

Na verdade, a reflexão sobre a condição natural do homem requer voltar o olhar para a própria natureza do homem e para a análise de um bem humano, segundo Locke, extremamente essencial: a liberdade. A noção de liberdade natural em Locke é o que permite a delimitação da concepção de governo, precisamente, no que toca ao limite do poder civil e à autoridade deste.

Com efeito, Locke afirma que o ser humano "nasce livre e racional" e, por assim ser, todos são iguais e independentes, logo, a instituição do governo e a sujeição política passam a ter configurações próprias, com o possível entendimento de que a soberania espalha-se pela multidão de indivíduos livres, iguais e independentes, ensejando peculiaridades na submissão a um poder único.

Assim, na sua linha de raciocínio, Locke procura justificar a origem e a necessidade da instituição de um governo - poder comum -, iniciando a sua tese argumentativa através da descrição dos seres humanos antes da formação da sociedade civil, ou seja, tal como viviam e se comportavam anteriormente à necessária intervenção e criação da sociedade política e da lei civil $^{36}$. Descreve, então, a condição natural do homem como um estado de perfeita liberdade de agir e de igualdade, estabelecendo um modelo dicotômico: o estado pré-político, o estado de natureza, sob a égide da lei de natureza, e o estado civil, político, sob a égide do direito positivo e de uma autoridade política.

Locke, no Segundo Tratado Sobre o Governo Civil, expõe que o estado natural do homem é um estado de perfeita liberdade, seja para agir ou dispor de sua pessoa ou de sua propriedade, nos limites estabelecidos pela lei de natureza. Segundo explica, é um estado no qual o homem é livre para agir e regular suas ações e disposições de sua posse, da maneira

\footnotetext{
${ }^{35}$ As discussões acerca do estado de natureza já se encontravam em pensadores anteriores a Locke, como Hugo Grotius e Samuel Pufendorf. Na verdade, o século XVII, bem como o anterior, procura negar o poder de tradição teológico medieval, apresentando o "estado de natureza" como um recurso metodológico para uma via explicativa para a origem do poder. As noções de indivíduo, lei natural e estado de natureza formaram o elo de argumentação da discussão política dominante do citado século e se consolidaram na formação do pensamento político moderno.

${ }^{36}$ Locke, na trilha de seus antecessores, como Thomas Hobbes, apartando-se da teoria aristotélica do homem como animal político e de que a família precederia a sociedade política, procura estabelecer um modelo de homem livre dos artifícios da organização social, tal qual a conhecemos. Traz, assim, um modelo de vida e de organização natural dos homens, com o intuito de bem entender as origens do poder político. Imagina os homens vivendo sem hierarquia, sem qualquer tipo de autoridade, antes de sua organização política.
} 
que mais the aprouver e que julgar acertado, nos limites, é claro, da lei de natureza, independentemente de licença ou da vontade dos outros homens (LOCKE, 2005, II, 4$)^{37}$.

Se a compreensão do poder político e de sua origem implica analisar o estado natural do homem, deve-se destacar as principais características deste estado (LOCKE, 2005, II, 4):

- total liberdade para agir e regular suas posses e pessoas segundo sua conveniência, independentemente de permissão ou vontade de outrem, dentro dos limites da lei de natureza;

- igualdade, pois todos são criaturas da mesma espécie e aquinhoados com as mesmas vantagens da natureza e com uso das mesmas faculdades, não havendo subordinação ou sujeição, pois o poder e jurisdição são recíprocos, ninguém tem mais poder do que o outro;

- paz, boa vontade, amizade, cooperação mútua e preservação - a convivência se dá segundo a razão (LOCKE, 2005, II, 19);

- ausência de um poder, de um governo comum e de uma lei civil - direito "objetivo"-, a regular a conduta humana.

O eixo da tese lockiana a ser ressaltado é o de que os homens, "na condição em que se encontram", são livres e iguais, não se encontram submetidos a nenhum poder na Terra, estão longe de se submeter ao poder de outro homem, e são governados tão-somente pela razão e pela lei de natureza.

Não se pode deixar de observar a extrema dificuldade de imaginar o homem no seu estado natural, sem qualquer artifício da organização sociopolítica. A reflexão lockiana: "No começo tudo era América e ainda mais do que ela é agora" (LOCKE, 2005, II, 49) pode ser que, de fato, não nos remeta ao homem no seu "primórdio". Mas a sua tentativa em nos aproximar do que denomina de "estado natural" - ausência de um governo comum e de uma lei positiva - através dos exemplos da "América" nos remete a comunidades "sem os formais aparatos civis" e em aparente bem-estar. Possivelmente, esse era o seu desiderato: explicar o poder político a partir do homem vivendo sob a égide da lei de natureza, em comunidade com certa organização e relações sociais inerentes.

\footnotetext{
${ }^{37}$ A liberdade para Locke é um bem supremo - direito natural -, e no estado de natureza os homens são livres de qualquer poder na Terra, isto é, não estão submetidos ao poder de outro homem. Esta é a principal característica do estado de natureza lockiano.
} 
Atento às possíveis objeções a respeito "de onde estão, ou se em algum tempo estiveram os homens em tal estado de natureza", Locke responde que, por ora, basta como resposta a observação de que "todos os príncipes e chefes de governos independentes no mundo inteiro encontram-se num estado de natureza, claro está que o mundo nunca esteve nem jamais estará sem um certo número de homens nesse estado" (LOCKE, 2005, II, 14). O autor faz alusão, aqui, a todos os governantes de comunidades políticas independentes, estejam ou não "em ligações com outros", pois que "todas as sociedades políticas se encontram em estado de natureza umas com relação a outras" (LOCKE, 2005, II, 183), face à ausência de um poder comum, de uma autoridade comum superior a elas.

Consciente da falta de documentação ou outro elemento forte a "comprovar" sua teoria, Locke salienta que não é de se estranhar que a história pouco nos conte sobre homens que viveram juntos no estado de natureza. O governo em toda parte antecede aos registros históricos, todavia, a escrita raramente se introduz no seio de um povo "antes que um longo período de sociedade civil tenha provido, por outras artes mais necessárias, segurança, conforto e abundância” (LOCKE, 2005, II, 101). Daí conclui que, se pudermos aceitar os escritos de "Jose Acosta, ele nos diz que em muitas partes da América não havia absolutamente nenhum governo [...] por muito tempo não conheceram nem reis nem sociedades políticas [...]" (LOCKE, 2005, II, 102). ${ }^{38}$

Confiante na sua explicação, no decorrer de seu Segundo Tratado, Locke procura descrever o estado de natureza - a condição natural do homem antes da "criação" da comunidade política - atribuindo-lhe caráter histórico. Retira o caráter de mera hipótese, trazendo exemplos da história para dar subsídios ao "caráter histórico" de seu pensamento político.

Nas passagens a seguir, Locke evidencia a sua definição de estado natural - condição natural do homem -, inclusive ressaltando o aspecto moral existente neste estado:

[...] os homens podem celebrar entre si outros pactos e promessas e, mesmo assim, continuar no estado de natureza. As promessas e acordos de troca etc.

\footnotetext{
${ }^{38}$ De qualquer forma, Locke não se perturba com as objeções de que não se teria exemplo na história de um agrupamento de homens independentes e iguais entre si e que se tenham reunido, estabelecendo um governo, argumentando que, se fosse possível admitir que os homens jamais tenham vivido no estado de natureza porque não se ouviu falar muito deles "em semelhante estado, podemos igualmente supor que os soldados de Salmanasser ou de Xerxes nunca foram crianças, porque muito pouco ouvimos falar deles antes que fossem homens e estivessem incorporados em exército" (LOCKE, 2005, II, 101). Ora, para fugir da "mera especulação", segundo Alexis Tadié, Locke explica que se encontram exemplos de estado de natureza que oferecem testemunho de sua "existência real (2T14-15; 2T103); e em certos relatos de viajantes ele encontra indícios da existência de homens que vivem ainda no estado de natureza" (TADIÉ, 2005, p. 52).
} 
entre dois homens numa ilha deserta mencionados por Garcilaso de la Vega em sua História do Peru, ou entre um suíço e um índio nas florestas da América, comprometem a ambos, embora em referência um ao outro eles estejam num perfeito estado de natureza. Pois a verdade e a observância da palavra dada cabem aos homens como homem, e não como membro da sociedade" (LOCKE, 2005, II, 14).

Pois sempre que houver dois homens que não tenham uma regra estabelecida e um juiz comum a quem apelar na Terra, para determinar as controvérsias de direito entre eles, esses homens se encontrão no estado de natureza e sob todos os inconvenientes destes [...] (LOCKE, 2005, II, 91).

$\mathrm{Na}$ esteira de Rolf Kuntz, na análise das passagens citadas, pode-se afirmar que Locke constrói o seu cenário natural partindo da seguinte negação: elimina-se a autoridade política, a legislação positiva, o controle da força e o tribunal comum. Além disso, é importante considerar que, "ao contrário de Hobbes, porém, Locke não concebe o homem natural como guiado apenas por apetites, temores e cálculos” (KUNTZ, 2004, p. 95-96). O perfil do homem natural lockiano, quando guiado pela razão, é voltado para a amizade e a paz, logo, para a vida em perfeita harmonia.

É certo que o seu empenho não o poupou de críticas severas, a ponto de se afirmar que os seus exemplos não significariam mais que uma forma um tanto quanto "forçada" de adequar "a história à sua concepção de história". Dessa forma, tanto o estado de natureza quanto o estado de guerra, que "antecedem o estabelecimento do Estado, são históricos, em Locke, porque ele percebe na história um momento cujo conteúdo se identifica com sua concepção destes estados" (REIS, 1988, p. 35).

Todavia, sobre a dificuldade do tema, a ponderação de Rolf Kuntz finaliza qualquer contenda ou especulação sobre o assunto:

Não é preciso supor o estado de natureza como historicamente determinado e reconstituir, para cada sociedade política, um momento de criação. O natural está diante de nós o tempo todo, nas manifestações comuns da psicologia, nas operações da razão (embora a própria razão se desenvolva) e nas situações em que falta a proteção oferecida por um poder comum (KUNTZ, 2004, p. 95).

Hipotético ou histórico, a questão é evidenciar as características do estado de natureza e da condição natural do homem sob o entendimento lockiano, pois desta análise é que decorre a linha mestra da futura relação entre governo e governados.

A primeira interpretação que surge é a de que homens livres possuem o direito de agir "livremente", uma vez que não estão sujeitos à norma vinculante positiva, podendo regular 
suas ações da maneira que lhes parecer mais conveniente, sem carecerem de permissão ou vontade alheia. No entanto, Locke adverte que, embora os homens no estado de natureza não estejam submetidos a "qualquer poder na terra", ou seja, não haja subordinação entre os mesmos, pois são livres e iguais, esta liberdade não implica licenciosidade ${ }^{39}$. O seu argumento para impedir a permissividade ou um "viver dissoluto" é o de que, "embora o homem nesse estado tenha uma liberdade incontrolável para dispor de sua pessoa ou posses, não tem liberdade para destruir-se ou a qualquer criatura em sua posse, a menos que um uso mais nobre que a mera conservação desta o exija" (LOCKE, 2005, II, 6).

Locke, ao frisar claramente que a liberdade não implica licenciosidade, insere o seu inarredável elemento-chave: "o estado de natureza é governado pela lei de natureza, que equivale à razão" (ou reta razão). Esta lei obrigatória "ensina a todos que a consultem que por serem todos os homens iguais e independentes, ninguém deve prejudicar a outrem na vida, saúde, liberdade e posse" (LOCKE, 2005, II, 6). Essa conclusão é consequência do fato de que os homens, por serem criaturas de Deus, devem durar o quanto Ele quiser, logo, ninguém está autorizado a destruir a si ou a qualquer criatura de Sua posse ${ }^{40}$.

A liberdade natural é atributo de suma importância na compreensão do pensamento político lockiano, uma vez que nos fornece a base e a extensão das relações de poder. O ser humano, como criatura de Deus, ser racional, na medida em que é livre, é senhor de si. Este é o elemento fundamental que caracteriza os homens nas suas relações, pois principia um processo peculiar de individuação:

o que caracteriza a princípio um homem enquanto indivíduo e o torna distinto e independente de todos os outros é sua liberdade natural. Cada homem está, por natureza, num estado de perfeita liberdade, dispõe de si próprio e encontra-se independente da vontade de qualquer outro indivíduo. Assim individualizado por sua liberdade natural, cada um se afirma como igual a cada um dos outros e dotado pela natureza das mesmas vantagens e das mesmas faculdades, em particular da mesma razão (POLIN, 2003, p. 160).

\footnotetext{
${ }^{39}$ Bem supremo, a liberdade é reconhecida por Locke como uma qualidade humana que confere poder para realizar ou deixar de realizar uma ação, conforme determinação de uma lei ou do pensamento (entendido este como lógico-racional). Assim, as ações originadas da mera vontade ou impulsividade não são ações livres para Locke, que confere especial atenção para o controle da vontade-desejo-paixão, pregando a seletividade. A razão e a deliberação são os guias das ações a serem executadas, tornando o homem livre.

${ }^{40}$ Locke faz uma concessão: ninguém tem a liberdade de destruir-se ou a qualquer outra criatura, "a menos que um uso mais nobre que a mera conservação desta o exija", ou seja, em caso de ser preciso castigar um ofensor que atente contra a preservação da vida, da liberdade, da saúde, ou contra os bens dos membros da comunidade natural (LOCKE, 2005, II, 6). Vale dizer, somente para a própria preservação ou preservação da humanidade é que se pode "ferir ou matar" alguém.
} 
A liberdade convive com a igualdade de todos. $\mathrm{Na}$ verdade, é a igualdade que define a liberdade, pois todos possuem a mesma faculdade, compartilhando de natureza comum. Logo, não há subordinação e um não pode subjugar ou destruir a outrem. A igualdade entre os homens, a ausência de subordinação, em termos lockiano, tem fundamento divino: Deus criou os homens iguais, não autorizando qualquer hipótese de eventual desigualdade, ou seja, não "rotulou" este ou aquele como superior aos demais:

[...] sendo absolutamente evidente que criaturas da mesma espécie e posição [...] devam ser também iguais umas às outras, sem subordinação ou sujeição, a menos que o Senhor e amo de todas elas, mediante qualquer declaração manifesta de Sua Vontade, colocasse uma acima de outra e lhe conferisse, por evidente e clara indicação, um direito indubitável ao domínio e à soberania (LOCKE, 2005, II, 4).

Consequência lógica da igualdade é que todo homem tem a obrigação de preservar-se e a toda a humanidade, exceto se houver risco para a sua própria preservação (LOCKE, 2005, II, 6). E esta igualdade, que acarreta a todos os mesmos deveres e eventuais direitos, impõe a exigência do respeito mútuo (LOCKE, 2005, II, 5) - obrigação - para o bem viver em comunidade.

A ausência de um poder comum, para Locke, não cria qualquer obstáculo para a vida em comunidade, pois os homens não estariam desobrigados da obediência à lei de natureza e de zelar pelo cumprimento desta. A lei de natureza, uma vez observada, traz a paz e a preservação da humanidade. E, para garantir a sua observação e impedir sua violação, ou seja, para impedir que os homens invadam os direitos alheios ou mutuamente se molestem, Locke desenvolve a teoria de que a execução da lei de natureza cabe a todos os homens.

Todos possuem o direito de castigar os transgressores da lei. Primeiro, porque uma lei seria inócua se não impusesse castigo à sua inobservância e, segundo, pois por natureza não há superioridade ou jurisdição de um sobre o outro, "o que qualquer um pode fazer na prossecução dessa lei, todos necessariamente devem ter o direito de também o fazer" (LOCKE, 2005, II, 7).

O direito de executar a lei de natureza é inerente ao direito de preservação. Todavia, este poder não é absoluto e arbitrário para "lidar com o criminoso". Não se deve usá-lo segundo a cólera, paixões ou extravagância da própria vontade, mas deve ser usado para a reparação e restrição, ou seja, tão-somente para revidar, de forma proporcional, a 
transgressão, segundo os ditames da razão, provocando arrependimento, e pelo exemplo impedir que outros cometam semelhante transgressão (LOCKE, 2005, II, 8).

Para Locke, aquele que transgride a lei de natureza, v.g., matar a outrem, torna-se perigoso para toda a humanidade, "quebrando o pacto de garanti-la contra danos e agressões". Subentende-se, então, que o ofensor não obedece à lei da razão, cometendo um crime contra toda a espécie, contra a paz e a segurança estabelecida pela lei de natureza, e por isso pode ser “destruído" por qualquer um de seus semelhantes (LOCKE, 2005, II, 8).

Observa-se que, de um lado, Locke descreve o ser humano como artefato de Deus, criado para viver de forma a não prejudicar a outrem e a cumprir os desígnios do Criador, devendo preservar-se e à humanidade, na busca da felicidade. De outro, traz uma situação que destoa da harmonia que deveria reinar no estado de natureza, falando em "transgressão" e “destruição de um semelhante" (LOCKE, 2005, II, 7 e 8).

Dúvidas saltariam sobre a condição natural humana - real natureza do homem - se Locke não se adiantasse a explicar que o estado de natureza é regulado pela lei de natureza. Logo, a observância da lei de natureza, norma reguladora de condutas, proporciona a paz e a harmonia entre os homens, independentemente de uma autoridade política. Ademais, é bom lembrar que, no estado de natureza, o único momento em que um homem livre obtém poder sobre outro homem livre - poder de fazer mal ao outro - é quando ocorre a transgressão da lei de natureza. Essa concessão decorre do direito de se preservar e de preservar a humanidade.

A lei que deve governar os homens é a lei da razão, sendo que o homem não estaria sujeito a caprichos ou à arbitrariedade alheia, mas somente à lei da razão. A liberdade natural consiste em não estar sujeito ao poder despótico de outrem, bem como em ter o controle da própria vontade. O homem livre lockiano é aquele que controla a impulsividade e as possíveis paixões, que possam "tentar dominar" o ser humano, tirando-lhe a sua condição de "ser racional" - condição esta dada por Deus, que criou todos os homens como seres livres e racionais.

O homem na sua condição natural é livre. No estado de natureza, o homem vive conforme sua livre vontade, mas governado pela lei de natureza, conhecida pela razão, o que mostra que a condição natural do homem é a de um ser "racional", que se destina a agir de acordo com uma lei: a lei de natureza. Viver sob a égide dessa lei, conforme assinalado, implica pautar-se pela "reta razão", viver em perfeita harmonia, envolto pela paz social, 
preocupado com a conservação de toda humanidade, vivenciando o respeito mútuo ${ }^{41}$. Locke confia em um ser humano racional que pode impor a si mesmo limites, normas reguladoras de condutas, independentemente de uma autoridade política e de uma legislação positiva.

No entanto, emerge a questão da possibilidade de eventual quebra dessa harmonia social, do desequilíbrio da paz social, caso se deixe de observar a lei de natureza. Segundo Locke, isso é possível na medida em que o ser humano abandone a razão, deixando-se levar pelas paixões ou pela “ilimitada extravagância da vontade”, apartando-se da racionalidade.

Como vimos, transgredir a lei de natureza significa viver segundo outra regra, que não a da razão e da equidade comum, "que é a medida fixada por Deus às ações humanas para mútua segurança destes; e, assim, torna-se ele perigoso para a humanidade, afrouxando ou rompendo os laços que servem para guardá-la da injúria e da violência” (LOCKE, 2005, II, 8).

A ofensa ou mal causado à vida, liberdade ou outro bem (propriedade - algo que lhe seja lícito chamar de "seu" ou "meu") de uma determinada pessoa, consiste em uma agressão contra toda espécie e "contra a paz e segurança proporcionadas pela lei da natureza" (LOCKE, 2005, II, 8). Coloca-se em risco o equilíbrio e a harmonia da condição natural do homem, macula-se o estado de perfeita liberdade e igualdade. Isso traz instabilidade ao estado de natureza - estado de paz - ocasionando um estado de guerra, ou seja, de discórdia, de desarmonia.

A igualdade existente no estado de natureza, como assinalado, atribui a todos os homens o direito de magistrado - de juiz -, ou seja, o direito de julgar e punir. Todos podem, dessa forma, castigar quem de alguma maneira venha a descumprir a lei de natureza. Nas palavras de Locke:

e para que todos os homens sejam impedidos de invadir direitos alheios e de prejudicar uns aos outros, e para que seja observada a lei de natureza, que quer a paz e a conservação de toda humanidade, a responsabilidade pela execução da lei de natureza é, nesse estado, depositada nas mãos de cada homem, pelo que cada um tem o direito de punir os transgressores da dita lei em tal grau que impeça sua violação. Pois a lei de natureza seria vã, como todas as demais leis que dizem respeito ao homem neste mundo, se não houvesse alguém que tivesse, no estado de natureza, um poder para executar

\footnotetext{
${ }^{41} \mathrm{O}$ estado de natureza é regulado pela lei de natureza, que a todos obriga, pautando a ação humana. Vale lembrar que esta lei, que é conhecida pela razão, mostra que, em função da igualdade e liberdade inerentes a todos, ninguém deve prejudicar outrem, no que toca à própria liberdade, vida, saúde ou posses. Direitos e obrigações se justapõem na combinação entre a lei e a liberdade. $O$ homem livre é sempre definido nos parâmetros de leis e, no estado de natureza, é regulado pela lei de natureza - própria razão - que "quer a paz e a conservação de toda a humanidade" (LOCKE, 2005, II, 7).
} 
essa lei e, com isso, preservar os inocentes e conter os transgressores (LOCKE, 2005, II, 7) $)^{42}$.

Nada mais coerente do que a punição aos que transgridem a lei de natureza, uma vez que se colocou em risco toda a humanidade. $\mathrm{O}$ crime não se dá somente contra aquele que foi diretamente ofendido e sim contra todos, contra a humanidade.

A transgressão quebra o equilíbrio que deveria vigorar entre os seres humanos, razão pela qual se atribui a todos o poder de punir. A consequência natural da inobservância da lei é a punição, a aplicação de um castigo ao transgressor, àquele que deixou de seguir a razão, causando certa desarmonia entre os homens livres e iguais, causando dificuldade para se viver no estado de natureza.

Locke denomina o poder recíproco de execução da lei de natureza (julgar e punir) de "estranha doutrina". Acrescenta, ainda, que o fato de que todos possam punir "as infrações, ainda que menores que as que acarretem a morte", pode ocasionar certo espanto ou dificuldade de entendimento deste poder. Estas objeções consistiriam em argumentos como o de que não seria razoável deixar o próprio homem ser juiz de sua própria desavença, pois ele poderia ser parcial, não só em relação a si próprio, como também a seus próximos. Isso porque as paixões humanas, sentimentos de vinganças, ou mesmo certa inclinação para o mal, poderiam acarretar "excesso na punição", deflagrando mais desordem e confusão ${ }^{43}$.

Aqui, ao expor as possíveis objeções, Locke já deixa entrever a sensível necessidade de um poder comum e imparcial para punir eventuais transgressores, enfatizando que, por essa razão, "Deus teria estabelecido o governo para restringir a parcialidade e a violência dos homens" (LOCKE, 2005, II, 13). A este ponto, retornaremos mais adiante. Analisemos agora o alcance do pensamento lockiano acerca dos inconvenientes do estado de natureza (LOCKE, 2005, II, 91) e do denominado estado de guerra, ponto de relevante articulação na origem da sociedade civil.

\footnotetext{
${ }^{42}$ Todos têm o direito de punir o transgressor e de ser o executor da lei de natureza, seja pelo grau da ofensa ou pelo direito que todos os homens possuem de preservar-se e de preservar a humanidade em geral. O direito de punir o transgressor permite fazer "recair sobre qualquer um que tenha transgredido essa lei um mal tal qual que o faça arrepender-se de o ter praticado e, dessa forma, impedi-lo - e por seu exemplo a outros - de praticar o mesmo mal" (LOCKE, 2005, II, 8).

${ }^{43}$ A "estranhíssima doutrina" descrita por Locke, pela qual cada indivíduo, em seu estado pré-político, pode ser o "executor da lei de natureza", com o direito de empunhar o gládio da justiça em sua própria causa, servirá de pano de fundo ao seu "direito de resistência", no estado político. Neste sentido James Tully, para quem, toda a descrição do estado de natureza lockiano volta-se a construir um cenário para introduzir a revolução como algo natural e legítimo a refrear os governantes que abusem do poder. Na sua leitura, o tema dos Dois Tratados é estabelecer justificativas para o direito de resistência (TULLY, 1993, p. 41).
} 


\subsubsection{Do Possível Estado de Guerra}

O estado de natureza é regulado pela lei de natureza, descoberta pela razão, que determina a todos "que um não deve prejudicar a outrem". Face a esta norma, o princípio da confiança (de que todos agirão desta forma) torna-se a "lei" norteadora do agir humano. Todavia, não obstante tal premissa, Locke se viu forçado a refletir sobre certas dificuldades de se viver sob a égide dessa lei, uma vez que, por determinadas razões, nem todos permeiam sua conduta pela regra acima citada.

Cônscio dos possíveis riscos das "paixões" humanas, Locke se depara, então, com a possibilidade de eventual prática de ato contrário aos ditames da razão. Situação constrangedora que traz para o estado de natureza um estado de guerra - estado de desarmonia e agravos mútuos, da força e da violência.

Locke refere-se ao estado de guerra como sendo um

[...] estado de inimizade e destruição; portanto, aquele que declara, por palavra ou ação, um desígnio firme e sereno, e não apaixonado ou intempestivo, contra a vida de outrem, coloca-se em estado de guerra com aquele contra quem declarou tal intenção e, assim, expõe sua própria vida ao poder dos outros, para ser tirada por aquele ou por qualquer um que a ele se junte em sua defesa ou adira a seu embate (LOCKE, 2005, II, 16).

$\mathrm{Na}$ visão lockiana, a descrição desse estado de desarmonia equivale a uma expressa e declarada intenção "ponderada e fria" contra a vida de outrem, por meio de palavra ou ação. Não se trata de ação - intenção - movida por paixão ou precipitação, e "sim movida pela força e violência" de forma "calculada".

Aquele que se coloca nesta situação - neste agir - coloca-se em desacordo com a lei de natureza (deixou de ouvir a razão), podendo ficar sob o poder de outrem e ser castigado, tido e tratado como fera, "criaturas perigosas e nocivas que seguramente nos destruirão se cairmos em seu poder" (LOCKE, 2005, II, 18), pois se colocou em estado de guerra contra a humanidade. Locke tem o cuidado de lembrar que, pela lei de natureza deve-se preservar o homem, todavia deve-se dar preferência à segurança do inocente, destruindo quem promove a "guerra" ou manifesta inimizade à existência humana.

A preocupação com a liberdade natural é evidente. Segundo Locke, "aquele que tenta colocar a outrem sob seu poder absoluto, põe-se consequentemente em estado de guerra com ele". Esta atitude pode ser entendida como uma clara intenção de prejudicar a vida do 
próximo, pois se pode concluir que quem a outrem subjuga sem o seu consentimento poderá fazer uso deste como lhe aprouver, enquanto o mantiver cativo, podendo inclusive matá-lo "se tal for seu capricho" (LOCKE, 2005, II, 17).

Locke parte da premissa de que ninguém deseja manter outrem sob seu poder a não ser para forçá-lo a fazer o que é contrário à liberdade, ou seja, torná-lo escravo. Logo, quem tenta escravizar a outrem se põe em estado de guerra e a razão, nesse caso, nos diz para tê-lo como inimigo da própria preservação, da preservação da humanidade.

A seguinte passagem do Segundo Tratado resume bem a preocupação lockiana com a liberdade e denota a interdependência desta com a igualdade de todos:

Aquele que, no estado de natureza, subtrai a liberdade que cabe a qualquer um em tal estado deve necessariamente ser visto como imbuído da intenção de subtrair todo o resto, sendo tal liberdade o fundamento de todo o mais, assim como deve presumir que aquele que, no estado de sociedade, subtrai a liberdade que cabe aos membros dessa sociedade ou Estado tem a intenção de subtrair a estes todas as demais coisas, devendo ser considerado, portanto em estado de guerra (LOCKE, 2005, II, 17).

A presente passagem evidencia que o "estado de guerra" não é característica inerente ao estado de natureza, podendo ocorrer também no estado civil, pois equivale a uma postura de desrespeito à condição de igualdade e de liberdade do homem. A liberdade só é possível na medida em que os homens são iguais, o que implica afirmar que, por natureza, "um não pode 'mandar' ou subjugar o outro", ou seja, a liberdade somente se afirma ou tem sentido com o respeito da perfeita igualdade.

O uso da força e da violência quebra a igualdade, retira a liberdade - bem precioso, seja no estado natural ou civil. Advém daí a legitimidade da "estranhíssima doutrina", o direito de punir (de autodefesa), "pois é razoável e justo que eu tenha o direito de destruir aquele que me ameaça de destruição [...]" (LOCKE, 2005, II, 16) ${ }^{44}$.

Na medida em que Locke menciona que "aquele que deixou de fazer uso da razão" ou "aquele que age pela força ou pela violência" instala "o estado de guerra", quer nos levar a crer na possível simultaneidade destes estados. A boa convivência é a regra, na condição natural do homem, guiado pela razão. O estado de guerra é a exceção, surge somente por um

\footnotetext{
${ }^{44}$ Observa-se que Locke, em defesa da liberdade, torna legítima uma possível responsabilização objetiva, pois afirma que aquele que no estado de natureza, forçosamente, tira a liberdade que cabe a todos pode ser considerado suspeito de querer tirar tudo o mais, porque a liberdade é o fundamento de todo o resto, logo, é lícito considerá-lo em estado de guerra (LOCKE, 2005, II, 18).
} 
desvio da natureza, na medida em que o homem deixa de ouvir a razão, renunciando à sua condição de homem livre e racional.

As observações lockianas sobre o "estado de guerra" suscitam a indagação sobre ser pacífico ou não o seu estado de natureza. Não se descuida que a presente questão pode ser considerada vital na compreensão de seu pensamento, pois Locke quer nos mostrar que os homens são capazes de agir, de forma racional, sem a necessidade de leis positivas e autoridade comum. No entanto, não se nega que, ao descrever o seu estado de guerra "mútuos agravos, injúrias e males que assediam os homens" (LOCKE, 2005, II, 91), Locke suscita dúvidas sobre a harmonia do estado de natureza. Mas Locke busca desfazer essa questão, sinalizando clara diferença entre o estado de guerra e o estado de natureza, pois estes estão tão distantes "um do outro quanto um estado de paz e boa vontade, assistência mútua e preservação está de um estado de inimizade, malignidade, violência e destruição mútua" (LOCKE, 2005, II, 19). Segundo explica, enquanto os homens vivem em conformidade com a razão, sem um superior comum com autoridade para julgá-los, ou melhor, sem a necessidade de um superior para julgá-los, estão em estado de natureza. Todavia, a manifestação da força, "ou um propósito declarado de força sobre a pessoa de outrem, quando não haja um superior comum sobre a Terra ao qual apelar em busca de assistência, constitui o estado de guerra" (LOCKE, 2005, II, 19).

Em suma, o estado de natureza difere do estado de guerra, na medida em que o primeiro é um estado de paz, boa vontade, cooperação mútua e preservação, enquanto o segundo é um estado de inimizade, malícia, violência e destruição recíproca. Isso estabelece o seguinte quadro:

- Estado de natureza: convivência segundo a razão, sem uma autoridade superior comum no mundo que possa julgar entre eles.

- Estado de guerra: uso da força ou intenção declarada contra a pessoa de outrem, quando não exista instância superior, na Terra, a quem apelar.

- Direito de guerra contra o agressor: direito-liberdade de punir-matar o agressor (que atentou contra a vida ou bens de alguém) - autodefesa - por não ter a possibilidade de apelar a um juiz comum.

- Direito de reparação: direito de exigir a reparação do mal-dano sofrido, independentemente do direito de castigar. 
Coerente com sua doutrina ética, Locke não admite uma sequência ou uma transição entre o estado de natureza, o estado de guerra e o estado civil. Na verdade, percebe-os ocorrendo de forma simultânea, sendo que o estado de natureza (de paz) vem a ser a regra, e o estado de guerra (belicoso) seria a exceção.

Para Locke, a diferenciação é clara: a ausência de um juiz comum, com autoridade sobre os homens livres e iguais, coloca a todos em estado de natureza, enquanto o uso da força sem direito leva ao estado de guerra, independentemente da existência de um juiz comum (LOCKE, 2005, II, 19) ${ }^{45}$. Locke evidencia a necessidade de regras e de consentimento dos homens para o uso do poder sobre outrem, sob pena de ilegitimidade.

Ora, a "quebra do equilíbrio" do estado de natureza acarreta o direito de punir atribuído a todos. Se qualquer um pode punir a outrem, relativamente a qualquer mal que tenha cometido, isso significa que "todos podem fazer", pois, nesse estado de perfeita igualdade, no qual "naturalmente não existe superioridade ou jurisdição de um sobre o outro", o que um pode fazer na execução da lei "todos devem necessariamente ter o direito de fazer" (LOCKE, 2005, II, 7).

A punição - o direito de fazer cumprir e executar a lei de natureza - é uma questão delicada para Locke, pois um homem obtém poder sobre o outro. Não se trata de um poder absoluto ou arbitrário, é certo, sendo justificável pela regra da preservação da humanidade. Neste poder sobre o outro, Locke admite dois direitos distintos a consumar a punição e aplicar a lei de natureza:

1) o direito de punir o crime para restringir e evitar que o mesmo delito volte a ocorrer, sendo que este direito seria natural a todos os homens - poder comum a todos;

2) direito de obter a reparação pelo eventual dano causado por quem "promoveu" o estado de guerra, inerente tão-somente ao prejudicado - vítima.

O direito comum de punir pode ser relevado, mas não se pode relevar a reparação devida a qualquer homem particular pelo dano sofrido. O prejudicado com a conduta transgressora, ou seja, aquele que sofreu o dano tem o direito de exigir em seu próprio nome a reparação, e somente ele pode relevar ou deixar de exigir tal reparação. Como decorrência do

\footnotetext{
${ }^{45}$ Locke, aqui, não só anuncia a necessidade de uma legislação positiva e um poder político único, como também já mostra o gérmen da sua teoria de resistência no estado civil. Estes apontamentos sobre o estado de guerra e da "estranhíssima doutrina" serão determinantes na conformação da comunidade natural em uma comunidade civil.
} 
direito de autoconservação, a pessoa prejudicada tem o poder de apropriar-se dos bens ou serviços do transgressor. A lógica é que "todo homem tem o poder de punir para evitar" que "delitos" sejam cometidos novamente, "em virtude do direito que tem de conservar a toda a humanidade e de fazer tudo o que for razoável para atingir tal fim” (LOCKE, 2005, II, 11).

O direito de execução da lei de natureza, poder de punir, descrito por Locke, pode ensejar algumas dúvidas. De um lado, apresenta certa preocupação com a "proporcionalidade da pena a ser infligida" e, de outro, parece nos mostrar a possibilidade de uma "responsabilidade objetiva" e aplicação de penalidade desproporcional à infração cometida. É esta desproporcionalidade que coloca em xeque a aplicação da estranha doutrina, deixando entrever a necessidade de um magistrado - poder único -, gerando a idéia do governo civil.

Com efeito, Locke adverte inicialmente que esse poder não seria ilimitado, devendo ser concretizado com certa proporcionalidade no que toca à prevenção e à reparação. Assim, embora se esteja em um estado de perfeita liberdade e igualdade, no qual todos os "livres e iguais" podem castigar (poder/dever de executar a lei), e não haja, por natureza, superioridade ou jurisdição de um sobre o outro, o poder de punir não é arbitrário e nem absoluto.

No estado de natureza, com a transgressão à lei de natureza (ofender a outrem e à humanidade) surge a possibilidade de se obter um poder sobre outrem, para puni-lo e evitar novos gravames. Todavia, Locke adverte que:

não se trata, porém, de um poder absoluto ou arbitrário, para se usar com um criminoso, quando a ele se tem em mãos, segundo as paixões ou a ilimitada extravagância da própria vontade, mas apenas para retribuir, conforme dita a razão calma e a consciência, de modo proporcional à transgressão [...] (LOCKE, 2005, II, 8).

Locke demonstra, nesta passagem, clara preocupação com a imposição de castigo, devendo este ser adequado à reparação e à restrição necessárias ao caso. Aqui, é importante frisar que este é o único motivo pelo qual a lei de natureza autorizaria subjugar a outrem, causar-lhe um mal, pois o transgressor, por se afastar da razão (medida fixada por Deus aos homens para o convívio social), tornou-se perigoso à humanidade. Desse modo, pode-se restringir ou, quando necessário, destruir o que seja nocivo à preservação da humanidade, uma vez que o mal a ser imposto ao transgressor deve ser tal que o faça arrepender-se e impeça nova prática, bem como venha a desestimular a outrem.

Todavia, embora mencione certa proporcionalidade entre a conduta e o mal causado e o castigo infligido, como retribuição, Locke, ao mesmo tempo, apresenta um tom severo em 
relação à conduta dos transgressores da paz (aqueles que se colocam em estado de guerra, desvirtuando o estado de natureza), estando longe de se perquirir sobre medidas punitivas proporcionais ao dano sofrido. Assim, observamos passagens nas quais pondera que, aquele que no estado de natureza vem a subtrair a liberdade de outrem (o coloca sob o seu poder absoluto), deve ser encarado como imbuído da intenção de subtrair todo o resto, pois "a liberdade é o fundamento de todo o mais" para o homem ${ }^{46}$.

Transgredir a lei de natureza, como assinalado, significa agir segundo outra regra que não a da razão. Daí, aquele que atentar contra a vida de alguém (ou outro bem) estará afirmando que não quer mais viver de acordo com a razão, regra concedida por Deus para o bom convívio entre os homens, e deverá ser banido como um animal selvagem (LOCKE, 2005, II, 172).

A subjugação se revela como uma questão delicada para Locke, defensor da liberdade e da igualdade, como se pode deduzir da sua inquietude ao refletir sobre as possíveis consequências das relações entre os homens vivendo juntos sem serem guiados pela razão:

Mas a força, ou um propósito declarado de força sobre a pessoa de outrem, quando não haja superior comum sobre a terra ao qual apelar em busca de assistência, constitui o estado de guerra. E é a falta de tal apelo que dá ao homem o direito de guerra até contra um agressor [...]. Desse modo, um ladrão, ao qual não posso fazer mal sem apelar para a lei por me ter furtado tudo quanto tenho de valor, poderá ser morto por mim quando quiser roubar apenas meu cavalo ou meu sobretudo, pois a lei, criada que foi para a minha preservação, sempre que não puder interpor-se para garantir contra a força presente minha vida, que se for perdida não será passível de qualquer reparação, permite-me minha própria defesa e o direito de guerra, com a liberdade de matar o agressor, pois este não me concede tempo algum para apelar ao nosso juiz comum, ou à decisão da lei, para remediar um caso em que o mal pode ser irreparável (LOCKE, 2005, II, 19).

Face à lei da autopreservação, é justo destruir aquilo que ameaça (todos são, naturalmente, juízes e executores da lei), no entanto, os inconvenientes da "estranha doutrina" surgem: o prejudicado pode não ter "força" para exigir a reparação, bem como não se pode

\footnotetext{
${ }^{46}$ No presente raciocínio, é legítimo matar um ladrão que fez uso da força para subtrair o dinheiro "ou que mais lhe aprouver", sem que tenha causado qualquer ferimento ou atentado contra a vida da vítima, pois se o transgressor fez uso da força para subjugar alguém, quando não tinha direito, pode-se supor que "aquele que toma a liberdade" pode tomar todo o resto. Logo, pode ser tratado como alguém que se colocou em estado de guerra, sendo legítimo "matá-lo se disso for capaz - pois a tal perigo se expõe, justamente, todo aquele que introduz um estado de guerra e nele é agressor" (LOCKE, 2005, II, 18). Talvez, a preocupação de Locke com o uso da força e subjugações, com a privação da liberdade e de outros bens inerentes ao ser humano, o tenha levado a afirmar que o agressor, por se afastar da razão e instalar um clima de insegurança, assumiu o risco de ser morto. Locke, ao que parece, sempre adianta o seu direito de resistência, pois, seja no estado de natureza ou no estado civil, aquele que tenta subjugar outrem, colocá-lo sob o seu poder, sem o seu consentimento, coloca-se em estado de guerra, uma vez que estaria atentando contra a sua vida e a outras possessões.
} 
descuidar da possível "parcialidade" dos julgamentos e da possível desproporcionalidade das penas.

O poder executivo da lei de natureza, bem como eventuais subjugações de fato entre os homens, acarreta outra preocupação: uma vez sobrestado o equilíbrio que deveria existir entre os homens, coloca-se em risco a paz de toda a humanidade, instalando-se certa insegurança na comunidade natural. Coloca-se em xeque o eventual retorno ao estado de credibilidade entre os homens livres e iguais - retorno à paz e à segurança entre os homens livres e iguais ${ }^{47}$.

Conclusão lógica é que, enquanto todos forem juízes, a igualdade pode ser desrespeitada, e os conflitos podem se extinguir com ressentimentos, maculando o estado de natureza. Desta forma a razão vai instituir o poder político para evitar essa possível condição degenerada e recuperar a paz. Para Locke, enquanto todos forem juízes, não se tem como garantir a liberdade, igualdade e propriedade, ou seja, a paz necessária nas relações entre os homens.

Para complicar mais ainda o entendimento das relações na condição natural do homem, Locke, no Segundo Tratado, entre a digressão sobre o estado de natureza e o estado civil, discorre sobre a propriedade. Talvez isso signifique a consciência de que a introdução do "meu" e do "teu" entre os homens, na medida em que as relações vão se tornando complexas, poderia trazer problemas concretos ao convívio entre aqueles que deixam de se nortear pela "estrela e bússola" da razão.

Assim, antes de adentrar o estado civil e perquirir sobre o procedimento instituidor deste, há que se abrir um parêntese na "relação natural dos homens" para uma analise, ainda que superficial, da relação destes com as suas posses, com o que Locke denomina de propriedade dos homens: "isto é, sua vida, liberdade e bens" (LOCKE, 2005, II, 87). Até porque, a finalidade da sociedade política é a preservação do que Locke denomina genericamente de "propriedade" (LOCKE, 2005, II, 123).

\footnotetext{
${ }^{47}$ Locke demonstra certa oscilação quanto à "proporcionalidade do castigo" - revide proporcional -, questão de difícil solução no elo entre estado de natureza e estado de guerra. O autor salienta que, se o homem pode chegar a ter, no estado de natureza, poder sobre o outro, há de se concluir que esse poder não é absoluto ou arbitrário em relação ao criminoso. E, com essas preocupações, concede que talvez o "direito de punir" possa trazer tantos inconvenientes quanto o próprio estado de guerra. O exercício desse poder está voltado ao revide, "de acordo com os ditames da razão calma e da consciência". E, por assim ser, deve ser executado proporcionalmente à transgressão. O castigo, como visto, deve servir como forma de reparação e restrição, que são os dois únicos motivos que autorizam, de forma legítima, a um "homem fazer mal a outro" (LOCKE, 2005, II, 8).
} 


\subsubsection{Relações e Ilações Naturais de Propriedade}

Locke, após discorrer sobre o estado de natureza e seus possíveis inconvenientes, antes de iniciar sua exposição sobre a sociedade política propriamente dita, tece importantes considerações sobre a propriedade, referindo-se ao seu sentido restrito de posse material. Aqui, procura evidenciar a forma legítima de apropriação e as regras pertinentes à mesma. Esta sua escolha impõe certa atenção e cuidado nas possíveis conclusões. Sobre o tema, observa Peter Lasllet que, "de forma abrupta, Locke insere na discussão o conceito de propriedade" (LASLLET, 2003, p. 254).

Tal escolha advém dos seguintes motivos: 1) outros bens como a vida, liberdade e igualdade, foram amplamente abordados no estado de natureza e 2) há certa complexidade nas relações entre os homens no que toca aos bens materiais, e a evolução desta requer um capítulo à parte. Ademais, como visto, nem todos escutam a lei da razão, e a noção do que seja "meu" e/ou "teu", na busca da autopreservação, de fato pode gerar "conflitos" que impulsionaram os homens decididamente à sociedade política ${ }^{48}$.

As relações envolvendo a propriedade privada, não raro tida como a "grande vilã" no contexto das relações humanas, foram e são objeto de grandes discussões. Locke, consciente desta problemática e tentando ser coerente com sua formação cristã, procurou elaborar a sua teoria da apropriação de bens naturais num contexto, pode-se dizer, ético. Não se pode negar que o capítulo V: "Da propriedade", no Segundo Tratado, mostra um Locke preocupado com o homem, não só como sujeito de direitos, mas sobretudo sujeito a sérias e determinadas obrigações naturais.

Locke mostra-nos um estado de natureza próximo a uma convivência de um promissor estado de bem-estar. Aparentemente, os homens possuíam uma vida boa, com bons relacionamentos entre si e com tudo o mais existente no mundo - na natureza. No início "o

\footnotetext{
${ }^{48}$ Por essa razão, torna-se importante uma análise, ainda que superficial, de alguns argumentos lockianos sobre a origem e legitimidade da propriedade. Até porque, essa relação originou-se no estado de natureza e é através deste que se poderá estabelecer conclusões sobre o poder político (LOCKE, 2005, II, 4). Ademais, via de regra, costuma-se afirmar que "a doutrina da propriedade de Locke, que é quase literalmente a parte central de sua doutrina política, é seguramente a sua parte mais característica. Distingue de forma muito clara a sua doutrina política, não só de Hobbes, mas também das doutrinas tradicionais. Por ser uma parte da sua doutrina da lei natural, partilha das mesmas complexidades" (STRAUSS, 2009, p. 201).
} 
mundo inteiro era a América" (LOCKE, 2005, II, 49): uma vida em comum, com coisas em comum, pois Deus deu o mundo aos homens em comum (Ibid., I, 26), dando-lhes também a razão, a propiciar uma vida boa, seja no aspecto material ou espiritual. O homem, através do uso diligente e racional, poderá usufruir de tudo quanto existe na natureza, para o seu sustento e conveniência da vida (Ibid., II, 26 e 31).

Pode-se dizer que Locke, inicialmente, visualiza um "comunismo originário". Já no Primeiro Tratado Locke ressaltava a máxima divina, grande desígnio de Deus: "Crescei e multiplicai-vos", pretendendo que, originariamente, ninguém é senhor ou possuidor de nenhum "pedaço de terra" e que ninguém poderia subjugar a outrem, por questões sociais, financeiras ou econômicas. Tudo pertence a todos e todos são iguais e livres ${ }^{49}$ :

que Deus jamais concedeu a alguém semelhante domínio privado, dado que é mais sensato considerar que Deus, que determinou à humanidade crescer e multiplicar-se, teria, antes, concedido a todos um direito de fazer uso do alimento, do vestuário e outras comodidades da vida de cujos materiais ele os proveu com tal abundância, e não fazê-los dependentes, para sua subsistência, da vontade de um homem com o poder de aniquilar a todos [...] provável que os submetesse, a seguir, ao serviço árduo por meio da necessidade e da dependência de uma escassa fortuna, do que promovesse, por meio de uma liberal concessão das comodidades da vida, o grande desígnio de Deus, crescei e multiplicai-vos (LOCKE, 2005, I, 41).

Evidencia-se, na presente passagem, o homem enquanto ser livre e igual e todos com o mesmo direito a tudo que houver na natureza para sua subsistência, para se preservar e preservar a humanidade. Como criatura de Deus, torna-se propriedade d'Ele e, ao mesmo tempo, senhor de si mesmo, face à ausência de qualquer tipo de subordinação entre os homens. A ausência de subordinação e de dependência é a marca indelével nos seres criados à imagem e semelhança de Deus. Sobretudo, Locke quer demonstrar que a igualdade atribui aos homens as mesmas vantagens e, na eventualidade de alguém estar em condições materiais superiores, isso não lhe atribui "vantagens" ou posição superior em relação aos demais.

A conjugar a ideia de liberdade natural com a citada passagem (LOCKE, 2005, II, 41), percebe-se que Locke, a par da questão da não subordinação, pretendia mostrar que se poderia viver no estado de natureza, inclusive com "relações" de posse, sem a necessidade da lei civil, apenas sob a lei da razão. Procura evidenciar que os homens possuem (possuíam), no estado

\footnotetext{
${ }^{49}$ Aqui, na análise da "relação natural de propriedade(s)", é extremamente importante lembrar que o ser humano livre para Locke é o ser de "razão e reflexão", que através do "conhecimento" pode ter o domínio de si, o controle da sua vontade. A liberdade é a marca distintiva dos homens, pois, na medida em que é dotado de razão, não está sob o arbítrio de outrem e nem sob o seu próprio (paixões ou desejos). A igualdade é inerente a essa condição. Todos são "filhos de Deus", livres e iguais. Iguais porque dotados da mesma faculdade: a razão.
} 
de natureza, os seguintes bens naturais: a vida, a liberdade, a igualdade (bens imateriais), os meios de prover a sua subsistência e os eventuais bens para esse fim (bens materiais). É através de tais bens que o homem racional irá cumprir o desígnio de Deus "crescei e multiplicai-vos" nos parâmetros da lei de natureza: preservar-se e preservar a humanidade.

Locke afirma ser próprio do homem, ou seja, sua propriedade, a vida, a liberdade e bens (posses). São direitos que os homens possuem no estado de natureza, anteriores à instituição da comunidade política, pois a conservação da vida impõe a busca de meios para esse fim. A regulamentação dessa busca dar-se-á nos ditames da lei de natureza, regulando, assim, o direito de propriedade.

Todo o Segundo Tratado encontra-se permeado pela expressão "propriedade", ora no singular, ora no plural ${ }^{50}$. Há que se ter como certo que

o termo "propriedade" tem, em Locke, dois significados mais explícitos. O primeiro, mais amplo, é a idéia de direito em geral, ou a soma dos direitos à vida, à liberdade, e aos bens materiais. O segundo, mais estrito, se reduz ao direito aos bens materiais. Não é difícil perceber o significado com o qual Locke opera nos vários momentos do seu discurso, mas prevalece, particularmente no capítulo 5 do Segundo Tratado sobre o Governo, a idéia de direito aos bens materiais (JORGE F., 1992, p. 77).

A leitura atenta da sua exposição sobre o estado de natureza leva à afirmativa de que a sociedade política objetiva a mútua conservação das propriedades - em sentido amplo -, face à máxima da lei de natureza: autopreservação e preservação da humanidade.

A principal ideia é a de que o "direito da humanidade aos produtos da natureza provém da concessão de Deus nas Escrituras, da racionalidade humana e da lei natural e fundamental da autopreservação (II, § 25 ss., I $§ \S 86$ e 87)” (LASLLET, 2003, p. 254).

Locke procura relacionar a origem da propriedade privada à autopreservação. Aqui, a par da idéia do todo - preservar a humanidade --, Locke permite ver a idéia de uma certa individualidade natural, pois mostra o homem como uma singularidade da obra divina -

\footnotetext{
${ }^{50}$ Apenas para citar alguns exemplos (LOCKE, 2005): II,57: “[...] mas uma liberdade para dispor e ordenar como se quiser a própria pessoa, ações, posses e toda sua propriedade [...]"; II, 87: “[...] o homem [...] tem ele por natureza o poder não apenas de preservar sua propriedade, isto é, sua vida, liberdade e bens contra injúrias [...]”; II, 123: "[...] projetam unir-se para a mútua conservação de suas vidas, liberdades e bens, aos quais atribuo o termo genérico de propriedade"; II, 124: "o fim maior e principal para os homens unirem-se em sociedades políticas [...] é [...] conservação de sua propriedade"; II, 209: "[...] e estes se convençam de que suas leis, e com elas seus haveres, liberdades e vidas, correm perigo [...]"; II, 222: "a razão pela qual o homem entra em sociedade é a preservação de sua propriedade [...]".
} 
indivíduo -, algo individualizado com vida, liberdade e bens. E cada um a seu tempo utiliza a faculdade diferenciadora da razão para preservar-se e preservar a humanidade.

Não há aqui qualquer alusão a um ser egoísta. Locke refere-se ao gênero humano, permitindo entrelaçar o homem enquanto espécie, com as mesmas vantagens e direitos a tudo quanto existe na natureza (e faculdades), para melhor benefício da vida (LOCKE, 2005, II, 25), e o homem enquanto individualidade (razão e reflexão a agir sobre a natureza).

É importante, no seu "sistema de propriedade", registrar a relevância das condições naturais do homem - a igualdade, a liberdade e o comunismo original -, pois é a partir de tais premissas que se extrai que o homem "enquanto espécie é que tem o direito de possuir essas tais coisas", e não o "homem enquanto indivíduo" 51 . Logo, "isso significa que os produtos da natureza eram originariamente de posse comum, tanto porque a Bíblia o afirma, como porque a igualdade e a liberdade universais devem significar o comunismo original" (LASLLET, 2003, p. 254).

Locke mostra, primeiramente, um "comunismo original", afirmando que Deus deu o mundo aos homens em comum. Todos os frutos e animais (inclusive a terra) são comuns a toda a humanidade, uma vez que foram produzidos pela própria "mão espontânea da natureza"; foram criados para uso do homem, ou seja, "a terra, e tudo quanto nela há, é dada aos homens para sustento e o conforto de sua existência" (LOCKE, 2005, II, 26). Desta forma, aduz que:

Quer consideremos a razão natural - que nos diz que os homens, uma vez nascidos, têm direito à sua preservação e, portanto, à comida, bebida e a tudo quanto a natureza lhes fornece para sua subsistência - ou a revelação - que nos relata as concessões que Deus fez do mundo para Adão, Noé e seus filhos -, é perfeitamente claro que Deus, como diz o rei Davi (S1 115, 61), deu a terra aos filhos dos homens, deu-a para a humanidade em comum (LOCKE, 2005, II, 25).

Neste ponto é que Locke levanta a reflexão de que, "por terem sido essas coisas dadas" para uso em comum, "é, contudo, necessário" que exista "um meio de apropriar parte delas de um modo ou de outro para que possam ser de alguma utilidade ou benefício para qualquer homem em particular" (LOCKE, 2005, II, 26).

\footnotetext{
${ }^{51}$ No que toca à propriedade, há que se admitir que "o uso desta palavra por Locke é bastante curioso, assistemático, mas de certa importância. [...] o termo 'propriedades' aparece com frequência, muitas vezes em associação à 'qualidade' [...] as propriedades pertencem a 'espécies, não a indivíduos"” (YOLTON, 1996, p. 212).
} 
A preocupação é evidente: legitimar a propriedade privada - a apropriação entre os iguais -, sem ferir a própria igualdade, sem que a condição de ter ou deixar de ter algo material possa arranhar o princípio da igualdade e o comunismo originário.

Locke optou por uma solução coerente com a condição do homem: ser livre e senhor de si e de seus atos. O fato de ser cônscio e responsável por suas ações implica ter direitos e obrigações nas suas esferas de relações, implica viver de acordo com a lei de natureza.

Assinalar direitos e obrigações é algo muito importante neste sistema. Atribuir a condição (direito) de liberdade ao homem implica mostrá-lo como senhor de si: proprietário de sua própria pessoa. O homem como ser livre e racional é senhor de si. Tem um valor diferenciado na criação divina, pois foi criado à imagem e semelhança de Deus. A partir dessa premissa é que Locke constrói sua teoria da propriedade privada. A preservação de si e da humanidade requer a utilização racional do que Deus criou: a apropriação da natureza deve ocorrer nos termos da lei de natureza.

O raciocínio lockiano quer ser prático e coerente com sua crença em relação à finalidade do homem. A percepção de si como ser livre e racional, notadamente, implica conhecimento de si e autocontrole, o que por sua vez implica ser "senhor de si": proprietário de si mesmo. O homem livre não está sujeito a nenhum outro e, também, a nenhum desejo ou paixão desenfreada. Por isso Locke afirma que a primeira propriedade do homem é a da sua própria pessoa:

Embora a terra e todas as criaturas inferiores sejam comuns a todos os homens, cada homem tem uma propriedade em sua própria pessoa. A esta ninguém tem direito algum além dele mesmo. O trabalho de seu corpo e a obra de suas mãos, pode-se dizer, são propriamente dele (LOCKE, 2005, II, 27).

Tal afirmação é ponto crucial na argumentação lockiana, pois a "única propriedade privada original é para Locke a que cada um guarda de sua própria pessoa, sobre a qual "ninguém tem o direito, só ele mesmo"” (RAYNAUD, 1993, p. 682) . Desta forma, "podemos dizer que a primeira propriedade é a pessoa, com sua liberdade, seus talentos, seu trabalho, que tornará possível a saída de si mesma rumo ao mundo exterior” (NASCIMENTO, 2001, p. 1340). 
Locke vai mais além, ao acrescentar a relação do homem com o meio natural, a transformação da natureza através do trabalho ${ }^{52}$. E a partir desta consciência de subjetividade e do agir humano com um fim específico é que passa a explicar a origem da propriedade privada, apresentando-a como algo derivado da atuação do homem sobre a natureza, na busca da conservação de si, da sua vida e liberdade.

Aqui, Locke relaciona o todo (coisas em comum) com o homem singular (individual) e a "coisa em particular" através de uma ação sua: "um meio de se apropriar":

Qualquer coisa que ele então retire do estado com que a natureza o proveu e deixou, mistura-a ele com o seu trabalho e junta-lhe algo que é seu, transformando-a em sua propriedade. Sendo por ele retirada do estado comum em que a natureza a deixou, a ela agregou, com esse trabalho, algo que a exclui do direito comum os demais homens. (LOCKE, 2005, II, 27)

A propriedade surge com a ação do homem sobre a natureza, ou seja, o que legitima a apropriação de bens úteis e necessários ao homem é o trabalho. Este agir sobre a natureza transforma "a coisa" em sua propriedade, surgindo a "propriedade privada" e, consequentemente, a noção do que seja a propriedade coletiva e a particular. Nas palavras de Amaury Cesar Moraes, por ser "natural o direito do homem sobre o seu corpo, decorre daí a 'naturalidade' do direito do homem sobre as coisas que ele adquire com seu corpo, como o trabalho de seu corpo. Essa é a primeira legitimação da propriedade" (MORAES, 2007, p. 79).

Locke procura ser didático na explicação da relação de apropriação de tudo quanto existe na natureza (a terra e tudo que nela há). Argumenta que, originariamente, não há um domínio particular sobre as "coisas existentes", tudo está voltado para o sustento e conforto do homem. Todavia, conclui por uma "permissão" natural para que se possa apropriar de parte dessas coisas para melhor benefício do homem. Logo, pode o ser humano ter uma propriedade daquilo (ou parte daquilo) que Deus, originariamente, deu em comum a todos.

\footnotetext{
${ }^{52}$ A expressão lockiana da "propriedade em sua própria pessoa" apresenta algo interessante e peculiar: o homem se reconhece como pessoa - sujeito de direitos, como um ser diferenciado. Para Locke, "nascemos homens podemos nos tornar pessoas", através do uso apropriado da razão e acatamento à Lei de Natureza, que seria o aspecto moral, que faz com que o homem possa refletir sobre si mesmo, que se reconhece como um ser singular no tempo e no espaço, que é capaz de perceber-se como responsável por suas ações passadas, bem como refletir sobre suas ações futuras. A partir de quando o homem começou a se perceber como uma individualidade no tempo e no espaço começou a se definir o conceito de pessoa, talvez uma construção paulatina na história do homem. Locke enfatiza a "identidade do eu", a consciência que se tem de si mesmo, concebe "pessoa" como o nome para o "eu", sendo um "termo forense que adequa as acções ao seu mérito e, portanto, pertence apenas aos seres inteligentes, capazes de uma lei e da felicidade e do sofrimento. Esta personalidade estende-se para além da existência presente em direcção ao que é passado unicamente através da consciência, por ela é responsabilizada e acaba por ser afectada; detém e imputa a si acções passadas, baseando-se apenas no mesmo princípio e pela mesma razão com que o faz em relação às acções do presente" (LOCKE, 2008, p. 459).
} 
Preocupa-se, assim, em mostrar uma ação do homem em relação às "coisas em comum". O ato de caçar, pescar e colher "destacam" a coisa da natureza (do todo), agregando-a ao homem:

O fruto ou a caça que alimenta o índio selvagem, que desconhece o que seja um lote e é ainda possuidor em comum, deve ser dele, e de tal modo dele, ou seja, parte dele, que outro não tenha direito algum a tais alimentos, para que lhe possa ser de qualquer utilidade no sustento de sua vida (LOCKE, 2005, II, 26).

aquele que se alimenta das bolotas que apanha debaixo de um carvalho ou das maçãs que colhe nas árvores do bosque com certeza delas apropriou-se para si mesmo. Ninguém pode negar que o alimento lhe pertença (Ibid., II, 28).

Locke toma o cuidado de discutir o momento em que tais "coisas" passam a the pertencer: se quando colheu, caçou ou pescou, quando levou para casa, ou, ainda, quando comeu. A resposta é clara: "se o fato de colher o alimento não o faz dele, nada mais o faria" (LOCKE, 2005, II, 28). Isso por que:

Aquele trabalho imprimiu uma distinção entre esses frutos e o comum, acrescentando-lhes algo mais do que a natureza, mãe comum de todos, fizera; desse modo tornaram-se direito particular dele (LOCKE, 2005, II, 28).

Na questão do "momento da apropriação", Locke expõe seu entendimento de que a apropriação não depende do consentimento expresso dos membros da comunidade, reforçando que o "pasto em que meu cavalo comeu" ou a "relva que meu servidor cortou", ou ainda, "o minério que retirei da terra em qualquer lugar onde eu tenha um direito a ele em comum com outros homens tornam-se minha propriedade, sem a cessão ou o consentimento de quem quer que seja" (LOCKE, 2005, II, 28). Nessa linha, a extensão de terra, na qual o homem pode "arar, plantar, melhorar, cultivar e os produtos dela que é capaz de usar constituem sua propriedade", pois, com o seu trabalho, o homem "delimita para si parte do bem comum" (LOCKE, 2005, II, 32).

Aqui, Locke evidencia duas importantes situações relativas à propriedade privada: a própria terra, a propriedade privada por excelência, e os limites da apropriação. Permite-se, dessa forma, através do trabalho "cercar" porções de terras até então comuns tornando-as terra particular de determinada pessoa ${ }^{53}$. Esse direito advém de seu esforço, de seu trabalho,

\footnotetext{
${ }^{53}$ Embora esse ponto demandasse séria reflexão, Locke deixa claro que o escravo "não participa do direito à propriedade, mas contribui para a "ampliação do patrimônio de seu senhor". Da mesma forma, Locke tem como
} 
atribuindo valor a um "pedaço de terra". Pois, segundo explica, Deus deu o mundo à humanidade, determinando ao homem que o trabalhasse, bem como a "penúria" de sua situação assim exigia. A conclusão é lógica: Deus e a razão impuseram a dominação da Terra e o melhoramento desta para "benefício da vida". Assim:

Aquele que, em obediência a essa ordem de Deus, dominou, arou e semeou qualquer parte dela, acrescentou-lhe com isso algo que era de sua própria propriedade, ao que os demais não tinham qualquer título, nem poderiam tomar-lhe sem causar-lhe injúria (LOCKE, 2005, II, 32).

Na concepção teológica lockiana, o homem deve cumprir a tarefa determinada aos homens: "O Senhor Deus tomou o homem e o colocou no jardim de Éden para cultivar e guardar" (Gênesis 2, 15). Para esse mister, o homem deve agir racionalmente, deve trabalhar, pautando suas ações conforme a lei de natureza. Assim, a apropriação requer trabalho, sendo este o "princípio que deu o direito de propriedade" (LOCKE, 2005, II, 45).

Trabalhar a terra, cultivar e produzir alimentos para preservar-se e à humanidade é cumprir o desígnio do Senhor Criador de todas as coisas. Como observa Raymond Polin, para Locke "o trabalhar a terra" não é uma "maldição", não obstante a "sentença bíblica": "ganhar o pão com o suor de seu rosto". Eis a "originalidade" de Locke, para quem o homem deve trabalhar mesmo no estado de abundância, fundamentando a sua tese da relação trabalho e propriedade, independentemente da "maldição divina", pois o trabalho pode ser exercido sem ser considerado "um castigo" (POLIN, 1960, p. 262).

A par disso, Locke utiliza as expressões "daquilo que é capaz de usar" e "melhoramento para benefício da vida", estabelecendo que as "coisas dadas em comum" são dadas para que sejam usufruídas para a vantagem da vida, ou seja, na medida da necessidade de cada um. Nas suas palavras:

Tanto quanto qualquer pessoa possa fazer uso de qualquer vantagem da vida antes que estrague, disso pode, por seu trabalho, fixar a propriedade. O que quer que esteja além disso excede sua parte e pertence aos outros. Nada foi feito por Deus para que o homem estrague ou destrua. [...] mantendo-se nos limites fixados pela razão do que poderia servir para uso, pouco espaço haveria para querelas ou contendas acerca da propriedade assim estabelecida (LOCKE, 2005, II, 31).

\footnotetext{
legítima a "apropriação" do trabalho alheio. No que toca ao servo - trabalhador -, por ser livre, realiza um contrato com o "senhor", prestando-lhes serviços, por tempo e condições determinados, "em troca de salário". Logo, "o produto de seu trabalho se acrescenta à propriedade do senhor, conforme os termos do contrato. Não é, portanto, o trabalho direto de um indivíduo a fonte exclusiva da propriedade, pois o produto do serviço por ele contratado pertence-lhe igualmente" (JORGE FILHO, 1992, p. 86). Ao que parece, a "utilização" do trabalho alheio facilita a "acumulação", a "apropriação de lotes de terras mais extensos" para o cultivo. Mas Locke está sempre atento a estas questões: a terra cultivada fornece alimentos, é útil (benefício de vida) ao homem e à humanidade (LOCKE, 2005, II, 40-43).
} 
Para Locke, o vínculo entre o homem e a propriedade ocorre numa certa relação de harmonia no estado de natureza. O direito exclusivo - propriedade privada - convive com o direito inclusivo: direito de todos aos meios que lhe possam propiciar a conservação de si e da humanidade (da vida), podendo também exercê-lo (reivindicar sua parte em relação às coisas comuns), pois:

Tampouco seria essa apropriação de qualquer parcela da terra, mediante a melhoria desta, prejudicial a qualquer outro homem, uma vez que restaria ainda bastante e de boa qualidade, e mais do que poderiam usar os que ainda não possuíam lote. De modo que, na verdade, nunca houve menos para os outros pelo fato de ter ele delimitado parte para si, pois aquele que deixa para outro tanto quanto este possa usar faz como se não houvesse tomado absolutamente nada de ninguém (LOCKE, 2005, II, 33).

O início do capítulo V do Segundo Tratado deixa isso claro ${ }^{54}$. Com efeito, Locke inicia-o trazendo a lume os principais direitos naturais e inclusivos do homem (direito à preservação, logo, à bebida, comida e tudo o mais existente na natureza para sua subsistência). Esta é a premissa de seu "estudo", pois Deus deu o mundo aos homens em comum e "a razão natural ensina que cada homem tem direito às coisas que a natureza oferece para sua subsistência" (TULLY, 1982, p. 95).

Locke toma como certo que Deus não fez o mundo para deixá-lo "inculto", dando-o para o uso diligente e racional, e que "o trabalho haveria de ser o título da propriedade". E, feito o mundo para ser "melhorado através do trabalho" para maior benefício e conveniência da vida, e "não para a fantasia e a cobiça dos rixentos e litigiosos", ninguém precisaria "queixar-se nem deveria meter-se" com as "porções de terra" que já estivessem melhoradas. Ora, "caso o fizesse, ficaria claro que desejava o benefício dos esforços alheios, ao qual não tem direito, e não ao solo que Deus lhe dera em comum com outros para trabalhar [...]" (LOCKE, 2005, II, 34). Aqui fica clara a sua diretriz em relação à apropriação de bens materiais: uso diligente e racional das coisas existentes e o esforço próprio. Repudia o desperdício e a ociosidade, pois a própria natureza já fixou a medida da propriedade pela "extensão trabalho" e pela "conveniência da vida" do ser humano (LOCKE, 2005, II, 36).

Sobressai daí que a ninguém é dado apropriar-se de porção maior que possa trabalhar ou que seja de conveniência da vida. Seguir essa regra significa que não se desfrutaria mais do

\footnotetext{
${ }^{54}$ Ora, Locke afirma que, "ainda no mundo", todo homem poderia ter seu "quinhão de terra" para bem cultivar, "sem constranger ninguém", pois que "existe muita terra no mundo". Todavia, a "posse ampliada", com a invenção do dinheiro, por consentimento do próprio homem, modificou as relações naturais de propriedade, acarretando a "instituição do estado civil e da lei positiva" (LOCKE, 2005, II, 36), como se verá à frente.
} 
que uma "pequena parte" e, também, que não seria possível usurpar eventuais direitos de outrem ou "adquirir propriedade em prejuízo do vizinho". Nas palavras de Locke:

tal medida confinava a posse de cada homem a uma proporção bastante moderada, tanto quanto ele pudesse apropriar-se para si sem causar injúria a quem quer que fosse, nas primeiras eras do mundo [...] (LOCKE, 2005, II, 36).

Locke impõe aqui um limite-regra para a apropriação: cada homem dever ter tanto quanto possa usar sem causar prejuízo a outrem. E afirma que tudo poderia estar seguindo essa primeira regra da propriedade, caso não houvesse ocorrido a "invenção do dinheiro", bem como o acordo tácito dos homens atribuindo-lhe um valor e introduzindo, por consenso, “posses maiores e um direito a estas" (LOCKE, 2005, II, 36) ${ }^{55}$.

A regra do não "desperdício da apropriação" para não ofender direitos alheios, que impedia a "acumulação" cedeu lugar à relação monetária. A instituição do dinheiro, um instrumento durável, passível de ser guardado sem estragar, modificou a relação de "troca", bem como "resolveu" a questão da "acumulação". Os homens, "por consentimento mútuo", aceitaram o dinheiro "em troca dos sustentos da vida, verdadeiramente úteis, mas perecíveis" (LOCKE, 2005, II, 47).

Locke era avesso ao desperdício e ao luxo, bem como à apropriação ilimitada, pois são práticas que se chocam com os ditames da lei de natureza - virtude moral. Condutas guiadas pelo autointeresse são contrárias à razão, abolindo a "confiança" necessária entre os homens, negando a lei fundamental de natureza ${ }^{56}$. Para Locke, a verdadeira medida é a lei de natureza. Tal entendimento leva a crer que a "apropriação ilimitada" não é uma relação natural. Tanto não é que a partir daí é que houve a "instituição do estado civil”. Nesse sentido:

portanto, julgamos não concordarem entre si a ampliação da propriedade e a lei de natureza, que prescreve o limite de utilidade. Se o consentimento ao uso do dinheiro introduz [...] "por consentimento, maiores posses e um direito a elas..." (II, 36), a nosso ver não se trata aqui de um direito natural, mas apenas de um direito instituído, a ser respeitado como obrigação

\footnotetext{
${ }^{55}$ Locke fala de uma "evolução" até a convenção que estabeleceu o valor do dinheiro. Explica que aquele que colheu maçãs tornou-se proprietário destas, tendo que cuidar para não perecer, pois se isso ocorresse "estaria roubando parte alheia". Assim, se cedesse parte a uma outra pessoa estaria cuidando para que não houvesse desperdício. Também, poderia trocar "ameixas" que poderiam estragar por "nozes", alimento mais durável, que o poderia alimentar por um ano. Esta troca não traria "dano a ninguém". Todavia, se "trocasse suas nozes por um pedaço de metal cuja cor lhe agradasse, ou sua lenha por uma pedra brilhante ou um diamante, e as guardasse consigo por toda vida, não estaria invadindo direito alheio e poderia acumular tantas dessas coisas duráveis quanto lhe aprouvesse; o exagero nos limites de sua justa propriedade não residia na extensão de sua posses, mas no perecimento inútil de qualquer parte delas" (LOCKE, 2005, II, 46).
}

${ }^{56}$ Ensaios VIII: “A base da lei de natureza é o interesse próprio de cada homem? Não” (LOCKE, 2007, p. 158). 
convencional pelos que a ele consentiram, mas não obrigatoriamente pelos demais (JORGE FILHO, 1992, p. 94).

A convenção "sobre o dinheiro mudou o mundo", modificou as relações naturais de propriedade, uma vez que se passou a concordar também com a posse desigual e desproporcional das terras. Veio-se a permitir que alguém possa ter "com justiça mais terra que aquela cujos produtos possa usar, recebendo em troca do excedente ouro e prata que podem ser guardados sem prejuízo de quem quer que seja, uma vez que tais metais não se deterioram nem apodrecem nas mãos de quem os possui”" (LOCKE, 2005, II, 50). Daqui a sua famosa frase, já assinalada:

Portanto, no princípio, o mundo inteiro era a América, ainda mais que hoje, pois nada semelhante ao dinheiro era conhecido em parte alguma. Descubrase qualquer coisa que tenha o uso e o valor do dinheiro entre os vizinhos e ver-se-á que o mesmo homem começará logo a ampliar suas posses (LOCKE, 2005, II, 49).

Locke deixa claro que a legitimidade da propriedade pelo trabalho, a troca de excedentes, o uso tácito do dinheiro e a "desigualdade da propriedade" iniciaram-se no estado de natureza, ou seja, "fora dos limites da sociedade e sem um pacto". Mas afirma também ser natural apenas a posse das coisas necessárias e úteis aos benefícios à vida. A regra natural é o uso sem desperdício e a apropriação limitada. Vale a pena voltar à seguinte passagem:

[...] uma coisa ouso afirmar: que a mesma regra de propriedade segundo a qual cada homem deve ter tanto quanto possa usar estaria em vigor no mundo, sem prejuízo para ninguém, conquanto há terra bastante no mundo para o dobro dos habitantes, se a invenção do dinheiro e o acordo tácito dos homens no sentido de lhe acordar um valor não houvesse introduzido (por consenso) posses maiores e um direito a estas (LOCKE, 2005, II, 36).

No princípio, então, o trabalho legitimava a propriedade e esta possuía determinados limites. O direito e a conveniência andavam lado a lado, posto que o homem somente "tinha direito a tudo em que pudesse empregar seu trabalho, e por isso não tinha a tentação de trabalhar para obter além do que pudesse usar" (LOCKE, 20050, II, 51) ${ }^{57}$. Disso resulta uma observação muito importante: a legitimidade da propriedade advém única e exclusivamente de seu uso em conformidade com a lei de natureza. A ação do homem - seu trabalho - conforme as regras naturais é que legitima a propriedade, pois "a natureza fixou bem a medida da

\footnotetext{
${ }^{57}$ Limites e restrições são as palavras-chave lockianas em relação à apropriação, pois posses e acumulações ilimitadas, bem como "consumismo desenfreado", colocam em risco não só as próprias pessoas como "gerações futuras", contrariando a lei de natureza. Ora, Locke não parecia nada simpático ao luxo e ao desperdício, e sim à "vida frugal e simples. E respalda a idéia de uma limitação da esfera de utilidades, que envolve as necessidades de subsistências, bem como as conveniências da vida" (JORGE FILHO, 1992, p. 107).
} 
propriedade pela extensão do trabalho e da conveniência de vida dos homens" (LOCKE, 2005, II, 36).

Locke quer passar a ideia de que o trabalho do homem não poderia significar a dominação ou a apropriação "de tudo nem poderia o seu desfrute consumir mais que uma pequena parte" (LOCKE, 2005, II, 36). As relações entre os homens, sob essa diretriz, "não deixava espaço para controvérsia acerca do título nem para a violação do direito alheio", pois tudo que o homem tomava para seu uso era para seu sustento, sendo "facilmente visível e seria inútil, bem como desonesto, tomar demasiado, ou mais do que o necessário" (LOCKE, 2005, II, 51).

Nosso autor encerra a sua reflexão sobre a propriedade deixando entrever que, possivelmente, contendas surgiram em relação a essa nova forma de apropriação, trazendo inconvenientes à convivência no estado de natureza. Fica claro, no capítulo V do Segundo Tratado, uma séria correspondência entre a "complexidade econômica e o desenvolvimento das formas de propriedade". E "isso altera as relações entre os homens, multiplicando as ocasiões de conflito e tornando indispensável a instituição do juiz comum" (KUNTZ, 2004, p. 110-111).

Ora, as relações se tornaram complexas, a lei de natureza nem sempre respeitada e a precariedade da aplicação da estranha doutrina tornaram necessária a centralização do poder de repressão. O processo de apropriação modificou-se, tornando-se complexo e o dinheiro passou a "comandar o mundo da troca mercantil, sem mais nenhuma referência ao mundo do trabalho" (NASCIMENTO, 2001, p. 1340) ${ }^{58}$. O “desejo de ter mais que o necessário" instalou-se fortemente e a solução encontrada foi optar, racionalmente, pelo estado civil, na expectativa de uma possível mudança nas novas relações convencionais. Assim, em cena

[...] entra o papel do governo, do juiz do poder comum, necessário para repor em seu lugar o mundo que escapa pelos dedos, ou seja, encontrar nele ainda um lugar para o trabalho como determinante do valor das mercadorias (NASCIMENTO, 2001, p. 1340).

\footnotetext{
${ }^{58}$ A lei de natureza asseguraria a posse pacífica dessas "coisas", já que não é dado a ninguém prejudicar a outrem, como visto. Entender a relação de posse em Locke não é tarefa fácil. Num primeiro momento, temos os homens livres e iguais que buscam o prazer e fogem da dor. Isso poderia trazer "um certo tom" de egoísmo e espaço individualista. Mas isso não ocorre na visão lockiana, pois os homens não são "agentes atomizados", "a independência natural consiste simplesmente na relação igual entre os indivíduos, sem subordinação regular" e, sobretudo, a "independência não deve ser entendida como um isolamento e muito menos como guerra de todos contra todos" (KUNTZ, 2004, p. 111). O homem sensação e reflexão lockiana, no que toca à sua liberdade, vida e posses - propriedades - possui obrigações e direitos face à máxima "conservar a si e conservar a humanidade", com intensa interação individual e coletiva.
} 
A conclusão pela "instituição do governo civil" é algo inevitável face aos possíveis inconvenientes que podem surgir no estado de natureza ${ }^{59}$. "Pode ser difícil" determinar com precisão "uma fronteira entre os dois estágios, determinar o momento da passagem do estágio natural ao estágio político. Apenas pode-se precisar que, como assinala Rolf Kuntz, “a criação do governo responde a uma exigência criada pela vida coletiva, num determinado nível de complexidade" (KUNTZ, 2004, p. 111).

Locke forçou-se a refletir sobre certa dificuldade em se viver neste estado natural. O nível de complexidade das relações entre os homens e a "estranha doutrina" de que os homens, no estado de natureza, possuem o poder executivo da lei - são juízes em causa própria (LOCKE, 2005, II, 9 e 13) - são questões delicadas a repensar a manutenção deste estado.

As relações entre os homens envolvendo suas propriedades, na medida em que se tornaram complexas, impuseram a necessidade do poder político, o qual Locke definiu como o direito de editar leis, visando regular e preservar a propriedade (LOCKE, 2005, II, 3).

Locke parecia, sinceramente, acreditar que todo homem tem direito a sua subsistência e que o trabalho era algo importante para dignificar o homem. Além disso, em momento algum considera natural a desigualdade econômica entre os homens. Talvez a sua teoria da propriedade (em sentido estrito) - como todo o Segundo Tratado, referindo-se à propriedade em sentido amplo - mostre o seu "desejo de negar o direito, por parte de um monarca reinante, de fazer o que quisesse com as posses de seus súditos, sem o seu consentimento" (DUNN, 2003, p. 60).

O Segundo Tratado refere-se às propriedades em sentido amplo (vida, liberdade, igualdade e outras posses materiais). O objetivo seria frisar que as propriedades do ser humano, sejam materiais ou imateriais, devem ser respeitadas pelo poder político. Por isso é que, Locke ao admitir a necessidade da instituição do poder civil, afirma que os homens uniram-se em sociedade:

para a mútua conservação de suas vidas, liberdades e bens, aos quais atribuo o termo genérico de propriedade (LOCKE, 2005, II, 123).

\footnotetext{
${ }^{59}$ A “introdução do dinheiro cria um mercado que opera naturalmente ou com uma mão invisível”, e para Locke as relações sociais conduzem naturalmente a uma sociedade justa somente quando ausente o dinheiro. O dinheiro rompe com essa ordem natural e o governo é obrigado a "continuar uma nova ordem de relação" para recolocar as ações dos homens, uma vez mais, em sintonia com a vontade de Deus (TULLY, 1982, p. 154).
} 
O próprio Locke consignou que para evitar o "apelo aos céus" - o estado de guerra necessário será o governo, "remédio para os inconvenientes" do estado de natureza. Surge aqui a questão sobre a passagem do estado de natureza para o estado civil. Mais ainda, sobre que tipo de governo pode substituir a liberdade natural e a "estranhíssima doutrina". Tais questões são importantes para a delimitação da legitimidade do poder - "da autoridade e da submissão política". Algumas reflexões a mais sobre a condição natural do homem, precisamente, sobre a "relação natural" no estado de natureza, poderão nos apontar a resposta para tais questões.

\subsection{Paz e Guerra: as relações naturais}

A condição natural do homem envolvia um todo complexo: pessoas, famílias e posses em relações várias. O que é importante frisar é a ausência de um poder comum e de uma lei escrita, prévia e conhecida. A necessidade do poder comum advém da complexidade das relações que vão se intensificando e, as relações de posse e as "monetárias" - relações socioeconômicas - tiveram grande participação nesse acontecimento ${ }^{60}$.

Talvez por isso Locke tenha afirmado que "no início 'all the world was America",, referindo-se à "evolução" da complexidade das relações humanas que passam a exigir um "ordenamento" diferente do existente no estado de natureza. Isso porque o estado de natureza já é um estado “de intensas relações”, governado pela razão e pela lei natural.

O estado de natureza lockiano tem ensejado críticas. Foi denominado por Macheperson como "uma curiosa mistura de imaginação histórica e abstração lógica da sociedade civil" (MACPHERSON, 1979, p. 210). Este autor visualiza a seguinte contradição:

\footnotetext{
${ }^{60}$ Locke afirmou que Deus fez o homem "com forte inclinação à sociabilidade". O fato de ser uma inclinação não significa que a sociabilidade seja essencial, e sim ligada à liberdade humana conjugada com sua "obrigação racional". Assim, "Deus fez o homem para que ele seja um indivíduo sociável, mas deixou à sua liberdade a tarefa de realizar ou não sua individualidade, de concretizar ou não sua sociabilidade". Ora, a individualidade e a sociabilidade e todas as consequências destas são obrigações essenciais aos homens, "exigências de ordem moral". Pois "só seres livres e racionais podem ser indivíduos sociáveis nesse sentido. Se eles não o conseguem, não alcançam tampouco ser homem" (POLIN, 2003, p. 163-164).
} 
o estado de natureza lockiano ora se apresenta como contrário ao estado de guerra, ora se assemelha ao mesmo. Na sua crítica, Macpherson assinala que, quanto mais Locke descreve o estado de natureza como algo "inseguro, instável e cheio de incerteza quanto ao gozo dos direitos individuais - expostos à invasão alheia - temores e perigos contínuos [...]" ((MACPHERSON, 1979, p. 251), mais o torna indistinguível do estado de guerra.

Para ele, Locke "tende a mostrar" que os homens seriam ou poderiam ser governados pela razão, podendo viver juntos independentemente de um governo comum. Todavia, admite que a existência de homens que "não seguem a lei da razão" dificulta essa possibilidade. Mas a questão é que a descrição feita por Locke desses homens "nocivos e degenerados" que abandonaram os Princípios da Natureza Humana "torna evidente que ele quer que seus leitores os vejam como sendo umas poucas exceções. A extravagância de sua linguagem poderia ser interpretada como a querer dizer que Locke estava ansioso para se convencer a si próprio da predominância da decência do estado de natureza" (MACPHERSON, 1979, p. $251)^{61}$.

Ao tecer considerações sobre a possível ambiguidade do estado de natureza lockiano e sobre o caráter pacífico ou não deste estado, Yara Frateschi comenta que, primeiramente, Locke o caracteriza como um estado de perfeita harmonia, inclusive com críticas aos que "confundem" o estado de natureza com o estado de guerra. Depois, a autora observa que Locke vem a caracterizá-lo como "inseguro", mas isso não significa ambiguidade, pois esta desaparece ao se perceber que Locke descreve "dois estágios" no estado de natureza: "um mais pacífico e outro menos", sendo que a passagem de um para o outro apresenta como marco a invenção do dinheiro, pois "o direito de propriedade, assim como a convenção que dá origem ao dinheiro [...] ocorreram no estado de natureza [...] e a partir daí surgem controvérsias que não podem ser resolvidas sem violência no estado de natureza, pois este carece de leis positivas e juízes com autoridade para fazer valer a sua sentença e resolver os conflitos" (FRATESCHI, 2008, p. 333).

\footnotetext{
${ }^{61}$ Macheperson, na sua crítica sobre o ambíguo estado de natureza lockiano, observa que se acostumou a pensar no homem natural - modelo apresentado por Locke - "como um ser essencialmente racional e social". Racional: podem viver juntos, governados pela lei de natureza - guiados pela razão. Social: podem viver juntos, em conformidade com a lei de natureza, sem a imposição de normas de um soberano. Todavia, Locke, assim como Hobbes, no que toca à natureza humana, sustentava que "os homens são motivados principalmente por apetites e aversões; e que os apetites são tão fortes que, 'se fossem deixados a seu próprio impulso, levariam os homens à subversão de toda a moralidade. As leis morais são estabelecidas como bridão a esses desejos exorbitantes'. Costuma-se dizer que a diferença entre essa opinião e a de Hobbes é que Locke achava os homens capazes de impor normas a si próprios, por perceberem sua utilidade, sem instituir um soberano" (MACHEPERSON, 1979, p. 250-251).
} 
A existência ou não de uma possível ambiguidade em relação ao estado de natureza, em Locke, não nos afigura assim tão relevante. A lógica do jusnaturalismo exige que se apresentem problemas "insuperáveis" no estado de natureza justificando o abandono do mesmo, com a consequente necessidade da passagem ao estado civil. Logo, necessariamente, há que fazer uso de um desdobramento do "estado de natureza". Nas palavras de Pierre Manent:

[...] toda doutrina do estado de natureza e do contrato social tem necessariamente um momento hobbeseano - esse é também o caso de Rousseau -, já que somente um estado de guerra insuportável, um mal intolerável pode explicar que os homens entrem em acordo para abandonar um estado em que, em princípio, seus direitos floresciam. Mas esse "momento hobbeseano" não encontra saída na solução de Hobbes. Ao contrário, a solução lockeana pode ser considerada diretamente dirigida contra Hobbes (MANENT, 1990, p. 76).

O recurso ao "estado de guerra" e a "estranha doutrina" motivam a instituição política $^{62}$. Isso está claro. Mas há um problema na solução não autoritária para a submissão política, para a obediência civil: como se processa a condução pacífica e o "trust" lockiano? O homem natural, caracterizado pela "sociabilidade", talvez solucione isso.

Mas uma advertência é necessária. A condição natural do homem e as suas relações devem ser entendidas no seguinte contexto: a época de John Locke é a época em que "as teorias baseadas nos direitos naturais iriam ser os principais veículos da discussão de questões éticas pelo resto do século XVII" (TUCK, 2001, p. 37).

As teses circundando o poder político eram fundamentadas na teoria do direito natural, que extraía sua legitimidade na hipotética condição natural do homem. Ao argumento de que os direitos naturais dos homens são reivindicados a partir do "estado natural", deve-se somar outro, presente na obra lockiana: o estado de natureza aponta direitos e impõe deveres.

$\mathrm{Na}$ verdade, sob a lei de natureza, primeiro tem-se o dever, depois o direito. De fato, o estado de natureza, no conjunto de sua obra, nos impõe a reflexão sobre o "direito inclusivo" e o "exclusivo",63.

Locke afirma que a razão natural determina ao homem que, uma vez nascido, possui o dever de se conservar (e ao próximo, pois a vida é dádiva divina), logo possui o direito à sua

\footnotetext{
${ }^{62} \mathrm{Na}$ análise da distinção entre estado de natureza e estado de guerra, Pierre Manent observa que "foi preciso que Locke distinguisse um do outro, para evitar as conseqüências despóticas ou absolutistas da doutrina hobbeseana, para atribuir os direitos a um indivíduo realmente solitário" (MANENT, 1990, p. 75).

${ }^{63}$ Sobre esse assunto, ver James Tully (1982), em seu livro A Discourse on Property, com destaque aos capítulos 5 e 6: "Exclusive rights" (p. 95-130) e "Property and obligations" (p. 131-153), respectivamente.
} 
preservação e, como consequência, à comida, bebida e ao que houver na natureza para a sua subsistência (LOCKE, 2005, II, 25) ${ }^{64}$.

Ora, esse direito pertence a todos. Disso decorre a necessidade de se estabelecer regras para a convivência dos múltiplos direitos, o que implica em deveres para essa convivência. Há que se estabelecer a "convivência" dos direitos, surgindo os "deveres", pois todos têm direito à preservação. E a razão determina que o homem deve preservar a si mesmo e a toda a humanidade.

A abordagem lockiana do "estado de natureza" e das relações do homem natural inicia-se com reflexões citando o "judicioso Hooker", para quem os homens são iguais por natureza e "tudo que é igual deve receber a mesma medida", ou seja, se pratico o mal posso esperar receber sofrimento. Logo, "se espero ser amado devo amar". Assim, as máximas de justiça e caridade derivam da obrigação de amor recíproco entre os homens: deveres que têm uns para com os outros. A seguinte passagem é bem elucidativa:

o judicioso Hooker considera essa igualdade dos homens por natureza tão evidente por si mesma e acima de qualquer dúvida que a torna o fundamento da obrigação ao amor mútuo entre os homens, na qual faz assentar os deveres que estes têm uns com os outros, e da qual derivam as grandiosas máximas da justiça e da caridade (LOCKE, 2005, II, 5).

O estado de natureza lockiano é um estado de intensa sociabilidade, destacando-se a ausência de um poder civil comum. O homem natural conta com a lei de natureza, lei esta de “sentido forte", para utilizar aqui uma expressão de Rolf Kuntz.

Locke se refere ao estado em que todos os homens naturalmente "estão" (LOCKE, 2005, II, 4). O verbo utilizado por Locke não denota passado, mas procura apenas imaginar os homens, nas suas relações corriqueiras, sem a existência de uma ordem política a comandar suas ações.

\footnotetext{
${ }^{64}$ Direito à preservação e direito aos meios para garantir a sua preservação, não se nega. Mas a condição natural do homem é a vida em comunidade (social), e não isolado. Logo, há deveres para a "sustentabilidade" da "preservação", seja na condição natural ou política. Inclusive no que toca à propriedade - a posse de algo -, tema delicado na obra lockiana, pois Locke tece severas críticas ao desperdício e à acumulação desenfreada e inútil. É comum ligar a formalização da sociedade civil como meio para a proteção da propriedade em seu sentido estrito. E esta posse material seria a "particularidade" de conflito que impulsionaria o estado político. Todavia, a nosso ver, embora a propriedade esteja inserida nesse contexto, a questão maior é a relação entre o teu e o meu (como os homens vivem e convivem com os direitos e deveres na sociedade), ou seja, é a própria "relação" moral entre os indivíduos que deve ser melhor analisada, que implica na percepção do outro como um igual em direitos e deveres. Esta era uma preocupação de Locke, como se pode analisar nos Ensaios sobre a Lei de Natureza, e que o acompanhou nos seus escritos posteriores e, especificamente no escrito Alguns Pensamentos sobre a Educação.
} 
Robert A. Goldwin pondera que o estado de natureza lockiano "não se limita à condição pré-política, original do homem”, é "mais amplo do que uma descrição do homem antes do desenvolvimento da sociedade civil. É uma certa forma de relação humana; sua existência, quando existe, não tem nada a ver com o grau de experiência política dos homens que estão nele; e pode existir em qualquer época da história da humanidade, inclusive no presente [...] na América, um europeu (como o suíço mencionado por Locke), embora seja um homem político, encontra-se no estado de natureza" (GOLDWIN, 1996, p. 453-454).

Locke, para enfrentar aqueles que dizem que nunca houve um homem em estado de natureza, e visando afirmar que este é um estado de "vida em comunidade", cita o "judicioso Hooker",

para quem as leis de natureza obrigam os homens, embora não tenham tido qualquer camaradagem estabelecida, nem acordo solene entre si sobre o que fazer ou deixar de fazer, e por não sermos capazes de nos prover sozinhos do que precisamos, para suprir os defeitos e imperfeições em nós ao vivermos sozinhos, somos induzidos a procurar comunhão e camaradagem com outros indivíduos, por isso os homens começaram a unir-se em sociedade política (LOCKE, 2005, II, 15).

Os seus argumentos estão sempre voltados a interações entre os homens, ressaltando os elementos vontade e consentimento. Essas relações no interior da comunidade natural é que determinarão o poder político, pois o homem natural lockiano não aparece solto ou desligado de qualquer tipo de interação "social”. Ao contrário,

$\mathrm{Na}$ descrição lockiana, os indivíduos aparecem ou ligados a um grupo, ou à humanidade ou a Deus, mas nunca soltos num vazio moral. Esse dado é obscurecido pelo hábito, reforçado a partir de Macpherson, de associar Locke ao paradigma individualista. O sujeito lockiano está sempre subordinado a uma ordem que a idéia de comunidade ou sociedade humana fornece a Locke, uma ordem que transcende a individualidade. Por isso, a oposição estado civil-estado natural não corresponde à alternativa entre ordem legal e a atomização de agentes livres de qualquer norma, ou desobrigados de responder a qualquer autoridade" (KUNTZ, 2004, p. 102).

As relações morais são evidentes, independentemente da condição natural ou política do homem. Locke enfatiza que os homens podem fazer acordos e promessas entre si, conservando, todavia, o estado de natureza.

De fato, "As promessas e acordos de troca etc. entre dois homens numa ilha deserta [...] ou entre um suíço e um índio nas florestas da América" também os vinculam, não obstante estarem no estado de natureza entre si, pois a confiança e o dever de honrar a palavra 
dada são inerentes ao homem, independentemente de o mesmo ser ou não igualmente membro da comunidade política (LOCKE, 2005, II, 14) ${ }^{65}$.

O seu "experimento", o estado de natureza, não se limita a uma simples condição prépolítica original do homem, pois o seu homem natural não é pré-social ${ }^{66}$. Seus exemplos de homens na condição natural denotam uma "sociabilidade imanente", na medida em que possuem a sua própria organização e predisposição a firmarem acordos e cumprirem promessas.

Tais exemplos devem ser aceitos, não simplesmente para caracterizar o estado prépolítico (ausência de lei positiva e governo único), mas sim para referendar sua tese da liberdade-igualdade e consentimento, fornecendo subsídios à sua teoria da "submissão política".

O que Locke buscou esclarecer com o seu estado de natureza é que os homens são livres e iguais (direitos), vivem sob a égide da lei de natureza (obrigações) e que existem relações sociáveis entre eles. Sobretudo, procurou frisar que os homens se encontram, naturalmente, em estado de natureza e "nele permanecem até que, por seu próprio consentimento, se tornem membros de alguma sociedade política" (LOCKE, 2005, II, 15).

Locke inicia suas ponderações sobre o estado de natureza explicando que o faz porque é através deste que se pode descobrir os fundamentos do poder político. Além disso, é nesse estado que ressalta a característica prima do homem - liberdade e igualdade -.

A relação entre o estado de natureza e o estado de guerra, inserida na análise da “estranhíssima doutrina”, oportuniza o ingresso no estado político. Nesse raciocínio, Locke, como visto, concedeu um tratamento um tanto severo aos transgressores da lei de natureza, da paz social, colocando-os à margem da racionalidade, logo da vida social.

\footnotetext{
65 Talvez para suas futuras conclusões apresenta esses exemplos de acordos -promessas- cumprimento de palavras (valores morais e éticos), e articulando que todos os homens podem firmar "acordos", porém, não é qualquer pacto que faz cessar o estado de natureza, mas apenas a concordância mútua em formar uma comunidade estabelecendo um corpo político (II, 14).

${ }^{66}$ Segundo Norberto Bobbio, Locke, para desenvolver a sua teoria política, viu-se ante o seguinte dilema: de um lado Hobbes e seu estado de guerra, nada simpático aos teólogos, e de outro Pufendorf, para quem o estado natural é de paz, "embora de pobreza". Aceitar a teoria de Pufendorf implicaria na seguinte questão: "se o estado de natureza era um estado de paz, por que deveriam os homens mudá-lo?" (BOBBIO, 1997, p. 179). Locke procurou uma "solução de meio termo", que pode ser assim formulada "o estado de natureza não é, por si mesmo, um estado de guerra, mas pode tomar esse rumo" (Ibid, p. 179). Assim, embora não o seja atualmente, "o é potencialmente; que não é originariamente, mas pode transformar-se em estado de guerra, quando se torna difícil reconduzi-lo ao estado de paz original. [...] Em suma o estado de natureza não é essencialmente mau, mas apresenta inconvenientes. Ao percebermos, em certo ponto, que suas desvantagens superam as vantagens, tornase necessário abandoná-lo" (BOBBIO, 1997, p. 179).
} 
Talvez, esta tenha sido a sua saída para apresentar o primeiro momento do "direito de resistência" e permitir a autodefesa, seja qual for a situação (plano pré-político ou político, como se analisará à frente). Além disso, a forma não muito proporcional de defesa apresentada é um meio de justificar a possível necessidade de um juiz imparcial e da lei civil, evitando-se o uso da força - a subjugação entre os pares e o "apelo aos céus":

Evitar esse estado de guerra (no qual não há apelo senão aos céus, e para o qual pode conduzir a menor das diferenças, se não houver juiz para decidir entre os litigantes) é a grande razão pela qual os homens se unem em sociedade e abandonam o estado de natureza (LOCKE, 2005, II, 21).

Dessa forma, fica a questão se seria a própria condição natural do ser humano que explicaria as razões determinantes da instituição do poder político. Para Locke, os possíveis inconvenientes desse estado natural surgem dos que deixam de ouvir a razão (ou não querem, ou não podem, por falha ou problema da natureza), relegando a regra de que não se deve prejudicar a outrem na sua vida, saúde, posse e liberdade. A regra é a paz, a exceção são os que se desviam da "luz da razão". Aqui há dois pontos importantes:

- os homens são livres e iguais, logo, o poder político respeitará estes direitos prépolíticos, existentes anteriormente à criação do Estado - aqui, o ponto-chave é a liberdade versus a opressão;

- os homens são livres e iguais e suas relações podem apresentar alguns inconvenientes, v.g., a "estranha doutrina", daí a necessidade de um poder político a pautar essas relações - aqui, o ponto-chave é garantir ou retomar a harmonia do estado natural ${ }^{67}$.

A descrição lockiana dos indivíduos racionais, livres e conscientes fundamenta a base para a formação do Estado, que se voltaria para gerir as relações já existentes no estado de natureza. Este indivíduo pensante, com autonomia racional e senhor de sua vontade, "torna-se agente de sua própria história” (PEREIRA, 2006, p. 20).

O importante é ressaltar que a manifestação da liberdade e do consentimento, no contexto lockiano, é fundamentalmente uma crítica à tradição absolutista e autoritária,

\footnotetext{
${ }^{67}$ Ademais, é sempre bom lembrar que para Locke o homem, criado à imagem e semelhança de Deus, nasce livre e racional, sendo capaz de bem viver em harmonia. Todavia, o homem é reflexão e sensação, sujeito a suas experiências, logo, um ser suscetível às paixões que podem comprometer o seu lado racional. A par de se buscar a perfeita formação do homem, há que se procurar um meio de não se deixar o homem ao arbítrio de outrem, ou seja, à mercê de um juiz possivelmente parcial. Daí, então, a instituição do poder político.
} 
visando romper com a arbitrariedade. $\mathrm{O}$ ato livre do ser humano criando a sociedade política é "uma grande construção da humanidade, que cria assim o seu órgão regulador através do princípio da liberdade" (PEREIRA, 2006, p. 38).

$\mathrm{O}$ ato de liberdade, criador da sociedade política, possui conotações importantes, porque rompe com o princípio teológico do Estado e com as doutrinas absolutistas. Isso é relevante na medida em que fixa o corpo político independentemente de fatores teológicos, questão cara ao pensamento político moderno.

O poder político e a pronta submissão, nessa hipotética origem da sociedade civil, são explicáveis pelas condições da natureza humana, justificando a união dos homens: a comunidade civil sob a égide de uma lei, sob um poder político. A sociedade política é, então, um artifício, criado em dado momento, por certas razões, com peculiaridades na relação de obediência - ou pacto de submissão.

De qualquer forma, suas ponderações sobre o estado de natureza evidenciam a ideia de um direito natural (liberdade-igualdade-propriedades), anterior ao estabelecimento do poder político, sendo que é em função daquele que este gravitará. Mas, ao mesmo tempo, mostram também o sujeito de deveres, de regras, segundo a estruturação delineada pela lei de natureza. A lei de natureza prescreve, ordena e pune. Em Locke, como pondera Rolf Nelson Kuntz,

a norma natural pode ser entendida como lei no sentido forte. A lei positiva não é mais mandatória que a da natureza. É mais garantida à execução, mas nem por isso a lei natural é desprovida de eficácia" (KUNTZ, 2004, p. 96).

As consequências desse "discurso racional de moralidade", aliadas à presença divina, conscientizam o homem de seus deveres. A questão do dever passa a ser elemento vital na condução da vida social e política, pois que a lei de natureza não deixa de ser uma lei divina, e a vontade divina impõe obrigações, primeiro para com Deus, depois para com a humanidade e para com o próprio homem ${ }^{68}$. John Locke deixou bem claro isso ao descrever, no estado de natureza, que a conduta do ser humano é pautada pela preservação de si e da humanidade (LOCKE, 2005, II, 6).

Locke busca conciliar o espaço público e o privado, ao estabelecer esse compromisso natural com a autopreservação e com a preservação de toda humanidade. Aqui, estão implícitas as limitações ao direito natural, precisamente, à liberdade individual. Na articulação

\footnotetext{
${ }^{68}$ Nesse sentido, ver Edgar José Jorge Filho, Moral e História em John Locke, precisamente, "Sobre a estruturação da lei de natureza: a questão do dever para com as gerações futuras" (JORGE FILHO, 1992, p. 61$75)$.
} 
entre indivíduo e sociedade, Locke parte da premissa de que a finalidade do homem está longe de ser a vantagem pessoal, pois, segundo a lei de natureza, o seu propósito é "o interesse da república e de toda humanidade" (LOCKE, 2007, 160 - Ensaios VIII). A consequência não seria outra: predisposição para a sociabilidade ${ }^{69}$.

Talvez Locke pretendesse o estado de natureza ideal, acreditando no possível aprimoramento do homem - ser racional -, todavia, sua concepção idealista inicial cede lugar à realidade das relações humanas, com a possível inclinação ao mal, "à paixão e à vingança" (LOCKE, 2005, II, 13), que pode acarretar a confusão e a desordem.

Sim, Locke tem consciência de que, por algum "defeito da própria natureza" ou por se "furtarem à luz", nem todos seguem a razão. Logo, o fato de serem todos os homens livres e iguais, juízes e executores de suas próprias ações e da lei, obriga-o a admitir que:

[...] o amor-próprio os fará agir com parcialidade em favor de si mesmos e de seus amigos. E, por outro lado, a natureza vil, a paixão e a vingança os levarão longe demais na punição dos demais, da qual nada resultará além de confusão e desordem e, portanto, Deus certamente designou o governo para conter a parcialidade e a violência dos homens (LOCKE, 2005, II, 13).

$\mathrm{Na}$ verdade, a análise da condição natural do homem (estado de natureza e de guerra) pode nos trazer algumas indagações sobre a "psicologia" lockiana, que nos remete a um ser humano próximo a um ser cruel, tal qual o descrito na já citada passagem (LOCKE, 2005, I, 58): reduzem-se ao "extremo da brutalidade" quando abdicam da razão ${ }^{70}$. Ao que parece, uma vez que "fecham os olhos à única estrela e bússola", para evitar o estado de guerra e "o apelo aos céus" os homens se reúnem em comunidade política, abandonando o estado de natureza. Estabelecem, assim, uma autoridade, um poder terreno que dará amparo aos apelos, pois "onde existe autoridade, um poder sobre a Terra, do qual se possa obter amparo por meio de apelo, a continuação do estado de guerra se vê excluída e a controvérsia é decidida por esse poder" (LOCKE, 2005, II, 21).

\footnotetext{
${ }^{69}$ Locke é um pouco escorregadio nessa questão do dever-obrigação-direito. Até porque, o tema liberdade em si é de difícil captura. Mas o autor procura preservar a liberdade individual, sem esquecer o espaço público, tentando evidenciar o compromisso natural - dever natural dos homens. Quando analisa a "obrigatoriedade da lei de natureza", a sua assertiva de que "é dever do pai alimentar e criar os filhos, mas ninguém é forçado a ser pai" (LOCKE, 2007, p. 154), evidencia claramente que o homem é livre, mas o exercício da liberdade é limitado, pelos deveres impostos pela lei da razão.

${ }^{70}$ Locke ora parece confiar, ora temer a natureza humana. Seus escritos sempre divagam pela ambiguidade da alma humana. Mas Locke acreditava que o conhecimento de si poderia proporcionar um estado ideal: viver em obediência à lei de natureza. Eis aqui, talvez, o seu projeto "projeto político-pedagógico", na sua imbricação ética e política.
} 
Nesse sentido, vale a pena transcrever a seguinte passagem do Segundo Tratado, justificando o voluntário acerto entre os homens, para instituir a sociedade civil e a vida sob a égide da lei civil, sob um juiz imparcial:

Se o homem no estado de natureza é livre como se disse, se é senhor absoluto de sua própria pessoa e suas próprias posses, igual ao mais eminente dos homens e a ninguém submetido, por que haveria ele de se desfazer dessa liberdade? Por que haveria de renunciar a esse império e submeter-se ao domínio e ao controle de qualquer outro poder? A resposta evidente é a de que, embora tivesse tal direito no estado de natureza, o exercício do mesmo é bastante incerto e está constantemente exposto à violação por parte dos outros, pois que sendo todos reis na mesma proporção que ele, cada homem um igual seu, e por não serem eles, em sua maioria, estritos observadores da eqüidade e da justiça, o usufruto que lhe cabe da propriedade é bastante incerto e inseguro. Tais circunstâncias o fazem querer abdicar dessa condição, a qual, conquanto livre, é repleta de temores e de perigos constantes. E não é sem razão que ele procura e almeja unir-se em sociedade com outros que já se encontram reunidos ou projetam unir-se para a mútua conservação de suas vidas, liberdades e bens, aos quais atribuo o termo genérico de propriedade (LOCKE, 2005, II, 123) ${ }^{71}$.

Assim, face às características da condição natural do homem que norteiam a origem do poder político, e "se o governo há de ser o remédio aos males que necessariamente se seguem de serem os homens juízes em suas próprias causas" (LOCKE, 2005, II, 13), a questão a ser analisada agora é o processo deste consentimento à sujeição política, bem como a espécie de governo que será melhor do que o estado de natureza (LOCKE, 2005, II, $13)$.

$\mathrm{Na}$ presente linha é que são escritos os Dois Tratados $^{72}$. Locke inicia o Primeiro Tratado atacando a teoria da origem divina do poder absoluto do monarca defendida por Robert Filmer, no livro Patriarcha, or the Natural Power of Kings. Nesta obra, Filmer defende a tese de que Deus concedeu a Adão e seus herdeiros o domínio sobre a terra e sobre seus habitantes, justificando a origem divina e absoluta do poder do governante. Locke,

\footnotetext{
${ }^{71} \mathrm{~A}$ análise da teoria da propriedade em sentido estrito para Locke demandaria estudo mais acurado. Temas como "trabalho", "o valor deste", "acumulação", "fundamento liberal", entre outros, necessitam de longa discussão. O nosso propósito é apenas delinear as relações naturais (e, entre estas, está a de "propriedade privada") e os argumentos lockianos para explicar a instituição de um poder comum e o fundamento da obediência ao mesmo. Pois, como insiste Locke, o entendimento da relação de poder requer o conhecimento das relações naturais (LOCKE, 2005, II, 4).

${ }^{72}$ A partir desta preocupação é que o pacto lockiano deve ser analisado. Também é importante não perder de vista que a "evidência clara" da análise da condição natural do homem é o aspecto "teológico" da doutrina lockiana (DUNN, 1986, p. 97), pois Deus colocou o homem no estado de natureza, fixando-lhe objetivos, sendo isto tão certo quanto a ordem da criação. Capturar esta teologia natural, presente no pensamento lockiano, é a condição primeira para a compreensão do poder político. Aqui é importante lembrar que todo homem tem um só propósito: o desígnio de Deus, prescrito na lei de natureza, qual seja, a preservação da humanidade. Logo, a comunidade política não terá outra finalidade que não o bem de todos, o bem público, ou seja: preservation of all Mankind (LOCKE, 1968, II, 7).
} 
refutando esta idéia: a de que o soberano-monarca absoluto-- e representante divino possui poderes provenientes de Deus sobre os homens, combate a tese da propriedade - poder - de qualquer homem sobre outros, pois isso seria reduzir os homens a condição de escravos e,

A escravidão é uma condição humana tão vil e deplorável, tão diametralmente oposta ao temperamento generoso e à coragem de nossa nação, que é difícil conceber um inglês, muito menos um fidalgo, tomasse a sua defesa. E, na verdade, eu considero o Patriarcha do Sr. Robert Filmer, bem como qualquer outro tratado que pretendesse persuadir todos os homens de que eles são escravos, e de que assim devem sê-lo (...) não como um discurso sério e que a tal se pretenda (...) apenas posso confessar-me extremamente surpreso de que, num livro dedicado a prover de grilhões a humanidade inteira, coisa alguma se pudesse encontrar além de uma corda de areia, talvez útil àqueles cuja habilidade e ocupação consistem em levantar a poeira e que cegariam o povo para melhor iludi-lo (...) (LOCKE, 2005, I, 1).

Locke, ao refutar a tese de Filmer de que os príncipes detêm o poder político por direito divino e de que os homens não são livres para escolher seus governantes ou forma de governo (LOCKE, 2005, I, 5), busca desvincular o poder político como decorrente de Deus, afirmando-o como sendo um artifício humano, pois, no seu entendimento, os governos "são formados pelo consentimento dos homens (...), usando a razão para se unirem em sociedade" (LOCKE, 2005, I, 6).

Locke atrela o direito de ser governante e o de exigir a obediência ao pleno conhecimento (consciência) e consentimento dos integrantes da comunidade, ínsito aqui o discernimento do papel e função do governo:

(...) será vão, pois, discorrer de submissão e obediência sem que se diga a quem devemos obedecer - uma vez que, conquanto possa eu estar plenamente convencido da necessidade da magistratura e da lei no mundo, sigo, não obstante, em liberdade até que venha a luz quem é a pessoa que tem direito à minha obediência; pois senão há marcas pelas quais ela se dê a conhecer e que permitam distinguir entre os demais aquele que tem o direito de governar, este poderá ser eu mesmo, bem como qualquer outro (LOCKE, 2005, I, 81).

O poder político e o exercício deste decorrem de disposições humanas, que aquiescendo com a necessidade deste, escolhem a forma do poder governante e a pessoa que poderá deter este poder (LOCKE, 2005, I, 140). A obediência depende do arbítrio do homem, ou seja, onde a instituição humana não autoriza, ninguém pode exercer poder sobre outrem (I, 140). Assim, ao homem será facultado depositar o governo nas mãos de quem bem entender e sob a forma que mais lhe aprouver (LOCKE, 2005, I, 140).

Desta forma é que, no Segundo Tratado, Locke recorre ao estado de natureza, a liberdade natural do homem e a lei de natureza, estabelecendo que todo homem, na condição 
natural, tem um poder natural (auto-executoriedade da lei natural). Recorre a um modelo de organização já existente (pré-existente ao estado civil) e que a sociedade civil tem origem neste poder natural dos homens. Para Locke, a obediência civil, como um ato de sujeição, tem conotações legais (dever-obrigação em decorrência da lei, seja civil ou de natureza), mas, sobretudo, com substrato moral (autonomia e intenção). Por isso no Segundo Tratado expõe todo um sistema teórico sobre a origem, finalidade e limites do governo para o equilíbrio da relação de poder, na qual o ato de comandar e o de obedecer são atos conscientes do propósito, da finalidade da comunidade política, como se expõe a seguir. 


\section{CAPÍTULO II - Da Comunidade de Homens à Comunidade Política}

A proposta política lockiana apresenta a comunidade civil como um ato deliberativo da vontade de homens livres, iguais e independentes, partindo do pressuposto de que ninguém pode ser "submetidos ao poder de outrem sem o seu consentimento" (LOCKE, 2005, II, 95).

De ordinário, a comunidade política é tida como um ato de "superação" dos inconvenientes do estado de natureza. A dinâmica deste "ato deliberativo" gira em torno dos seguintes pontos: rompimento com o estado de natureza, ou seja, com a ausência de um poder comum; perda do poder natural de punir; processo peculiar de consentimento à submissão política; preocupação com possível governo arbitrário, e exercício latente da soberania e direito de punir os que "atentam" contra a finalidade da comunidade política - direito à insurreição sagrada.

A superação do estado de natureza ocorre com o abandono do poder executivo da lei de natureza. Esta renúncia representa a "constituição" da comunidade política, uma vez que se consente em instituir o poder político, instalando-se o que poderíamos denominar de “comunidade de direito" (o Estado de Direito), como se depreende da seguinte passagem:

[...] a ausência de um juiz comum dotado de autoridade coloca todos os homens em estado de natureza; a força sem direito sobre a pessoa de um homem causa o estado de guerra, havendo ou não um juiz" (LOCKE, 2005, II, 19).

Os inconvenientes da "estranhíssima doutrina" autorizaram a pensar, então, na instituição do poder político, poder este de editar leis com pena de morte e, consequentemente, todas as penalidades menores para regular e preservar a(s) propriedade(s), empregando a força da comunidade na execução de tais leis e na defesa da própria comunidade frente a dano exterior, observando "tão-somente o bem público" (LOCKE, 2005, II, 3).

A dinâmica de superação ocorre, num primeiro momento, por intermédio do que Locke denomina de "pacto" (compact), como mencionado por ele ao desenvolver seu pensamento sobre o estado de natureza. E é certo que não é qualquer pacto que faz cessar o estado de natureza entre os homens, mas somente aquele no qual concordam entre si - acordo mútuo e conjunto - "em constituir uma comunidade e formar um corpo político" (LOCKE, 2005, II, 14). 
O pacto impõe a renúncia do poder executivo transferindo-o à sociedade, ou seja, renuncia-se ao poder natural de punir e de interpretar a lei de natureza, colocando-os nas mãos do corpo político ${ }^{73}$. Haverá comunidade política com a reunião de homens em um corpo único sob "uma lei estabelecida comum e uma judicatura à qual apelar, com autoridade para decidir sobre as controvérsias entre eles e punir os infratores". O início da comunidade política equivale ao "fim do direito/poder" dos homens livres e iguais de executarem a lei de natureza (LOCKE, 2005, II, 87).

Locke insere a "política" na dimensão da vida coletiva, como uma forma de relação social "aprimorada" no contexto de elo de confiança existente entre os homens. Os homens livres e iguais substituíram a "estranha doutrina" pelo corpo legislativo. Eis o começo das sociedades políticas (LOCKE, 2005, II, 99).

A esta união e concordância, Locke atribui caráter histórico. Com efeito, na medida em que analisa as possíveis objeções a seu entendimento da "concordância em unir-se em um corpo político" (pacto), expõe a "historicidade" de seu pensamento, como se observa nas seguintes passagens:

Revela uma estranha inclinação a negar a evidência dos fatos, quando não concordam com sua hipótese, aquele que não admite que o início de Roma ou de Veneza deu-se mediante a união de vários homens livres e independentes uns dos outros, entre os quais não havia nenhuma superioridade ou sujeições naturais [...] (LOCKE, 2005, II, 102).

E espero que se admita que todos aqueles que saíram de Esparta com Palento, mencionados por Justino (L. 3, c. 4), eram homens livres, independentes uns dos outros, e estabeleceram um governo sobre si por seu próprio consentimento. Portanto, apresentei diversos exemplos tirados da História de pessoas livres e no estado de natureza, as quais, tendo-se juntado, incorporaram-se e deram início a uma sociedade política [...] (LOCKE, 2005, II, 103).

Os exemplos acima, “insistência no conteúdo empírico da idéia de contrato", evidencia a diferença entre o estado de natureza e o civil e a ideia da transferência de poder pelo consentimento. A alusão ao grupo que deixou Esparta estabelecendo "livremente um governo tem, sobretudo, um valor didático: deixa clara a distinção entre o político e o não político e ressalta a imagem da independência entre os indivíduos” (KUNTZ, 2004, p. 108).

\footnotetext{
${ }^{73}$ A seguinte passagem Segundo do Tratado é explicativa: "A única maneira pela qual uma pessoa qualquer pode abdicar de sua liberdade natural e revestir-se dos elos da sociedade civil é concordando com outros homens em juntar-se, em unir-se em uma comunidade, para viverem confortável, segura e pacificamente uns com outros, num gozo seguro de suas propriedades e com maior segurança contra aqueles que dela não fazem parte". (LOCKE, 2005, II, 95).
} 
O pacto político, independentemente de seu caráter histórico ou não, traz ínsita a preocupação com o consentimento, com o mútuo acordo à submissão política e o elo de confiança entre os participantes. Isso já faz surgir duas importantes indagações: Quem participa do pacto e quais as condições para esta participação? Qual o conteúdo (cláusulas) e finalidade deste pacto?

Locke não enfrenta diretamente tais questões ${ }^{74}$. Inclusive, antes mesmo de enfrentar e caracterizar o "pacto político" propriamente dito e de definir a sociedade política, analisa algumas formas de relações entre os homens ("pactos" - como relações familiares e de “trabalho"), procurando diferenciá-las do "pacto político". O seu propósito era evidenciar, ou melhor, negar que as mesmas possam ter qualquer semelhança com um "pacto político" ou possam fornecer a "gênese" do poder político, para daí extrair suas conclusões sobre a comunidade e autoridade políticas:

a primeira sociedade foi entre o homem e sua mulher, que deu início à que há entre pais e filhos; à qual, com o tempo, veio a juntar-se a que há entre senhor e servidor. E embora todas estas sociedades pudessem juntar-se, e em geral o tenham feito para formar uma única família, cujo senhor ou senhora tinha uma espécie qualquer de governo apropriado a uma família, cada uma delas, ou todas, estavam ainda longe de constituir uma sociedade política, tal como veremos se considerarmos os diferentes fins, vínculos e limites de cada uma delas (LOCKE, 2005, II, 77).

A sua preocupação é muito clara: opor-se às teorias que tentam explicar a comunidade política como uma evolução natural, independentemente da vontade do homem, bem como afastar-se das teorias tradicionalistas do poder político monárquico e das concepções que defendiam a desigualdade natural entre os homens. Daqui, talvez também se possam extrair algumas considerações sobre os integrantes e sobre as condições do pacto de sociedade política.

Não se descuida que a sua metodologia, num primeiro momento, não se apresente didática, mas talvez o faça dessa forma por ter afirmado que não é "qualquer pacto" que inicia a comunidade política, buscando demonstrar pela negação o que entende como a origem do poder político. O certo é que Locke inicia sua explanação analisando os tipos de "sociedades"

\footnotetext{
${ }^{74}$ Para Locke, o estado de natureza é um estado de intensas relações-interações: relações de amizade, familiares, de trabalho, de troca e de "propriedade". A base é o liame da confiança entre os homens voltados à mútua preservação, ou seja, relações sociáveis de convivência envoltas por um determinado fim, qual seja, o "propósito de Deus": preservar-se e a toda a Humanidade. De outra forma, seria inócuo o mandamento: "crescei e multiplicai-vos", seria em vão a determinação: "amarás o teu próximo como a ti mesmo". A igualdade e a liberdade coexistem sopesadas pelo respeito mútuo, pautadas pela lei de natureza. Da comunidade natural dos homens, estas relações serão "transpassadas" para a comunidade política, sob a égide da lei positiva e de um poder comum.
} 
entre os homens e o próprio poder "paterno", para somente depois destas observações concluir pela natureza do pacto e do poder político, precisamente, esclarecer a finalidade da comunidade civil $^{75}$. Seguiremos este mesmo raciocínio.

\subsection{Das Associações dos Homens}

\subsubsection{As Associações "Naturais"}

O capítulo VII do Segundo Tratado mostra características interessantes da sociabilidade lockiana:

Tendo Deus feito o homem uma criatura tal qual que, segundo seu próprio juízo, não lhe era conveniente estar só, colocou-o sob fortes obrigações de necessidade, conveniência e inclinação para conduzi-lo para a sociedade, assim como o proveu de entendimento e linguagem para perpetuá-la e dela desfrutar (LOCKE, 2005, II, 77).

Argumentos acima declinados, como obrigação, necessidade e conveniência, poderiam transmitir, num primeiro momento, a ideia de uma sociabilidade "forçada". Mas as expressões "inclinação para a sociedade" e "proveu de entendimento e linguagem", aliadas à "determinação da lei de natureza: preservar a si e a humanidade", mostram a sociabilidade imanente no perfil do homem lockiano.

O espírito da própria lei de natureza já denunciava que a sua observância significa a vida em comum com relações de amizade e harmonia, base de toda comunidade. O homem

\footnotetext{
${ }^{75}$ De ordinário, tem-se que Locke escreveu os Dois Tratados sobre o Governo Civil para refutar as teses absolutistas do poder contidas na obra $O$ Patriarca, de Robert Filmer, publicada em 1680, na qual este defende tese sobre o poder absoluto do monarca, fundada numa concepção paternalista na relação entre soberano e súdito. O Primeiro Tratado é uma minuciosa réplica ao primeiro livro do Patriarca, contra a desigualdade natural dos homens desenvolvida por Filmer, para quem "Deus estabeleceu a desigualdade entre os homens, colocando uns acima dos outros, os pais acima dos filhos, os homens acima das mulheres, os mais velhos acima dos mais novos e os monarcas acima de todos [...]" e, após afirmar a liberdade e a igualdade natural do ser humano, "Locke vai desenvolver sua teoria sobre o governo no Segundo Tratado sobre o Governo - um Ensaio Referente à Verdadeira Origem, Extensão e Objetivo do Governo Civil" (NASCIMENTO, 2001, p. 1339-1340). Muito se pergunta por que Locke teria escolhido Filmer e não Thomas Hobbes para a discussão em torno da origem do poder. Hobbes publicou o Leviatã em 1651, antes dos Tratados, e, embora Locke combata as teses dos "realistas" sobre o poder absoluto do monarca das quais Filmer era partidário, muito do que desenvolve no Segundo Tratado contrasta com a tese jusnaturalista e contratualista de Hobbes. Segundo a explicação de Norberto Bobbio, "Filmer era um adversário a combater, Hobbes o adversário a discutir, com o qual, mesmo em plena controvérsia, é preciso concordar de vez em quando" (BOBBIO, 1997, p. 164).
} 
lockiano é um homem integrado à humanidade, deixando longe a ideia de que somente depois deste "pacto" é que os homens tornaram-se sociáveis ${ }^{76}$.

Locke nos concede uma visão extremamente propensa à sociabilidade, divagando sobre as várias formas de associação dos seres humanos - tipos de relações que podem travar, independentemente de se estar no interior de uma comunidade natural ou política.

No capítulo VII do Segundo Tratado, sua análise sobre a "sociedade civil ou política", como salientado, inicia-se com observações de "associações" (pactos) entre os seres humanos, procurando diferenciá-las da comunidade política.

A primeira "associação" que Locke nos aponta é a do homem e da mulher, originando a família. A sociedade conjugal é formada por pacto voluntário, entre o homem e a mulher (LOCKE, 2005, II, 78), trazendo consigo o dever de apoio e assistência mútuos, como também “uma comunhão de interesses, necessária não só para unir seus cuidados e afeto, mas também para sua progênie comum, que tem o direito de ser alimentada e sustentada por eles, até que seja capaz de prover às próprias necessidades" (Ibid., 77).

Locke observa que a união entre o homem e a mulher não se destina meramente à procriação, devendo ser mais duradoura do que a união de outras espécies, pois visa à perpetuação do próprio ser humano - da Humanidade. Está implícito aqui o mandamento da lei de natureza: preservar a si e à humanidade, bem como o mandamento divino: "crescei e multiplicai-vos".

O autor analisa também, de forma detalhada, o pátrio poder, asseverando que este tem origem no dever imposto aos pais de "cuidar de sua prole durante o imperfeito estado de infância. Formar a mente e governar as ações dos menores ainda ignorantes, até que a razão ocupe seu lugar e os liberte desse incômodo - é disso que os filhos precisam" e isso os pais estão obrigados a proporcionar (LOCKE, 2005, II, 58). Afinal, os pais são seres livres e os filhos, na medida em que passam a ter "entendimento próprio para governarem suas vontades", alcançarão a condição de seres livres.

Segundo Locke, a "condição de liberdade" é dada nos limites da lei à qual se está submetido, "seja natural ou civil". Logo, o que torna o homem livre é o grau de maturidade

\footnotetext{
${ }^{76}$ Detalhe interessante a ser repensado com cuidado é o caráter utilitário/instrumental do pacto instituidor da sociedade civil, para diminuir aquela noção de que "Locke imagina o Estado como uma sociedade de seguros: reunimo-nos para conseguir que nossos direitos estejam mais e não menos protegidos" (GRANDONA, 2000, p. 25). Este é o ponto mais delicado quanto à natureza do pacto. Talvez porque ainda não tenhamos um entendimento correto da "era de ouro" lockiana e tendemos a achar que a sociabilidade a que ele se refere é aquela em que se poderia ter-viver independentemente da "lei positiva", logo, da sociedade política.
} 
em que seja "capaz de conhecer a lei, para que possa manter suas ações nos limites dela" (LOCKE, 2005, II, 59). A submissão aos pais é algo necessário até que se atinja a maturidade suficiente para alcançar esse conhecimento e a sua liberdade natural (Ibid., 61).

A preocupação lockiana, nesse ponto, é clara: este capítulo é uma crítica às teses paternalistas do poder e dos "cegos defensores da monarquia por direito de paternidade". ${ }^{77} \mathrm{O}$ fato é que o "dever de cuidado" não se transforma em "domínio absoluto e arbitrário dos pais". Locke enfatiza bem as características do ser humano: livre e racional, deixando evidente a sua preocupação com a base da sua proposta política.

As eventuais "relações de subordinação" entre cônjuge, pais e filhos e "serviçais" domésticos não devem ser confundidas com uma "pequena sociedade política". O "chefe de família" possui "um poder muito diferente e diversamente limitado, tanto em relação ao tempo como à extensão sobre as várias pessoas que dela fazem parte [...], ele não tem nenhum poder legislativo de vida e morte sobre nenhum dos membros da família, e nenhum a mais do que a senhora da família poderia ter em igualdade com ele" (LOCKE, 2005, II, 86) ${ }^{78}$.

Na tentativa de ser mais elucidativo e demonstrar a relação de confiança, de certa liberdade e do compromisso em cumprir acordos, Locke declara que:

o poder do marido está tão longe do de um monarca absoluto que a esposa tem, em muitos casos, liberdade para separar-se dele, se o direito natural ou o contrato entre eles o permitir, seja este contrato celebrado no estado de natureza, seja segundo os costumes e as leis do país em que vivem; e, no evento de tal separação, os filhos ficarão com o pai ou com a mãe, conforme determine o contrato (LOCKE, 2005, II, 82).

Locke evidencia a preocupação com a relação moral, descreve regras e responsabilidade no interior da organização familiar, coerente com o seu entendimento de que o ser livre é o racional, capaz de governar a sua vontade (LOCKE, 2005, II, 63).

Para Locke a existência humana, seja no estado natural ou político, é uma existência caracterizada pela sociabilidade, por relações afetivas, e a família - sociedade conjugal e de pais e filhos - tem presente a relação de afeto. Aqui é interessante lembrar os argumentos

\footnotetext{
${ }^{77}$ Locke procura dissociar sua "sociedade" familiar da visão aristotélica da família como célula primeira da sociedade civil. Também objetiva distanciá-la da teoria patriarcal do poder político. Eis o foco da sua explanação.

${ }^{78}$ O capítulo em que Locke aborda o 'Pátrio Poder' é realmente 'rico' na análise das relações no grupo familiar e de seus membros como parte 'integrante' da comunidade dos homens (natural ou civil). Locke analisa vários aspectos e regras, desde contendas simples entre os cônjuges, gênese do poder político (que mostra a 'necessidade' de um poder comum para a análise dos eventuais problemas), até questões relacionadas à 'propriedade' e direito de herança, entre outras. Deixa sempre evidente a importância das relações morais e o fim do homem, criatura de Deus, na estrutura das relações sociais como um todo.
} 
lockianos sobre a "liberdade-responsabilidade", analisada quando das reflexões sobre a lei de natureza: o homem é livre para ter ou não ter filhos, segundo sua vontade e liberdade. Logo, uma vez feita a "livre opção" de constituir uma prole, surge a responsabilidade/dever do cuidado e da assistência.

A sociabilidade, ou seja, o fato de que "Deus não criou o homem para viver só", deve ser entendida no espaço de liberdade e racionalidade que the foi reservado: liberdade de escolha e do seu consentimento.

A organização familiar - sociedade - volta-se para a mútua assistência, bem como para a proteção e assistência da prole ${ }^{79}$. Assim, os cônjuges se atribuem reciprocamente direitos e obrigações, por meio de um contrato voluntário. Locke evidencia que a sociedade conjugal tem fundamento contratual, nada tendo de natural. É uma sociedade voluntária com o objetivo de procriação e criação dos filhos (LOCKE, 2005, II, 78).

É importante ressaltar a possibilidade de dissolução desta associação, "tão logo seus objetivos sejam alcançados", mas, enquanto persistir, há que se respeitar seus limites e nenhum pode ter mais direito que o outro. Em suma:

[...] nenhum dos dois dispõe sobre o outro de uma autoridade de caráter político, o contrato que os une não é um contrato político e a sociedade que os reúne não constitui, portanto, um corpo político. Mas a existência de um contrato basta, no entanto, para mostrar que as necessidades naturais que induzem a espécie humana à vida conjugal não podem ser satisfeitas, mesmo no estado natural mais primitivo, senão em virtude de decisões racionais de um livre poder de vontade. Não pode, portanto, existir indivíduo absoluto e independente, mas somente indivíduos associados em sociedade, ao menos temporárias, de indivíduos não fisicamente, mas essencialmente sociais (POLIN, 2003, p. 165-166).

Locke, ao lado da "sociedade familiar", menciona o "contrato" entre "senhor e servo". Explica que a expressão "senhor e servidor" é tão antiga "quanto a própria História, mas aplicados a pessoas de condições bem diferentes" (LOCKE, 2005, II, 85), fazendo a seguinte diferenciação:

- Situações em que homens livres tornam-se servidores de outros, vendendo por certo tempo seu serviço em troca de remuneração. Embora tal relação possa fazer com

\footnotetext{
${ }^{79}$ Locke tem grande preocupação com a análise do poder - poder sobre outrem - tanto que procura fundamentar o poder dos pais sobre o filho intimamente ligado ao direito que estes têm à vida (alimento, segurança e educação), o que corresponderia mais a um dever dos pais que o geraram, do que propriamente poder. Pelo que, "falando do poder de ordenar que têm os genitores, durante a menoridade, diferente do direito ao respeito que surge mais tarde, Locke tem o cuidado de precisar, no Capítulo VI do Segundo tratado, dedicado exclusivamente ao "poder paterno", que "para falar com propriedade, o primeiro deles é mais um privilégio dos filhos e um dever dos pais do que uma prerrogativa do poder paterno"”' (BOBBIO, 1997: 212).
} 
que o "servo" se estabeleça na casa de seu "senhor", ficando obrigado a seguir a disciplina da "casa", isso não concederá ao senhor mais poder do que o estabelecido no contrato entre ambos. E esse poder é temporário (LOCKE, 2005, II, 85).

- Situações de "servos" na condição de escravos, prisioneiros capturados em guerra justa e que, por direito de natureza, sujeitam-se ao domínio absoluto e arbitrário de seu senhor. Nesta linha, Locke explica que os "escravos", por terem perdido o direito à vida, a liberdade e suas propriedades, não são considerados "integrantes de uma sociedade". Logo, esta situação não é capaz de formar um "contrato", pois este implica estabelecer direitos e obrigações, e o escravo, por sua própria condição, fica “à margem deste tipo de relação" (LOCKE, 2005, II, 85).

Locke descreve estas duas relações, nas quais há a figura do "senhor" (master), admitindo somente na citada primeira hipótese (servo e senhor) a possibilidade de se estabelecer uma sociedade - contrato -. No seu entendimento, a relação contratual envolve uma relação de direitos e obrigações e o elemento vontade, exigindo a condição de sujeito livre para a formalização do contrato, para se estabelecer trocas. In casu, a venda do tempo e do serviço em troca de remuneração. Isso somente é possível na relação entre servo e senhor.

A relação entre senhor e escravo deu-se em virtude da "força", embora "justa", estando fora das relações entre seres com capacidade para decidir, capazes de obrigações. Como observa Polin, o "domínio do déspota sobre o escravo, que não nasceu de um contrato, não pode ser pretexto de nenhum contrato" (POLIN, 2003, p. 167).

$\mathrm{Na}$ família, Locke distingue a relação entre marido e mulher e entre pais e filhos, analisa os distintos direitos e poderes inerentes a estas sociedades, e enfatiza que tais relações diferem das existentes em uma sociedade política. Em suas palavras:

De que maneira, porém, uma família, ou qualquer outra sociedade de homens, difere do que é propriamente chamado sociedade política se perceberá melhor ao considerarmos em que consiste a própria sociedade política (LOCKE, 2005, II, 86) ${ }^{80}$.

\footnotetext{
${ }^{80}$ Sobre a análise lockiana referente à relação familiar, Maria Cecília Pedreira de Almeida observa que embora tenha se colocado contra a tese patriarcalista de Filmer e a versão aristotélica da origem da sociedade, "tal como em Filmer", para Locke, "a família é a célula social originária, é a comunidade natural e o primeiro degrau que conduz à formação da cidade, concepção herdada de Aristóteles. Nela o pai exerce uma autoridade de tipo monárquica (...)", concluindo que Locke "acaba" concordando que o pai tem uma autoridade natural e que "a sujeição da mulher para com o seu marido também tem uma fundação na natureza", assim, citando Franck Lessay, afirma que "Locke se liga mais a Filmer do que ele gostaria" (LESSAY apud ALMEIDA, 2006, p. 95).
} 


\subsubsection{A Comunidade Política}

Segundo Locke "sempre que qualquer número de homens estiver unido numa sociedade de modo que cada um renuncie ao poder executivo da lei da natureza e o coloque nas mãos do público, então, haverá uma sociedade política ou civil” (LOCKE, 2005, II, 89).

A renúncia de um implica necessariamente na renúncia de todos, na concordância mútua em "deixar parcialmente" de ser livre e independente. A privação da parcela da liberdade natural do homem ocorre com o seu consentimento, como observa Grandona:

o que funda a passagem da sociedade natural à sociedade política é que "ninguém pode ter poder sobre mim a não ser que eu o tenha dado previamente". A base do poder é o consentimento dos futuros governados (GRANDONA, 2000, p. 24).

O certo abandono da liberdade natural é o marco inicial pelo qual todas "as sociedade políticas tiveram início", através da "união voluntária e no mútuo acordo de homens que agiam livremente na escolha de seus governantes e formas de governo" (LOCKE, 2005, II, 102).

O iter de seu raciocínio, nos "exemplos didáticos" do estado de natureza anteriormente citados, evidencia a concepção lockiana das características da vida coletiva e das relações de afetividade.

Por um lado, é certo que os exemplos trazidos por Locke da "infância" das sociedades exaltam a aquiescência com o "governo", ou melhor, com uma certa "organização de comando", com base na relação de confiança mútua, elemento crucial no seu pensamento político. De outro, há que se ponderar que a "renúncia ao poder executivo" da lei de natureza não seria, por si só, o fator determinante da comunidade política "inicial".

Embora Locke faça questão de enfatizar o "pacto" com base no consentimento, segundo ele, as primeiras "sociedades" não seriam fundadas em contrato explícito. É provável que a presença de um "juiz" e a "renúncia ao poder natural de punir" não sejam as diferenças substanciais entre o estado de natureza e o estado civil. Pelo menos no que toca ao início das comunidades políticas.

Os exemplos lockianos, exarados no seu Segundo Tratado sobre o Governo Civil, permitem assinalar que as primeiras sociedades voltavam-se para a defesa externa, e este seria o fator principal a determinar a escolha do governo e a forma desta "sociedade": 
Portanto, uma vez que é impossível deixar de presumir que aqueles que estimavam tanto uns aos outros a ponto de se reunirem em sociedade tivessem uma familiaridade e amizade entre si, bem como alguma confiança mútua, somente poderiam eles temer mais aos inimigos externos do que um ao outro. Por conseguinte, não se pode supor que seu cuidado e pensamento primordiais fosse outro senão o de guardar-se das forças estrangeiras (LOCKE, 2005, II, 107).

De forma provável, este teria sido inicialmente o fator determinante a impulsionar a instituição do corpo político, da forma de governo e dos fins deste. A simplicidade de vida, com "posses" voltadas para a subsistência, não geraria "grandes conflitos" entre os homens. Logo, a preocupação primeira seria com possíveis inimigos externos.

Nas primeiras organizações políticas, voltadas mais para a defesa externa, Locke permite-se refletir sobre "uma possível diferenciação" natural entre os homens, ao conceder que poderia ser natural que se procurasse o "homem mais sábio e mais corajoso" para ser o governante. Tais qualidades seriam essenciais para definir a liderança e condução na eventualidade de uma guerra frente a inimigos externos.

Talvez, Locke pretendesse apenas demonstrar que a escolha e a função de chefe ou de comando estariam ligadas à defesa externa, porque, inicialmente, a vida coletiva interna poderia ser considerada mais branda, buscando comprovar seu pensamento no exemplo histórico da América:

Vemos assim que os reis dos índios da América, que é ainda um modelo do que foram os primeiros tempos da Ásia e da Europa, quando os habitantes eram demasiado escassos para o país e a falta de pessoas e de dinheiro não dava aos homens tentação alguma de aumentar suas posses de terra nem de competir por maiores extensões de solo, são pouco mais que generais de seus exércitos; e, embora comandem de modo absoluto na guerra, quando estão em seu território e em tempo de paz exercem um domínio muito reduzido e têm uma soberania muito moderada, ficando as resoluções de paz e de guerra nas mãos ou do povo ou de um conselho. Embora a própria guerra, que não admite uma pluralidade de dirigentes, devolva naturalmente o comando à autoridade única do rei (LOCKE, 2005, II, 108).

Aqui, Locke evidencia a evolução dos povos, os "estágios" que qualquer sociedade política teve que trilhar no seu processo evolutivo. Locke, como observa Rolf kuntz, percebeu que "os grupos da América poderiam oferecer o interesse especial de mostrar, ao vivo, estágios há muito superados pelas civilizações da Europa e da Ásia. No século seguinte, essa noção de etapas seria lugar comum no pensamento social” (KUNTZ, 2004, p. 109). 
A infância da comunidade política não apresenta um reclamo maior pela figura do juiz imparcial e da lei positiva ${ }^{81}$. Nesta "idade de ouro", a maioria dos homens livres e racionais direcionavam-se pela "bússola" da razão. As primeiras comunidades políticas, fundadas em contratos implícitos, caracterizavam-se por "uniões" voltadas mais para a defesa externa, do que propriamente para "contendas internas". Além disso, não seriam numerosas e provavelmente, com exploração de subsistência, como Locke deixa entrever no capítulo V, no qual analisa a "origem da propriedade". Logo, sem grandes contendas relativas a bens materiais.

Nestas comunidades iniciais, a chefia era concedida a uma determinada pessoa governante único --, uma vez que voltavam, prioritariamente, para a defesa externa. A guerra - estratégias de guerra - não admite pluralidade de comandos, e esta relação é transposta para a organização da comunidade, como uma continuidade do elo de confiança e segurança que este tipo de chefia apresentava.

Assim, Locke concede que a "confiança, a inocência e a sinceridade", presentes na infância da sociedade política, certamente fizeram com que os primeiros iniciadores da comunidade política conferissem o poder de mando a um único homem, independentemente de qualquer "outra limitação ou restrição expressas a não ser as que a natureza da coisa e os fins do governo exigiam" (LOCKE, 2005, II, 110). Locke quer demonstrar aqui que houve um grande depósito de confiança para os fins esperados: bem e segurança do público. Caso não fosse assim, nenhuma sociedade política teria subsistido, pois "sem pais zelosos que cuidassem com ternura e atenção do bem público, todos os governos teriam sucumbidos sob a fraqueza e as enfermidades de sua infância; e logo príncipe e povo teriam perecidos juntos" (Ibid.).

\footnotetext{
${ }^{81}$ O comunismo originário de Locke, ao analisar a propriedade (LOCKE, 2005, II, 26 e 27), nos dá conta deste particular. Inclusive, todo o Capítulo V: "Da propriedade" deixa entrever uma certa evolução (não sistematizada, é claro) na forma de produção: coleta - pastoreio - agricultura - até a acumulação de capitais. Denota estágios pelos quais as comunidades teriam passado no seu processo evolutivo econômico-social, mostrando a interferência das relações econômicas e sociais na organização política, e as implicações destas no processo evolutivo das comunidades políticas. Cada fase ou forma de organização apresenta problemas característicos. Desta forma, a função jurisdicional, segundo Rolf Kuntz, apresenta "pouca importância nas primeiras etapas, quando a população é pequena, a propriedade privada ainda não se desenvolveu, a ambição é moderada e as ocasiões de conflitos internos são raras" (KUNTZ, 2004, p. 109).Isso, aliado ao conteúdo do § 111, explicitando esta possível evolução, trará também sérias implicações ao perfil psicológico do ser individual e coletivo lockiano. No seu paradigma de homem ideal, Locke tenta reduzir ao máximo a rivalidade e a ambição hobbesiana na construção de seu limite moral e político, partindo do homem natural. Coerente com a sua formação cristã ou acreditando que o conhecimento de si aproxima o homem do controle si, Locke tenta estigmatizar o ser primitivo interior.
} 
Locke admite que os primeiros governos poderiam recair numa única pessoa e inclusive coincidir com a figura do pai (LOCKE, 2005, II, 107). Tratava-se, é certo, de sociedade não muito numerosa, sem muita complexidade, cuja exploração econômica voltava-se para a própria subsistência e cuja preocupação central era a defesa externa. Neste contexto, é compreensível que o elo de confiança na figura do pai fosse transferido para a organização política. Ives Michaud observa que esta é a única concessão que Locke faz a Filmer, ou seja:

(...) no começo, efetivamente, os reis foram muitas vezes pais que geriam sua comunidade como uma família e as prerrogativas de um soberano prudente e sábio faziam as vezes de leis ainda inúteis (II, 162). Todavia, mesmo se se começa pelo patriarca e pela monarquia, os direitos e deveres do soberano-pai de família já não são mais familiares e o consentimento dos súditos-filhos é de natureza política (II, 105). Por outro lado, a monarquia original é adaptada a sociedades militares que devem defender-se sob a unidade de comando de um general. Em comparação, o governo civil é adequado a sociedades desenvolvidas em que a complexidade das relações sociais e riqueza acarretam uma complexidade do direito, no qual o soberano deve velar pelo bem de um corpo político complexo (MICHAUD, 1991, p. 44).

Ainda assim, a ideia de "consentimento" e de "relação de confiança" estão presentes, pois as pessoas livres, por seu próprio consentimento, se submetem ao governo do pai ou se unem com diferentes famílias para formar um governo. O poder de mando, neste raciocínio, seria depositado nas mãos de um único homem, com a submissão à condução política de uma única pessoa, "sem uma condição expressa a limitar ou regular seu poder, que consideravam estar bastante assegurado pela honestidade e prudência de tal pessoa" (LOCKE, 2005, II, 112). O governo inicial, seja o familiar, seja o monárquico, traz ínsito o liame afetivo e a relação de confiança mútua.

A pouca complexidade das primeiras comunidades ditava a forma do governo, ou seja, "a monarquia original é adaptada a sociedades militares que devem defender-se sob a unidade de comando original". Na medida em que as relações se diversificam e a sociedade se torna mais desenvolvida, o governo civil se torna mais adequado, pois "a complexidade das relações sociais e riqueza acarretam uma complexidade do direito, no qual o soberano deve velar pelo bem de um corpo político complexo" (MICHAUD, 1991, p. 44).

A igualdade entre os homens, nas comunidades políticas iniciais, face "à vida simples limitada aos confins da pequena propriedade”, sem grandes controvérsias explica a ausência de um reclamo por leis e juiz para as raras contendas. 
$\mathrm{Na}$ medida em que as relações se tornam mais complexas, as interações sociais vão se diversificando, alterando as relações entre os homens, com possíveis conflitos, tornando necessário um juiz comum. A centralização do poder punitivo e a figura do juiz, de fato, acarretam uma substancial alteração nas relações da comunidade. Mas, como observa Kuntz:

essa alteração não corresponde à imposição de uma forma a um conjunto de
agentes atomizados. Para Locke, a independência natural consiste
simplesmente na relação igual entre os indivíduos, sem subordinação
regular. Essa independência não deve ser entendida como isolamento e
muito menos como guerra de todos contra todos. A criação do governo
corresponde a uma exigência criada pela vida coletiva, num determinado
nível de complexidade. Pode ser difícil, em certas passagens, determinar
uma fronteira entre os dois estágios, o natural e o político. (KUNTZ, 2004,
p. 111).

Não é tarefa fácil, no desenrolar do pensamento lockiano, determinar com certeza onde termina o estado de natureza e se inicia o político. A descrição da infância da comunidade política assemelha-se ao estado de natureza. A complexidade das relações e o aparecimento das contendas ficam próximos ao estado de guerra. Os limites são tênues. Mas, em função dos próprios exemplos da "América", pode-se concluir que as tribos indígenas são modelos de comunidade política infantil. Possuem um "chefe", possuem limites, regras e valores, entre outros aparatos inerentes às organizações políticas. Os “índios da América”, exemplo de como era o mundo, possuem um pacto implícito entre si e o elo afetivo é um traço marcante na organização destas tribos americanas, destacando-se a confiança e o respeito mútuo a guiar a conduta de seus integrantes.

$\mathrm{Na}$ evolução da infância das sociedades, além da relação entre os próprios homens, Locke nos aponta outra questão interessante no vínculo entre comando e comandados. No início, nenhum embate pode ter ocorrido entre governantes e governados relativamente à condução do governo. Todavia, observa que:

quando a ambição e o fausto de idade ulteriores quiseram reter e aumentar o poder sem desempenhar as funções pelas quais este lhes havia sido concedido e, ajudados pela adulação, ensinaram os príncipes a ter interesses distintos e separados dos de seus povos, os homens julgaram necessário examinar com mais cuidado as origens e os direitos do governo, e encontrar maneiras de restringir os excessos e de evitar os abusos desse poder que haviam confiado às mãos de outrem apenas para o próprio bem deles e que viam estar sendo usados para prejudicá-los (LOCKE, 2005, II, 111).

A presente passagem mostra a preocupação com a condução do governo e a maneira de exercê-lo, como também com o fato de que nem todos se encaminham pela égide da razão, evidenciando a necessidade de regras escritas, impondo limites a governados e principalmente 
ao governante. Com efeito, o uso da expressão "encontrar maneiras de restringir excessos" evidencia a preocupação em se definir, expressamente, a finalidade e os limites do governo, estabelecendo regras para o uso do poder. Afinal, governo e governados são homens livres e iguais, e embora a base desta relação seja o consentimento e a confiança mútua, sabe-se que nem sempre todos se guiam pela razão.

Ora, o homem não deixou sua liberdade natural para se submeter ao domínio e arbítrio de outrem, por isso é necessário estabelecer regras ao exercício do governo. Se não fosse assim, melhor seria o estado de natureza, "no qual os homens não são obrigados a se submeterem à vontade injusta" de outro homem (LOCKE, 2005, II, 13) ${ }^{82}$. O estado de natureza, ainda que com seus inconvenientes, seria melhor que um governo despótico.

No Capítulo IX do seu Segundo Tratado, Locke tece considerações sobre "os fins da sociedade política e do governo", fixando parâmetros para a exigência da "obediência civil", evidenciando a sua preocupação com a "instalação" de possível poder despótico. Antes, porém, de analisarmos tais diretrizes, abriremos um parênteses para algumas considerações a mais sobre o próprio pacto instituidor da comunidade política, para melhor entender o trust lockiano, e a sua proposta político participativa.

\footnotetext{
${ }^{82} \mathrm{Na}$ medida em que se optou por uma organização política, confiando-se o poder para um determinado fim: bem do povo (LOCKE, 2005, II, 3), Locke se preocupou com eventuais situações, nas quais este poder possa estar sendo usado para prejudicá-lo (LOCKE, 2005, II, 111), ficando clara a quebra de confiança por parte daquele a quem se confiou o governo. No estado social deposita-se um voto de confiança de que a inicial harmonia do estado natural poderá ser resgatada. Surge, então, com essa preocupação, a necessidade de estabelecer regras relativas à finalidade e aos direitos do governo, a fim de que se possa ter mecanismos para evitar eventuais abusos, estabelecendo limites às ações daqueles a quem foi confiando o poder político.
} 


\subsection{Comunidade Política e Governo}

\subsubsection{Pacto de Associação e Pacto de Submissão}

Locke inicia a sua análise sobre "os fins da sociedade política e do governo", no Capítulo IX do seu Ensaio sobre a verdadeira origem, limites e finalidade do governo civil, com a seguinte indagação:

Se o homem no estado de natureza é livre como se disse, se é senhor absoluto de sua própria pessoa e suas próprias posses, igual ao mais eminente dos homens e a ninguém submetido, por que haveria ele de se desfazer dessa liberdade? Por que haveria de renunciar a esse império e submeter-se ao domínio e ao controle de qualquer outro poder? (LOCKE, 2005, II, 123).

Locke articula suas ideias com base na seguinte premissa: o homem livre e independente, voluntariamente, decide restringir a sua liberdade natural e, concordando com a instituição de uma sociedade política, passa a viver sob a égide de um direito positivo, sob um poder único.

A indagação acima nos remete a duas outras questões, ou problemas distintos, como observa Quentin Skinner (2009, p. 436):

1) num primeiro momento, a motivação direta da renúncia: saber a razão pela qual se deixa a liberdade natural, concordando em se sujeitar ao poder de outrem.

2) num segundo momento, emerge a questão da formalização desta renúncia e instituição da comunidade política, precisamente o ato legitimador: o pacto ou contrato social.

A motivação direta da renúncia à liberdade natural é evidenciada pela análise da condição natural do homem ${ }^{83}$. Não obstante fosse senhor destes direitos - liberdade, posses e sua própria pessoa -, o exercício dos mesmos, no estado de natureza, é bastante precário, incerto e exposto a violação, pois todos são também senhores absolutos e, sendo "todos reis

\footnotetext{
${ }^{83}$ Locke concede que nem sempre basta recorrer "à lei da razão para a solução dos conflitos. O Estado de natureza possui vários inconvenientes, tais como a ausência de uma lei estabelecida e reconhecida por todos como tal e o fato de cada homem se apresentar como o próprio intérprete da lei de natureza não se sustenta por si mesmo, tornando necessário o aparecimento de um poder comum, enfim, de um governo que possa fazer as funções do juiz, onde a lei seja clara para todos e quem a executa também receba autoridade da sociedade para o exercício da sua função, que deve primar pela imparcialidade" (NASCIMENTO, 2001, p. 1339-1340).
} 
na mesma proporção" - cada homem um igual - e não sendo "em sua maioria, estritos observadores da equidade e da justiça, o usufruto que lhe cabe da propriedade é bastante incerto e inseguro" (LOCKE, 2005, I, 123). A conservação de si e da própria humanidade, como visto, impulsionou o pacto instituidor da comunidade política ${ }^{84}$.

A análise da natureza do pacto lockiano pressupõe a compreensão da finalidade da comunidade política e da sua concepção de poder político. Logo de início, Locke frisa que o poder civil (político) consiste na prerrogativa de fazer leis, cominando as respectivas penas, "e de empregar a 'força da comunidade' na execução de tais leis” (LOCKE, 2005, II, 3).

A existência do "poder político" exige a renúncia à liberdade natural de interpretar e executar a lei de natureza. Isto se processa por intermédio de um "pacto", no qual há "delegação" do poder de editar leis, pelo consentimento de homens livres. A concordância mútua em formar a comunidade - único pacto que faz cessar o estado de natureza -- é a única maneira aceitável, já que os homens são todos livres e iguais.

A celebração do pacto consentido e o consequente ingresso na comunidade política implicam na renúncia, por parte de todos os homens livres, ao direito de autodefesa e ao direito de castigar os crimes cometidos contra a lei de natureza, ou seja, ao direito de executar a lei de natureza (LOCKE, 2005, II, 128).

Há no pacto uma cessão parcial dos direitos inerentes à condição natural do homem ${ }^{85}$. O cidadão cede a sua capacidade de definir e interpretar a lei natural sem que o governo possa alterá-la, pois os mandamentos da lei de natureza permanecem intactos. Mas cede totalmente

\footnotetext{
${ }^{84}$ Ao abordar o início e a motivação da sociedade política, Locke enfatiza que o ser humano "projetou unir-se para mútua conservação" de interesses supremos da pessoa, que são a vida, a liberdade e outros bens, conjugando bens materiais e imateriais como inerentes aos seres livres e iguais. Pode-se afirmar que, aqui, Locke coloca uma pá de cal nas intensas discussões de que a sociedade civil visa exclusivamente à proteção propriedade enquanto bem material em sentido estrito.

${ }^{85}$ Na questão do pacto e consentimento, é muito interessante a conjugação da "motivação direta da renúncia da condição natural" e a própria condição legitimadora do corpo político: "o consentimento". Com efeito, o processo do 'consentimento' implica na percepção do homem como individualidade (o que requer conhecimento em sentido amplo e autoconhecimento), bem como, percepção da própria 'coletividade' em reconhecer-se como um "corpo único" que pode mover-se em determinada direção, executando atos coletivos visando determinado fim. No Segundo Tratado, Locke não teceu considerações sobre o homem como ser moral, como pessoa, se reconhecendo (e percebendo) como uma identidade única. Todavia, bem delineou as características do homem natural: ser livre e racional. Na verdade, para Locke os homens nascem livres, iguais e racionais. Todos possuem as mesmas capacidades, todos são "sensação e reflexão" e quando guiados pela "estrela e bússola razão", conseguem captar a lei de natureza que os leva a um único fim: preservação mútua. Logo, o "conjunto de homens" é formado por homens livres, iguais e racionais, guiados pela lei de natureza. Não estão "soltos" no mundo, não formam um "bando" ou seres meramente agregados, ao contrário, a condição natural do homem apresenta fortes características morais, vivendo sob uma ordem específica: a lei de natureza. O "ser lockiano" é um ser dotado de faculdades, com capacidade de autodeterminação. Dessa forma, são homens capazes de consentirem, mutuamente, (consentimento comum) em se reunirem em um corpo político firmando um sério compromisso entre si, voltados para um objetivo comum: preservação mútua.
} 
o poder de castigar a violação de seus direitos, ou seja, "o homem se desarma e já não pode mais castigar. O Estado tem que interpretar a lei mediante um juiz frente a cada conflito e executar sua sentença” (GRANDONA, 2000, p. 26).

A lei civil a ser editada, baseada na lei de natureza, volta-se à preservação do homem, de suas possessões e à defesa da sociedade, observado o interesse público. Este é o principal limite do poder político (LOCKE, 2005, II, 3). A renúncia é condicional, pois confia poderes a outrem visando determinado fim. Logo, a comunidade política e o governo são instrumentos para a proteção do homem, da comunidade e do interesse público.

De acordo com Locke, uma vez que os homens são naturalmente livres, nada poderia colocá-los “em sujeição a qualquer poder terreno a não ser o seu próprio consentimento". Resta saber, então,

o que entenderemos por uma declaração suficiente do consentimento de um homem, para sujeitá-lo às leis de qualquer governo. Existe uma distinção corrente entre consentimento expresso e tácito [...] (LOCKE, 2005, II, 119).

Locke menciona a necessidade de uma "declaração suficiente do consentimento" e acrescenta que esta declaração pode ocorrer por intermédio de um consentimento "expresso" ou "tácito". O consentimento expresso consiste no ingresso de qualquer homem em uma sociedade, tornando-o membro perfeito dessa mesma sociedade (LOCKE, 2005, II, 119) ${ }^{86}$. Para Locke, este tipo de consentimento não pode ser "renunciado". Todo aquele que, por um "acordo de fato e declaração expressa, deu o seu consentimento em fazer parte de alguma sociedade política está perpétua e indispensavelmente obrigado a ser e permanecer inalteravelmente súdito desta [...]”. (LOCKE, 2005, II, 121).

A anuência declarada em instituir o estado civil acarreta a impossibilidade de retomar a sua liberdade natural, de voltar ao estado de natureza. Pelo pacto, o homem renuncia à liberdade natural, adquirindo a liberdade civil. A não ser que, por uma fatalidade qualquer, o "governo sob o qual vivia venha a ser dissolvido", ou então "que algum decreto público impeça-o de continuar" sendo membro desta comunidade política (LOCKE, 2005, II, 121).

\footnotetext{
${ }^{86} \mathrm{O}$ "consentimento", como ato legitimador do "organismo político", não é algo novo apresentado por Locke. Já era uma ideia generalizada entre os escolásticos. Segundo Quentin Skinner, os seguidores de Occam, assim como Tomás de Aquino, já enfatizavam a ideia de que o "organismo político legítimo" tem origem num ato de consentimento. Todavia, assevera que "não há dúvida de que essa concepção foi estudada com novo alento graças aos tomistas do século XVI, em particular Suarez, cuja análise do tema no Tratado das leis e de Deus legislador pode ser considerada como tendo fornecido as diretrizes para a abordagem do mesmo tópico por alguns dos principais autores constitucionalistas do século XVII. O primeiro aspecto especialmente ressaltado por Suarez é que o ato de consentir constitui o único meio pelo qual pode ser criada uma república legítima" (SKINNER, 1996, p. 439-440).
} 
A seu turno, o consentimento tácito decorre das situações em que o homem, por ter alguma posse ou por usufruir de qualquer parte dos domínios de um governo, "dá, com isso, o seu consentimento tácito e está tão obrigado à obediência às leis desse governo, durante esse usufruto, quanto qualquer outro que viva sob o mesmo governo" (LOCKE, 2005, II, 119).

O consentimento tácito impõe a sujeição ao governo, independentemente da declaração da vontade da pessoa, bastando apenas que se tenha alguma posse, "quer consista tal posse em terras, para si e seus herdeiros para sempre, ou num alojamento por apenas uma semana; ou mesmo que esteja apenas viajando livremente por uma estrada" (LOCKE, 2005, II, 119). Sendo assim, o consentimento alcança uma pessoa a despeito de sua real vontade, sendo suficiente o fato de "estar alguém nos territórios de um governo" para ser considerado como tendo consentido à instituição do estado civil, e estar obrigado a se submeter às regras da "comunidade política".

Além disso, Locke procura evidenciar que o mesmo ato pelo qual uma pessoa, antes livre, se liga a uma sociedade política necessariamente une suas posses ao comando desta sociedade. Ambas, pessoa e posses ficam "sujeitas ao governo e ao domínio dessa sociedade, enquanto ela existir" (LOCKE, 2005, II, 120).

Instala-se aqui uma verdadeira obrigação em função da "coisa possuída". Seja por herança, compra, permissão ou qualquer outra via pela qual uma pessoa usufrua de qualquer parte da terra, anexada a uma comunidade política e "sob o seu governo, deve recebê-la com as condições às quais está sendo submetida; isto é, submetê-la ao governo da sociedade sob cuja jurisdição ela se encontra, tanto quanto qualquer súdito desta" (LOCKE, 2005, II, 120).

A jurisdição do governo está adstrita ao seu território - suas terras -, alcançando o proprietário "apenas enquanto nela more e dela usufrua algo". Assim, a obrigação de se submeter ao governo "começa e termina com o usufruto da posse". E, vale dizer, no caso do consentimento tácito, o dono poderá, por doação, venda ou qualquer outro meio, abandoná-la, tendo a liberdade de "ir incorporar-se a qualquer outra sociedade ou concordar com outros em iniciar uma nova" em qualquer território livre e desocupado (LOCKE, 2005, II, 121).

No que se refere à condição dos estrangeiros, Locke anota que, embora devam se submeter às leis do governo, usufruindo dos privilégios e da proteção deste, "não passam por isso a ser súditos ou membros dessa sociedade política". O seu argumento é o de que "nada pode fazer com que um homem o seja, a não ser sua efetiva entrada nela, por um compromisso positivo, e promessa e pacto expressos" (LOCKE, 2005, II, 122). 
Locke conclui suas considerações sobre o pacto, no Capítulo VIII do Segundo Tratado, afirmando que é isso o "que pensa" a respeito "do início das sociedades políticas e do consentimento que faz de qualquer um, membro de um corpo político" (LOCKE, 2005, II, 122). Mas isso não é tudo. Há mais considerações sobre o pacto espalhadas pelo seu escrito, que Locke deixou de enfrentar diretamente.

De fato, há questões relevantes na formalização do pacto, cujo entendimento pode ser considerado importante para a compreensão da própria finalidade do "corpo político":

- O pacto lockiano contemplaria um só pacto, como em Hobbes, ou teríamos dois pactos distintos, na esteira de Samuel Pufendorf?

- Quem, efetivamente, participa do(s) pacto(s)?

Sabe-se que muitos dos filósofos jusnaturalistas dos séculos XVII e XVIII, como Pufendorf (século XVII), entendiam que o contrato pelo qual se dá inicio à sociedade política desdobra-se em dois, a saber:

- um pacto entre os homens livres e iguais, no qual há a manifestação de suas vontades em se unir formando uma sociedade - pacto de associação;

- um pacto, que se segue ao anterior, entre o "povo" e o governo - pacto de "sujeição civil” -, no qual se designa a quem será confiado o governo da comunidade política.

Os pactos acima mencionados "representam" dois momentos na formação da comunidade política: um criando o corpo social e o outro o governo. Observa-se que Locke, de fato, não faz referência direta à existência de dois pactos. Chega-se a tal conclusão, pela leitura do capítulo XIX, no qual aborda a dissolução do governo. Neste ponto, os estudiosos do tema apontam uma "falha" na doutrina lockiana, pois Locke

não se mostrava absolutamente claro sobre o que surgia exatamente do "convênio originário". Se seria a própria sociedade ou o governo? Que ambas são diferentes ele categoricamente afirmou [...] quando argumentou que a revolução política que dissolvia o governo não dissolvia, geralmente, a comunidade que o governo dirigia (SABINE, 1964, p. 525).

George H. Sabine, neste sentido, afirma que Locke assumia tacitamente uma posição semelhante à de Pufendorf, reconhecendo dois contratos, "embora em nenhuma parte a declarasse". Referenda sua tese com o argumento de que, para Locke, o estabelecimento do governo era algo de importância menor do que o "convênio originário que informava a sociedade civil", pois "todo o poder da comunidade residia naturalmente nela", e o poder 
"atribuído" ao governo era apenas um poder fiduciário. Assim, o "povo conservava o poder supremo de alterar o legislativo quando ele desmerecesse a confiança que lhe fora depositada" (SABINE, 1964, p. 527).

Na mesma trilha segue o entendimento de David Held, citado por Vladimir Jorge, segundo o qual:

os indivíduos não fazem um, mas dois pactos. [...] o primeiro é estabelecido para criar uma sociedade independente; o segundo, uma sociedade política ou governo. [...] a distinção é importante porque deixa claro que são os indivíduos da sociedade que outorgam a autoridade ao governo, com o intuito de perseguir os fins dos governados. Se esses fins não forem representados adequadamente, [...] o poder de magistrado, ou seja, o direito de fazer cumprir as leis de natureza retornará ao povo (HELD apud JORGE, 2009, p. 102).

De acordo com Norberto Bobbio, embora em nenhum momento de sua obra Locke tenha falado "explicitamente desse segundo pacto, ao qual se referiu Pufendorf - uma de suas fontes habituais", o seu silêncio não significa que não reconhecesse "a distinção dos dois momentos: o da formação do corpo social e o da formação do governo propriamente político. Encontramos no último capítulo [...] o reconhecimento explícito de tal distinção entre dissolução da sociedade e dissolução do governo" (BOBBIO, 1997, p. 226) ${ }^{87}$.

Segundo Sérgio Morresi, embora haja um só pacto na conformação da sociedade política, é preciso reconhecer que este possui duas etapas distintas: a) a primeira é a que "nos leva da multidão de indivíduos a uma Comunidade que é um corpo único que atua com uma só vontade, da maioria" (II, 96), e b) a segunda é a que ocorre quando o poder "da Comunidade é confiado a representantes para que o exerçam em seu nome" (MORRESI, 2005, p. 2005-2006). O autor complementa que alguns "estudiosos (ARENDT, 1999) viram no argumento dos "dois momentos" a confirmação da idéia de que para Locke haveria "dois pactos”, um social e outro político". No seu entender, isso é um engano, e, citando Yolton, explica que "embora Locke distingue sociedade de governo, não pretende que a primeira possa existir sem o segundo, pois "em toda Comunidade deve existir algum poder supremo

\footnotetext{
${ }^{87}$ Saulo Henrique S. Silva, ao abordar o tema, discorre que, paralelamente ao pacto que inicia a sociedade civil, há a atribuição de confiança (trust) a um governo, e "este segundo momento consiste na primeira lei positiva da sociedade: criação do poder legislativo [...]. Sobre o assunto, concordamos com Laslett e Macpherson que Locke separa o processo de pacto, que institui uma comunidade particular - "original compact" --, baseado no consentimento expresso das pessoas [...], do processo seguinte pelo qual a maioria da commonwealth confia o poder político a um governo, os representantes da população que possuem um encargo fiduciário ('fiduciary trust')" (SILVA, 2008, p. 48).
} 
sem o qual não pode haver verdadeiramente Estado""' (LOCKE apud YOLTON, 1996, p. 53) (MORRESI, 2005, p. 205-206) ${ }^{88}$.

No entendimento de Philippe Raynaud, a teoria lockiana "apresenta uma originalidade entre as concepções do século XVII", pois não se confunde com a de Hobbes, que identifica o contrato social e a formação do poder soberano, nem com a de Pufendorf, que faz distinção entre um pacto de associação e um pacto de submissão: "o vínculo entre o povo e os poderes públicos não é um contrato mas um trust, isto é, uma missão de confiança ou um cargo que o povo confia àqueles que o representam" (RAYNAUD, 1993, p. 679). O autor argumenta que, ao se considerar a existência de um vínculo contratual entre o povo e o soberano, seria sugerir que, "por um lado, o povo aliena sua soberania e, de outro, que os titulares do poder público tiram vantagens do contrato pelo qual eles se comprometem; essas duas teses seriam inaceitáveis para Locke" (RAYNAUD, 1993, p. 679) ${ }^{89}$.

Locke, além de não ter se referido de forma clara aos dois tipos de contrato, também não utilizou a palavra "contrato" expressamente ao se referir ao acordo político. No Capítulo VIII: "Do início das sociedades políticas", Locke utiliza as expressões "consentimento", "maioria", "comunidade", "corpo político" e "pacto original” (v.g., LOCKE, 2005, II, 93, 97, 98 e 99) ${ }^{90}$. Depois, utiliza "poder da comunidade", "depositário do poder supremo" (v.g., LOCKE, 2005, II, 132) e, ao final, evidencia a relação de confiança (trust) no exercício de poder, ao refletir sobre a finalidade do governo e o direito de resistência (LOCKE, 2005, II, 240).

\footnotetext{
${ }^{88}$ Sobre o tema, Morresi argumenta que os homens, ao cederem seus poderes naturais e formarem uma comunidade, não tinham como objetivo "autogovernar-se como comunidade". O objetivo era confiar esses poderes recebidos "a um Governo Civil que se transforma, por esse ato de confiança (trust), em seu "representante"", havendo "na conformação da Sociedade Política", dois momentos, "mas um só pacto, (...) deste modo, podemos afirmar, como na versão straussiana, que "sociedade política e governo só podem separarse na mente, mas não têm uma existência independente: a sociedade política precisa do governo" (GOLDWIN, 1996, p. 475, ênfase acrescentada). Assim, para Locke, como para Hobbes, a situação política supõe algum tipo de instância representacional" e conclui que "estes representantes", para Locke, "são os encarregados de positivar a Lei de Natureza (...)” (MORRESI, 2005: 206).

${ }^{89}$ Raynaud sustenta sua tese citando o parágrafo 93 do Primeiro Tratado: "Se bem que as partes possam estar ligadas entre si por uma relação contratual, os membros do povo não têm obrigação contratual para com o governo, e os governantes se beneficiam do governo somente como membros do "corpo político"'. Citando, ainda o parágrafo 240 do Segundo Tratado e Peter Laslett, afirma que "são apenas deputados do povo, encarregados de missão, que podem ser mandados embora se falharem em suas missões", concluindo que os Dois Tratados, a partir deste fato, podem conter "uma das grandes teorias do regime representativo: o povo não está subordinado aos governantes, ele é a instância suprema para estimar a ação destes governantes [...]" (RAYNAUD, 1993, p. 679-680).

${ }^{90}$ No Primeiro Tratado, ao refutar "a monarquia hereditária de Adão" e discorrer sobre a transmissão do poder, utiliza a expressão "contrato": "o poder fundamentado num contrato somente pode ser transmitido àqueles que tenham direito pelo mesmo contrato" (LOCKE, 2005, I, 96).
} 
Nosso autor refere-se aos governantes como meros deputados (trustees), depositários de confiança do povo, podendo ser "demitidos" quando falharem na responsabilidade incumbida. Isso enfatiza a relação de confiança entre governante e governado, deixando claro que o "poder é confiado às mãos de outrem" (LOCKE, 2005, II, 111), implicando em “poder condicional”, concedido em confiança - poder fiduciário - (LOCKE, 2005, II, 149) ou “encargo fiduciário" (LOCKE, 2005, II, 156).

Na verdade, a palavra "contrato" é pouco utilizada e "raramente aplicada a questões políticas"91. Para Peter Lasllet, "vago como é, Locke parece aqui estar tentando, deliberadamente, evitar ser específico e deixar de lado os modelos legais. Isso pode implicar que a transmutação para a condição política e social não deve ser encarada de forma legal: é uma forma variável e também um tanto solta nesse contexto" (LASLLET, 2003, p. 269).

A partir deste raciocínio, Peter Laslett (2003, p. 270) argumenta que Locke não almejava "descrever um instrumento formal de confiança para o governo", ou seja, sua intenção era realçar que a relação entre governo e governados não é uma relação contratual, uma vez que o "trust" não é um contrato ${ }^{92}$. A lógica lockiana seria evitar que governo e governados "ficassem contratualmente relacionados entre si". O contrato implica partes envolvidas que retirem algo dele, o que, "aplicado à política, significa que o governo obtém do ato de governar algo que os governados são obrigados a ceder. Locke queria evitar este tipo de relação/obrigação.

A seu ver, o povo estava contratualmente relacionado entre si, mas não estava "contratualmente obrigado" em relação ao governo. Com isso, os governantes se beneficiariam "do ato de governar apenas como membros do "corpo político"”, pois seriam meros deputados em nome do povo, ou seja, “'trustees' (depositários da confiança) que podem ser demitidos se falharem em sua responsabilidade (ao 'trust') (II, § 240)". (LASLETT, 2003, p. 270).

\footnotetext{
${ }^{91}$ Como observa Laslett, voltam-se a arranjos legais ou semilegais, como casamento (I, 47, 98; II, 81-2) ou arranjos de propriedade (II, 194) (LASLETT, 2003, p. 269).

92 Segundo Laslett, na medida em que Locke utiliza a palavra "trust" para os vários poderes políticos, afasta a possibilidade de que haja uma relação contratual entre governo e governados. Locke "divide o processo de pacto, que cria a comunidade (community), do processo ulterior pelo qual a comunidade confia o poder político a um governo". Enfatiza que, embora os "atos" possam ser simultâneos, eles são distintos. Distingue, assim, o "contrato de sociedade" do "contrato de governo", muito embora este último não seja "de modo algum um contrato". Locke pretendia apenas destacar e evidenciar que as "ações do governo são limitadas à finalidade do governo, que é o bem dos governados, e demonstrar, por contraste, que aí não existe nenhum contrato - somente relação fiduciária” (LASLETT, 2003, p. 271).
} 
São várias as interpretações sobre o "pacto lockiano" quanto à constituição da comunidade política e à instituição do governo. E, de fato, a relação entre governante e governados é algo peculiar no pensamento lockiano, decorrência da sua construção de moralidade inscrita nos Ensaios, que proporciona uma relação estável de confiança e de harmonia aos que se guiam pela razão. É possível aceitar que Locke não tenha se referido a dois pactos, visando, realmente, ressaltar o caráter fiduciário do segundo. Todavia, sob o enfoque de estruturação, a relação específica entre governante e governados não deixa de ser um "pacto", pois o depósito de confiança implica partes e implica na delegação de algo, implica em assumir obrigações e direitos.

A relação de "fidúcia", segundo Locke, é algo condicional - condicionado por e a determinado fim. O poder confiado ao governante é tido como condicional, pois o poder natural permanece nas mãos do povo, que poderá retomá-lo. Locke buscava enaltecer mais a "relação de crédito", já legitimando o seu pensamento da "insurreição sagrada", do que propriamente a noção de um simples "contrato" com o governante ${ }^{93}$.

A opção lockiana em não utilizar a expressão "contrato" pode realmente estar ligada a sua recusa em aceitar um pacto ou contrato em termos hobbesianos. Embora Locke não tenha se referido a Hobbes e tampouco refutado diretamente sua "teoria do poder soberano do Estado", tem-se como certo que esta sua escolha pode ter sido uma forma de evitar eventual direcionamento à ideia de "submissão contratual ao poder supremo estatal" 94.

Ora, um contrato, na medida em que é bilateral, implica partes e a possibilidade de ser rescindido (ínsita à cláusula "rebus sic stantibus"). Todavia, pode ser que para evitar alusão ao

\footnotetext{
${ }^{93}$ Yolton, no seu Dicionário Locke, não faz alusão à existência de dois pactos ao analisar as expressões pacto ou contrato (compact ou contract). Menciona que Locke "identifica dois fatores em que a sociedade humana parece estar alicerçada, isto é, primeiro, uma constituição definitiva do Estado e forma do governo; e, segundo, o cumprimento de pactos [...]. A palavra "pacto" tende a ser usada mais frequentemente do que "contratos", mas há passagens em que ambos os termos ocorrem". O autor observa ainda que "é a formação da sociedade política ou civil que usualmente acode à mente quando é mencionado o termo "contrato". Os homens fazem várias promessas e pactos no estado de natureza, assim como dentro da sociedade civil. Um pacto pelo qual concordam, "mutuamente e em conjunto, em formar uma comunidade e fundar um corpo político", transfere-os do estado de natureza para a sociedade civil $(\mathrm{T} 2,14)$. Tal pacto é descrito como o pacto "original" [...]" (YOLTON, 1996, p. 181-182).

${ }^{94}$ É forçoso conceder que Locke não foi muito claro nesta questão, porém, da análise de alguns parágrafos do Segundo Tratado - 95 a 97, 121, 211 e 232, entre outros -, há que se permitir uma conclusão pela existência de dois pactos, ou pelos menos dois momentos (ou duas relações distintas) na formalização da "comunidade política". Percebe-se um primeiro momento, no qual todos os homens livres e iguais, voltam-se à formação da comunidade, com a renúncia de todos ao poder executivo da lei natural; e outro, entre os "associados" e o eventual governo, no qual se estabelece a base do poder deste e a esperada submissão nos limites em que se pactuou. Aqui fica claro que esse poder "delegado" é um poder fiduciário - sob confiança -, precisamente, condicionado a determinado fim. O povo conserva o poder de alterar o legislativo ou destituir o governo caso afastem-se das finalidades em razão das quais foram formalizados (LOCKE, 2005, II, 232).
} 
contrato social ou ao pacto do Leviatã que torna o soberano titular dos direitos e poderes de todos, Locke tenha sido "vago" nesta parte.

A sua reflexão sobre a relação de "trust", na qual fundamenta a "sujeição" política, visa afastar a ideia de que a "tradição", como pretendia Robert Filmer, ou o "medo" possam fundamentar o poder político. O pacto original não é um pacto de submissão a um governo (por medo ou tradição), a legitimidade do poder político advém do livre consentimento e o sustentáculo do governo está na relação de confiança ${ }^{95}$.

A decisão de formar uma comunidade - uma unidade - um só corpo político, em suma, comporta dois momentos distintos ou pactos: 1) a constituição da comunidade (civil), objetivando a instituição do poder comum, pela união consentida de um certo número de homens que renunciam ao poder natural de interpretar a lei natural e de executá-la, e 2) depósito de confiança a terceiro(s) deste poder - escolha dos representantes, do governo -que deverão usar o poder nos termos preestabelecidos: “bem comum” (LOCKE, 2005, II, 3).

As pessoas livres, iguais e racionais renunciam ao direito de usar o poder natural de que dispõem para a proteção de suas vidas, liberdades e bens contra ataques dos outros (LOCKE, 2005, II, 129), consentindo em obedecer ao governo da "Commonwealth" (LOCKE, 2005, II, 133). Todavia, não renunciam ao direito à vida e à liberdade. Estes continuam a pertencer integralmente à pessoa humana, "não porque seria absurdo que fosse de outro modo, mas porque o direito de dela dispor escapa ao próprio indivíduo. Ninguém pode transferir mais poder do que tenha e ninguém tem sobre sua vida e sobre sua liberdade um poder arbitrário" (POLIN, 2003, p. 179) ${ }^{96}$.

\footnotetext{
${ }^{95}$ Locke, no seu Primeiro Tratado, refuta expressamente a obra de Sir Robert Filmer: O poder natural dos Reis, na qual Filmer defende o absolutismo e o direito divino do poder político, afirmando que "nenhum homem nasce livre e a base de todo governo é uma monarquia absoluta". Nos Dois Tratados, Locke, em momento algum, faz menção a Hobbes. Mas o desenrolar de seu texto, como as características do estado de natureza e a natureza do poder político, evidenciam que confrontava as ideias hobbesianas. Thomas Hobbes, de acordo com os argumentos apresentados na sua obra de grande impacto, salienta que cada indivíduo, através do "contrato ou pacto social", renuncia em favor do soberano a seus poderes e direitos, sendo que essa renúncia não mais poderia ser "revista", ou seja, não há volta ou direito de arrependimento, não se pode mais, depois do "contrato", postular a retirada do poder concedido ao "soberano". É certo que Hobbes refere-se a um só contrato de "associação e submissão". Como visto, a proposta lockiana é frontalmente inversa, o que talvez tenha feito com que não tenha utilizado a palavra "contrato". Mas são nítidos os dois estágios - momentos - ou pactos na conformação dos homens na "commonwealth", ou não seria possível a "insurreição", dissolução do governo sem a dissolução da sociedade.

${ }^{96} \mathrm{E}$, são estes argumentos que sustentam a sua teoria de resistência, nos casos de quebra de confiança por parte do governo, como se verá à frente, evidenciando a preocupação com o eventual abuso de prerrogativas e privilégios a evitar "embates entre governo e governados" (LOCKE, 2005, II, 111).
} 
Ainda sobre o pacto e consentimento, questão a ser analisada é a de quem participa do pacto - consente - na criação da comunidade política, na visão lockiana. Nesta questão, Locke, ressaltando a importância do consentimento, argumenta que:

por conseguinte, o que inicia e de fato constitui qualquer sociedade política não passa do consentimento de qualquer número de homens livres capazes de uma maioria no sentido de se unirem e se incorporarem a uma tal sociedade (LOCKE, 2005, II, 99).

Pois, sendo do interesse do povo, bem como sua intenção, contar com uma representação equânime e justa, quem quer que mais o aproxime disso é um indubitável amigo e estabelecedor do governo, e não pode deixar de obter o consentimento e a aprovação da comunidade (LOCKE, 2005, II, 158).

As citadas passagens levantam indagações nada fáceis de serem resolvidas. Quem são os homens livres no pensamento lockiano? O alcance das expressões "capazes de uma maioria" e "representação equânime para o bem do povo" podem aproximar Locke do "mito da participação popular efetiva”?

A doutrina lockiana apresenta algumas dificuldades nesse ponto, valendo a pena transcrever mais algumas passagens, para se concluir sobre a noção de "todos":

[...] Deus não deixou um único homem à mercê de outrem de modo que este pudesse fazê-lo morrer de fome se assim o desejasse [...] homem algum jamais poderia dispor de um justo poder sobre a vida de outrem por direito de propriedade sobre a terra ou outros bens, dado que sempre seria um pecado, para qualquer homem de posses, deixar perecer seu irmão ao não se valer de sua abundância para aliviar a condição dele (LOCKE, 2005, I, 42).

Em primeiro lugar, ele deve governar através de leis promulgadas e estabelecidas [...]. Em segundo lugar, tais leis não devem destinar-se a outro fim que não, em última análise, o bem do povo (LOCKE, 2005, II, 142).

A interpretação das passagens acima permite concluir por um Locke de maioria igualitária - do povo na acepção correta do termo -, ou seja, todos os seres livres e racionais escolhem e decidem sobre o seu destino, sobre o bem do povo, sobre o bem público, ditando as bases da comunidade e do governo. Realmente mostrando um Locke próximo a um pensamento político igualitário.

Ocorre que as reflexões lockianas sobre a condição dos escravos (LOCKE, 2005, II, 62-64) invalidam, de certa forma, a possibilidade de visão igualitária em sua doutrina. Locke teria excluído os escravos da noção de todos e de maioria, pois não são livres. Os escravos estão fora da noção de homens livres (freemen). 
Também os que não se guiam pela "bússola da razão" encontram-se excluídos da condição de homens livres ${ }^{97}$. Os "irracionais não dominam" suas paixões e desejos - não possuem vontade própria, e por não terem domínio sobre si, não são livres para Locke. Logo, tanto os escravos como os "irracionais" não são proprietários de sua própria pessoa, condição esta imprescindível para bem direcionar sua conduta, seu agir, seja no aspecto individual ou coletivo.

A aquiescência com a escravidão pode retirar a possível visão igualitária e "popular" lockiana. Por outro lado, a despeito dos fatores históricos da época - do panorama socioeconômico da Inglaterra do século XVII -, tem-se dúvida de que os homens livres e racionais lockianos sejam apenas os proprietários e os arrendatários, na acepção de proprietários de bens materiais.

Primeiro, porque a expressão "propriedade" para Locke é ampla, engloba a vida, liberdade e possessões. Sobretudo, a propriedade de si. Segundo, porque, no parágrafo 42 do Primeiro Tratado, Locke é claro ao afirmar que nenhum homem "por direito de propriedade sobre a terra ou outros bens" teria direito sobre outrem. Logo, a posse, por si só, não traria privilégios ou poderes políticos. Não se pode, de pronto, imputar-lhe a condição de pensador político elitista ${ }^{98}$.

Macpherson afirma que para Locke somente os proprietários de bens e fortuna compõem a noção de povo, pois seriam os únicos homens livres e racionais lockianos. Seus argumentos se voltam à crítica da noção de propriedade em Locke, que "repetidas vezes" menciona que "a grande finalidade da união dos seres em sociedade civil, e para se colocarem, sob o governo, é a preservação de suas propriedades”. Locke, a seu ver, é ambíguo ao se referir à propriedade como "vidas, liberdades e posses", porque,

Quando a propriedade é assim definida, todos têm motivo para ingressar na sociedade civil, e cada um está capacitado para nela ingressar, tendo alguns direitos que possam transferir. Mas, Locke não se apegou a essa definição. Ele usou o termo em dois sentidos diferentes, nos trechos em que seu significado era decisivo para sua argumentação. A propriedade para a proteção da qual os homens se comprometem com a sociedade civil é algumas vezes declarada vida, liberdade e posses, e outras vezes claramente, bens e fortuna. O resultado disso é que os homens sem fortuna ou bens, ou

\footnotetext{
${ }^{97}$ Aqui temos os que "por defeito da natureza" não chegam ao grau de razão adequado (LOCKE, 2005, II, 60), os filhos sob o poder dos pais até a maturidade e os que perderam a razão, deixando de seguir esta "bússola".

${ }^{98}$ A presença da escravidão e a condição dos serviçais na obra lockiana perturbam. Na verdade, contrasta com sua "formação cristã", que nos levaria à igualdade de todos no plano formal e material. E, a questão fica mais difícil ainda ante as interpretações extremadas do alcance da expressão "todos" na sua teoria política. Mas, devemos ler Locke no tempo de Locke e assim, certas contradições podem ser atenuadas.
} 
seja, sem propriedades, no sentido comum, estão legitimamente dentro da sociedade civil, e ao mesmo tempo, não estão. (MACPHERSON, 1979, p. 259).

Os trechos a que Macpherson faz alusão são os parágrafos 138-140 do Segundo Tratado. Tais trechos estão inseridos no Capítulo XI: "Da extensão do poder legislativo". Aqui, especificamente, Locke mostra não só a relevância da lei, mas os limites ao próprio poder de legislar, "que não poderá exceder ao poder que tinham as 'pessoas' (que 'substituem') quando estavam no estado de natureza". É claro que entre as propriedades do homem estão as suas posses materiais, de ordinário, adquiridas pelo "labor honesto", sendo natural que isso seja levado em conta na "proteção" exigida da sociedade política.

Na sua leitura Macpherson reduz a representação - participação política - somente aos proprietários. Para ele, "somente os que têm fortuna podem ter cidadania, por duas razões: apenas esses têm pleno interesse na preservação da propriedade, e apenas estes são integralmente capazes de vida racional [...] a classe operária, não tendo fortuna, está submetida à sociedade civil, mas dela não faz parte" (MACPHERSON, 1979, p. 260).

A conclusão decorre da referência ao citado parágrafo 140: "poder de impor e coletar tributos junto ao povo". E, Macpherson pretende assim deixar claro que somente os que possuem fortuna e posses materiais preocupam-se com a tributação. Também alude à questão do consentimento tácito - simples fato de ter propriedade - para se considerar incorporado a uma sociedade.

Ora, as implicações relativas ao consentimento tácito se inserem no contexto normal do poder de polícia da commonwealth, necessário para a administração da "coisa pública". Já a questão: "nenhum imposto sem representação" (LOCKE, 2005, II, 140), historicamente, não é uma questão especificamente dos ricos e afortunados. O conceito de "povo" ou de "todos", como sendo somente aqueles que "pagam imposto" ou têm posse material, seria uma tentativa de redução não condizente com o todo ou, melhor, com o conjunto de ideias exposto no citado Capítulo XI, sobre as limitações do poder de legislar ${ }^{99}$.

Francisco Reis, ao refletir sobre a ideia do "contrato" como "arma de luta da burguesia", conclui que para Locke todos participariam do "pacto", com exceção dos escravos, que não são homens livres. Para ele, não tem fundamento a separação entre

\footnotetext{
${ }^{99} \mathrm{O}$ "poder natural" é delegado à sociedade - corpo político - que autoriza o legislativo "a elaborar leis segundo exija o bem público" (LOCKE, 2005, II, 89). Ademais, segundo M. Hughes (apud MORRESI, 2005, p. 210), a Inglaterra de fins do século XVII era uma "nação de pagantes de impostos (a tax-payer nation)".
} 
proprietário e não proprietário, porque o conceito de propriedade em Locke é amplo. A única vez que Locke se refere de forma restrita, no sentido de posse material, é no capítulo específico sobre a propriedade. Isto é relevante, “mas não é à forma restrita de compreensão do conceito de propriedade que Locke se refere ao tratar dos fins do Estado. Nesse caso, ele sempre o toma na maneira abrangente" (REIS, 1988, p. 114).

Não se tem de pronto uma lógica para concluir que somente os proprietários "de posse material" seriam a "maioria", o "povo" ou "todos os homens livres", na concepção lockiana, para o consentimento na "criação" da sociedade. Francisco Reis observa ainda que o contrato político é firmado entre homens livres e iguais e "isolados", porque não há como se falar em "classes" no estado de natureza. Ainda que Locke veja os homens no estado de natureza como sociais, argumenta que:

ele não deriva desta sociabilidade qualquer repercussão quanto à associatividade parcial dos homens de qualquer espécie. Assim, no estado de natureza lockeano não há associações de qualquer espécie. Ora, na medida em que não há associações, grupos ou classes no estado de natureza, é na condição de indivíduos isolados que os homens estabelecem contratos (REIS, 1988, p. 115).

Os homens na condição natural descrita por Locke poderiam ou não ter posses materiais, mas todos, com exceção dos escravos, possuíam direito à vida e à liberdade, possuíam a propriedade de sua própria pessoa. Logo, como seres livres e racionais, na busca de se preservar e preservar a humanidade (mandamento da lei de natureza), estão aptos a participar do pacto, a consentir mutuamente em iniciar uma comunidade política.

Assim, o consentimento da maioria, entre qualquer número de homens, forma a comunidade - o corpo político. O consentimento da maioria é tido como o consentimento de todos. Aqui, Locke deixa claro que a "unanimidade" não é o elemento essencial, pois o sustentáculo é a "regra da maioria".

A leitura de James Tully (1982, p. 154) encaminha-se no sentido de que o "poder político" é algo inerente a todos os indivíduos, tanto antes como depois do ingresso na sociedade civil. Até porque, uma vez que Locke refutou a tese de Filmer de que somente os "landholders" possuíam direitos, seria um contrassenso esposar a mesma teoria.

A discussão seria interminável. Mas há que se conceder que Locke apresenta aspectos a partir dos quais podemos concluir que o seu pacto originário decorreria do consentimento de todos. As questões relativas à participação cotidiana de todos na condução do governo representação ou voto de participação - poderiam deixar dúvidas sobre sua real intenção 
política participativa. Mas estas dúvidas podem ser superadas ao lembrarmos que o sustentáculo da doutrina lockiana é a lei natural "que a todos obriga: e a razão, em que ela consiste, ensina que todos são iguais [...] que todos devem se preservar e preservar toda a humanidade [...] que o ordenamento positivo só terá legitimidade (será verdadeiro) se em conformidade com a lei de natureza" (LOCKE, 2005, II, 6, 7 e 12) ${ }^{100}$.

A legitimidade do governo decorre da sua conformidade com a lei de natureza. A base da lei de natureza não é o interesse pessoal, interesse próprio do homem, mas volta-se para um sentido maior de humanidade, para as relações harmoniosas. Isso implica igualdade e amizade. A partir disso é que se deve construir a interpretação de que o poder político observará "tão somente o bem público" (LOCKE, 2005, II, 3), evitando-se interpretações restritivas à noção de maioria e povo em Locke ${ }^{101}$.

Tully (1982, p. 160) aquiesce com a igualdade de todos, ao afirmar que o "poder" advém do "poder natural de cada homem", passando por duas fases: primeiro o "consentimento para constituir a comunidade", depois o "depósito de confiança", as incumbências determinadas ao governo, fazendo distinção entre sociedade (ou commonwealth) e governo. Mas a questão principal é a referência à expressão "cada homem" ou, melhor, ao "poder de cada homem", indicando a perfeita igualdade de todos na formalização da comunidade política. Aliás, é esta expressão que Locke utiliza ao final do Segundo Tratado: “o poder que cada indivíduo deu à sociedade quando nela ingressou não pode jamais retornar aos indivíduos enquanto durar essa sociedade [...]" (LOCKE, 2005, II, 243).

A igualdade natural não poderia ser restringida por uma igualdade política elitista, até porque Locke prega um governo de leis estabelecidas e invariáveis, a atingir "ricos e pobres", ou seja, a mesma regra para o "favorito na corte e o camponês no arado" (LOCKE, 2005, II,

\footnotetext{
${ }^{100}$ Deve-se ter em mente a realidade histórica da época. Lembramos, assim, que a propriedade privada, no Grande Século, era condição de cidadania completa. Os Tories tinham posições firmes em relação à propriedade. Os Whigs não tinham isso como princípio basilar. Também, o fato de que Locke apresentou uma explicação racional da propriedade privada antes da formação da sociedade civil - direito do homem -, não induz a conclusão de que atribua a participação política somente aos proprietários. Certo é que, à época a ideologia era de que os trabalhadores sem terra estavam ocupados - lutando pela sua subsistência-, não podendo se ocupar da vida política - a necessidade retira-lhes a racionalidade. Mas a propriedade em seu sentido estrito não é o único motivo a impelir o exercício do "direito à preservação". Isso não depende de "posse de terras", o trabalhador - o servo - pode trabalhar e ganhar seu sustento "exercendo o seu direito à subsistência" e é proprietário de si, de sua própria pessoa. Dessa forma, o exercício da liberdade não depende do direito da "propriedade de terras", pois "diferentemente do escravo, forçado a trabalhar por ter perdido o direito à vida e à liberdade, o servo pode realizar um livre contrato, submetendo-se voluntária e condicionalmente ao comando de outrem. O servo teria, portanto, assegurados os direitos fundamentais à vida e à liberdade" (JORGE FILHO, 1993, p. 99).

${ }^{101}$ Cf. Morresi (2005, p. 205-217).
} 
142). Pode ser que Locke, a despeito das conveniências políticas da época, buscasse uma igualdade política mais abrangente, isto é:

Locke talvez desejasse um novo padrão de participação política, mais aberto e mais igualitário, mas isso não está claro nos seus escritos. Nas Constituições, como em outros textos, ele parece conformar-se com a representação restrita e com a seleção econômica dos participantes das funções de governo. Ao escrever o prefácio aos Dois Tratados, um vigoroso elogio da revolução e de Guilherme de Orange, Locke parece aceitar o Parlamento da Convenção como adequado representante do povo, embora, como comenta David Wooton, "só uma minoria tivesse o direito de voto". Tudo isso é conjectura. (KUNTZ, 2004, p. 114).

O tema não é fácil e temos apenas "conjecturas" $" 102$. Neste contexto, outro ponto que se afigura importante na questão da efetiva participação, é que o consentimento voluntário dado por todos, ou melhor, que cada um, individualmente, deu na formalização da comunidade política, trará a obrigatoriedade da submissão ao que a maioria decidir. O consentimento de cada um impulsiona a comunidade política, e o poder de agir desta comunidade, como um corpo único, "se dá apenas pela vontade e determinação da maioria" (LOCKE, 2005, II, 96). É o que se depreende da seguinte passagem do Segundo Tratado:

pois sendo aquilo que leva qualquer comunidade a agir apenas o consentimento de seus indivíduos, e sendo necessário àquilo que é um corpo mover-se numa certa direção, é necessário que esse corpo se mova na direção determinada pela força predominante que é o consentimento da maioria, do contrário, torna-se impossível que aja ou se mantenha como um corpo único, uma comunidade única [...] (LOCKE, 2005, II, 96).

Locke evidencia aqui a preocupação com a unidade necessária em um corpo político e a definição de rumos a seguir. Isso implica o acatamento da decisão da maioria. $O$ ato da maioria equivale ao ato de todos. E, para evitar qualquer crítica tendenciosa Locke já se adianta em explicar que, se assim não fosse, aquele que não acatasse a decisão da maioria desvirtuaria o pacto.

Ora, o pacto original não teria sentido algum, uma vez que conceder tal liberdade no estado civil seria devolver-lhe a que dispunha "antes do pacto e como tem qualquer um no

\footnotetext{
${ }^{102}$ Conclusões sobre isso é algo muito desconfortável. Para John Dunn, é certo que Locke apresentou ideias radicais, todavia, "ele jamais teve a expectativa, ou, até onde sabemos, não teria sequer desejado uma realização, em sua época de vida, dos programas radicais de extensão do direito de voto defendido pelos Niveladores (Levellers) na Guerra Civil Inglesa [...]. No entanto, a teoria que ele expôs nos Dois Tratados era uma teoria bem radical, uma teoria de igualdade e responsabilidade política, baseando-se no julgamento de cada indivíduo adulto; e, ao longo do livro, Locke se referia à teoria como se desejasse que fosse tomada ao pé da letra" (DUNN, 2003, p. 51).
} 
estado de natureza, que pode submeter-se e consentir a quaisquer atos que julgar conveniente" (LOCKE, 2005, II, 97).

O raciocínio é simples: cada indivíduo possui o poder executivo da lei de natureza e ao mesmo tempo cada indivíduo tem o dever, pela lei de natureza, de se preocupar com a humanidade. Cada um (todos) consente (pacto) que qualquer número de homens forme a comunidade, renunciando ao poder de punir, e concorda em se submeter à decisão da maioria (governo da maioria). Todo aquele que faça parte ou more na comunidade aceita (deve aceitar) o domínio do governo (governo da maioria), obedecendo à legislação do corpo político, que possui como fonte e base a lei de natureza.

Assim, ao consentir na criação da comunidade política, o individuo fundamenta o direito da maioria, porque confia que, se não todos, pelo menos a maioria volta-se a percorrer caminhos que levam à preservação mútua. In casu, a maioria é, "na realidade, expressão não propriamente de uma soma de indivíduos, por majoritária que ela seja, mas do povo racional enquanto tal, que é o soberano por natureza" (POLIN, 2003, p. 186).

As ponderações sobre o pacto evidenciam que a criação do corpo político e o depósito de poderes se processam dentro de limites demarcados pelos "fins da sociedade política e do governo". A análise da finalidade do governo proporciona mais esclarecimentos sobre a noção de todos no processo do pacto, evidenciando a relação consentimento e obediência, como uma dinâmica de participação política como a seguir se propõe. 


\subsection{Da Comunidade Política e do Governo: fins}

$\mathrm{Na}$ argumentação lockiana, a compreensão dos objetivos da sociedade política exige a delimitação das causas que determinaram os homens a abandonar o seu estado de perfeita liberdade - estado de natureza - e formarem o corpo político.

Até aqui, muito já se falou sobre as incertezas de se viver no estado de natureza, das complicações e inconveniências advindas da executividade da "estranha doutrina", precisamente, da carência:

- de uma lei estabelecida, fixa, conhecida, recebida e aceita mediante o consentimento de todos, "medida comum para solucionar todas as controvérsias [...]" (LOCKE, 2005, II, 124);

- "de um juiz conhecido e imparcial, com autoridade para solucionar todas as diferenças de acordo com a lei estabelecida" (LOCKE, 2005, II, 125); e

- "de um poder para apoiar e sustentar a sentença quando justa e dar a ela a devida execução" (LOCKE, 2005, II, 126).

Dessa forma, não obstante as vantagens da condição natural, a existência também de alguns percalços levou os homens livres à inevitável opção racional: a união em sociedade, na intenção de fazer valer a obediência à lei de natureza (LOCKE, 2005, II, 127). As razões da opção já desenham a finalidade do governo e da sociedade civil ${ }^{103}$.

Ao tratar dos objetivos da sociedade civil, Locke busca aproximar o interesse privado, o coletivo e o público. Essa linha de raciocínio advém de que a renúncia em prol do corpo político e a formação da sociedade não invalidam a lei de natureza, a saber:

\footnotetext{
${ }^{103}$ Locke, no Segundo Tratado, enfatiza que "cada homem" ao celebrar o "pacto", ingressando na comunidade política, renuncia ao poder de "fazer o que julgar conveniente para a própria preservação e a de terceiros dentro do que permite a lei de natureza", bem como de "castigar os crimes cometidos contra essa lei" (LOCKE, 2005, II, 128). No contexto dos já analisados inconvenientes da "estranha doutrina”, a necessária renúncia volta-se, em última análise, à preservação de si e da humanidade. Solução para se retomar a lei de natureza, evitando o estado de guerra possivelmente deflagrado pelos que deixam de ouvir a razão. O objetivo da comunidade política é a "mútua preservação da vida, da liberdade e dos bens ou possessões" do ser humano, preservação então do que se denomina "genericamente de propriedade" (LOCKE, 2005, II, 87 e 132). Nosso autor conjuga o interesse particular e o bem de todos (interesse coletivo e interesse público), dado o mandamento da lei de natureza: preservar-se e a toda humanidade. A lei civil, a ser elaborada para reger as ações humanas, deve "estar em consonância com a lei de natureza", ou seja, declaradamente de acordo com a vontade de Deus, "da qual é manifestação". A conclusão é singular: como a lei fundamental da natureza é a preservação dos homens, não há lei humana ou sanção em contrário que seja válida ou aceitável (LOCKE, 2005, II, 135).
} 
As obrigações da lei de natureza não cessam na sociedade mas, em muitos casos, apenas se tornam mais rigorosas e, por meio de leis humanas, a ela se acrescem penalidades conhecidas a fim de forçar sua observância. Assim, a lei de natureza persiste como uma eterna regra para todos os homens, sejam eles legisladores ou não" (LOCKE, 2005, II, 135).

É sabido que não há um "vazio ético em Locke" 104 . A evidência da tradição medieval é patente: a relação entre o direito e a moral é característica forte no pensamento político lockiano. A lei natural é a base da lei civil, os direitos e deveres naturais - preexistentes encontrar-se-ão resguardados pela sociedade civil. Locke "enfaticamente sustentava que os direitos e deveres são morais, intrínsecos e anteriores à lei; e os governos são obrigados a realizar pela lei aquilo que é natural e moralmente certo" (SABINE, 1964, p. 520).

A formalização da sociedade civil não estaria acrescentando ou modificando substancialmente as relações do estado de natureza. Também não há delegação de poderes absolutos ao governo, pois a constituição de um corpo político visa propiciar aos homens uma legislação única e conhecida (poder legislativo) e uma judicatura (poder executivo da lei), para se retomar o equilíbrio das relações humanas, nas suas múltiplas interações.

O fim da comunidade é a "paz, a segurança e o bem público do povo" (LOCKE, 2005, II, 133). Na consecução destes objetivos, Locke, avesso a governos absolutos, traça algumas regras, sob pena de não se alcançar a finalidade proposta.

A primeira necessidade que aponta é a de se estabelecer uma lei - daí a importância da figura do legislador - ante a máxima: "governo de leis e não de homens". As características desta lei, na doutrina lockiana, mostram duas grandes preocupações: a primeira, com aqueles que se deixam levar por paixões e deixam de ouvir a razão, descumprindo a lei de natureza; e a segunda, com a necessária estabilidade social e a segurança jurídica da comunidade política.

A opção lockiana pelo "governo de leis" explica-se pelo fato de que a lei de natureza, por não ser escrita, "não se pode encontrar senão no espírito dos homens", e aqueles que "a citam ou a aplicam erroneamente", por se deixarem levar por paixão ou interesse próprio, não serão facilmente convencidos de seu equívoco, se não houver juiz autorizado a determinar os

\footnotetext{
${ }^{104}$ A lembrar, Locke enfatiza que a base da lei de natureza não é o interesse próprio de cada um e, na argumentação e exemplos coligidos nos Ensaios sobre a Lei de Natureza, procura evidenciar que aqueles que a seguem tendem a buscar "não a própria vantagem, mas a da república e de toda humanidade" (LOCKE, 2007, p. 160). Como visto, a lei de natureza já determinava ao homem o "quadro completo de direito e deveres humanos" e assim, "tudo que é certo ou errado o será eternamente" e, como conseqüência, o direito positivo nada acrescenta "à qualidade moral dos diferentes tipos de conduta, limitando-se a fornecer meios para um cumprimento efetivo", pois no "estado de natureza todos os homens devem proteger seus interesses da melhor forma possível, mas o direito às próprias coisas e o dever de respeitar as que pertencem a outros é tão completo como pode vir a tornar-se sob o governo" (SABINE, 1964, p. 519).
} 
direitos e limitar as posses dos que sob ela vivem, "sobretudo quando todos são também - e em causa própria - juízes, intérpretes da mesma [...]" (LOCKE, 2005, II, 136). Na presente linha, ante as possíveis contendas entre os homens, segundo Locke, a lei civil dever ser:

estabelecida, fixa e conhecida, recebida e aceita mediante consentimento comum enquanto padrão da probidade e da improbidade, e medida comum para solucionar todas as controvérsias entre eles (LOCKE, 2005, II, 124).

Cônscio de algumas dificuldades humanas, a explicação para a formação do corpo político e da necessidade de lei escrita é simples:

Isso porque, embora a lei de natureza seja clara e inteligível a todas as criaturas racionais, contudo, por serem os homens influenciados por seus interesses próprios e ignorarem-na por falta de estudo, não conseguem reconhecê-la como uma lei a ser obrigatoriamente aplicada em seus casos particulares (LOCKE, 2005, II, 124).

A presente assertiva, num primeiro momento, chama a atenção para o elemento psicológico do ser humano e para a necessidade de se pensar na formação deste: "influências" "falta de estudo" e "interesse próprio". Num segundo momento, evidencia as razões pelas quais os homens, através do pacto, instituíram um corpo legislativo, evidenciando também a enorme importância da lei na estrutura organizacional lockiana.

Locke apresenta uma noção positiva de lei, seja no estado de natureza, seja no estado civil: a lei não restringe, e sim delimita, resguardando a liberdade: "onde não há lei não há liberdade", pois ser livre significa estar livre de "restrição e de violência de terceiros", afinal, “quem poderia se dizer livre se estivesse exposto ao arbítrio de qualquer um?” (LOCKE, 2005, II, 57) ${ }^{105}$. A liberdade, então, consiste na disposição e ordenação das ações humanas, de acordo com a sua vontade própria, "dentro da prescrição das leis sob as quais vive [...]" (Ibid.).

A escolha é racional. Os homens livres e iguais encontram-se frente a duas opções: terem suas ações pautadas por uma lei escrita e conhecida, garantindo a liberdade de todos ou, ausente um ordenamento jurídico, submeterem-se ao capricho e à vontade arbitrária de outrem. Assim, na preservação da liberdade e da igualdade, a comunidade política, na sua estrutura, requer:

\footnotetext{
${ }^{105}$ No que se refere ao vínculo entre lei e liberdade no pensamento de Locke, Frateschi resume que, "no estado de natureza, os homens são livres justamente pelo fato de estarem submetidos tão somente à lei da razão, ou seja, a liberdade advém do fato dos homens serem racionais, e sua razão (e não outro poder estranho) é capaz de instruí-lo sobre a lei pela qual eles devem se governar (II, 63). A liberdade civil, a seu turno, consiste em viver sob uma regra permanente, que é comum a todos os membros da sociedade e elaborada pelo poder legislativo estabelecido por meio do consentimento (II, 22) [...]" (FRATESCHI, 2008, p. 343).
} 
- o corpo legislativo, no sentido restrito de elaboração de leis (prévias, conhecidas e com sanções);

- a instituição de um juiz conhecido e imparcial, com autoridade para solucionar todas as eventuais controvérsias que se instalem, nos termos da lei, previamente estabelecida;

- a criação de mecanismos para apoiar e sustentar as sentenças, garantindo a execução destas.

A importância do poder da sociedade instituída e do legislativo é ressaltada por Locke na seguinte passagem:

Contudo, embora quando entrem em sociedade os homens entreguem a igualdade, a liberdade e o poder executivo que possuíam no estado de natureza nas mãos da sociedade, para que deles disponha o legislativo segundo o exija o bem da sociedade, contudo, como cada qual o faz com a intenção de melhor conservar a si mesmo, a sua liberdade e propriedade pois não se pode supor que uma criatura racional mude propositadamente sua condição para pior -, o poder da sociedade ou o legislativo por esta constituído jamais pode supor-se estenda-se para além do bem comum" (LOCKE, 2005, II, 131) ${ }^{106}$.

Considerando a importância do "governo de leis" como uma forma de participação do próprio homem na vida civil (escolha e consentimento) e visando coibir eventual arbítrio do poder, entre outros males, Locke, no Segundo Tratado sobre o Governo, tece considerações sobre as possíveis "formas de uma sociedade política" (Capítulo X) e sobre a "extensão do poder legislativo" (Capítulo XI). Além disso, na mesma linha, analisa o poder legislativo, executivo e o federativo (Capítulo XII), com o objetivo de evitar a concentração do poder político.

\footnotetext{
${ }^{106}$ Para Locke a instituição do poder legislativo e do poder executivo busca resolver os inconvenientes da execução da estranha doutrina. Os homens renunciam assim ao poder de interpretar e de executar a lei de natureza (de castigar) (LOCKE, 2005, II, 128-130). Tal renúncia torna-se adequada e necessária, impondo à sociedade o objetivo da preservação mútua de todos os integrantes da comunidade política (LOCKE, 2005, II, 131).
} 


\subsubsection{Das Formas e dos Poderes de uma Comunidade Política}

Locke, no Capítulo X do Segundo Tratado, retomando a tradicional teoria aristotélica, diferencia três formas de governo para a comunidade política, que são definidas de acordo com o detentor do poder de legislar:

- democracia: governo de muitos - desde o momento inicial em que os homens se uniram em sociedade, a maioria, naturalmente, possui o poder da comunidade, podendo empregar tal poder para elaborar leis com periodicidade e fazer executar tais leis por funcionários designados (LOCKE, 2005, II, 132).

- oligarquia: governo de alguns - o poder de elaborar leis encontra-se depositado "nas mãos de pequeno número de homens seletos e de seus herdeiros ou sucessores" (LOCKE, 2005, II, 132).

- monarquia: governo de um - a atribuição legislativa centra-se em um único homem; pode ser monarquia hereditária, quando nas mãos dele e de seus herdeiros, ou eletiva, quando, após sua morte, o poder "apenas de designar um sucessor retorna à maioria" (LOCKE, 2005, II, 132).

Locke não declina qual é a melhor forma de governo ${ }^{107}$. Para ele a forma escolhida não tem grande relevância na estrutura do Estado, pois a questão vital é estabelecer, pelo consentimento, o governo de leis que regem a comunidade política, a saber:

[...] a forma de governo depende de quem é o depositário do poder supremo, que é o legislativo, e sendo impossível conceber que um poder inferior possa regular um superior, ou que outro senão o poder supremo elabore as leis, a forma da sociedade política depende de quem é o depositário do poder de elaborar leis (LOCKE, 2005, II, 132).

$\mathrm{Na}$ esteira da tradição iniciada por Aristóteles e Políbio, Locke, a par das formas acima mencionadas, admite a possibilidade de se estabelecerem formas mistas ou compostas de governo, “conforme achar conveniente" (LOCKE, 2005, II, 132).

\footnotetext{
${ }^{107}$ Sobre as distinções de modalidades de governo, Paulo César Nodari observa que "não fica claro qual a forma de governo que Locke defende. [...] Não obstante, diante de sua crítica ao absolutismo, ao poder limitado do Estado e à supremacia do poder legislativo sobre o executivo, pode-se concluir que Locke defende e racionaliza o regime da monarquia constitucional e representativa. Locke passou para a história como o teórico da monarquia constitucional e representativa. (NODARI, 1998, p. 143-144). Na mesma linha, Vladimir L. Jorge, citando David Held, observa que para Locke a forma mais compatível com o governo civil é a forma mista, pois a segurança almejada requer "um estado no qual o poder público está legalmente circunscrito e divido. Held explica que 'Locke acreditava na conveniência de uma monarquia constitucional com um poder executivo e uma assembléia parlamentar com direito de legislar [...]”" (JORGE, 2009, p. 107).
} 
Contrário aos sistemas absolutistas, nosso autor trabalha a dicotomia liberdade versus opressão, evidenciando que a sua maior preocupação é demonstrar que a legitimidade da autoridade política advém do consentimento do povo. Para Locke, a monarquia absoluta não é compatível com a sociedade civil, e o poder absolutista é pior que os inconvenientes do estado de natureza:

Fica, portanto, evidente que a monarquia absoluta, que alguns consideram o único governo no mundo, é de fato incompatível com a sociedade civil, e portanto não pode ser, de modo algum, uma forma de governo civil. Pois sendo o fim da sociedade civil evitar e remediar aqueles inconvenientes do estado de natureza [...] sempre que houver pessoas desprovidas de uma tal autoridade à qual apelar para a decisão de quaisquer diferenças entre elas, essas pessoas se encontrarão no estado de natureza, do mesmo modo qualquer príncipe absoluto em relação àqueles que estiverem sob seu domínio" (LOCKE, 2005, II, 90) ${ }^{108}$.

A sujeição a um tirano, que não cumpre ou não se sujeita à lei, reduz os homens ao estado de natureza, ou seja, gera uma situação em que não há governo civil. Sob o arbítrio ou capricho de um déspota, os homens "não têm a quem apelar". Razão pela qual, como observado, melhor seria o estado de natureza, em que se poderia exercer a "estranha doutrina".

A importância que atribui à lei é o elemento-chave diferenciador das formas de governo apresentadas, pois estas dependem sempre de quem tem o poder de elaborar as leis. O poder legislativo é o poder supremo da comunidade política, precisamente, um poder/função sagrado e intocável nas mãos daquele a quem a comunidade o confiou.

Desta forma, não pode "edito algum de quem quer que seja, seja de que forma concebido ou por que poder apoiado, ter força e obrigação de lei se não for sancionado pelo legislativo escolhido e nomeado pelo público", pois, se assim não fosse, faltaria à lei o que lhe é absolutamente necessário à sua natureza de lei: “o consentimento da sociedade" (LOCKE, 2005, II, 134).

Locke ainda enfatiza que a constituição da sociedade política - corpo político - a que se refere equivale à commonwealth (bem comum, coisa pública). Segundo o autor, a sociedade política deve ser compreendida como a civitas dos latinos e, no vocabulário inglês,

\footnotetext{
108 Segundo Pierre Manent, "Locke considerava que a monarquia absoluta era não apenas um mau regime político, não apenas um regime ilegítimo, mas fundamentalmente algo que não era, em absoluto, um regime político, deixando os homens num estado de natureza pior do que o estado de natureza original" (MANENT 1990, p. 83).
} 
"o termo que melhor corresponde, e que com mais adequação expressa tal sociedade de homens, é sociedade política [commonwealth] [...]" (LOCKE, 2005, II, 133) ${ }^{109}$.

Na sequencia, Locke passa a analisar os poderes fundamentais da comunidade política. Percebe-se que, sempre no intuito de estabelecer limites ao poder político, nosso autor vê a necessidade de uma certa partilha do poder, estabelecendo os seguintes poderes fundamentais na estrutura institucional do Estado: o legislativo, o executivo e o federativo.

Locke volta-se para uma concepção antiabsolutista do poder, tecendo uma teoria voltada à decomposição e enfraquecimento do poder monárquico. Procura assim, demonstrar a necessidade do exercício do poder por pessoas distintas para evitar déspotas e tiranos. A execução de certas tarefas inerentes ao poder da comunidade política por mãos distintas afigura-se como uma garantia ao exercício da liberdade dos súditos.

A origem do poder legislativo e do poder executivo encontra-se no próprio pacto, face à necessária renúncia ao poder executivo da lei de natureza, a saber:

E, assim, a sociedade política passa a ter o poder de estabelecer qual punição, segundo seu julgamento, caberá às diversas transgressões cometidas entre os membros dessa sociedade (que é o poder de elaborar leis), assim como tem o poder de punir qualquer dano cometido contra qualquer um de seus membros por alguém que não pertence a ela (o que é o poder de guerra e paz) [...] juntamente com o julgamento dos delitos que colocou nas mãos do legislativo [...], também cedeu ao corpo político o direito de usar a força dele para a execução dos julgamentos desse mesmo corpo político [...]. Temos aqui a origem dos poderes legislativo e executivo da sociedade civil [...]" (LOCKE, 2005, II, 88).

Como visto, o poder legislativo tem a prerrogativa de criar as leis - poder supremo da comunidade -, cabendo-lhe o direito de estabelecer como se deverá utilizar a força da comunidade no sentido da preservação dela própria e de seus membros (LOCKE, 2005, II, 143). Para esse mister, tem a competência de elaboração das leis prévias, perenes e conhecidas, visando a estabilidade jurídica e a paz e a liberdade dos homens.

Dos poderes enunciados por Locke, o legislativo é "a primeira providência positiva e fundamental de toda sociedade", pois este poder, sagrado e inalterável em cujas mãos a

\footnotetext{
${ }^{109}$ Locke explica que a expressão commonwealth é utilizada para evitar ambiguidades, pois o desenho da sociedade de homens que tenciona não equivale ao termo comunidade (community) ou cidade (city), "uma vez que podem existir comunidades subordinadas em um governo e, entre nós, o termo cidade carrega uma noção muito diversa da de uma sociedade política [...]", razão pela qual emprega o "termo sociedade política, ou corpo político [commonwealth], no sentido em que vejo ser utilizado pelo rei Jaime I, e considero ser este o seu significado genuíno; e se a alguém não agradar, estou pronto a substituí-lo por um termo melhor" (LOCKE, 2005, II, 133).
} 
comunidade o tenha depositado, é o "grande instrumento e meio" para que se possa obter a paz e a segurança de todos na comunidade política.

Para Locke, trata-se de verdadeiro instrumento para garantir a efetividade da lei de natureza, prescrição "primeira e fundamental, destinada a governar até mesmo o próprio legislativo [...]" (LOCKE, 2005, II, 134). O poder político supremo - poder de elaborar leis -, em Locke, configura-se "como um poder derivado e não como poder originário. Assim, dos poderes pertencentes aos homens no seu estado de natureza derivam os dois poderes típicos da comunidade, o legislativo e o executivo" (OLIVEIRA, 2008, p. 174) ${ }^{110}$.

O poder legislativo é escolhido e nomeado pelo povo, como condição necessária para assegurar o consentimento à lei (como ao pacto). Isto é importante porque a relação de obediência a que alguém está obrigado pelos "vínculos mais solenes" termina nesse poder supremo e é regida pelas leis que ele promulga. É através do legislativo que os membros de uma sociedade política "se unem e se compõem num corpo vivo e coerente". Verdadeira "alma que dá forma, vida e unidade à sociedade política e de que os diversos membros extraem sua influência, simpatia e conexão mútuas" (LOCKE, 2005, II, 212).

Locke procura destacar a imbricação entre consentimento, obediência e outorga de autoridade, pois a "alma da sociedade" é um poder consentido, dado em depósito para determinado fim, com o conseqüente dever de obediência ao mesmo, na medida em que não se afaste dos fins propostos, como se depreende da seguinte passagem:

Pois, consistindo a essência e a união da sociedade em ter uma só vontade, ao legislativo, uma vez estabelecido pela maioria, cabe expressar e, por assim dizer, sustentar essa vontade. A constituição do legislativo é o primeiro e fundamental ato da sociedade, pelo qual se provê à continuação de sua união, sob a direção das pessoas e dos vínculos das leis elaboradas por pessoas autorizadas a tal mediante o consentimento e nomeação por parte do povo, sem o que nenhum homem ou grupo de homens, entre si, pode ter autoridade de elaborar leis que obriguem a todos os demais (LOCKE, 2005, II, 212).

A partir do pacto, ninguém está dispensado da obediência ao legislativo, tampouco obrigado a um tipo de obediência contrária às leis promulgadas, ou além do admitido por estas. Isso remonta à própria natureza e finalidade do pacto ou pactos, uma vez que,

\footnotetext{
${ }^{110}$ Os homens, segundo Locke, se conformam em uma sociedade para assegurar suas propriedades: vida, liberdade e bens. E, notadamente, para a paz e segurança almejadas é imprescindível a normatização (regras de conduta) consentida pela comunidade. Dessa forma, todo homem, ao consentir com outros em formar um único corpo político sob um governo único, assume a obrigação - dever de obedecer à lei civil. Assim, a lei positiva torna-se o instrumento para alcançar o objetivo da sociedade, devendo ser baseada na lei natural primeira e fundamental, sob pena de não possuir legitimidade. Locke trabalha, simultaneamente, com a lei natural e com a lei positiva, ambas voltadas para a proteção da sociedade e de seus integrantes.
} 
primeiramente, consentiu-se na formalização da sociedade e, agora, no estabelecimento do governo-poder, com objetivos predeterminados.

A escolha do legislativo envolve a delegação de poder, baseada na relação de confiança (trust) de que o poder legislativo irá cumprir o seu papel: possibilitar a retomada da lei natural, propiciando ao ser humano o dever/direito de se preservar e de preservar a humanidade. O objetivo então, em última instância, é a paz e a segurança que havia no estado de natureza. O poder legislativo tem seus limites restritos ao bem da sociedade (LOCKE, 2005, II, 135).

O legislativo, em suma, nada mais é do que o poder conjunto de todos os membros da sociedade, que foi confiado a uma pessoa ou grupo de pessoas para exercer a função de legislador, função esta relevante num "governo de leis". Consequentemente, este poder não poderá ser maior "do que aquele que tais pessoas tinham no estado de natureza".

No capítulo XI do Segundo Tratado, com nítida preocupação em tolher eventuais abusos e ou excessos de poder, Locke, discorrendo sobre a "extensão do poder legislativo", traça os seguintes limites:

- O poder legislativo não é "absoluto e ou arbitrário sobre a vida e os haveres do povo". A chave da limitação do poder, na ótica lockiana, encontra aqui o seu ponto forte: ninguém cede mais poder do que possui, ou seja, se ninguém tem o poder de destruir sua vida ou de outrem, bem como de tirar a propriedade alheia, tampouco o legislativo terá tal poder. Com efeito, trata-se de um "poder concedido" com finalidade específica. Reflete o poder conjunto de cada membro da sociedade depositado nas mãos de uma pessoa ou de um grupo de pessoas. Logo, não pode "exceder o poder que tinham essas pessoas no estado de natureza, antes de entrarem em sociedade e cederem-no à comunidade [...]. O poder legislativo, em seus limites extremos, limitase ao bem público" (LOCKE, 2005, II, 135). Locke dá ênfase ao governo de leis e não de homens, e, visando a necessária segurança, igualdade e liberdade de todos, as leis

não poderão variar nos casos particulares, mas segundo uma mesma regra para ricos e pobres, para o favorito da corte e o camponês no arado (LOCKE, 2005, II, 142).

- Princípio da anterioridade da lei. A sociedade deve ser governada por leis fixas, promulgadas e previamente conhecidas. Da mesma forma, os juízes devem ser conhecidos, imparciais e autorizados. A clareza da redação da lei também é fator importante, pois leis expressas e determinadas evitam ambiguidades e equívocos nas 
resoluções das eventuais questões a serem julgadas. Na busca da segurança jurídica, Locke estabelece que o governo deve ser exercido através de lei que não poderá variar nos casos particulares: a mesma regra para todos, indiscriminadamente, pois é importante que o governado conheça de antemão o seu dever e viva a salvo dentro dos limites das leis. Não se pode, dessa forma, governar através de decretos arbitrários, caprichosos e extemporâneos. O arbítrio ou governo sem leis fixas previamente estabelecidas "não se harmonizam com os fins da sociedade e do governo, por cujas vantagens se abandonou o estado de natureza", ou seja:

Tanto o poder absoluto e arbitrário como o governo sem leis e estabelecidas e fixas não podem ser compatíveis com os fins da sociedade e do governo. [...] Não cabe supor que pudessem pretender, tivessem eles poder para tal, conferir a uma ou mais pessoas poder absoluto e arbitrário sobre suas pessoas e haveres, e depositar, nas mãos do magistrado, uma força para impor arbitrariamente sobre eles sua ilimitada vontade. Isso significaria colocarem-se em situação pior que a do estado de natureza [...] supondo que se tenha oferecido ao poder absoluto e arbitrário e à vontade de um legislador, teriam desarmado a si mesmos e armado a este, para se tornarem sua presa quando bem lhe aprouvesse. (LOCKE, 2005, II, 137)

- Finalidade predeterminada: as leis devem visar o bem do povo. Assim, de um lado, os governados conhecem previamente o conteúdo da lei a regrar suas condutas e, de outro, os que detêm o poder devem se ater à finalidade da lei. É necessário então, para a perfeita harmonia e estabilidade da sociedade, que

os governantes se mantenham em seus devidos limites sem que se vejam tentados, pelo poder que têm nas mãos, a empregá-lo para fins, e por meios, ignorados pelos homens e que não seriam aceitos voluntariamente por estes (LOCKE, 2005, II, 137).

- Com certa especificidade, Locke prescreve que o poder supremo não pode tomar parte da propriedade (ou outra possessão) do governado sem o seu próprio consentimento. A finalidade da sociedade é a preservação da propriedade (das propriedades), ninguém pode tolher seus haveres. No presente particular, Locke critica governos, legislativos e assembleias permanentes (função perpétua - nas mãos de uma monarquia), pois pressente o risco de julgarem conforme interesse distinto ou contrário do desiderato da comunidade. O poder é confiado para que o governo assegure a propriedade - não para tomá-la. Questão interessante vem a ser o direito de propriedade e a tributação (questionamento de eventual confisco), pois, consciente de que os governos não podem sustentar-se sem grandes encargos, admite a tributação 
adequada a manter o governo ${ }^{111}$. A tributação deve ser proporcional aos próprios haveres do membro da sociedade, e sempre mediante o consentimento da maioria, dado diretamente ou através de representantes por ela escolhidos, sob pena de se tolher o direito de propriedade e subverter o fim do governo. Aqui, Locke demarca o privado e o público, e conclui que nem um, nem outro (governo ou governado), sem o consentimento necessário, poderá invadir o espaço (propriedade) alheio. A lembrar, no Capítulo V, Locke apenas permite a "ocupação" de terras "sem dono", descartando a possibilidade de eventual invasão de terras de uso coletivo ou que possivelmente pertençam ao Estado.

- O legislador não pode transferir o poder de fazer leis para quem quer que seja. Uma vez que o legislativo já é um poder delegado - depositário da confiança do povo -, aqueles que detêm essa confiança, que se exprime no poder de elaborar leis, não poderão transmiti-la a outrem. O poder legislativo deriva do povo, por uma concessão ou instituição positiva e voluntária para elaborar leis e não para fazer legisladores, não podendo haver transferência da sua autoridade, do seu encargo de elaborar leis. Cabe ao povo a faculdade de "designar a forma da sociedade política, que se dá através da constituição do legislativo, e indicar em que mãos será depositado" (LOCKE, 2005, II, 141). Locke procura ser preciso na relação entre obediência - consentimento e poder, estabelecendo-a como uma forma próxima a uma participação na "coisa pública":

E quando o povo disser: submeter-nos-emos às regras e seremos governados pelas leis estabelecidas por tais homens e sob tais formas, ninguém mais poderá dizer que outros homens devam elaborar leis para o povo, e tampouco pode ser este submetido a nenhuma lei, senão àquelas promulgadas pelos indivíduos escolhidos e autorizados para formular as leis da sociedade (LOCKE, 2005, II, 141).

Locke sintetiza a importância do legislativo e da autoridade da lei, asseverando que as obrigações deste poder são "encargos conferidos pela sociedade e pela lei de Deus e da natureza", seja qual for a forma de governo, fixando o "governo com leis estabelecidas e promulgadas", estabelecendo diretrizes para evitar eventual uso indevido do poder político.

\footnotetext{
${ }^{111}$ Locke, ao refutar o confisco e esclarecer o seu conjunto de ideias sobre a obediência, traz um exemplo para demonstrar que mesmo o poder absoluto, onde se fizer necessário, é balizado pela razão e fins que certos casos exigem. Assim, explica que as relações envolvendo o exército exigem disciplina marcial, impondo obediência absoluta ao comando superior, e que a desobediência "ou contestação até aos mais perigosos ou irracionais destes comandos implica a morte justa do infrator"; no entanto, nenhum general, que pode vir a condenar um subalterno "à morte por desertar seu posto ou não obedecer às suas ordens mais desesperadoras", poderá exigir um tostão dos haveres do soldado ou "apoderar-se de uma ínfima parte de seus bens" (LOCKE, 2005, II, 139).
} 
No Capítulo XII, segundo observa Fábio K. Comparato, Locke criticando o excesso de poder dos governantes e procurando enfatizar o papel do legislativo, apresenta a seguinte proposta de reorganização do Estado, dos poderes públicos:

No plano vertical, isto é, nas relações entre governantes e governados, nenhum governo tem legitimidade, em circunstância alguma, para reduzir ou, menos ainda, suprimir a vida, as liberdades e as posses dos cidadãos (...). A razão de ser da sociedade política é justamente a preservação dos direitos naturais dos indivíduos, e se essa garantia, assevera Locke, só pode ser dada pela lei, o órgão público supremo, sagrado e inalterável, na sociedade política, só pode ser o legislativo.

(...)

No plano horizontal, o modo mais eficaz de limitar o poder estatal consiste em dividi-lo. A máxima tradicional recomenda dividir para melhor dominar. Locke inverte os seus termos: é preciso dividir o poder para melhor controlálo. Ele, e não Montesquieu, é o verdadeiro criador do sistema de separação de poderes nos tempos modernos. Montesquieu, aliás, tinha consciência de que nada propunha de novo: a tese da divisão de poderes é exposta num capítulo consagrado, como diz o título, à Constituição da Inglaterra (COMPARATO, 2006, p. 217-218).

Locke recomenda a separação entre os que elaboram a lei - legislativo - daqueles que irão executá-la ${ }^{112}$. A função de zelar pela execução da lei deve ser atribuída a outro órgão: o poder executivo, que pode e deve atuar de forma permanente. A racional opção decorre da possível e inegável fragilidade humana (tentação do poder), ou de isentar-se de sua obediência - evitando interesses distintos dos da sociedade.

As leis elaboradas possuem força constante e duradoura, requerendo perpétua execução ou assistência, sendo necessário um poder permanente para cuidar da execução da lei. Isso reforça a necessidade da separação entre poder legislativo e poder executivo. Como explica Locke, na seguinte passagem:

como essas leis devem ser constantemente executadas e sua força deve vigorar para sempre, podem ser elaboradas em pouco tempo e, portanto, não é preciso que o legislador se mantenha para sempre, uma vez que nem sempre terá ocupação. [...] pode constituir uma tentação demasiado grande para a fragilidade humana capaz de assenhorear-se do poder que as mesmas pessoas que têm o poder de elaborar leis tenham em mãos o de executá-las, com o que podem isentar-se da obediência às leis que fazem e adequar-se a

\footnotetext{
${ }^{112}$ Segundo Antonio Carlos dos Santos, Locke teria sido o primeiro a pensar, no mundo moderno, o poder partilhado. No pensamento lockiano, "deveria haver: o poder supremo, que é o legislativo, encarregado de instituir as leis; o poder executivo, destinado a executar as tarefas pensadas pelo legislador; por fim o federativo, dedicado às tarefas das relações internacionais. Ainda, os dois últimos poderes poderiam estar subordinados a um único magistrado, desde que o legislativo mantivesse sua força e independência dos demais, o que significa, em última instância, que a sociedade civil controla, de certa forma, o poder executivo quanto aos possíveis abusos" (SANTOS, 2008, p. 268).
} 
lei, tanto no elaborá-la como no executá-la, à sua própria vantagem particular, passando com isso a ter um interesse distinto daquele do resto da sociedade política, contrário aos fins dessa sociedade e desse governo". (LOCKE, 2005, II, 143).

Locke, temendo o poder despótico, propôs o poder partilhado, ressaltando a necessidade de que o poder legislativo e o poder executivo estejam em mãos diferentes, como condição para que todos estejam submetidos à obediência das leis da comunidade. Na visão lockiana, a desconcentração do poder traria a elaboração de leis imparciais e de juízes também imparciais.

Pensando na importante questão da segurança jurídica, Locke entende "desnecessário e inconveniente que o poder legislativo esteja sempre reunido", mas é extremamente necessário que o poder executivo "seja permanente", pois nem sempre se faz necessária a elaboração de novas leis, mas a necessidade de executar as existentes (enquanto vigentes) é constante (LOCKE, 2005, II, 153).

Observa-se que o poder legislativo está fora do alcance da normatização, enquanto poder supremo - poder constituinte -, todavia, essas diversas pessoas reunidas em assembleia voltadas à elaboração das leis, "depois de as terem feito, separando-se novamente", ficam sujeitas às leis que formularam, o que contribuirá "para que tenham o cuidado de elaborá-las visando o bem comum" (LOCKE, 2005, II, 143).

Embora Locke pretenda a partilha do poder, estabelece uma forte hierarquia entre o poder legislativo e o executivo, atribuindo supremacia ao primeiro, tão somente pelo fato de "fazer leis válidas para todos os membros da sociedade", estabelecendo regras a suas ações, bem como "concedendo o poder de execução onde quer que sejam transgredidas". Por esse mister, o legislativo deve ser o poder supremo, "e todos os demais poderes depositados em quaisquer membros ou partes da sociedade devem derivar dele ou ser-lhe subordinados" (LOCKE, 2005, II, 150) ${ }^{113}$. A hierarquia é patente, pois, se é verdade que

o legislativo confia a execução das leis que elabora a outras mãos, mantém o poder de retirá-la dessas mãos se encontrar causas para tanto ou a fim de punir qualquer má administração contrária às leis. $\mathrm{O}$ mesmo vale também em relação ao poder federativo, sendo este e o executivo ambos ministeriais

\footnotetext{
113 A subordinação estabelecida por Locke afasta-o da teoria da divisão de poderes de Montesquieu. O poder legislativo é o poder máximo, isso estabelece uma hierarquia entre o legislativo e o executivo. Dessa forma, o poder executivo, "cujas funções devem ser desempenhadas pelo Rei, deve estar subordinado ao legislativo. $\mathrm{O}$ Executivo não participa do processo legislativo, pois ele não possui poder de veto [...]. Portanto, não encontramos na teoria lockiana nenhum mecanismo de limitação e controle do Poder Legislativo" (JORGE, 2008, p. 111).
} 
e subordinados ao legislativo, que, tal como demonstramos, é supremo numa sociedade política constituída (LOCKE, 2005, II, 153).

Na demarcação da superioridade do poder supremo, Locke enfatiza que, embora o executivo tenha o poder de dispensar e convocar o legislativo, isto não lhe confere nenhuma superioridade, constituindo apenas um encargo fiduciário atribuído para a segurança do povo $^{114}$. Assim, nas situações em que não for possível prefixar períodos exatos de volta e duração para as reuniões do legislativo correspondentes às exigências da comunidade, o melhor remédio é a confiança na "prudência de alguém que estivesse sempre presente e cuja tarefa fosse a de cuidar do bem público" (LOCKE, 2005, II, 156).

A par do legislativo e do executivo, Locke reconhece ainda a necessidade de um outro poder: o federativo, a quem incumbe a gestão da segurança e do interesse do público externo, atribui-lhe o "poder de guerra e paz, de firmar ligas e promover alianças e todas as transações com todas as pessoas e sociedades políticas externas" (LOCKE, 2005, II, 146). A ação do poder federativo goza de certa flexibilidade, seu proceder deve ser pautado pela prudência e pela sabedoria daqueles em cujas mãos se encontra para ser gerido em favor do bem público.

O poder federativo cuida das questões de ordem externa da comunidade e, "embora realmente distinto do poder executivo", pode ser compreendido como parte do mesmo, pois "dificilmente podem ser separados e depositados, ao mesmo tempo, nas mãos de pessoas diferentes". A sua linha de raciocínio baseia-se no fato de que o exercício do poder executivo e do federativo exige a "força da sociedade", sendo impraticável depositar tal força em mãos diferentes, "que possam agir separadamente, com o que a força do público estaria sob comandos diferentes, o que poderia causar, num momento ou outro, desordem e ruína" (LOCKE, 2005, II, 148).

O papel do poder judiciário é algo curioso, na estrutura organizacional do Estado delineada por Locke. A figura do juiz, tantas vezes mencionada por Locke ao refletir sobre os inconvenientes da "estranha doutrina", não foi objeto de estudo separado, ao lado dos três

\footnotetext{
${ }^{114}$ Na leitura de Pierre Manent, a supremacia do poder legislativo é explicável pelos próprios acontecimentos políticos vivenciados por Locke, ou seja, a distribuição igualitária do poder "entre o legislativo e o executivo não podia ser concebida enquanto se considerasse que a soberania residisse no rei, como acontecia à época em que Locke escreveu (o que já não era absolutamente o caso no momento em que ele publicou seus escritos)". O pensamento lockiano, como um "projeto liberal", passa a exigir que se refute "de imediato a idéia de soberania real. Ora, a uma soberania absoluta não se pode opor senão uma soberania absoluta: à soberania do rei, a do povo. A soberania do povo, na qualidade de absoluta, não era, em princípio, mais propícia à separação dos poderes do que a soberania do rei, mas, como o povo soberano não podia governar diretamente, e como a assembléia de seus representantes tampouco era apropriada para governar, um regime baseado na soberania do povo tinha praticamente necessidade de outro poder que não o soberano" (MANENT, 1990, p. 84-85).
} 
poderes por ele definido. Locke analisou e diferenciou apenas o legislativo, o executivo e o federativo, não mencionando o judiciário como um poder distinto. Paulo César Nodari observa que "o judiciário não era, para Locke, separado, mas atributo geral do estado. Locke reconheceu que o poder judiciário deveria ser imparcial e íntegro, conhecido e autorizado, mas não teria sentido colocá-lo ao lado dos poderes legislativo e executivo" (NODARI, 1998, p. $149-150)^{115}$.

Na leitura de Norberto Bobbio, Locke teria reduzido os três poderes tradicionais a apenas dois - o legislativo e o executivo -, incluindo o judiciário no legislativo, pois os "legisladores e juízes têm a mesma função: estabelecer o direito, isto é, as normas de convivência. Pouco importa que os primeiros estabeleçam de modo abstrato e os segundos em casos concretos: a distinção é qualitativa" (BOBBIO, 1997, p. 232-233).

O importante para Locke, segundo Norberto Bobbio, é a diferença substancial entre o legislativo e o executivo, pois, enquanto aquele "discrimina o que é justo e injusto", regrando as ações humanas, o executivo aplica "a força para assegurar a observância das regras decididas, preventivamente, pelos legisladores e, em caso de conflito, pelos juízes”. Assim, "a função do juiz imparcial é exercida, na sociedade política, eminentemente pelos que fazem as leis, porque um juiz só pode ser imparcial, se existem leis genéricas, formuladas de modo constante e uniforme para todos" (BOBBIO, 1997, p. 232) ${ }^{116}$.

No prisma lockiano, juiz e legislador, na sociedade política, voltam-se ao mesmo fim: “estado de paz entre os que dela fazem parte, da qual o estado de guerra está excluído pela

\footnotetext{
115 J. W. Gough, analisando "a separação de poderes e soberania", lembra que a distinção de poderes e a supremacia do legislativo não é uma inovação lockiana. Todavia, Locke apresenta um ponto original, o "uso do termo federativo, o único termo que não era adotado pelos outros escritores", assim, "nem Locke, nem Montesquieu podem reivindicar terem realmente dado origem à idéia da separação de poderes, embora não haja dúvida de que a efetiva popularização da teoria deveu-se muito mais a seus trabalhos [...]" (GOUGH, 2003, p. 227).

${ }^{116}$ Peter Laslett, ao analisar os "três poderes" enunciados por Locke, considera que ele não "tinha em mente uma doutrina", não apresentando nenhuma teoria "da importância ou da necessidade da permanência perpétua desses poderes em mãos separadas para preservar a liberdade, garantir os direitos ou manter a constituição sadia, em harmonia e concórdia". Laslett baseia a sua afirmação em dois pontos: 1) Para Locke, "o judiciário não era um poder separado, mas atributo geral do Estado", dessa forma, Locke não "considerava' o judiciário como um poder independente, não obstante ser a independência deste algo "essencial para o governo constitucional"; 2) Locke "cuida do funcionamento adequado e do exercício justos desses poderes, não por alguma doutrina de necessária separação, mas pelo conceito de "trust", que se aplica com sua força máxima ao legislativo, mas também ao executivo e ao federativo" (LASLETT, 2003: 276). Peter Laslett talvez esteja sendo severo na sua crítica. Não se descuida da importância do papel do judiciário, todavia Locke 'falava a seu tempo', talvez 'espelhando a constituição inglesa de sua época', mas Locke, a seu modo, bateu-se por um 'poder partilhado', expondo os perigos do 'poder concentrado em uma única mão'. E, realmente o 'princípio da confiança' seria a diretriz de sua estruturação estatal, e por asseverar que a lei civil, baseada na lei de natureza, seria de caráter geral e impessoal: a mesma para ricos e pobres, não visualizou a possível relevância de um poder separado, com processos e procedimentos apartados na aplicação da lei.
} 
arbitragem que estes previram em seu legislativo para a solução de todas as diferenças que entre eles possam surgir [...]” (LOCKE, 2005, II, 212). Através do pacto, exclui-se o julgamento privado - "estranha doutrina" -, substituindo-o pelo juízo público - poder da comunidade -, sendo que legislador e juiz devem apresentar a característica principal e necessária da imparcialidade, problema um tanto quanto insolúvel da condição natural.

De fato, as reflexões sobre os inconvenientes do estado de natureza concluíam pela necessidade de um juiz imparcial, razão pela qual os homens teriam abandonado a condição natural. Todavia, a escolha lockiana de não estabelecer o poder judiciário, como poder fundamental da comunidade política, liga-se à sua opção pelo governo de leis e não de homens. Na medida em que as leis civis, baseadas nas leis de natureza, passam a ter eficácia, sua aplicação ao caso concreto não demandaria um poder em separado ${ }^{117}$.

Todavia, não obstante a ênfase dada ao "governo de leis", Locke concede que nem todos os casos podem ser previamente pautados pelas mesmas. Dessa forma, admite que o "bem da sociedade" pode exigir que "diversas questões sejam deixadas à discrição daquele que detenha o poder executivo". Há, aqui, uma certa discricionariedade para agir, como se depreende desta passagem do Segundo Tratado:

Pois não sendo os legisladores capazes de prever e providenciar, por meio das leis, tudo quanto possa ser proveitoso para a comunidade, o executor das leis, tendo nas mãos o poder, possui, pela lei comum de natureza, o direito de dele fazer uso para o bem da sociedade, nos muitos casos em que a lei municipal não fornece diretrizes, até que o legislativo possa ser devidamente reunido para deliberar sobre a questão (LOCKE, 2005, II, 159).

Locke permite, inclusive, o exercício de certa equidade: abrandamento do rigor da lei, por parte do governante, nos casos em que este entender ser mais adequado do que a aplicação da lei, e punição relativa. Logo, é "conveniente que o governante tenha o poder, em muitos casos, de atenuar a severidade da lei e perdoar alguns infratores", pois, uma vez que o fim do governo é "a conservação de todos tanto quanto possível, mesmo os culpados devem ser poupados sempre que não resulte daí nenhum prejuízo para os inocentes" (LOCKE, 2005, II, 159).

Nosso autor denomina de prerrogativa, esse "agir com certa discricionariedade" em prol do bem público, "sem a prescrição da lei e por vezes até contra ela" (LOCKE, 2005, II,

\footnotetext{
${ }^{117}$ Assim, o que se deve evidenciar na explanação lockiana sobre os poderes estatais é a sua preocupação em afastar as teses absolutistas do poder. Na esteira do jusnaturalismo, Locke advoga a ideia de que a autoridade política somente pode ser fundada em convenções - pactos consentidos. O governo tem sua conduta pautada na lei civil - baseada na lei natural -, logo, na consecução do bem público. Daí decorre a legitimidade da obediência civil.
} 
160). Chega a salientar que esse poder consiste em uma "prerrogativa acima de qualquer dúvida", não podendo ser questionado enquanto for utilizado para benefício da comunidade e em conformidade com os "encargos e fins do governo". Logo, deve ser legitimamente obedecido.

Locke procura sempre apresentar exemplos históricos que fundamentem suas ideias a respeito do poder e da comunidade política. E, no que toca à prerrogativa, explica que "na infância das sociedades políticas", com poucas leis estabelecidas, "o governo era quase todo prerrogativa", agindo o governante com discrição e zelo, para suprir lacunas legislativas, em prol da sociedade (LOCKE, 2005, II, 162).

Nessa linha, expõe que o exame da história da Inglaterra mostra que a prerrogativa “foi sempre maior nas mãos de nossos mais sábios e melhores príncipes", e o povo não contestava as ações do governante, porque "a tendência geral de suas ações era no sentido do bem público" (LOCKE, 2005, II, 165) ${ }^{118}$.

Atento, porém, a eventual uso indevido do poder-direito de prerrogativa, Locke levanta a questão: "quem há de ser o juiz do uso correto desse poder"? A sua resposta evidencia a soberania popular, ou seja, que o poder realmente supremo é o do povo:

entre um poder executivo em função com tal prerrogativa e um legislativo que dependa da vontade desse poder para sua reunião, não poder haver juiz sobre a Terra, assim como não pode haver nenhum entre o legislativo e o povo, caso o executivo ou o legislativo, quando em suas mãos tiverem o poder, pretendam ou se dediquem a escravizar ou destruir o povo. Nesses casos e em todos aqueles em que não há juiz sobre a Terra, não tem o povo outro remédio além do apelo aos céus (LOCKE, 2005, II, 168).

A prerrogativa não é poder arbitrário. Possui limites: cumprir a lei de natureza e promover "o bem público independentemente de regras" (LOCKE, 2005, II, 166) ${ }^{119}$. Caso isso não ocorra, surge o que Locke denomina de "usurpação do poder", ou seja, "atos que prejudiquem ou obstruam o bem público" (LOCKE, 2005, II, 163). Com efeito, Locke adverte sobre o uso da razão e do bom senso no que toca ao "poder discricionário" do governante,

\footnotetext{
118 Sempre a evidenciar a própria forma de governo inglesa, Locke exemplifica que o "poder de convocar o parlamento, quanto à ocasião, local e duração", certamente constitui uma prerrogativa do rei, "ditada pelo encargo de que seja usado para o bem da nação, conforme o requeiram as exigências dos tempos e a variedade de ocasiões" (LOCKE, 2005, II, 167).

${ }^{119}$ Locke, talvez sempre pensando na relação de confiança, afirma que é "possível e razoável que o povo não deva dedicar-se a fixar limites à prerrogativa de reis e governantes que não tenham transgredido os limites do bem público" (LOCKE, 2005, II, 166).
} 
proibindo o uso da prerrogativa para perpetuar desordens públicas, pois isto seria contrário ao ditame da lei de natureza, atraindo uma situação maléfica ao povo, provocando controvérsia e:

[...] por vezes, desordem públicas antes que o povo conseguisse recuperar seu direito original e fizesse com que se declarasse não ser prerrogativa aquilo que na verdade nunca fora. Porque é impossível que qualquer pessoa da sociedade venha alguma vez a obter o direito de causar dano ao povo [...] (LOCKE, 2005, II, 166).

Em tais situações, resta apenas o "apelo aos céus", precisamente, o direito que tem o povo de insurgir-se contra o governante (que provocou um estado de guerra), a fim de que se faça (ou volte a fazer) uso correto do poder confiado ao mesmo, para administrar a comunidade política. Sobre este direito natural, Locke adverte que:

[...] ninguém pense ver nesse direito o fundamento de uma desordem perpétua, pois ele opera, até que o inconveniente seja tão grande que a maioria o sinta e dele se canse, julgando necessário remediá-lo (LOCKE, 2005, II, 168).

O que Locke quer evidenciar é que o poder, em última instância, pertence ao povo e retorna ao povo, caso haja divergência entre o interesse público e o agir do governante.

A presente relação de insubordinação é perfeitamente explicável porque o governo é um "comissário". A relação entre os governados e o governo envolve uma relação de trust. A obediência civil advém da confiança de que este cumpra e fará cumprir a lei de natureza (na verdade, trará o cumprimento da lei de natureza que a complexidade das relações sociais e econômicas obstruiu) ${ }^{120}$.

Locke estabelece um governo de leis e vê a necessidade de uma certa separação de poderes, para melhor controlá-los. Afirma a necessidade de leis expressas e de um juiz, estabelecidos para evitar a incerteza no meio social. Traça parâmetros na elaboração da lei para evitar um poder arbitrário e absoluto, pois um governo sem leis estabelecidas e fixas não é compatível com os fins da sociedade.

\footnotetext{
${ }^{120}$ Segundo Locke, não está "em poder de homem algum submeter-se a outro homem de maneira a dar-lhe a liberdade de o destruir", porque Deus e a natureza jamais permitiriam "que um homem abandonasse a si mesmo a ponto de descuidar-se de sua própria preservação". Aqui, mais uma vez, o autor demonstra o limite do poder político: "e, já que não pode tirar a própria vida, tampouco pode dar a outro o poder de lha tirar" (LOCKE, 2005, II, 168). Sobre o tema, na observação de Paulo C Souza, para Locke, na medida em que o poder político se afaste de seus fins e o poder de prerrogativa deixe de atender ao objetivo de zelar pelo bem público, "cada indivíduo isoladamente ou em conjunto pode assumir o poder da prerrogativa estabelecida pelo direito à liberdade que possuem para a defesa do bem comum, em que o poder político tenha se omitido ou tergiversado [...]" (SOUZA, 2003, p. 122).
} 
No seu entender, o poder absoluto e arbitrário desarmaria a sociedade e armaria o Estado, tornando os membros da comunidade política presa fácil - condição pior do que o estado de natureza, no qual poderia se defender ${ }^{121}$. Ora, Locke nucleia a composição do poder político de modo a possibilitar a coexistência entre o exercício do governo (bem público) e o exercício das liberdades civis (particular).

O modelo lockiano de governo de leis proporciona um equilíbrio entre indivíduo e sociedade, entre governo e governados ${ }^{122}$. Pois o império da lei condiciona a liberdade, que passa a ter um sentido peculiar. A liberdade consiste na liberdade civil: da convivência social, da igualdade, da solidariedade, do repúdio ao autoritarismo. Validamente, consiste naquilo que se busca, contemporaneamente, na Commonwealth.

Locke esboça uma concepção quase que democrática: o legislativo é um poder delegado, voltado a determinados fins, razão pela qual o povo, objetivo último do governo, possui o direito/poder supremo de remover ou alterar o legislativo, caso este passe a deliberar de forma contrária à confiança nele depositada (LOCKE, 2005, II, 149). Eis o cerne de seu direito sagrado de insurreição, que será analisado a seguir.

\footnotetext{
${ }^{121}$ A estrutura organizacional da sociedade política - organização do poder civil -, como visto, destaca a preocupação lockiana em evitar a concentração do poder, sustentando a separação entre o legislativo e o executivo. Todavia, estabelece a subordinação do executivo ao legislativo, e este, por sua vez, subordina-se ao povo, que detém o poder originário.

${ }^{122}$ Nesse particular, deve ter em mente que o pacto a fundar a sociedade civil e o governo possui como traço principal o elemento confiança. Assim, uma vez quebrada a confiança, caso haja violação dos direitos inalienáveis, do bem-estar geral, os membros têm o direito e o dever de questionar a conduta do governo ou de quem exerça a autoridade política confiada, como se verá à frente.
} 


\section{Capitulo III - Poder, Direitos e Deveres: o matiz da obediência e da resistência}

A preocupação com a definição e a legitimidade do poder político levou Locke a distinguir espécies de poderes que envolvem as relações entres os homens em um capítulo à parte no Segundo Tratado, precisamente, o Capítulo XV, intitulado: "Dos poderes paterno, político e despótico considerados em conjunto”.

O seu desvelo com a distinção entre o poder paterno e o poder político decorre de sua luta contra as concepções paternalistas do poder. Para Locke, o poder paterno é uma decorrência natural do dever de zelo dos pais, que devem governar a prole até que atinjam a maioridade, "até chegarem ao uso da razão", ou a um estágio de conhecimento "em que se possa supor conhecerem a lei", seja esta a lei de natureza ou a lei civil, "pela qual terão de governar a si mesmo" (LOCKE, 2005, II, 170).

O poder paterno "não contém nenhuma parte ou grau do tipo de domínio que um príncipe ou magistrado tem sobre seus súditos" (LOCKE, 2005, II, 71). A sociedade conjugal ou a entre pais e filhos não podem ser chamadas de sociedade política, pois a autoridade marital em dados casos, ou mesmo o poder paterno, que pode ser considerado um "governo natural", não se estende "aos fins e à jurisdição daquele que é político" (LOCKE, 2005, II, 170).

$\mathrm{O}$ autor procurou com os seguintes argumentos estabelecer as profundas diferenças entre esses três tipos de poderes e de obediência:

o poder paterno está aquém do poder do magistrado na mesma medida em que o poder despótico está além; e que o domínio absoluto, onde quer que esteja situado, está tão longe de ser uma espécie de sociedade civil que é incompatível com ela, na mesma medida em que a escravidão o é com a propriedade. O poder paterno existe apenas enquanto a menoridade torna o filho incapaz de gerir sua propriedade; o político, quando os homens têm a propriedade à sua disposição; e o despótico, sobre aqueles que não possuem propriedade alguma (LOCKE, 2005, II, 174).

O fundamento da relação entre pais e filhos decorre da própria natureza, é ela quem confere o pátrio poder aos pais. Já o poder político advém do acordo voluntário, no qual os governados aquiescem em conceder o poder ao governante para determinados fins. O poder despótico tem sua origem no confisco, ou seja, age pela força, e não pelo direito, subjuga os governados ao arbítrio do soberano. 
Locke descreve três tipos de sociedade, nas quais os homens podem interagir e exercitar as relações de poder: a conjugal, a entre pais e filhos e a entre servos e senhor (LOCKE, 2005, II, 77-86) - diferenciando-as da sociedade civil (LOCKE, 2005, II, 87-94). Procura evidenciar que são três diferentes formas de autoridade e de obrigações que resultam em dever de obediência, almejando diferenciá-las da obediência civil. Nesta explanação, ressalta o caráter moral das obrigações a que os homens assumem ou podem vir a assumir.

Da mesma forma, o autor destaca a diferenciação entre o poder político e o poder despótico, enfatizando que a legitimidade do poder político está no consentimento, ou seja, a legitimidade da obrigação - dever de obediência - entre governado e governante decorre de um pacto - acordo voluntário.

O poder despótico, por sua vez, decorre da força, originando uma relação equivalente à de senhor e escravo, sem qualquer legitimidade; por isso os súditos não estão obrigados a obedecer:

todo aquele que alcança o exercício de qualquer parte do poder por qualquer meio que não o prescrito pelas leis da comunidade não tem direito a ser obedecido, mesmo que a forma da sociedade política seja conservada - já que não se trata da pessoa que as leis designaram e, consequentemente, não é a pessoa a quem o povo consentiu (LOCKE, 2005, II, 198).

Locke não teme a autoridade ou o poder em si, uma vez que seu governo é um governo de leis e não de homens. O poder legítimo, isto é, o poder civil é o que decorre do consentimento dos que estão sujeitos à obediência. Conclui-se que a obediência é consequência da confiança depositada no governante e que o governado não pode subtrair-se a esse dever, pois

cada pessoa ficou sujeita, igualmente com os homens de mais baixa condição, a essas leis que ela mesma, como parte do legislativo, estabelecera; não poderia qualquer pessoa, por sua própria autoridade, evitar a força da lei uma vez promulgada nem, por qualquer alegação de superioridade, pleitear isenção, para com isso sancionar seus próprios desvios ou os de seus dependentes. Nenhum homem, na sociedade civil, pode estar isento de suas leis (LOCKE, 2005, II, 94).

Locke não poupou esforços, no iter de seu Segundo Tratado, para enfatizar o objetivo e os limites do poder político, como condição única para se exigir a obediência dos súditos:

sendo o fim e a medida desse poder, quando nas mãos de todos os homens no estado de natureza, a conservação de toda a sua sociedade, isto é, da humanidade em geral, ele não poder ter outro fim ou medida, quando estiver nas mãos do magistrado, que o de conservar os membros dessa sociedade em 
suas vidas, liberdades e posses. E, portanto, não pode ser um poder arbitrário e absoluto sobre suas vidas e haveres [...] (LOCKE, 2005, II, 171) ${ }^{123}$.

O exercício da autoridade ocorre nos termos da lei e em prol da comunidade. Caso o governo se afaste de suas finalidades, agindo com parcialidade, à margem da lei e contra os interesses dos governados e da própria comunidade política, vem a trair a confiança depositada, destruindo sua própria autoridade, pois

exceder os limites da autoridade não é mais direito no grande que no pequeno funcionário; não é mais justificável num rei que num guarda. Mas é sempre pior naquele, pois é maior a confiança nele depositada e já tem ele parte muito superior a do resto de seus semelhantes, e supõe-se que, dadas as vantagens de sua educação, função e conselheiros, tenha mais discernimento para julgar o certo e errado (II, 202).

Assim, Locke procura estabelecer diferenças entre o poder legítimo e o poder despótico e tirânico, para ter parâmetros para que o Corpo do Povo possa aferir e julgar se o exercício do poder está ou não em conformidade com os fins a que foram estabelecidos. $\mathrm{O}$ Segundo Tratado sobre o Governo tem como foco principal a preocupação em balizar o direito de resistência e demonstrar os parâmetros para se identificar uma autoridade política ilegal e ilegítima.

Locke não faz, aqui, uma apologia à rebelião ou revolução infundada. Ao contrário, procura distinguir as situações que ensejam o "apelo aos céus", situações que tornam legítima a desobediência civil, pois são situações que causam a degeneração do governo civil, liberando o súdito do dever de obediência, como a seguir se expõe $\mathrm{e}^{124}$.

\footnotetext{
${ }^{123} \mathrm{Na}$ articulação de seu pensamento sobre a legitimidade da autoridade civil, por várias vezes, Locke retoma o conceito e as características do poder político, para bem distingui-lo de eventuais tendências absolutistas. $\mathrm{O}$ poder despótico é apresentado como o poder absoluto que se possa ter sobre outrem, inclusive para tirar-lhe a vida, se assim entender. Tal disposição de poder é uma afronta à lei de natureza, sendo um poder "que nem a natureza concede", pois que esta não faz e nem autoriza "distinções entre um homem e outro, nem pode um pacto conferir, pois, não tendo o homem um tal poder arbitrário sobre sua própria vida, não pode dar a outrem um tal poder sobre ela" (LOCKE, 2005, II, 172). A descrição do poder despótico já ressalta que este não é um poder natural - tal poder a natureza não concede -, até porque ninguém tem poder arbitrário sobre a própria vida, pois somos criaturas de Deus e somente este pode nos tirar a vida. Locke não reconhece o poder despótico - o Estado despótico - como uma sociedade civil, pois carece de legitimidade - consentimento do povo.

${ }^{124} \mathrm{O}$ agir claramente ameaçador do soberano, descumprindo os fins a que está obrigado, implica na quebra da confiança depositada e a perda da autoridade deste, que se tornou ilegítima, autorizando, o direito de resistência por parte dos detentores do poder originário: o povo. Instala-se uma situação de crise na relação entre governo e governados, relativizando o dever de obediência, uma vez que tais situações remetem os homens ao que Locke denomina de "apelo aos céus": quando não se pode mais apelar à justiça terrena, na medida em que os próprios poderes (magistrados, legislativo ou o próprio governo) se tornam injustos e ilegítimos (LOCKE, 2005, II, 176). O "apelo aos céus", como na passagem bíblica aludida por Locke (Jefté: Juízes II, 27), reaviva o direito de autodefesa, possibilitando resistir ao poder despótico pela quebra da confiança outrora depositada na autoridade escolhida.
} 


\subsection{Dos governos ilegítimos}

No Segundo Tratado, Locke tece considerações sobre a degeneração do governo, que o torna ilegítimo, desobrigando o súdito da obediência civil. E por fim, no capítulo XIX, estabelece uma suma das causas geradoras da dissolução do governo, apresentando uma proposta da condição de legitimidade da resistência à autoridade política - da justificável desobediência civil. As causas que ensejam a degeneração do governo são: a conquista, a usurpação, a tirania e, por fim, a dissolução do governo.

A conquista ocorre em decorrência de uma invasão de força externa, o que leva à dissolução da própria sociedade (da união dos homens), que não será capaz de se manter ou de se sustentar como um corpo inteiro e independente, e consequentemente à dissolução do governo. Para Locke, os antigos integrantes da sociedade invadida retornam ao estado em que se encontravam, retomando a liberdade de agir "por conta própria", podendo "prover a própria liberdade", conforme lhe for conveniente, em qualquer outra sociedade (LOCKE, 2005, II, 211). A invasão externa não tem legitimidade para dar origem a um novo governo, o conquistador não pode exigir a obediência do conquistado.

O intento de Locke, ao abordar a conquista, é desfazer a confusão daqueles que equiparam a "força da arma" ao consentimento do povo ${ }^{125}$. A conquista jamais poderá ser uma das origens do governo, uma vez que sem a necessária e voluntária aquiescência de cada um dos homens livres e iguais que se organizam - do povo --, nunca se poderá fundar uma sociedade política (LOCKE, 2005, II, 175). A força da arma - a guerra -- destrói o vital elemento da confiança entre os homens.

Locke estabelece uma distinção entre guerra justa e injusta, embora em qualquer caso designe o poder "conquistador" de despótico. Nosso autor compara a "conquista injusta" com a invasão de residências por ladrões que forçam, com atos de violência, a submissão da vítima, para tomar a sua propriedade (LOCKE, 2005, II, 176). Destarte, o conquistador não

\footnotetext{
${ }^{125}$ Nesta passagem Locke menciona o seu famoso "apelo aos céus", de forma a registrar a indignação ativa contra injustiças, o direito de autodefesa e a retomada do direito executivo da lei de natureza. O governo ilegítimo-injusto, segundo Locke, age tal qual um ladrão "que invade a sua casa", pois a "injúria e o crime são iguais, sejam cometidos por quem porta uma coroa ou por um vilão desprezível". Para Locke a "única diferença é que os grandes ladrões punem os pequenos para mantê-los em obediência", e os primeiros "são grandes demais para as débeis mãos da justiça deste mundo, e têm em suas próprias mãos o poder de punir os ofensores" (LOCKE, 2005, II, 176). Assim, no caso do ladrão, pode-se apelar à lei, à justiça; mas, nas situações em que o "ladrão" é o próprio poder, ou seja, quando é a própria autoridade quem comete a injustiça, a quem se deverá apelar? A única saída vem a ser a resistência, pois o conquistador não tem "nenhum direito à sujeição e obediência dos conquistados" (LOCKE, 2005, II, 176).
} 
tem o consentimento do conquistado na sua pretensão de um novo governo e, por isso, não pode pretender qualquer direito à submissão do conquistado ${ }^{126}$. Logo, não tem o direito de reivindicar a obediência dos conquistados, assim como não se deve obediência a ladrões, salteadores ou piratas.

Da mesma forma, na guerra justa, nas ocasiões em que se pode perceber uma contenda legítima, o poder do conquistador também é considerado despótico e o conquistado não está obrigado a qualquer sujeição. Caso o primitivo governo seja dissolvido, o povo tem a liberdade para iniciar um novo governo, de acordo com suas próprias regras (LOCKE, 2005, II, 185). Assim, ainda que a vitória venha a favorecer o lado justo, o conquistador na guerra justa "não obtém poder algum sobre aqueles que conquistaram" (LOCKE, 2005, II, 177) ${ }^{127}$.

A usurpação, por seu turno, é uma espécie de conquista interna do poder, também reputada de injusta por Locke, uma vez que se dá à revelia dos súditos. A usurpação pode ocorrer nas ocasiões em que o executivo toma para si a atividade do legislativo. $\mathrm{O}$ usurpador não tem nenhum direito a seu favor, pois entra na posse daquilo a que tem direito um terceiro, indo além do que foi originariamente estabelecido como forma e regra do governo.

Cabe ao povo estabelecer as pessoas com os encargos a serem exercidos, e aquele que vier a exercer o poder por meios diferentes do prescrito pelas leis da comunidade não tem nenhum direito a ser obedecido. O usurpador não é a pessoa que a lei indica para exercer determinado encargo e, portanto não tem a principal característica a legitimar a autoridade: o assentimento do povo. Observa-se que Locke permite um consentimento posterior, ao estabelecer que o povo tem a liberdade para dar o seu consentimento, podendo conceder e confirmar o poder que era fruto de usurpação, tornando-o legítimo (LOCKE, 2005, II, 198).

Outra forma de exercício ilegítimo do poder, segundo Locke, é a tirania. O governante, utilizando o poder para além dos limites estabelecidos para o exercício do

\footnotetext{
${ }^{126}$ Para Locke, guerra injusta ocorre quando o agressor, voluntariamente, põe-se em estado de guerra com outrem, sem qualquer motivo que eventualmente autorizasse uma contenda, violando injustamente o direito alheio (LOCKE, 2005, II, 176). A guerra justa equivale à posição de defesa, o ato de repelir ataques injustos (LOCKE, 2005, II, 178).

${ }^{127}$ Locke estabelece varias restrições sobre o possível domínio - poder despótico - do conquistador, inclusive de caráter patrimonial, limitando este poder absoluto apenas sobre a vida e não sobre o patrimônio do conquistado, exceto nos casos em que se reconhece uma compensação de danos causados pela guerra, que não poderá atingir bens dos filhos ou esposas dos conquistados que participaram da guerra (LOCKE, 2005, II, 182-183). Locke afirma que, ainda que se trate de guerra justa, se o conquistador e os conquistados não formarem um governo único, o vencedor "justo" tem "poder absoluto sobre a vida daqueles que, por lhe travarem uma guerra injusta, perderam o direito a ela", todavia, por ser o seu poder "puramente despótico" não pode exercê-lo "sobre a vida ou a fortuna daqueles que não se envolveram na guerra e nem mesmo sobre as posses daqueles que de fato se envolveram nela" (LOCKE, 2005, II, 178). Locke, aqui, quer deixar a salvo a população civil e as posses das pessoas como um todo.
} 
encargo que lhe foi designado, torna-se tirânico. Embora autorizado, usa a autoridade conferida não para o bem dos súditos, mas, ao contrário, buscando vantagem própria, divorciando-se dos ditames da lei, deixando-se levar por ambição, caprichos, vingança ou outra paixão menos nobre (LOCKE, 2005, II, 199).

De acordo com Locke, o governante, no seu mister, compromete-se a seguir a lei e proteger o povo. Assim, a distinção entre o rei e o tirano é que o primeiro pauta o seu poder pela lei e em prol do bem público, enquanto o segundo "faz que tudo ceda à sua própria vontade e apetite" (LOCKE, 2005, II, 200). Numa palavra, "Onde termina a lei, começa a tirania" (LOCKE, 2005, II, 202).

É neste momento que Locke indaga se seria possível opor-se às ordens de um governante: "Podem, então, ser contrariadas as ordens de um príncipe? Será possível resistir a ele tantas vezes quantas alguém se julgue agravado e imagine não ser direito o que esse lhe faz?” (LOCKE, 2005, II, 203). Sua resposta é eloqüente:

A isso respondo que a força não se deve opor a coisa alguma, além da força
injusta e ilegítima; quem quer que faça qualquer oposição em qualquer outro
caso chama a si uma justa condenação, tanto de Deus como do homem.
Assim, não resultará nenhum perigo ou confusão, tal como se alega com
freqüência [...] (LOCKE, 2005, II, 204).

Os argumentos que sustentam esta resposta são decisivos para a análise de sua teoria da desobediência, caracterizando como legítima a resistência ao tirano. Segundo Locke, não há como impedir a resistência por parte do povo à força ilegal usada contra ele (LOCKE, 2005, II, 209), pois aquele que excede, com sua autoridade, o poder que foi conferido pela lei, fazendo uso da força que possui sob seu comando para fazer o que a lei não permite, deixa, por isso, de ser magistrado, e como delibera sem autoridade, justifica a oposição que se lhe faça, assim como nos opomos a qualquer pessoa que viole com a força o direito alheio (LOCKE, 2005, II, 202).

Locke sustenta sua teoria da resistência abordando a dissolução do governo e mencionando uma forma peculiar de tirania, ou seja, uma "dissolução interna que, como a da tirania, atinge não toda a sociedade, mas somente o poder constituído; em outras palavras, não libera os cidadãos do contrato social, limitando-se a anular a confiança nos governantes" (BOBBIO, 1997, p. 242).

Nesta forma de degeneração do poder, Locke apresenta duas condições que ensejam a dissolução do governo: 
- A alteração do poder legislativo, nas situações em que o executivo se arvora na prerrogativa deste, substituindo-o no seu mister. Nesta hipótese, Locke distingue cinco situações: 1) o príncipe impõe sua própria vontade arbitrária em lugar das leis, que representam a vontade do povo (LOCKE, 2005, II, 214); 2) criam-se empecilhos para a reunião do legislativo (LOCKE, 2005, II, 215); 3) modificações arbitrárias em relação à forma de eleição, seja em relação ao corpo do eleitorado ou ao procedimento eleitoral (LOCKE, 2005, II, 216); 4) por ato do príncipe ou do legislativo, o povo é entregue à sujeição de poder estrangeiro (LOCKE, 2005, II, 217); e 5) aquele que detém o poder executivo vem a negligenciar ou abandonar seu cargo, prejudicando ou deixando de aplicar as leis aprovadas pelo legislativo (LOCKE, 2005, II, 219) ${ }^{128}$.

- O poder legislativo, em desrespeito aos limites que lhe são impostos, passa a agir contra os direitos naturais dos súditos, "tenta violar a sua propriedade", agindo de forma arbitrária em relação à "vida, liberdade ou bens do povo" (LOCKE, 2005, II, 221). O legislativo age contra o encargo que lhe foi confiado - proteção das propriedades, razão de terem entrado "em sociedade e em nome de que o povo se submete aos legisladores por ele instituídos" (LOCKE, 2005, II, 222). Da mesma forma, age contra o encargo a ele confiado quando empregam a força, o tesouro ou cargos da sociedade, visando corromper os representantes "e conquistá-los para seus propósitos", ou, abertamente, “empenha de antemão os eleitores", prescrevendo à escolha deles "alguém a quem, por meio de solicitações, ameaças, promessas ou de outro modo, conquistou para seus próprios desígnios, e os emprega para eleger os que tenham prometido de antemão em que votar e o que decretar" (LOCKE, 2005, II, 222) $)^{129}$.

No primeiro caso, as prerrogativas do legislativo são violadas pelo executivo e, no segundo, o próprio legislativo é que não se atém às suas atribuições, e agindo ilicitamente, causa prejuízo à comunidade. Nestes casos, o povo fica livre para instituir novo governo, pois

\footnotetext{
${ }^{128}$ Para Locke, a execução das leis é a própria estruturação da sociedade, mantendo cada parte do corpo político “em seu devido lugar e em sua devida função, quando isso cessa por inteiro, o governo visivelmente cessa e o povo torna-se uma multidão confusa, destituída de ordem e conexão (LOCKE, 2005, II, 219).

${ }^{129}$ Aqui, Locke tece severa crítica aos que elegem sem ponderações, não decidem livremente, bem como aos que se deixam eleger sem terem sido livremente escolhidos. As assembleias "preparadas" ou votos (viciados) dados sem debates ou exame necessário agem contrariamente à instituição da sociedade, traindo o maior de todos os bens: a liberdade (LOCKE, 2005, II, 222).
} 
o poder retorna ao povo, que tem o direito de reaver sua liberdade original e instituir novo legislativo (LOCKE, 2005, II, 220).

Locke dedica uma considerável análise sobre esta forma de degeneração do poder, pois, a seu ver, a única forma de governo civil possível é aquela estruturada com base na separação entre os poderes executivo e legislativo, com a subordinação do executivo ao legislativo. Qualquer alteração nesta estrutura retira a legitimidade do governo, autorizando a resistência do povo ${ }^{130}$.

Sobre as causas que tornam ilegítimo um governo, Locke distingue a dissolução do governo e a dissolução da sociedade política. Segundo explica, seria difícil e raro a dissolução da sociedade política, que poderia ocorrer em casos de invasão de força estranha, como no caso de conquista externa (LOCKE, 2005, II, 211). Nesta hipótese, como já analisado, cada um retorna ao seu estado anterior - estado de natureza - estando livre para participar de qualquer outra sociedade.

O raciocínio lockiano se encaminha para declarar que o povo torna-se uma multidão "vencida e dispersa da proteção e da dependência da sociedade que a deveria ter protegido contra a violência" (LOCKE, 2005, II, 211). Ora, a finalidade da sociedade política é a proteção que não foi garantida. Ausente esta proteção, libera-se "cada homem" a procurar o melhor para si, para prover a sua segurança.

Assim, sempre que a sociedade civil se dissolve, o governo consequentemente se dissolverá, pois a espada do conquistador corta o governo pela raiz, desfazendo em pedaços a sociedade, fragmentando e subjugando a comunidade, que perde sua força ante o ato de violência (LOCKE, 2005, II, 211).

Nesse particular, Locke pondera que não seriam necessários muitos argumentos para demonstrar que o governo não pode subsistir, pois "isso é tão impossível quanto a estrutura de uma casa subsistir quando seus materiais são espalhados ou dissipados por um turbilhão, ou transformados num confuso amontoado por um terreno" (LOCKE, 2005, II, 211).

\footnotetext{
${ }^{130} \mathrm{O}$ repúdio ao poder absoluto é marca indelével no pensamento lockiano, posto carecer de legitimidade, sendo um atentado contra as propriedades do ser humano (vida, liberdade, igualdade e outras posses). A resistência não é desordem, não é um ato irracional contra o governo, ao contrário, é um ato racional contra um poder ilegítimo. Longe está de se tratar de uma doutrina sediciosa ou irresponsável, pois Locke procura delinear o que se deve entender por autoridade despótica. Da mesma forma, o próprio exercício deste "apelo defendido" possui características próprias, distanciando-se de uma rebelião insana ou estímulo à anarquia. Ao contrário, as últimas passagens do Segundo Tratado dão conta da extrema responsabilidade do que seja resistir ou evitar um poder ilegítimo, para que se possa fazer valer o necessário respeito à lei de natureza que determina a autopreservação e a preservação da humanidade.
} 
Por outro lado, no que toca à dissolução do governo, a recíproca não é verdadeira, ou seja, a decomposição ou extinção do governo não acarreta a dissolução da sociedade, porque o pacto de sociedade permanece, e o poder ainda continua com e na sociedade. Nesta hipótese, o povo, propriamente soberano, fica livre para instituir um novo governo, conforme lhe for mais conveniente.

Ora, a "sociedade não pode jamais, por culpa de terceiro, perder o direito natural e original de preservar-se, o que só pode ser feito por um legislativo estabelecido e uma execução justa e imparcial das leis elaboradas" (LOCKE, 2005, II, 220). O poder que cada indivíduo depositou na sociedade ao dar seu consentimento, nela ingressando, não pode retornar novamente aos indivíduos enquanto durar a sociedade, ficando sempre na comunidade (LOCKE, 2005, II, 243).

Tem-se aqui uma condição relevante para a existência da comunidade política, pois do contrário ela deixaria de existir, uma vez que não há como pensar em uma sociedade ou comunidade política com todos os indivíduos que a formam com seu poder originário inerente ao estado de natureza. Isso seria contrário ao pacto original, porque cada homem conservaria o poder executivo da lei de natureza.

No entanto, apesar da regra de que somente o legislativo - porta voz do povo - ou o governante (rei e/ou magistrado - poder executivo) podem provocar mudanças na comunidade política, cuidando para que não se instale um mal generalizado ao povo e, não havendo outro remédio, Locke concede, então, a possibilidade de resistência ao soberano. Seus argumentos giram em torno do direito de liberdade e do dever de obediência, merecedores de uma melhor análise, como se propõe a seguir. 


\subsection{Confiança e resistência: confluência liberdade e obediência}

Para Locke, atentar contra o ser humano nas suas posses materiais e imateriais é um crime contra a humanidade. Quem age desta forma agride a lei de natureza que determina a assistência mútua, colocando-se em estado de guerra e podendo ser punido. Ademais, em se tratando daquele a quem se confiou o poder político - o governo -, o seu ato é reputado como de traição capital, pois, ao violar a lei, o seu delito é "maior, tanto por ser uma ingratidão pela maior parte que pela lei" lhe cabe, "como por ser também um abuso do encargo" a ele “confiado por seus semelhantes" (LOCKE, 2005, II, 231).

Ora, os homens não deixaram o estado de natureza, renunciando ao poder executivo da lei de natureza e à sua liberdade e igualdade naturais, para serem subjugados, injustiçados ou oprimidos por um poder despótico. Esta é a base do direito de resistência, pois:

De uma coisa, porém, estou certo: todo aquele que, governante ou súdito, pela força empreende invadir os direitos do príncipe ou do povo e lança as bases para a derrubada da constituição e da estrutura de qualquer governo justo, é culpado do maior crime, penso eu, que um homem é capaz de cometer, devendo responder por todos os malefícios de sangue, rapinagem e desolação que o desmoronamento de um governo traz a um país. E aquele que o faz deve com justiça ser considerado inimigo comum e praga da humanidade, devendo ser tratado como tal (LOCKE, 2005, II, 230) ${ }^{131}$.

Locke faz uma advertência para os reflexos do ato transgressor do soberano, considerando-o passível de resistência por parte do povo, na medida em que ocasione malefícios generalizados, com indícios claros da má intenção do governante em perpetrar e perpetuar-se na prática de atos injustos e opressores. Segundo Locke:

enquanto o malefício não estiver generalizado e os maus propósitos dos governantes não se tornarem manifestos ou perceptíveis para a maior parte, é

\footnotetext{
${ }^{131}$ A resistência lockiana não é novidade no contexto histórico-político do século XVII. Como observa Alberto Ribeiro de Barros, o século XVI "antecipou esse debate", no qual "teólogos luteranos começaram a reconhecer a possibilidade de rebelião" ao poder secular, sendo possível "desobedecer as ordens dos governantes que fossem contrárias aos mandamentos de Deus". Nesta linha, o inicial conflito religioso entre católicos e protestantes, sobre a resistência ao poder político, passa a assumir contornos laicizados. Sobre o tema, entre outros, lembra a reflexão de Theodore de Bèze, que articula suas ideias sobre o direito de resistência em função da "origem contratual do poder político". Dessa forma, "a origem da submissão política, segundo Bèze, estaria nesse ato de livre consentimento por parte do povo, que promete obediência ao príncipe, desde que ele respeite as leis divinas e as leis fundamentais. Se o príncipe ordenar coisas contrárias a essas leis, seus súditos passam a estar livres da obrigação de obedecer, seja em nome de uma consciência religiosa, seja em nome de um direito público" (BARROS, 2006, p. 4). Na mesma linha, Locke apresenta a origem contratual do poder político e o seu direito de resistência frente aos governos que perdem legitimidade de sua autoridade por descumprirem os mandamentos da lei de natureza, quebrando o elo de confiança necessário entre governo e governados.
} 
pouco provável que o povo, mais disposto a sofrer do que a corrigir os agravos pela resistência, comece a agitar-se (LOCKE, 2005, II, 230) ${ }^{132}$.

Nosso autor trabalha com a aferição de malefício de forma peculiar; não é qualquer ato do governante que está sujeito à resistência do povo, com a consequente retomada do poder. A sua preocupação com a paz da humanidade é maior, o que, de certa forma, pode obrigar os governados a sofrerem algumas injustiças - dever de resignação, sempre, é claro, com a opção individual de reclamar ao judiciário - magistrado. Do contrário, não faria sentido a fala lockiana sobre a liberdade e igualdade que a lei civil resgataria na comunidade política.

Locke estava atento às possíveis críticas ao seu direito de resistência e aos limites que estabelece para a exigência da obediência civil. Apresenta assim, uma justificativa responsável para a desobediência, com regras bem definidas, longe de se constituir um estímulo a atos anárquicos.

A sua tese de que a obediência poderia se transformar na mais legítima desobediência, frente ao poder despótico, tem respaldo nos seus argumentos sobre a liberdade e a igualdade de todos. Tais características, inerentes ao homem, em última instância, devem levar ao respeito mútuo e à confiança entre todos, nas suas relações privadas ou públicas, ou seja, ao trust lockiano implícito nas relações dos governados entre si e entre governantes e governados.

Locke, como visto, define as situações em que se pode reputar um poder como despótico, delimita as situações em que se considera o poder como ilegítimo (degenerado) a ensejar a desobediência. Em seguida, mostra uma espécie de iter ou procedimento para a possível rebelião, as regras pelas quais o povo exerce o seu direito sagrado de se esquivar, legitimamente, da obediência ao soberano.

O Capítulo XIX do Segundo Tratado evidencia que o direito de resistência é o último recurso - remédio - a ser utilizado. O seu exercício é autorizado quando não se possa buscar proteção na própria lei, quando não houver a quem apelar ante uma grave injustiça, pois:

\footnotetext{
${ }^{132}$ Não é qualquer desgoverno que incita a resistência do povo. Locke defende uma certa tolerância em relação ao detentor do poder, mas isso deve ser entendido sob o prisma de irregularidades pontuais e o súdito conta com a lei (magistrado) a quem apelar. Isso se percebe pela sua explanação lembrando Ulisses e o "Covil de Polifemo", refletindo em que medida o homem honesto e inocente "deve ceder em silêncio tudo quanto possui em nome da paz" e que "tipo de paz seria esta num mundo de violência e rapinagem". O "Covil de Polifemo" é usado como exemplo deste tipo de paz e governo, no qual "Ulisses e seus companheiros não tinham alternativa a não ser submeterem-se pacificamente a serem devorados" por quem "tinha poder sobre eles" (LOCKE, 2005, II, 228). Percebe-se que, segundo Locke, somente quando a situação se torna intolerável o povo, conscientemente, poderá e deverá usar o seu direito de autodefesa. A questão que surge aqui, e que mais à frente Locke procurará resolver, é a de que, tal qual Ulisses, alguém deverá julgar quando e como agir para a resistência - desobediência - ao soberano.
} 
quando a parte que sofreu a injúria puder ser compensada e seus prejuízos reparados mediante o apelo à lei, não haverá pretexto para a força, que só deve ser usada quando alguém for impedido de recorrer à lei. Pois nenhuma força deverá ser considerada hostil, a menos que não permita o remédio de tal apelo. E é apenas essa força que põe quem a usa em estado de guerra e torna legítimo resistir-lhe [...] (LOCKE, 2005, II, 207).

O exercício de um poder despótico, o mau governo, leva ao estado de guerra, uma vez que quem usa a força sem direito ou deixa de lado a lei torna-se uma autoridade arbitrária. Isso implica perder a legitimidade, face ao descompasso com a lei de natureza, que determina a preservação e o respeito mútuos. Este agir invalida os vínculos existentes e todos passam a ter o direito de se defender e de resistir ao agressor que se colocou em estado de guerra em relação à própria comunidade (LOCKE, 2005, II, 232).

O direito de preservação mostra que o poder despótico - o governo degenerado equipara-se ao estado de guerra, devolvendo o direito de executoriedade a cada um dos homens integrantes do pacto, pois não ter a quem apelar significa que o apelo será aos céus, o que coloca cada homem como juiz de si mesmo:

pois quando não houver judicatura sobre a terra para decidir as controvérsias entre os homens, Deus no céu será o juiz. Só Ele, é verdade, é juiz do que é direito. Mas todo homem é juiz por si próprio, em todos os demais casos assim como neste, para decidir se outro se pôs em estado de guerra com ele e se deve apelar ao juiz supremo, tal como fez Jefte (LOCKE, 2005, II, 241).

A expressão "ser juiz de si mesmo" poderia trazer a seguinte dúvida:

- a traição da confiança por parte do governo atrai o estado de guerra, sendo legítimo ao homem usar o seu direito individual de preservação - autodefesa particular?

- A rebelião não acarretaria o retorno ao estado natural, desaparecendo a sociedade civil pelo direito de resistência?

Afinal, o direito de resistência permite destruir o soberano ou os membros do legislativo que se tornaram uma clara ameaça aos direitos dos súditos e da sociedade (LOCKE, 2005, II, 230).

De fato se instala uma crise, pois, se o poder comum se corrompe, não há a quem apelar, aparentemente cada um se torna juiz em causa própria. Todavia, como já assinalado, Locke atribui conotação política ao direito de resistência, ou seja, não é uma resistência 
individual (mera vingança), é civil, envolvendo uma decisão da comunidade civil, sendo o “corpo do povo o árbitro" - o povo é o juiz dessa crise (LOCKE, 2005, II, 242).

A comunidade política possui autoridade para usar a força, mas somente está autorizada a agir desta forma em benefício do bem comum e, sobretudo, desde que autorizada diretamente ou indiretamente pela própria sociedade. Por ser este o último recurso a ser utilizado e em função da possibilidade de ocasionar uma certa crise à comunidade política, o povo é o único que poderá julgar a fidelidade do governo, e se este está ou não divorciado de sua finalidade.

$\mathrm{O}$ ato de julgar a situação de crise que se instala é algo delicado, pois traz a instabilidade que Locke procurou resolver com o estabelecimento do governo. Locke, desta forma, fixou parâmetros para aferir a "dissolução do governo" e estabeleceu que somente o povo poderá julgar a controvérsia entre súdito e soberano.

Este é um ponto relevante na doutrina lockiana, que a deixa longe de eventuais ressonâncias individualistas. Com efeito, ainda que o argumento desta insurreição seja o fato de que os homens possuem direitos naturais anteriores ao estabelecimento da sociedade política e, esta exista para protegê-los, caso a autoridade política afaste-se de suas finalidades, é o povo, e não o individuo isoladamente, que tem legitimidade para aferir a legalidade ou não da conduta do governante.

Nas palavras de Peter Laslett:

[...] somente o povo pode decidir se ou quando seus governantes agiram contrariamente à confiança neles depositada ou se o legislativo mudou seu modo de proceder, e somente o povo, como um todo, pode agir como árbitro em qualquer disputa entre os governantes e uma parte de seu corpo. Se os governantes resistirem a tal julgamento, ou agirem de qualquer forma que ameace fazer com que o povo cesse de ser uma comunidade e se torne uma multidão confusa, então teremos um estado de natureza com todas as suas desvantagens (LASLLET, 2003, p. 264).

Locke esposa uma espécie de decisão popular democrática, proclamando que somente o povo poderá julgar se o príncipe e/ou o legislativo estão agindo contrariamente ao encargo que lhes foi confiado. Para ele, somente o povo pode ser juiz, porque:

quem mais poderá julgar se tal depositário ou deputado age corretamente e segundo o encargo a ele confiado, senão aquele que os designou e que deve, por esse motivo, conservar o poder de afastá-los quando falharem em seu encargo? Se tal é razoável nos casos particulares de homens particulares, por que deveria ser diferente naqueles de maior importância, em que o bem de 
milhões está em jogo e também onde o mal, se não for evitado, é maior e a reparação muito difícil, custosa e arriscada? (LOCKE, 2005, II, 240).

Nesta passagem, Locke dissipa as eventuais controvérsias a respeito de que o direito de resistência, com o retorno do poder ao povo, instalaria o estado de guerra, voltando cada homem ao estado de natureza. Nosso autor se refere ao povo como juiz - ao conjunto de homens organizados que, não obstante uma crise política, busca manter o pacto, o estado civil.

$\mathrm{O}$ ato de resistência assume perfil de ato político impondo a submissão de todos à vontade do corpo político, relativamente, às decisões que envolvam governo e governados. $\mathrm{O}$ povo, independentemente do alcance desta expressão na obra lockiana, representa a vontade sábia e a expressão pública a balizar e julgar a conduta do governante.

Ao corpo político, então, cabe julgar a relevância do impasse e regular exercício do direito de resistência, como resume Dunn:

Quando surge uma controvérsia entre o governante e uma parte de seus súditos, e quando o primeiro se recusa a aceitar o veredicto das instituições representativas que expressam a vontade de seus súditos, o árbitro adequado deve ser o Corpo do Povo, que nele depositou sua confiança. O Corpo do Povo pode e deve julgar, segundo sua própria consciência, se os súditos têm ou não justa causa para apelar ao Céu, para resistir a seu governante por meio da força (II 163, 243, 21). Têm o direito e o dever de fazê-lo, pois somente eles podem fundir o direito de vingança individual e a responsabilidade pela recriação da ordem política, o direito de destruir aqueles que traíram sua confiança e o dever de restaurar a confiança, sem a qual nenhuma vida verdadeiramente humana é possível na prática. (DUNN, 2003, p. 75-76).

Ora, o povo não se rebela por questões mínimas. Locke expôs as causas que tornam ilegítima a autoridade, também procurou ser didático ao demonstrar que o direito de resistência é o último dos remédios para repudiar uma injustiça. Logo, enquanto houver magistrado ou outro representante do povo que possa resolver a contenda, tal remédio não é autorizado.

A resistência é um direito de autodefesa, de preservação, que assiste ao corpo político (ao povo) em virtude da natureza e fins da sociedade: o bem público e a mútua conservação (LOCKE, 2005, II, 123).

A argumentação em torno da legitimidade da insurreição sagrada encontra força, é certo, na fundamentação de um direito natural de resistir do ser humano e do corpo político, 
os quais, instintiva ou naturalmente, evitam o poder despótico ${ }^{133}$. Ademais, a sociabilidade quase que imanente no homem lockiano leva-o a preservar a comunidade política (LOCKE, 2005, II, 77).

Talvez a opção lockiana de que a decisão da legitimidade da resistência civil cabe ao corpo político decorra de sua visão da finalidade do pacto formador da sociedade política: assegurar a preservação da vida, bens e liberdades dos homens (LOCKE, 2005, II, 122), que deve ser harmonizada com a defesa e observação do bem público, como limites do poder político (LOCKE, 2005, II, 3).

O povo ou corpo do povo é quem detém o poder de julgar eventual controvérsia que ameace a harmonia da comunidade política. Aqui, sobressai uma tendência a estabelecer uma intensa relação entre o indivíduo e a comunidade política ${ }^{134}$. O indivíduo, o homem lockiano, dotado de razão e reflexão, conhece seus direitos e obrigações, identificando-se e reconhecendo-se no outro, estabelecendo a importância da preservação da comunidade, pois:

A sociedade nasce dentro de um certo sistema de obrigações, entre seres capazes de obrigações, não nasce entre seres tão privados de toda capacidade de obrigações e, com isso, de toda significação humana, a ponto de não subsistir entre eles senão relações de força. [...] E se o estado de guerra é um crime contra a lei de natural pelo qual os homens se despojam de seu direito de homem e se igualam às feras, é precisamente porque sua sociabilidade é uma propriedade essencial a sua humanidade, e que toda ação de guerra, rompendo a unidade da espécie humana, rompe, com o mesmo golpe, a unidade da sociedade que ela constitui (POLIN, 2003, p. 167).

Locke evidencia a importância e a força do ony body politic, como forma de manter a integridade da "Commonwealth", transportando isso para o exercício do direito de resistência - desobediência civil -, que somente pode ocorrer nos casos de quebra de confiança - breach

\footnotetext{
${ }^{133}$ Observa-se que, sob o prisma lockiano, o estado civil volta-se a manter a paz possivelmente perturbada no estado natural e, embora se tenha transferido o direito de executoriedade da lei de natureza, o instinto de conservação autoriza a autodefesa (em casos particulares de ameaça imediata e presente - resistir a quem me ameaça, se não tenho como recorrer ao magistrado). Caso a situação não seja mais "flagrante", somente a autoridade política poderá fazer justiça. Sendo certo que eventual reparação de dano somente pode ser obtida através do poder público. Transpor o caso particular para o geral torna evidente que a autodefesa e a defesa da comunidade permitem a desobediência e, inclusive, pegar em armas, caso seja necessário, contra o ato irracional da autoridade política (que age contra a lei de natureza). Dessa forma, no raciocínio lockiano, não se estaria contra a lei ou contra a autoridade, pois não se pode dizer "que seja uma lei civil o ditado de alguém que quer me submeter a seu próprio arbítrio em lugar de me ajudar a seguir a Lei Natural” (MORRESI, 2005, p. 220).

${ }^{134}$ A leitura lockiana quanto à expressão "povo" não é algo confortável. Tanto que esta expressão "aparece" somente ao final do Segundo Tratado - body of the people. Ao povo cabe importante papel de sopesar o adequado exercício do direito de resistência e fomentá-lo quando necessário. Na leitura de Morresi, "quando Locke se refere ao 'povo' está implicando nesse conceito a todos os homens varões, maiores de idade e que não se declararam em Estado de Guerra, quer dizer a todos os homens livres no sentido de independentes" (MORRESI, 2005, p. 220).
} 
of trust. O homem livre e racional, com o seu voluntário consentimento, aderiu à comunidade política, assumiu inúmeras obrigações inerentes à vida em comunidade. E autorizou a sociedade a legislar em seu lugar e para ele (to make laws for him), concedeu ao povo o direito de decidir sobre o direito de resistência, uma vez que estar em sociedade significa submeter-se à decisão da maioria.

A análise das ações da autoridade política, "se foram fiéis ou não ao 'trust' ou se abusaram ou não de suas prerrogativas", cabe ao povo que detém "a soma dos poderes individuais". O povo possui este direito porque "são os direitos à segurança e à garantia das vidas, liberdades e dos bens daqueles que o compõem. São direitos porque são os fins pelos quais, sob a égide da lei natural, a sociedade foi constituída [...]” (POLIN, 2003, p. 191).

Imputar ao povo o poder de decidir sobre a legitimidade do exercício da resistência poderia torná-lo uma instância superior ao próprio legislativo - poder supremo. Todavia, Locke compatibiliza este poder, sem sobrepô-lo como uma instância superior à ordem civil estabelecida enquanto esta se mantiver legítima, pois o povo somente age - recupera o direito abdicado - quando há a degeneração do governo. Como sintetiza Raymond Polin,

o povo, cujas propriedades os governos ambicionam, ou que está ameaçado de ser escravizado por eles, está liberado de toda obediência e não tem outro recurso, para se defender contra a força e a violência, senão a força e a violência, testemunhas dos julgamentos de Deus. [...] O povo quando não mais é obrigado, por exemplo, a obedecer às leis às quais não desejou a princípio, retoma o direito de interpretar a lei natural e procura reunir a força necessária para fazê-la aplicar (POLIN, 2003, p. 190).

O natural e o político se confundem, uma vez que a lei civil nada acrescenta, mas apenas procura tornar aplicável a lei de natureza. O governo civil então não poderá se afastar deste propósito - preservação da humanidade -, sob pena de perder a sua legitimidade. Como consequência, perde também o direito - poder - de exigir a obediência do povo, pois "o representante que era ele mesmo o Governo se converteu em um ser humano irracional, que deve ser combatido como uma 'besta' (LOCKE, 1824g, II.16)” (MORRESI, 2005, p. 221).

Para Goldwin, o direito de resistência na ótica lockiana não é um direito de revolução, pois, de acordo com a lei de natureza, "não pode existir nenhum direito que traga perigo à conservação da sociedade. A revolução é uma ameaça à conservação da sociedade. Qualquer coisa que signifique o direito de resistência deve ser congruente com a conservação da sociedade" (GOLDWIN, 1993, p. 478). 
$\mathrm{Na}$ sua leitura, o direito de resistência não é um direito político, e sim um direito natural, que não pode ser exercido frente a um governo devidamente constituído ${ }^{135}$. O autor sustenta a sua idéia na afirmação lockiana de que a revolução não surge de pequenas faltas do governo, face à passividade do povo, e no fato de que Locke condena quem fomenta a revolução contra um governo justo (GOLDWIN, 1993, p. 480). O direito de resistência somente tem legitimidade quando o governo se torna um tirano e se põe em guerra contra o povo. O rebelde é o governo tirânico e o povo apenas defende a sociedade contra o tirano. Ainda, Goldwin lembra que Locke, raramente, usa a palavra revolução, preferindo a palavra rebelião, "mantendo portanto um uso estritamente literal", ou seja, na argumentação lockiana, "não existe um direito de derrubar, existe somente o direito de resistir e evitar o regresso ao estado de guerra" (GOLDWIN, 1993, p. 479).

De fato, para Locke o emprego da força pelo povo só é justificável quando for direcionado a um poder injusto e ilegal, cujos atos ameacem seus direitos naturais e quando, em consequência disso, não for mais possível apelar para a lei. O que legitima o governo é a confiança de que este cumprirá a lei de natureza, ou seja, restabelecerá a ordem natural e divina que o aparecimento da moeda perturbou (TULLY, 1980, p. 154).

Ora, na medida em que se afaste deste encargo, perde a legitimidade e o dever de obediência que lhe era devido. Nesse aspecto, a leitura do parágrafo 226 do Segundo Tratado nos leva a crer que, na verdade, o povo não estaria instaurando uma rebelião, e sim o governo ilegítimo, pois, os homens livres e iguais - formando um corpo único: o povo -- "ao entrarem em sociedade e no governo civil, excluíram a força e introduziram as leis" (LOCKE, 2005, II, 226). Logo, aqueles que revivem o uso da força em oposição às leis "são os rebellent, ou seja, que promovem novamente o estado de guerra e são propriamente rebeldes" (LOCKE, 2005, II, 226). In casu, o governo despótico - a autoridade ilegítima.

A rebelião não seria um ato do povo, e sim do governo; o povo somente resiste à rebelião do governo que atenta contra a lei, contra os fins estabelecidos a este. Uma revolução ocorreria se o povo se revoltasse contra um governo justo ou sem razões fundadas, isto é, na ausência de uma real causa de degeneração do governo. A partir do momento em que o

\footnotetext{
${ }^{135}$ Resistir ao arbítrio apresenta-se tanto como um direito individual como coletivo, o direito de rebelião é um direito de preservação de si e da sociedade, e o povo "exercerá de maneira direta e ativa o poder supremo com um único propósito: formar um novo governo tão rápido quanto for possível mediante o estabelecimento de uma constituição e a delegação do poder legislativo em outras mãos” (GOLDWIN, 1996, p. 476).
} 
governo deixa de honrar seu compromisso, também o povo encontra-se desobrigado do seu dever de obediência ${ }^{136}$.

Os argumentos expendidos por Locke, na defesa de seu direito de resistência, evidenciam bem a sua proposta. Consciente de eventuais contendas, ou seja, prevendo que "será dito, porém, que esta hipótese é um incitamento a freqüentes rebeliões" (LOCKE, 2005, II, 224), apresenta a seguinte resposta:

- O mau governo - o abuso do poder arbitrário que leva o povo à miséria - é que pode conduzir o povo maltratado a questionar os atos do governante, levando-o a buscar meios de se livrar "de uma carga que lhe pese em demasia". Independentemente de seus governantes serem "sagrados ou divinos, descendentes do céu ou por este autorizados, que sejam apresentados como quem ou o que quiserem, o mesmo sucederá" (LOCKE, 2005, II, 224). Locke sustenta que não são as ideias que fomentam a resistência, e sim o desrespeito do governante em cumprir o seu compromisso de zelar pelo bem público (LOCKE, 2005, II, 3).

- O povo não se revolta por questões mínimas, revoluções "não acontecem a cada menor desgoverno dos negócios públicos", pois o povo pode e deve tolerar até mesmo "grandes equívocos por parte dos governantes, muitas leis erradas e inconvenientes, e todos os desvios da fraqueza humana" serão relevados sem motins ou murmúrios. Apenas "uma longa série de abusos, prevaricações e ardis" que denotem a degeneração sem volta do governo é que autoriza um levante para que se possa depositar a autoridade em outras mãos, "que possam garantir-lhe os fins para os quais o governo foi originariamente constituído" (LOCKE, 2005, II, 225).

- A rebelião é um ato de força em oposição à lei e o mau governo age contrariamente à lei que visa preservar o bem do povo, logo, o rebelde é a autoridade ilegítima. O "poder do povo de prover novamente à própria segurança por meio de um novo legislativo", quando os legisladores agem contrariamente "ao encargo a eles confiado violando a propriedade alheia, é a melhor defesa contra a rebelião e o meio que mais provavelmente a evita" (LOCKE, 2005, II, 226). Locke deixa bem claro que o

\footnotetext{
${ }^{136}$ Para Alexis Tadié, a rebelião não é um ato do povo, “ao contrário, o povo resiste à rebelião dos governantes. $\mathrm{O}$ direito à revolução nasce, nesse sentido, de uma ruptura do pacto cuja responsabilidade é dos governos, o que os coloca em estado de guerra com seus súditos". E, segundo a sua leitura, o direito de resistência vai ao encontro de todos os pontos da lei de natureza, "pois a preservação do indivíduo, de sua liberdade, de sua propriedade é a garantia contra todos os atentados dos quais um poder arbitrário ou absoluto poderia se tornar culpado", uma vez que o exercício do poder absoluto, infringindo leis, "vai contra o bem comum, perde sua legitimidade, e o poder retorna então à comunidade, seu ponto de origem" (TADIÉ, 2005, p. 73).
} 
sedicioso é a aquele que, detendo a autoridade, faz uso desta contra os fins legais previamente estabelecidos, provocando a instabilidade e o mal-estar na sociedade.

Em suma, para Locke nos casos em que o "legislativo é alterado ou os legisladores agem contrariamente ao fim para o qual foram constituídos, os culpados são culpados de rebelião", estes são os rebeldes pois, embora tenham sido "instituídos para a proteção e a preservação do povo e de suas liberdades e propriedades", pela força agem contrariamente a seus fins, "colocando-se em estado de guerra com aqueles que fizeram deles guardiães e protetores de sua paz, são propriamente, e com maiores agravantes, rebellantes, rebeldes" (LOCKE, 2005, II, 227).

Qualquer questão relativa ao direito de resistência lockiano deve ser respondida com base nos seus conceitos de liberdade e de igualdade, que impulsionam racionalmente o pacto societário, para o qual os homens livres e iguais transferiram o poder natural de legislar, julgar e punir as transgressões. E isso se aplica ao governante, ou seja, o poder de destituir "o governo quando este viole gravemente o direito e se torna ameaça para os súditos. Esse é, essencialmente, o mesmo poder exercido legitimamente pelo indivíduo na condição natural [...]" (KUNTZ, 2004, p. 113).

A igualdade e a jurisdição recíprocas, decorrente da lei de natureza, é que subsidiam o direito de resistência, pois, como assinala Kuntz:

Qual o fundamento desse direito, que a sociedade recebe pelo pacto e que o
indivíduo reassume, contra um particular qualquer ou contra o governante,
quando não há autoridade para protegê-lo? Só pode ser a mesma igualdade
que a cada um converte em magistrado e executor da lei, na condição
natural. A igualdade natural nunca deixa de existir, portanto, como fonte de
direito à autodefesa e, também, de resistência à tirania [...]" (KUNTZ, 2004,
p. 114).

Locke, de fato, não estabelece um fundamento para a rebelião, ou uma apologia à desobediência civil. Estabelece, isto sim, os parâmetros para a obediência civil, uma vez que a obediência, entre os homens livres, iguais e racionais, é aquiescência, é a concordância e a participação na vida política, e não a subjugação ou mera submissão a um poder despótico.

A resistência civil é o último recurso, quando não há mais juiz a quem apelar, restando o apelo aos céus, que significa direito de defesa (do indivíduo e da comunidade), pois a sociedade política conserva eternamente "um poder supremo de salvaguardar-se das tentativas e propósitos de qualquer pessoa, mesmo de seus próprios legisladores". Esse poder supremo 
do corpo político é explicado pela natureza da relação entre governado e governante: o trust lockiano, como definido nesta passagem do Segundo Tratado:

cabe ainda ao povo um poder supremo para remover ou alterar o legislativo quando julgar que este age contrariamente à confiança nele depositada. Pois, como todo poder concedido em confiança para se alcançar um determinado fim está limitado por esse mesmo fim, sempre que este é manifestamente negligenciado, ou contrariado, o encargo confiado deve necessariamente ser retirado [forfeited] e voltar o poder às mãos daqueles que o concederam, que podem depositá-lo de novo onde quer que julguem ser melhor para sua garantia e segurança (LOCKE, 2005, II, 149).

O direito de resistência, então, deve ser interpretado sob o sustentáculo de sua doutrina: a lei de natureza, o guia das ações eternas do homem, que determina a preservação de si e da humanidade. ${ }^{137}$ A par disso, há que se lembrar quem são os homens: criaturas de Deus, racionais, livres e iguais. E é a razão que permite captar a lei de natureza e conduzir os homens a uma convivência harmônica, trazendo imbricações entre a liberdade natural e a liberdade civil.

Ora, se é certo que o homem livre é o que não se submete a nenhum arbítrio (nem ao próprio), a ideia da "não dominação" fica bastante clara nesta proposta lockiana de resistência. Yara Frateschi, sobre o tema, sintetiza:

o vínculo entre a sustentação do poder político e a confiança que os membros da comunidade emprestam ao seu depositário é um tema fundamental em Locke: o poder é legítimo e se sustenta enquanto confiança do povo. Do contrário, introduz-se um estado de guerra, isto é, um estado de força sem autoridade, e os usurpadores se tornam culpados de rebelião que será feita contra eles. E que se registre que é o povo que julga se e quando a sua confiança está sendo traída e em que mãos será novamente depositado o poder (FRATESCHI, 2008, p. 345).

O Segundo Tratado, precisamente, Ensaio relativo à verdadeira origem, extensão e objetivo do governo civil, termina com este apelo de resistência às autoridades ilegítimas. Este escrito político derruba a teoria da obrigação política baseada no direito divino, substituindo-a pela doutrina fundamentada no consentimento. A legitimidade do governo está no

\footnotetext{
${ }^{137}$ Este poder do povo, segundo expõe Paulo César Nodari, na esteira de Raymond Polin, é soberano, "não enquanto sociedade civil e multidão de indivíduos, mas como comunidade de indivíduos racionais e inteligentes, capazes de julgamentos, de intenção, de vontade de ação, considerada em seus fins, deveres e em suas liberdades na relação com os próprios governantes" (NODARI, 1998, p. 152). Desta forma, a retomada do poder não é algo inconsequente na doutrina lockiana, pois da mesma forma que Locke traça regras e limites à instituição e organização da sociedade civil, procura estabelecer regras para o uso do direito de resistência ao tirano. Locke visa afastar - diferenciar - o exercício do direito de resistência de um mero ato de vingança, pois a preservação da sociedade é algo importante e, caso a resistência deva ser exercida, este ato não será um ato irresponsável, ao contrário estará de acordo com a regra da preservação da humanidade.
} 
consentimento do povo, na confiança depositada de que cumpre a lei de natureza; daí decorre o dever de obediência. ${ }^{138}$

A leitura do Segundo Tratado sobre o Governo Civil evidencia a preocupação com a finalidade do governo e limites do poder civil. Estabelece regras, não só para o exercício do poder político, como também apresenta certos paradigmas para a noção de cidadania, de obediência e resistência civil. Apresenta regras para que o povo possa aferir a legalidade e a legitimidade do governo e assim manter a relação entre a confiança e a obediência, necessárias à organização política.

Todavia, observa-se que Locke, nos seus escritos iniciais, ao refletir sobre a autoridade civil - comando e obediência -, apresenta considerações sobre os limites do poder político e do dever de obediência civil sob uma perspectiva diferente da que foi apresentada no Segundo Tratado. Por volta de 1660, Locke escreve os Dois Tratados sobre o Magistrado Civil (Two Tracts on Government), nos quais, diferentemente do Segundo Tratado, não se preocupa com a origem do poder político.

A preocupação lockiana é a defesa da autoridade política com poder para impor regras nas questões religiosas e civis dos homens, sustentando a concessão de poderes ilimitados ao magistrado-governante e a obediência irrestrita dos súditos, pois, se a autoridade do magistrado fosse retirada, mesmo em parte, como nas questões religiosas, fatalmente entraria em colapso o seu poder político (LOCKE, 2007, p. 97) ${ }^{139}$.

A diferença de posicionamento entre o Segundo Tratado (publicado em 1689 e, provavelmente, escrito antes dessa data) e os Tracts on Government, no que concerne à obediência, impõe a leitura deste texto denominado de escrito de juventude, para que se tenha uma visão do iter do pensamento político lockiano. Na observação de John Dunn, os detalhes da argumentação lockiana importam pouco nos Tracts, mas "é necessário compreender as

\footnotetext{
138 Locke defende o governo de leis e não de homens. Logo, legislativo e soberano que desrespeitam a lei perdem o direito à obediência, pois os membros da comunidade política devem obediência "à vontade pública da sociedade" que o governante representa. Caso este "deixe esta representação, essa vontade pública", passando a agir de acordo com sua própria vontade, "degrada-se e não é mais que uma pessoa particular sem poder e sem vontade", sem qualquer direito à obediência dos membros da sociedade civil (LOCKE, 2005, II, 151).

A defesa do direito de resistência, do apelo à desobediência civil, é eloquente na fala lockiana, pois "a sociedade não pode jamais, por culpa de terceiro, perder seu direito natural e original de preservar-se". Pensar de forma contrária seria admitir a escravidão, seria como deixar alguém "sob o peso dos grilhões, e dizer-lhe que pode agir como se fosse livre". Tal condição, segundo Locke, é incompatível com a natureza humana, com o direito natural de preservar-se, que autoriza destituir um governo ou substituir o legislativo, conforme julgar mais conveniente à segurança e ao bem de todos. Isso, porque o "estado da humanidade não é tão miserável que não seja capaz de usar esse remédio antes que seja tarde demais para procurar outro" (LOCKE, 2005, II, 220).

${ }^{139}$ Utilizamos a tradução de Eunice Ostrensky, publicada pela Martins Fontes (LOCKE, 2007).
} 
linhas gerais da questão que eles abordaram e identificar as dificuldades que essa questão causou ao jovem Locke" (DUNN, 2003, p. 39), como se pretende mostrar a seguir.

\subsection{Autoridade e obediência: peculiaridade do pensamento lockiano de 1960.}

Na discussão sobre poder político, liberdade e obediência, abre-se um parênteses para trazer à baila os Two Tracts on Government, um tratado eclesiológico, que revela o seu pensamento inicial sobre o poder civil e a tolerância religiosa ${ }^{140}$.

Nos Tracts - denominados de escrito de juventude - Locke analisa as relações entre o poder político e a religião: precisamente, seu objetivo é saber se o magistrado civil pode impor e determinar usos no que se refere a coisas consideradas indiferentes no campo religioso.

Todavia, o texto não pode ser reduzido a um simples debate religioso de uma determinada época, uma vez que, na análise das esferas das relações de poder, Locke discorre sobre a finalidade do governo, sobre a liberdade e os fundamentos da obediência, bem como faz uma análise e uma classificação das possíveis leis que circundam as relações humanas ${ }^{141}$.

A reflexão envolve a seguinte questão de ordem prática: o magistrado civil pode impor e determinar legitimamente o uso de coisas indiferentes no que se refere ao culto religioso? A esta questão, Locke responde afirmativamente, num tom considerado autoritário, entendendo que, uma vez instituído o poder civil, este passa a ter o poder e o dever de regular a esfera das

\footnotetext{
${ }^{140}$ Os Two Tracts on Government, também conhecido como Opúsculo Inglês ou Dois Opúsculos Sobre o Governo ou Dois tratados sobre o magistrado civil, é uma contenda/resposta a Edward Bagshaw, que escreveu The Great Question concerning Things Indifferent in Religious Worship, datada de 1660. Nos Tracts, Locke procura combater quatro alegações de Bagshaw: 1) se os magistrados cristãos não podem impor sua religião aos judeus e muçulmanos, tampouco a podem impor aos cristãos; 2) imposições são contrárias às injunções do Evangelho; 3) imposições são contrárias à prática de Jesus Cristo e dos apóstolos; e 4) imposições são uma imprudência político-social.

141 Sabe-se que, à época, esta discussão era relevante. A expressão "coisas indiferentes", ínsita à teologia luterana, refere-se às coisas que em si não se apresentam nem como boas, nem como más. São coisas sobre as quais Deus não teria prescrito regras, seja naturalmente ou por revelação, de forma que não se conhece a vontade de Deus em tais situações. Entretanto, havia o entendimento de que, em função do poder de polícia do Estado, poderiam ser reguladas pelo poder político para melhor administração da comunidade política.
} 
coisas indiferentes - não abrangidas pela lei divina -, sendo dever dos homens confiar ao magistrado o poder sobre suas ações para a paz e a segurança social.

Locke qualifica a autoridade política como suprema, com peculiaridades nos limites da obrigação e da obediência civil, mesmo que tenha se originado a partir do consentimento entre os homens, pois:

se os homens gozam de um direito a igual liberdade, sendo iguais em virtude de seu nascimento comum, então fica claro que nenhuma união pode ocorrer entre os homens, que nenhum modo de vida seria possível, nenhuma lei, nem constituição pela qual os homens conseguiram, por assim dizer, unir-se num único corpo, a não ser que cada um primeiro se privasse dessa liberdade nativa - conforme a supõem - e a transferisse a um outro, o príncipe ou o senado (dependendo da constituição a respeito da qual tenham a oportunidade de concordar), em que o poder supremo deva necessariamente residir (LOCKE, 2007, p. 87-88).

A opção parecia clara, pois para Locke, "de fato, jamais existiu nem poderia existir uma república sem leis humanas" (LOCKE, 2007, p. 88), sendo necessária a obediência irrestrita a estas leis, pois que a primazia da ordem civil está diretamente relacionada com a estabilidade das relações sociais, bem como da ordem religiosa, precisamente do que se pode entender por liberdade religiosa. ${ }^{142}$

Assim, a tempestade e a insegurança entre os homens poderiam ser aplacadas por uma simples solução: abdicação da liberdade em favor do Estado. O magistrado civil - autoridade civil - poderia impor regras, inclusive de caráter religioso - legislar sobre coisas indiferentes. Locke explica que se deve entender por magistrado "o supremo poder legislativo de qualquer sociedade, sem considerar a forma de governo ou o número de pessoas em que está depositado" (LOCKE, 2007, p. 13, nota).

Na definição de "coisas indiferentes", Locke destaca a importância da lei para regrar a conduta humana, para estabelecer parâmetros às ações dos homens. Segundo o autor, "se não houvesse nenhuma lei não haveria bem ou mal moral" e o homem estaria abandonado a uma liberdade irrestrita em todas as suas ações. Disso decorre que "não poderia encontrar nada que

\footnotetext{
${ }^{142}$ Locke, após a definição de magistrado, acrescenta: "somente permitam-me dizer que a indelével memória de nossas recentes misérias e o feliz regresso de nossa antiga liberdade e felicidade são provas suficientes para nos convencer, sem o auxílio de nenhum outro argumento, de onde o poder supremo dessas nações está mais vantajosamente depositado" (LOCKE, 2007, p. 13, nota). Percebe-se, aqui, a que vieram os Tracts, pois Locke vivenciou grave turbulência política e religiosa. A contenda entre monarquia e parlamento fervilhava de forma intensa, e certamente os conflitos políticos da Restauração influenciaram o presente escrito. A história relata que no reino inglês forças políticas, religiosas e econômicas divergentes confrontavam-se radicalmente. Os protestantes puritanos entravam em choque com os católicos, os presbiterianos escoceses mostravam-se hostis aos anglicanos e os comerciantes revoltavam-se com as medidas financeiras do rei.
} 
não fosse puramente indiferente, e, por conseguinte, que aquilo que não está sob a obrigação de alguma lei é ainda indiferente" (LOCKE, 2007, p. 12).

A primeira autoridade suprema sobre os homens é Deus, de cuja autoridade todas as leis derivam, ou por serem prescrita por Ele, ou por serem formuladas por alguma autoridade derivada Dele. Tal qual nos Ensaios, Locke explica que a vontade de Deus se torna conhecida aos homens por meio da razão, também chamada de Lei de Natureza, ou pelas revelações de Sua palavra, impondo ao homem a submissão e a obediência, pois todas as leis dentro do alcance da lei divina são necessária e indispensavelmente boas ou más. Desta forma:

todas as coisas não-compreendidas nessa lei são perfeitamente indiferentes e em relação a elas o homem é naturalmente livre, e no entanto a tal ponto senhor de sua própria liberdade que ele pode, mediante pacto, transmiti-la a outro e investi-lo de poder sobre suas ações, não havendo nenhuma lei de Deus que proíba um homem de dispor de sua liberdade e obedecer a outrem. Mas por outro lado havendo uma lei de Deus que exija a fidelidade e a verdade em todos os contratos legítimos, obriga-o, depois de tal renúncia e acordo, a se submeter (LOCKE, 2007, p. 13).

Tudo aquilo que não está sob a obrigação de alguma lei é indiferente, ou seja, é esfera de liberdade do homem, como as "ações exteriores de cultos religiosos", que poderiam ser reguladas pelo magistrado civil. Esta afirmação decorre do fato de que é condição inerente à vida em sociedade desfazer-se da liberdade e confiá-la ao magistrado. Assim, ainda que se possa considerar que o homem seja naturalmente livre e deva sujeição somente a Deus, é condição primordial à sociedade e ao governo que todo particular se desfaça do seu direito à liberdade e confie ao magistrado um poder pleno sobre todas as suas ações.

Locke, nos Tracts, perpassa por doutrinas sobre a origem da autoridade civil, embora neste texto não considere importante destacar uma ou outra como verdadeira. Para ele, pode ser que o magistrado seja "um comissionado por Deus e por Ele encarregado do cuidado da sociedade", pode ser que a autoridade suprema e o poder de fazer leis sejam "conferidos ao magistrado pelo consentimento do povo [...] ou que o costume e o acordo geral atribuam a supremacia a certa pessoa, linhagem ou eleição [...]" (LOCKE, 2007, p. 14). Locke busca apenas enfatizar que a comunidade política necessita de regras, de leis humanas que obrigam, na medida em que se originam de um poder supremo, que não esteja sujeito à autoridade de outrem na face da Terra, condição essencial para a existência da sociedade civil. Nas suas palavras:

contudo, não ofereço nenhuma conclusão sobre essas teorias, nem considero relevante para nossa presente controvérsia [...]. Antes, afirmo: Deus desejou 
que houvesse ordem, sociedade e governo entre os homens. E isso intitulamos "república". Em toda república deve haver um poder supremo, sem o qual esta não seria verdadeiramente uma república; e esse poder supremo é exatamente o mesmo em todo governo, a saber, o legislativo. [...] o objeto e matéria do poder legislativo são todas as coisas indiferentes, e repetimos uma vez mais que o poder do magistrado se exerce sobre estas, ou então não é nada. (LOCKE, 2007, p. 88-89).

A preocupação do nosso filósofo centra-se na autoridade política como guardiã da paz, concedendo-lhe poderes ilimitados para tal. Mas, não obstante o foco principal do texto, muito se pode extrair dos Tracts, para aferir as premissas de sua futura teoria política no Segundo Tratado sobre o Governo, sobretudo no que se refere ao cuidado com a natureza humana, a existência de uma lei natural, e a necessidade de um comportamento ético - retidão nas relações -, levando-o a estabelecer uma hierarquia de leis que guiam as ações dos homens.

Este escrito de juventude, por um lado, nos parece importante por essa hierarquia de leis que organizam a contenda entre liberdade e autoridade. Por outro, no que se refere à liberdade, Locke assevera de maneira contundente que, além da submissão que ele tem "para com a autoridade", não tem menos "amor à liberdade, sem a qual o homem se acharia menos feliz do que um animal”. Mas adverte que uma liberdade geral consiste num cativeiro geral, que os defensores populares desta liberdade pública são seus maiores atravessadores e que este tipo de liberdade poderia levar ao caminho de "contendas, censura e perseguição" (LOCKE, 2007, p. 8).

Locke, sempre preocupado com a natureza humana, lembra os malefícios de uma liberdade irrestrita, face à probabilidade de que o homem não seja prudente ao utilizá-la, podendo se deixar levar por ações ambiciosas. Diante disso, para Locke,

todo remédio que se pode conseguir é quando o príncipe faz do bem do povo a medida de suas injunções, e o povo, sem examinar as razões, presta rápida e integral obediência, fundando-se as duas coisas na mútua confiança de um para com (o) outro, que é a maior segurança e felicidade de qualquer povo [...] (LOCKE, 2007, p. 7).

Segundo Locke, a liberdade não consiste em o homem, ao seu bel-prazer, intitular-se filho de Deus, tornar-se herdeiro do mundo e inverter a ordem das coisas. O autor repudia os que usam a bandeira da liberdade para "a ambição de derrubar constituições bem estruturadas, a fim de que suas ruínas possam construir fortunas para si”, critica, desta forma, os que usam a expressão liberdade para "provavelmente" envolver a todos "em perpétua dissensão e 
desordem" (LOCKE, 2007, p. 9) ${ }^{143}$. Segundo Locke, a liberdade e a lei são inseparáveis na vida em sociedade política:

toda liberdade que posso desejar a meu país ou a mim mesmo consiste em desfrutar a proteção das leis que a prudência e a providência de nossos ancestrais instituíram e que o feliz regresso de Sua Majestade restaurou: um corpo de leis tão bem composto que, enquanto se contentou apenas em estar sob ele, esta nação certamente esteve acima de seus vizinhos, forçando o mundo ao reconhecimento constante de que não apenas éramos o Estado mais feliz, como ainda a mais pura Igreja das épocas recentes (LOCKE, 2007, p. 9).

Se, por um lado, a liberdade é para Locke o fator diferenciador no homem e um bem que ele preza ao máximo, por outro, adverte que essa liberdade não pode ser ilimitada, pois geraria escravos e senhores. Refuta, assim, liberdades que possam pôr em xeque a estabilidade social. Nas suas palavras:

Quanto a mim, não existe ninguém (que) possa ter maior respeito e veneração pela autoridade do que eu. Assim que me percebi no mundo me vi no meio de uma tempestade, que durou quase até esse momento, e por isso só posso acolher a aproximação da calmaria com grande alegria e satisfação. Isso, penso eu, obriga-me em dever e gratidão a ser cauteloso com tal benção e a (fazer) o que depende de mim para tentar sua continuidade, dispondo a mente dos homens à obediência ao governo que trouxe consigo a tranquilidade e o acordo colocados além do alcance, por nossa frívola tolice, não apenas de nossa perspicácia, mas de nossa esperança (LOCKE, 2007, p. 7).

Segue-se que Locke, em meio às profundas alterações que marcaram os séculos XVI e XVII, seja no plano econômico, social ou religioso, com consequências na esfera política, num primeiro momento, interiorizou o mandamento da época: a fé se torna uma questão política - a decisão política se torna uma questão de fé.

Na sua contenda a respeito do limite do poder civil, Question concerning Things Indifferent in Religious Worship, a despeito de delinear um poder político superior às próprias leis e aos súditos governados (LOCKE, 2007, p. 79), deixa entrever a finalidade da sociedade política e o cuidado com a natureza humana, com a importância da liberdade e a importância

\footnotetext{
${ }^{143}$ A liberdade, no pensamento lockiano, é regrada não só pela Lei de Natureza - expressão maior de Deus -, mas também pela lei civil. O homem livre possui limites, sob a confiança de que o magistrado bem ordena para a primazia civil, para assegurar a paz social. O magistrado civil, segundo Locke, "é alguém que se responsabilize pelo cuidado com a comunidade". Pode ser um rei ou uma assembleia, "a quem se delegue o poder de constituir e revogar leis". Tendo o direito de mando, ele "governa e constrange outros homens e, a seu critério e por quaisquer meios, ordena os assuntos civis e deles dispõe para preservar o bem público e manter o povo em paz e concórdia" (LOCKE, 2007, p. 71).
} 
da lei para regrar a conduta dos homens. A par disso, expõe uma hierarquia entre as possíveis leis que regulam as ações humanas.

Atribuir importância à lei, definir os tipos de leis que se podem reconhecer em uma sociedade civil e estabelecer uma hierarquia entre tais leis são fatores relevantes na discussão sobre a relação de poder, consequentemente, comando e obediência. Assim, Locke, nos citados Tracts, ao analisar e justificar o poder civil, analisou também as classificações usuais de leis, ofertando-nos uma classificação que oferece subsídios à tônica da obediência civil.

Neste escrito, Locke menciona a lei natural, a lei civil e a necessidade de limites à liberdade dos homens para a garantia da paz, ante o fato real de que a liberdade ilimitada de culto externo trouxe guerras sectárias. ${ }^{144} \mathrm{E}$, ao se imiscuir nas esferas pública e privada, nas liberdades naturais do ser humano e da sua esfera de ações, Locke passa a analisar a existência de quatro tipos de regras às quais a relação entre os homens estariam submetidas, evidenciando a questão da consciência, da liberdade e dos limites, bem como da finalidade do poder civil.

Locke propõe o seguinte modo de subdividir as leis:

- Lei divina - cujo autor é Deus, é a regra e padrão de vida para os homens, torna-se conhecida pela luz da razão natural ou revelação divina. Divide-se em lei natural e lei positiva, ambas de cunho moral e se diferenciam apenas "quanto à maneira de sua promulgação e à clareza de seus preceitos". Regra maior de direito e de justiça que mostra, de forma eterna, a noção do que é o bem e do que é o mal. Desta forma, "tudo quanto essa lei alcança, seja por proibição ou ordem, é sempre em todos os lugares necessariamente bom ou mau, e todas as outras coisas que não se confinam nos limites dessa lei são indiferentes por natureza, e sua prática é livre" (LOCKE, 2007, p. 79).

- Lei humana ou política - emana da autoridade, do detentor do poder de editar leis e de mando sobre outrem, pressupondo a obediência ${ }^{145}$ - por exemplo, os comandos dos

\footnotetext{
${ }^{144}$ Nota-se certa preocupação de Locke com a natureza humana, com a possibilidade de se deixar levar por "paixões". Daí busca uma possível classificação de ações humanas como relevantes e menos relevantes. Para ele, ainda que o homem abdicasse da liberdade nas "menores", ou seja, nas coisas menos relevantes em prol da paz social, isto não significaria tolher a liberdade, bem precioso, porque a liberdade de consciência perdura e esta seria, aos olhos de Deus, bem maior na prática cristã. Nas suas palavras: "gostaria que os homens se persuadissem a ser tão gentis com sua religião, seu país e consigo próprios que não arrisquem novamente as substanciais bênçãos da glória e do acordo numa discussão ultrazelosa sobre coisas que eles mesmos admitem ser pequenas e, na melhor das hipóteses, tão-só indiferentes" (LOCKE, 2007, p. 8).

${ }^{145}$ Para Locke, sob a designação de lei humana pode-se incluir a ordem de um superior a seu inferior, sobre quem o primeiro detenha poderes legítimos, como por exemplo a relação entre pais e filhos e entre senhores e servos, nas quais filhos e servos estão obrigados à obediência (LOCKE, 2007, p. 80).
} 
magistrados, que podem abolir, confirmar ou alterar direitos particulares. Sob o título de lei humana, ter-se-ia a regulamentação das coisas indiferentes, que não estariam compreendidas nos limites da lei divina (lei mais elevada). Para Locke, não haveria necessidade de se elaborar uma lei proibindo o roubo ou exigindo a castidade, pois tais coisas são necessárias à vida social e obrigam a consciência dos súditos, independentemente de qualquer lei humana, ou seja, ainda que o magistrado "permanecesse em silêncio" (LOCKE, 2007, p. 80). Nesse particular, Locke enfatiza que Deus confiou ao magistrado a responsabilidade pelo bem-estar da sociedade e, como Ele não teria regulado todas as ações possíveis e esperadas em relação ao ser humano, cabe ao governo civil, detentor de sábia regulação, proibir e ordenar as condutas conforme requeira a situação para se alcançar o bem-estar do povo. Uma característica dessa lei é seu aspecto temporal, ou seja, ela é vigente conforme o estado das coisas - enquanto as coisas assim estão - e, caso seja abolida ou se torne inoperante, a liberdade é restituída.

- Lei fraternal ou de caridade - são comandos que restringem ainda mais nossas liberdades, nas situações deixadas em aberto pela lei divina e pela lei humana. Segundo Locke, isso pode ocorrer nas situações em que um irmão fraco, que não detenha poder sobre nós, "pode de direito próprio impedir nossa liberdade em coisas indiferentes, ainda que concedidas a nós por Deus e pelo magistrado", tornando ilegítimo em um lugar o que em outro lugar ou para outros é "inteiramente legítimo" (LOCKE, 2007, p. 81) ${ }^{146}$. A presente lei é conhecida como "lei do escândalo", lei extremamente delicada, uma vez que funde bom senso, conduta e exemplo a seguir, sob pena de se ofender outrem ou induzi-lo a algum erro ou conduta ilícita.

- Lei individual ou particular - é aquela que o homem impõe a si mesmo, tendo como fundamento a própria consciência (valor de juízo), ou um acordo com Deus, ou um acordo com os homens (vontade). Por um juízo de valor ou por sua própria vontade, coisas indiferentes, não estabelecidas previamente por leis, passam a ser obrigatórias. Na questão de consciência, há uma proposição moral sobre as coisas a fazer, pois, como explica Locke, "não é suficiente que uma coisa seja indiferente em sua própria natureza, se não estamos convencidos de que realmente é. Deus implantou a lei de natureza em nossos corações e quis

\footnotetext{
${ }^{146}$ Como exemplo, comer alimento sacrificado aos ídolos era lícito aos cristãos e não existia lei humana ou divina proibindo tal prática e, por isso, a ação podia ser considerada indiferente e inteiramente lícita. Todavia, como nem todos possuem conhecimento dessa liberdade, Locke, citando o apóstolo Paulo, 1 Cor 8,7, afirma que, nesta passagem, há uma advertência para "nos abstermos de coisas livres para não tornarmos um obstáculo a nosso irmão - preceito cuja suma é simplesmente esta: deve-se privar de coisas indiferentes e totalmente lícitas se há algum receio de que um irmão possa se ofender por tal liberdade" (LOCKE, 2007, p. 81).
} 
que houvesse um legislador interno (em vigor) constantemente presente em nós, cujos editos não nos deveria ser lícito transgredir nem mesmo por um segundo" (LOCKE, 2007, p. 82). Da mesma sorte, a limitar nossa liberdade, há o contrato, lei particular com origem na vontade, que pode ser celebrado com Deus ou com seus próprios pares. Nesta linha, Locke cita que as promessas entre os homens são também vínculos, que traçam obrigações, limitando a liberdade. Disso se depreende que, seja em função da consciência ou em decorrência de um acordo, "nossa liberdade está sob nosso comando, para abandoná-la ou ser preservada, conforme nossa escolha" (LOCKE, 1993, p. 164) ${ }^{147}$. As leis particulares, também denominadas monásticas, são regras impostas pelo próprio homem - que impõe a si mesmo criando obrigações até então indiferentes ou não exigidas pelas leis civis. Locke as subdivide em:

a) lei da consciência - juízo de valor que o intelecto faz a respeito de uma proposição moral - possível verdade - sobre as ações dos homens. Face à lei de consciência - legislador interno - há regras que não podem ser transgredidas, o que tolhe, e muito, a liberdade do homem em relação às coisas indiferentes. Segundo Locke, "nossa liberdade em coisas indiferentes é tão insegura e tão vinculada à opinião de todas as outras pessoas que se pode tomar como certo que de fato nos falta a liberdade que julgamos nos faltar" (LOCKE, 2007, p. 82); e

b) lei do contrato - deriva da vontade do homem, assumindo a forma de um pacto, que se celebra com Deus (voto - oferenda de livre e espontânea vontade) ou com os próprios semelhantes; é "promessa" entre os homens, com força vinculativa, pois oriunda da vontade e da liberdade de cada um. Em ambos os casos, tem-se a liberdade de abandonar o "pacto" ou de preservá-lo, conforme a vontade de cada um.

Ao discorrer sobre as leis regulatórias das ações humanas, Locke adverte que todas as leis mencionadas possuem, em relação à sua obrigatoriedade, um caráter divino, ou seja, as leis obrigam os homens em virtude de preceito divino no qual se baseiam. Da mesma forma, obedece-se ao magistrado porque "Deus o ordenou", o que é exemplificado por Locke com uma passagem bíblica (Rm 13, 1.5): “todos estão sujeitos à autoridade, sendo necessário que lhe estejais sujeitos, não somente por causa do castigo, mas também por causa da consciência" (LOCKE, 2007, p. 83).

\footnotetext{
147 "Promises between men have the same obligation. In both cases our liberty is at our own command, to be given up or to be preserved as we choose" (LOCKE, 1993, p. 164).
} 
Segundo Locke, as leis humanas não alteram a natureza das coisas indiferentes e, face à autoridade que possuem, tornam-se necessárias (“de indiferentes elas se tornam necessárias"), mas “apenas na medida em que isso nos diz respeito, “aqui e agora", e com relação à obrigação a que uma nova injunção, humana, possa ter temporariamente induzido e mediante a qual estamos vinculados a agir ou a nos abster". Dessa forma, por serem temporárias, uma vez abolidas ou tornando-se inoperantes, "somos restituídos à nossa antiga liberdade, permanecendo inalterada a própria coisa" (LOCKE, 2007, p. 83).

Locke ainda menciona uma hierarquia necessária entre as leis, salientando que a autoridade do magistrado se inicia onde a lei divina fixa limites à própria ação, razão pela qual tudo o que for considerado como indiferente e indeterminado encontra-se subordinado ao poder civil. Daí, segue-se que:

onde faltarem os editos da república, a lei do escândalo encontrará espaço; e apenas quando todas essas silenciam é que se observam os comandos da consciência e o voto. Tampouco permanece livre de leis superiores algo que cada indivíduo, como o senhor da própria liberdade, não possa, mediante opinião, voto ou contrato, tornar necessário a si mesmo (LOCKE, 2007, p. $84)$.

As referidas leis estão em uma ordem hierárquica, razão pela qual a lei inferior só pode intervir na esfera de ações que são indiferentes relativamente à lei superior, limitando completamente a liberdade do ser humano, pois o que uma não regula a outra pode vir a regular. Cada lei, assim, subtrai parcela da liberdade original. Por primeiro, tem-se a lei divina a limitar a liberdade humana; na esfera indiferente à lei divina, surge a lei política; e, na esfera em que esta não consegue intervir, tem-se a lei da caridade, com deveres a restringir ainda mais o livre agir do indivíduo.

Segundo Locke, há sempre um comando a dirigir as ações do homem, condicionandoo a viver entre normas e a respeitá-las. Daí a necessidade de saber se é apenas um condicionamento - obrigação -, ou se há nestas regras um valor para o homem que leva ao respeito - obediência -, por entender o seu papel natural na relação dos homens ${ }^{148}$. Locke

\footnotetext{
${ }^{148}$ Para Locke o homem já nasce sujeito a regras (seja da própria natureza, como se adaptar ao frio, calor etc., seja à Lei de Natureza, à lei civil ou ao costume, entre outras), e a boa e perfeita existência depende da compreensão e obediência a estas normas. Por outro lado, deve-se lembrar que as ponderações sobre a autoridade do poder civil surgiram numa época, de extrema agitação política e religiosa, em que o clima de intolerância era intenso, com consequências na órbita social. Nos Tracts on Government, Locke revela um pouco da natureza humana: o ser humano sujeito às paixões, necessitando de limites, pois a "liberdade ilimitada" pode trazer riscos à estabilidade das relações entre os homens e da própria. A preocupação com a segurança - garantia da paz - é o ponto central. Dessa forma, prega uma obediência ao magistrado, estabelecendo uma hierarquia de leis a pautar o ser e suas relações, de modo que tudo pareça natural, sem ares de arbitrariedade, face à "própria consciência", que estará em paz com Deus, na medida da obediência civil.
} 
opta pela imposição natural e não pela imposição social, buscando impregnar a obediência de um valor moral e ao mesmo tempo instintivo, e não de uma simples obrigação pelo medo ou situações que imponham coerção ao homem.

Locke reconhece que os homens procuram fugir da opressão, mas adverte que uma liberdade desregrada pode conduzir à desordem, ofertando ao homem "um santuário de incômodo". O desregramento pode levar à tirania ou à anarquia, flagelos mordazes que incidem sobre a humanidade, "sendo que a alegação de autoridade normalmente ampara uma e a da liberdade induz à outra - e é entre essas duas que os negócios humanos perpetuamente seguem revolvendo" (LOCKE, 2007, p. 7).

Para nosso autor, uma vez que nem todos os homens são prudentes o suficiente para se prevenirem contra a tirania e a anarquia, pois estão sujeitos a pensamentos ambiciosos ou a espíritos inquietos, como também, até que "a maior parte dos homens fique satisfeita com sua própria condição - o que não se deve procurar neste mundo", o remédio para tais flagelos ocorre quando

o príncipe faz do bem do povo a medida de suas injunções, e o povo, sem examinar as razões, presta rápida e integral obediência, fundando-se as duas coisas na mútua confiança de um para com (o) outro, que é a maior segurança e felicidade de qualquer povo e uma benção a se aguardar agora, senão sempre, e a se encontrar em meio aos inúmeros milagres que nos restauraram (e esperamos que mantenha) Sua Majestade [...] (LOCKE, 2007, p. 7).

Locke prega a obediência individual ao magistrado, independentemente de seu comportamento estar ou não em consonância com a finalidade do governo: bem comum ${ }^{149}$. Como resignação, o súdito sabe - acredita - que o soberano que estabelecer leis arbitrárias não estará em paz com Deus. Neste prisma, além do mundo material, o justo e o injusto - o bem e o mal - se confrontam, e os súditos obedientes, mas de consciência tranquila, podem alcançar a paz, o que pode não ocorrer com o magistrado injusto. Para Locke, a ordem

\footnotetext{
${ }^{149} \mathrm{Na}$ relação entre governo e governado, a autoridade civil tem certa supremacia, e a obediência à lei civil é necessária, sob pena de subverter a ordem das coisas, de a anarquia tomar o lugar do governo. Ausente uma disciplina rígida, a autoridade desaparece, a lei entra em colapso: "convulsionando-se a aparente ordem dos negócios e dissolvendo-se a estrutura do governo, cada um seria seu próprio legislador e seu próprio Deus" (LOCKE, 2007, p. 84). Locke mostra a liberdade como o direito de fazer o que as leis permitem, posto que nenhum modo comum de vida seria possível sem uma lei, e esta, por sua vez, não seria possível sem que os homens se privassem da liberdade nativa, que é transferida ao magistrado (príncipe ou senado, conforme a constituição da sociedade política), no qual o poder supremo passa a residir. Nesse aspecto, percebe-se que Locke, na procura da estabilidade social, busca pôr "as coisas em ordem", apelando "incessantemente à garantia universal da lei natural percebida pela razão ou revelada, que determina as categorias da moralidade. Essa lei se impõe à consciência do indivíduo, assim como à do magistrado. [...] Perceber essa ordem traz felicidade e tranquilidade. A teologia é a ciência que permite apreender essa ordem que a razão não cria mas descobre" (MICHAUD, 1991, p. 21).
} 
política "permanece, de qualquer forma, subordinada à lei natural divina: se o cidadão deve obediência total ao magistrado, este último é responsável perante Deus" (MICHAUD, 1991, p. 21).

$\mathrm{Na}$ defesa de seu posicionamento, Locke procura estabelecer uma diferenciação entre obrigação e liberdade, argumentando que há duas espécies de obrigatoriedade em relação as leis humanas: 1) material: relativa às leis humanas que regulam ações já consideradas necessárias por força da lei divina, independentemente da lei humana, e assim obrigam a consciência; e 2) formal: que diz respeito às determinações impostas pelo magistrado - sob outros aspectos indiferentes -, que obrigam em razão do alcance da "ordem do magistrado".

A liberdade, por sua vez, divide-se em duas modalidades: a) liberdade de julgamento: presente nas situações em que a aprovação do julgamento é irrelevante para as coisas necessárias, estando aí a liberdade de consciência; e b) liberdade da vontade: presente nas situações em que o "assentimento da vontade" não é exigido, podendo ser desconsiderado sem infringir a liberdade de consciência.

Locke, exemplificando as duas espécies de obrigatoriedade (material e formal), menciona a vedação à prática de roubo ou adultério, sendo que, nestes casos, tanto a liberdade de julgamento quanto a de consciência são suprimidas e, consequentemente, a própria consciência. Aqui, a lei não é considerada injusta porque, no confronto entre a obrigatoriedade da lei e a liberdade, a lei não "coloca novos grilhões na consciência, e tampouco o magistrado estabelece à liberdade de consciência limites distintos e mais estreitos que os fixados pelo próprio Deus" (LOCKE, 2007, p. 94).

No que se refere às leis meramente formais - obrigatoriedade formal -, Locke explica que o magistrado, por deter o poder legislativo, pode ordenar uma ação livre e indiferente, passando a ter essa lei obrigatoriedade formal. Como se trata de questão que por sua própria natureza não seria considerada material (o que vincularia por si só), vem a se tornar necessária por ordem do magistrado civil e não por sua própria natureza e, certamente, vinculando a consciência.

Para Locke, esse liame não suprime a liberdade, pois para ser obedecida exige apenas o assentimento da vontade. Nas suas palavras, as leis do magistrados, sejam "as civis como as eclesiásticas, as relativas tanto ao culto divino como à vida civil, são justas e válidas, obrigando os homens a agir, porém não a julgar; e, regulando as duas ao mesmo tempo, unem necessidade de obediência a liberdade de consciência" (LOCKE, 2007, p. 96). 
Ainda, Locke defende a obrigatoriedade da obediência em casos de leis de possível justiça duvidosa em questões de caráter eclesiástico. Neste caso, aos que afirmam que "tal poder não é nem legítimo nem tolerável", por ser impossível estabelecer "quando, afinal, o magistrado se deterá" (LOCKE, 2007, p. 96), Locke responde que o magistrado pode vir a impor uma coisa indiferente por obrigação moral a seus súditos, legislando como se a coisa fosse por si só necessária, antes da própria elaboração da lei que a tornou necessária. Segundo Locke, o magistrado, mediante tal lei, "arma uma cilada para a liberdade de consciência e peca ao ordená-la", mas tais leis, ainda assim, são obrigatórias e devem ser obedecidas, pois “são chamadas de necessárias porque são ordenadas" (LOCKE, 2007, p. 96).

De certa forma, procura explicar o poder do magistrado como necessário para o equilíbrio e a paz social e ante as possíveis leis não justas, defendendo que

basta, no que se refere à legalidade e obrigatoriedade de uma lei, se em contextos livres e indiferentes ele institui o que lhe parece, como responsável pela república, ser de algum modo conducente à paz pública e à prosperidade do povo (LOCKE, 2007, p. 94).

Sob a pressão da época, Locke buscou conciliar a liberdade, bem ínsito ao homem, com a ordem pública, sustentando que o magistrado civil poderia impor certos limites às manifestações religiosas para a garantia da paz civil. Nas observações de John W. Yolton:

não é muito difícil ouvir a voz de Hobbes em algumas dessas declarações. A defesa de Filmer da monarquia de origem divina tampouco está muito longe em muitos trechos. $\mathrm{O}$ fato de Locke não ter publicado nenhum desses escritos pode indicar uma mudança de valores e atitudes, mas esses pontos de vista são, no entanto, os que ele sustentou e colocou por escrito. Alguns foram atenuados em escritos ulteriores, outros foram completamente abandonados. A diferença de situação e contexto entre a década de 1660 na Inglaterra e a década de 1680 na Holanda (onde Locke escreveu sua Epístola) também é um fator que contribui para o entendimento da forte defesa da autoridade (mesmo quando exercida contra o bem-estar dos súditos) em 1660 e do vibrante apoio à tolerância religiosa no final da década de 1680 (YOLTON, 1996, p. 85).

Os Tracts on Government permitem uma leitura na qual a preocupação lockiana seria a própria liberdade, como fator de realização do ser humano. Os poderes conferidos ao magistrado voltam-se à defesa da liberdade frente a interesses particulares, contra as paixões que podem cegar o ser humano, fazendo-o agir pela força, aproximando-o da tirania, ou causando desordem e caos à sociedade política, implantando a anarquia. Na leitura de Ives Michaud:

os Dois opúsculos mostram um Locke surpreendente, partidário da autoridade mais do que da tolerância, da obediência ao governo mais do que 
do direito natural do cidadão à resistência contra a tirania. A autoridade do magistrado deve conter a desordem e a rebelião, proteger contra a parcialidade dos interesses e das paixões, e contra a ignorância. O perigo vem do indivíduo (MICHAUD, 1991, p. 21).

Locke, neste texto, preocupado sobretudo com a paz social e as questões religiosas, assinala a importância da lei a governar as ações humanas, prenunciando o seu sistema político (poder legislativo, acordo, finalidade do governo, consentimento e até mesmo a divisão entre o público e o privado). Já, evidenciando aqui a existência de uma lei natural (divina), verdadeira regra de moralidade, dada por Deus, captada pela razão e que, ainda que o magistrado silencie sobre a mesma, seria ordenada pela consciência: não prejudicar outrem, regra esta de validade universal.

Neste escrito que, aparentemente, o aproxima de uma "visão hobbesiana", um tanto quanto autoritária, Locke deixa entrever sua futura opção pelo elemento confiança a pautar a relação de autoridade. No Segundo Tratado, Locke, de certa forma, continua a proibir a desobediência individual, mas, apresenta um redirecionamento que envolve uma mudança de perspectiva sobre a condução da natureza humana, sobre o que o homem pode fazer por si mesmo e pela preservação da humanidade. Nos Tracts, Locke não se atém à origem do poder político, ao contrário, isso não lhe parece importante, pois apenas quer justificar e fundamentar uma obediência irrestrita à autoridade civil. Nos Dois Tratados, Locke se preocupa com a condição natural do homem e com a origem e função do poder político para explicar a relevância da obediência civil na comunidade.

O fato é que, os Tracts, datados de 1660-1661, refletiam um problema da época envolvendo as cerimônias religiosas, e, ao que se sabe, tratá-las como coisas indiferentes não resolveu a controvérsia que existia ${ }^{150}$. Da mesma forma, Locke não teve êxito com seu escrito, na tentativa de explicar a necessidade de um poder absoluto e irrestrito em relação às coisas indiferentes.

\footnotetext{
${ }^{150}$ Não podemos perder de vista que seus escritos transpassam a turbulência do século XVII, o caos político, a guerra civil e as complicações inerentes aos debates político-religiosos que se seguiram à Restauração. Segundo observa Ives Michaud, o panorama da "história inglesa é indispensável para compreender muitas das preocupações de Locke e a organização de sua obra. Sua infância se passou durante o primeiro período revolucionário. É provável que, com quatorze anos e meio, da Westminster School, de que era aluno, tenha ouvido os preparativos para a execução de Carlos I, a 30 de janeiro de 1649 [...]. São os problemas políticos levantados pela Restauração que suscitam os seus primeiros escritos: os Dois opúsculos sobre o governo (inéditos até 1961) foram escritos no fim de 1660" (MICHAUD, 1991, p. 10-11). Locke, sob a turbulência da época, fez uma opção austera, ao esboçar a autoridade do Estado, entendendo que, uma vez instituído o poder civil, cabe ao poder político regular a esfera das coisas indiferentes, sendo dever dos homens confiar ao magistrado o poder sobre suas ações.
} 
Na observação de John Dunn, Locke lidou com um problema, sem conhecê-lo ao certo. Afirmar que as cerimônias religiosas são indiferentes é tentar deixá-las à discrição humana, logo, ao arbítrio do magistrado civil, a quem cabe sobrepor-se à eventual "parcialidade voluntariosa do juízo pessoal". Para Locke, esta era a forma de se obter a paz civil, pois "a paz requeria autoridade civil, e esta, a fim de assegurar a paz, poderia fazer qualquer coisa que Deus não tivesse expressamente proibido. Nada disso esclarece muito o que, especificamente, a autoridade civil deve fazer" (DUNN, 2003, p. 42).

Locke apenas refletiu o espírito da época: a subordinação da religião à política. E, os seus escritos demonstram uma desconfiança na humanidade, nos homens que se deixam levar pelas paixões e são seduzidos pela noção de uma liberdade geral equivalente a uma verdadeira anarquia, causando a desordem social e política.

Os Tracts foram escritos em data próxima a dos Ensaios sobre a Lei de Natureza (1663-1664) e, certamente o amadurecimento lockiano sobre uma possível moral universal e sua confiança de que a boa formação pode mudar o homem, através de hábitos saudáveis, fizeram com que Locke tomasse outro direcionamento nos Dois Tratados, relativamente à explicação da obediência, sobretudo no que se refere ao homem ter consciência de como fazer uso do bem que reputa precioso: a liberdade.

O objetivo de Locke seja nos Tracts ou, seja no Segundo Tratado, é demonstrar que sem lei não há liberdade. Ainda, os Tracts, adjetivados de escritos de juventude ou de caráter hobbesiano, talvez possam apresentar uma ligação com os Dois Tratados no que se refere à proibição de resistência individual ao soberano. A leitura dos Tracts aponta para a obediência irrestrita, de caráter individual. Locke refere-se em várias passagens às "coisas" particulares, querendo regular o privado para salvaguardar o público. O seu argumento é a autoridade política sobrepondo-se à "parcialidade de juízos pessoais”.

Ora, nos Dois Tratados, Locke preocupa-se em caracterizar o governo degenerado, possibilitando ao povo identificar as premissas para uma possível insurreição. Veda "juízos pessoais" na aferição desta rebelião, pois somente cabe ao povo julgar se o ato do governante está ou não desrespeitando o "pacto original". Tanto nos Tracts como nos Dois Tratados, os homens, por viverem em comunidade política, formando one body politic, animado by the wil and determination of the majority (LOCKE, 1993, p. 310), perderam, ou melhor, renunciaram ao poder de executoriedade da lei de natureza. Não podem julgar, executar ou se rebelarem contra o governante, de forma individual. Na comunidade política, este poder-direito cabe ao povo. 
O indivíduo, homem-cidadão, como integrante de um corpo político, submete-se à maioria, logo, deve obediência ao governante, até que o corpo do povo, árbitro das contendas, julgue a fidelidade ou não da autoridade política aos fins propostos ao seu encargo. Esta opção lockiana tem como base o equilíbrio e a estabilidade das relações, salvaguardando a finalidade da comunidade política: a mútua conservação e o bem público, de eventuais interesses pessoais.

\subsection{A comunidade e o equilíbrio das relações entre os homens: premissas conclusivas}

O Segundo Tratado sobre o Governo Civil encontra-se permeado pelas seguintes expressões: lei de natureza, código de moral, liberdade e igualdade, razão, relação sociável de confiança, preservar-se e preservar a humanidade; e também Deus, Criador onipotente, onisciente e onipresente se faz perceber de forma implícita e ou explicita, nesta obra política. Em função dessas expressões é que se deve tentar responder ou refletir sobre a seguinte questão: da condição natural do homem à necessidade da comunidade política, como se resgata, preserva ou impõe a aquiescência da regra de conduta moral? Como atingir, produzir ou manter a "excelência de caráter a definir o bem agir"? 151

Segundo Locke, o homem livre, feliz e virtuoso, é o que vive sob uma regra permanente, seja esta regra a lei de natureza ou a lei civil, sendo que esta somente terá validade se estiver em conformidade com aquela. Como conseqüência, assim como a liberdade da natureza significa não estar sujeito a restrição alguma senão à da lei de natureza, a liberdade civil consiste em viver segundo uma regra permanente, elaborada pelo poder legislativo, que seja comum a todos nessa sociedade. Significa: "seguir minha própria vontade em tudo quanto escapa à prescrição da regra e de não estar sujeito à vontade inconstante, incerta, desconhecida e arbitrária de outro homem”. (LOCKE, 2005, II, 22)

\footnotetext{
${ }^{151}$ Locke iniciou os Ensaios com esta questão: "Existe uma regra de moralidade ou lei de natureza que nos seja dada?" Ao que responde, categoricamente: "Sim" (LOCKE, 2007, p. 100). Assim, para John Locke, a relação equilibrada entre os homens, precisamente, o convívio social e político, depende da aquiescência ao princípio ou lei de natureza a pautar a relação entre os homens e a relação entre governo e governado. Este é um fator importante para o convívio social, posto que esta lei, como já assinalado, pode ser equiparada com a boa moral ou virtude moral perseguida pelos filósofos de outrora (LOCKE, 2007, p. 101).
} 
Locke apregoa a boa moral ou virtude como condição necessária ao convívio social, tendo um cuidado especial em traçar condicionamentos à boa convivência. É inegável a influência do humanismo ao referir-se a um ordenamento racional do mundo para que se possa atingir o bem-estar e a felicidade. E, para isso, na sua obra Ensaio Sobre o Entendimento Humano, ao refutar a existência de princípios práticos inatos, procura delinear sua "demonstrabilidade de princípios morais" racionais e universais, debruçando-se sobre o questionamento da existência ou não de um possível princípio moral que seja observado por todos os homens, indagando:

Onde haverá uma verdade prática que seja recebida universalmente, sem dúvida nem controvérsia, como deveria sê-lo se fosse inata? A Justiça e a observância dos contratos é a matéria sobre a qual a maior parte dos homens parece estar de acordo; até nas cavernas dos ladrões e nos bandos de malfeitores se respeitam; e mesmo aqueles que hostilizam o resto da Humanidade guardam entre si tais princípios, da mesma forma que o fazem os que estão fora da lei. Mas não o fazem, compreensivelmente, como se fossem lei inatas [...) Respeitam-nas como regras de conveniência, dentro das suas próprias comunidades. [...] A Justiça e a Verdade são laços que unem toda e qualquer sociedade; não se estranhará, por isso, que até os assassinos e celerados, que romperam com todos os outros homens, se mantinham fiéis à palavra dada, de outra forma não poderiam permanecer juntos (LOCKE, 2008, p. 54-55).

A estrutura do pensamento lockiano tende para a moral como ciência, acredita assim que se possa formar uma base para a construção da moralidade, meio para se garantir o cumprimento dos acordos e da confiabilidade entre os homens. Na busca de sua ética racional ou ciência moral, Locke procura demonstrar que a ideia de justiça é comum aos homens, sejam eles malfeitores ou homens de bem. Todavia, afirma não ter sentido admitir que "observem a Justiça como um princípio prático universal aqueles que, fora do círculo restrito dos seus associados, cometem as maiores violências e vilanias" (LOCKE, 2008, p. 55). Segundo Locke, longe de ser algo inato, o respeito ou a ideia de justiça advém, para os malfeitores e ladrões de caverna, da obtenção de certas vantagens, da estrita conveniência para propiciar e manter o pacto $^{152}$.

\footnotetext{
${ }^{152} \mathrm{O}$ exemplo citado, enfocando a idéia de justiça entre ladrões e relacionamento em comum, é utilizado por Locke na sua crítica às ideias inatas e, na observação de Bobbio, a sua argumentação da "ausência de um consenso comum", uma vez que a justiça entre ladrões advém da simples conveniência, respalda-se no fato de que, "não a observam com respeito aos outros, porque isso não lhes é conveniente. Seria na verdade estranho que princípios práticos inatos pudessem ser aplicados ou não conforme a vantagem oferecida, $[\ldots]$ o consenso por si só não basta para provar o inatismo. $\mathrm{O}$ argumento ulterior, portanto, consiste nisto: não só de modo geral não há consenso entre os homens a respeito do que é o bem e o mal, mas, mesmo que houvesse, nada ficaria provado, porque esse consenso pode derivar da educação, como no caso dos povos civilizados, ou da conveniência, como no caso dos ladrões" (BOBBIO, 1997, p. 134).
} 
A justiça e a fidelidade são vínculos inerentes à sociedade, ou seja, o respeito à natureza e a obediência às regras são questões fundamentais, pois há, nos diversos ciclos ou meios de uma sociedade, a possibilidade da realização de acordos e cumprimento de obrigações. Segundo Locke, até os piores seres de uma sociedade são capazes de estabelecer pactos entre si e garantir o seu cumprimento com acertos realizados com base na moralidade prática. Qualquer pessoa pode obedecer regras, cumprir pactos e ter um senso de justiça, movido por interesses pessoais.

Aqui, Locke, na linha agostiniana, procura um diferencial para dissociar um bando de homens de um bando de ladrões: no prisma relacionamento mútuo e justiça, consente que as ações humanas tendem ao bem-estar, isto é, são voltadas à busca da felicidade e, sendo o homem um ser racional dotado de vontade, deve então cultivar suas habilidades para bem aplicar suas "próprias potências e acções, em actos com o fim de alcançar coisas boas e úteis" (LOCKE, 2008, p. 999), não só para si, mas para a humanidade ${ }^{153}$.

Nosso autor associa virtude e felicidade, dando ênfase ao estudo da ética, que "consiste na procura daquelas regras e medidas que conduzem à felicidade, e os meios de pôr em prática essas regras", e a sua finalidade é "a justiça e uma conduta de acordo com ela" (LOCKE, 2008, p. 1000). Tem-se aqui um prenúncio de uma moral racional, pois Locke afirma que

a moral é capaz de demonstração, assim como a matemática, uma vez que podem conhecer-se perfeitamente a essência real e precisa das coisas que as palavras de moral significam e assim descobrir certamente a conveniência e a não conveniência das próprias coisas, em que consiste o perfeito conhecimento (LOCKE, 2008, p. 704).

Para Locke, é possível uma construção da moral - demonstrabilidade de princípios morais - tal qual uma verdade matemática. São essas ponderações que nos levam a concluir

\footnotetext{
153 Na leitura de Peter Laslett, a teoria a respeito da obrigação e liberdade política é entendida como “desenvolvimento de uma virtude política natural”. Segundo ele, a virtude que todos nós possuímos é externa: "podemos usar a expressão utilitária e chamá-la a "visão do outro", o que implica afirmar que, no sistema lockiano, "é o poder que os homens têm sobre os outros, e não o poder que têm sobre eles próprios, que dá origem à autoridade política". Dessa forma, "não devemos considerar o governo organizado como uma forma de autogoverno", pois não somos senhores de nós mesmos e não temos o direito de nos submeter "a quem quer que seja ou a qualquer coisa. Tudo que a cooperação racional nos permite é cedermos os nossos other-regarding powers para o estabelecimento da autoridade política. Fazemos isso por um ato de consentimento e pode-se até mesmo dizer que 'as Decisões da Comunidade' são as nossas próprias decisões, tomadas que são por nós mesmos ou por nossos 'representantes' (II, § 88)'. Esta leitura exalta uma moralidade racional (e não cristã), pois o "olhar do outro" leva a uma cooperação racional para a vida em sociedade. Se nos vemos através do "olhar do outro", o "poder de consideração para com o outro" está na base da vida social, fornece a dimensão das nossas condutas. Assim, a consciência do "olhar do outro" impõe a necessidade do "nosso consenso" à obediência ao governo e a ausência de hierarquia entre os homens. Há uma construção de relacionamento moldado em função de uma virtude "natural", embora Lasllet tome isso como uma construção racional, vinda de "uma harmonia de razão entre todos nós" (LASLETT, 2003, p. 266).
} 
pela confluência da ética e da política em Locke, fundamentando a sua consciência do ser humano como sujeito de obrigações na esfera privada e pública, obediente aos mandamentos da lei de natureza.

Todavia, não obstante esta via lockiana de uma moral racional, a presença de Deus é elemento forte como fundamento da moral. A crença em Deus, cuja existência pode ser demonstrada racionalmente, ultrapassa uma simples questão de religiosidade e, paralelamente à sua construção de uma moral racional, é um fundamento moral para as relações humanas, pois,

sem ele, as ações humanas passam a não ter mais limites. É como se Locke dissesse o que Dostoievski sintetizaria séculos depois: "Se Deus não existe, tudo seria permitido". Então, cada um agiria conforme suas preferências, pondo abaixo o edifício do contrato social. Nesse caso, não se trata de direito à salvação, mas sim de dever de cada um buscá-la, o que só é possível mediante a crença em Deus (SANTOS, 2008, p. 272).

Locke, embora defenda uma moral racional, esboçada nos Ensaios e sustentada no Ensaio Sobre o Entendimento Humano, recorre sempre à figura de Deus como fundamento de toda moralidade, consequentemente, com influência nas relações políticas ${ }^{154}$. Esta é uma observação muito importante para que se possa entender o perfil do homem livre, igual e racional do Segundo Tratado.

De certa forma, Locke coloca em prática a sua ética puritana, na qual a realização da vocação - realização pessoal pelas obras - requer o uso da razão e diligente agir. Este é o dever fundamental de todo ser humano, que poderá ser punido se assim não agir, se não cumprir os desígnios de Deus.

A realização da vocação é uma questão importante para o ser humano, pois isto requer o aprimoramento (ou desenvolvimento) das habilidades dadas por Deus, o que impõe ao homem desenvolver o gosto pelo conhecimento e pelo trabalho, pois é o esforço despendido no seu cotidiano que o aproximará da felicidade, nesta e na vida celestial. Antonio Carlos dos Santos faz a seguinte síntese das ideias lockianas sobre esta responsabilidade imposta por Deus ao ser humano:

cada indivíduo é responsável pela sua própria vocação, assim como pela salvação e somente pelo trabalho ou estudo ele se realiza. $\mathrm{O}$ bem-estar terrestre deve ter funções bem estabelecidas, com fins à salvação, razão pela qual Locke critica insistentemente a avareza, o lucro e a ambição de uns e

\footnotetext{
${ }^{154}$ A teoria política e a teoria moral são tratadas da mesma forma, considerando a forma de entendimento de cada um, exprimindo convenções aceitas pelo entendimento humano. Daí a busca racional de Locke a pautar o comportamento humano, a sua preocupação com a precisão das palavras, linguagem e conceitos das coisas e da formação do juízo crítico do ser humano, sobretudo com a formação de bons hábitos.
} 
denuncia a preguiça dos pobres, mendigos, indigentes, ociosos e outros. Afirmava ele que os pobres têm origem no afrouxamento da disciplina e na corrupção dos modos e chegava a insinuar que uma família de trabalhadores não tinha o direito de admitir o ócio dos filhos após os três anos de idade. Essa também é uma das razões da insistência de Locke para que o homem trilhe o caminho da racionalidade, a fim de cumprir seus deveres morais (SANTOS, 2008, p. 269).

A religião, a crença e a fé em Deus, de um lado, e a educação - formação do homem e o exercício da razão, de outro, são os instrumentos lockianos para que se adquira a boa disposição, reconhecendo-se e evitando as más condutas, buscando-se as condutas corretas para a preservação de si e da humanidade: mandamento maior de Deus.

O perfil do ser humano descrito no Segundo Tratado, ou seja, o homem guiado pela razão, que busca a preservação da humanidade e que estabelece uma comunidade política sob uma relação sociável de confiança somente pode ser entendido com a noção do ser humano virtuoso.

Locke enfatiza o autocontrole e a necessidade deste no convívio social, sobretudo o domínio do desejo, que pode ser conseguido cultivando-se bons hábitos. Para Locke o homem livre e feliz é aquele que se liberta das perseguições dos desejos, unindo virtude e religião como fatores necessários à felicidade, pois Deus retribui a cada homem de acordo com suas ações, ou seja, os que "pelo comportamento virtuoso continuado e paciente procuram a glória, a honra e a imortalidade, terão a vida eterna; mas cada alma que pratica o mal, a indignação e a ira, terá sofrimento e a angústia" (LOCKE, 2008, p. 357).

Na construção da comunidade política, sob o fundamento de uma relação sociável de confiança, a educação e a formação, a religião e a presença de Deus, sem se descuidar do exercício da razão, são aspectos diferenciadores do comportamento humano. Caso contrário, seriam comportamentos simplesmente guiados pelo cálculo matemático ou mecanicistaracionalista. A regra moral a ser perseguida pelo ser humano é a Lei de Natureza - lei de caráter divino -, que nós é dada pelo nosso Criador e pode ser conhecida pela luz de natureza.

Para Locke, entre a vontade e o agir, há que existir um elo moral, e estabelecer o fundamento deste elo moral é fator importante para o bem agir humano. Exemplificando este seu posicionamento, expõe que:

uma regra moral importante é, sem dúvida, cumprir contratos. Todavia, se perguntarmos a um cristão, que tem em vista a outra vida e a sua felicidade ou a sua miséria eterna, qual o motivo por que guarda a sua palavra, ele responder-nos-á "Porque Deus, que tem poder sobre a morte e sobre a vida eternas, exige isso de nós". E um sequaz de Hobbes dirá, por sua parte, que é o público que assim o quer, e que o Leviatã castigará os que prevaricarem. 
Mas, se o interrogado fosse um dos filósofos da Antiguidade, responder-nosia: "Porque fazer o contrário é desonesto, abaixo da dignidade do homem, e oposto à virtude, que é o mais alto grau da perfeição humana" (LOCKE, 2008, p. 57).

Locke, unindo Deus e a Razão, afirma que os homens poderiam compreender a Lei de Natureza, bem como conduzirem-se sob uma reta moral, da mesma maneira como se compreende uma verdade matemática. Daqui se extrai um "modelo pedagógico" para o bem viver individual e social-político. Isso porque, segundo Locke, é a liberdade que o homem tem de agir conforme sua própria razão que "é capaz de instruí-lo sobre a lei pela qual ele deverá governar e de fazer com que saiba até que ponto pode dar-se à liberdade de sua própria vontade" (LOCKE, 2005, II, 63).

Nosso autor parte do pressuposto de que a própria natureza humana impõe, como algo inerente aos homens, o desejo da felicidade e a aversão à miséria, os quais, "como tais, influenciam constantemente nossas acções e podem ser observados em todas as pessoas e em todas as idades" (LOCKE, 2008, p. 55-56).

Na construção de um conceito de cidadão e da definição de obediência civil, há que se lembrar que Locke inicia seu Segundo Tratado lembrando a condição natural do homem. E, embora não estabeleça uma discussão acerca da natureza humana, destaca a sua preocupação com as tendências que o ser humano pode apresentar, podendo deixar de ouvir a razão e se entregar às paixões humanas, comprometendo o convívio social e político.

$\mathrm{Na}$ medida em que reconhece este aspecto da natureza do homem, certas inclinações naturais, em virtude das quais há coisas que nos agradam ou nos atraem e outras que nos desagradam ou causam repulsa (LOCKE, 2008, p. 56), Locke reconhece o importante papel da religião e da educação na formação e educação dos homens. O reconhecimento de certas propensões humanas é aspecto delicado no julgamento das próprias ações humanas, que pode comprometer a noção do que seja o certo e o errado, do que se deva entender por honesto e o desonesto $^{155}$. Todavia, Deus sendo a fonte da moralidade, evita-se a possível discordância de opiniões e julgamentos das ações entre os homens, pois há um só Deus, um só propósito: a glória do Senhor.

\footnotetext{
${ }^{155}$ Para Locke, deve-se levar o homem a perceber que a virtude e a religião são necessárias a sua felicidade, percebendo Deus como o Juiz justo que retribuirá a cada um conforme a sua obra. Neste prisma, os virtuosos que, de forma continua e paciente procuram a glória e a honra, terão vida eterna, mas os que praticam o mal terão sofrimento e angustia (LOCKE, 2008, 357). Esta percepção é que proporcionará a vida em harmonia, seja no aspecto social ou político.
} 
A relação moral implica a concordância ou desacordo das ações voluntárias dos homens (ações morais) em relação a uma regra à qual eles se referem e pela qual eles são julgados, punidos ou recompensados, conforme a vontade do legislador. Pensar um mundo cujos homens pautem suas condutas, de forma racional, pelos ensinamentos crísticos traz uma certa peculiaridade para se refletir sobre a autoridade política. Tanto mais quando se apresenta, a pautar a ação dos homens, a regra: "não faças aos outros senão o que gostarias que fizessem a ti” (LOCKE, 2008, p. 56).

A par da preocupação com o cuidado espiritual, precisamente, a crença em Deus, como uma questão imperiosa na construção da moralidade, sob uma ótica cristã, voltando-se para a caridade e boa vontade para com os outros, Locke, para garantir um comportamento reto no ser humano, preocupou-se com a educação ${ }^{156}$. Esta vem a ser um instrumento importante para garantir o desenvolvimento de pessoas livres, conscientes, com pensamentos e ações voltadas ao bem-estar próprio e da humanidade. Segundo Locke, os enganos, as falsas crenças e as confusões reinantes no mundo advêm da desobediência da lei de natureza e da própria falta de conhecimento do ser humano.

\footnotetext{
${ }^{156} \mathrm{Na}$ construção da moralidade, a formação do homem possui papel vital, tal qual a crença em Deus Locke, em todos os seus escritos, sempre expressou muito cuidado com isso, com a formação dos bons hábitos e o cultivo da virtude, e com a importância da lei a regular as relações humanas. Importava-se muito com a elaboração e classificação da lei, pois é a esta que as relações entre os homens e suas ações estão submetidas. No Ensaio, Locke enfatiza que as leis, sob as quais os homens se relacionam, estabelecendo julgamentos e definindo o que é retidão ou prevaricação, podem ser compreendidas em três tipos: lei divina, civil e de opinião. A lei divina é a medida do pecado, do dever e do respeito, estabelecida por Deus e promulgada "pela lei de natureza ou pela voz da revelação divina". Este é o critério único e verdadeiro da retidão moral. A lei civil, por sua vez, são as regras estabelecidas para o convívio em comunidade política, pelas quais se julgam as ações em criminosas ou não, com as recompensas e castigos que lhe são inerentes, forçando a sua obediência. Tais regras extraem sua força da própria comunidade, "empenhada em proteger as vidas, as liberdades e os bens daqueles que vivem de acordo com as suas leis, e tendo o poder de tirar a vida, a liberdade e os bens àqueles que a desobedecem; e estes são os castigos resultantes das ofensas à lei civil" (LOCKE, 2008, p. 468). Já a lei de opinião define o que são a virtude e o vício, estabelecendo as condutas como certas ou erradas pelo costume e opiniões, "através de um consenso secreto e tácito", que se "estabelece nas diversas sociedades, tribos, e clubes de homens de todo o mundo; de onde diferentes acções encontram a aprovação ou o descrédito de acordo com o juízo, máximas e costumes desse lugar" (LOCKE, 2008, p. 468-469). A obediência a esta lei advém do desejo de gozar de boa reputação entre seus pares. Tais leis deveriam se identificar com a lei divina, todavia, pondera Locke, os homens, não raro, afastam-se do comando divino e deixam de ouvir a razão, considerando como vício e virtude a aprovação ou a aversão do grupo, independentemente da conexão destas com a lei divina. Nesse enfoque, os homens, embora organizados em sociedade política e estabelecendo regras públicas, dotadas de força, a ser aplicada a seus pares nos termos da lei vigente, asseguram-se da possibilidade de julgarem bem ou mal, de aprovarem ou não "acções daqueles com quem vivem e com quem conversam, e a partir desta aprovação e desaprovação estabelecem entre eles o que irão designar como virtude e vício" (LOCKE, 2008, p. 469). Esta lei possui relevância no seio social, não raro mais que as outras leis, exercendo grande ascendência sobre os homens, sobrepondo-se à lei civil e à lei de natureza. Sob a influência dos costumes, os homens julgam a virtude ou o vício em função de um consenso de alguns, para manterem-se bem com seus pares, seja sob a promessa da impunidade, ou por buscarem não cair em descrédito ou castigo de censura, evitando conduta contrária aos costumes e opiniões da comunidade em que vive, subjugando-se a esta. Eis a grande razão, pela qual Locke, a par do conhecimento de Deus e da importância da religião, preocupou-se com a formação do ser humano, com a busca do conhecimento verdadeiro, a impedir que a imaginação ou falsas crenças tornem-se verdadeiro desastre na vida do homem, provando julgamentos errôneos como se fossem "verdades matemáticas" atrapalhando o seu senso crítico.
} 
Este homem livre, que reconhece o outro como igual, que obedece à Lei de Natureza, é o homem delineado no Segundo Tratado que se compromete com todo o gênero humano. Isso porque Locke não fala de um direito dos homens de se respeitarem uns aos outros, mas de um dever do homem em relação ao gênero humano e em relação a toda a humanidade, como Deus quis que fosse (POLIN, 1960, p. 186) ${ }^{157}$. Da mesma forma, o abandono da força e da liberdade natural é necessário para a segurança da sociedade e isso, segundo Polin, não é somente uma necessidade teológica, mas de razão e de justiça, porque todos os membros fazem o mesmo (POLIN, 1960, p. 193). O compromisso com a preservação da humanidade e não somente com a autopreservação impôs a organização política que possui como finalidade a persecução do bem público.

A obediência civil, o dever fundamental em acatar as leis da comunidade política, decorre num primeiro momento da própria consciência e obediência da Lei de Natureza, que impõe a submissão do ser humano ao que for necessário para a preservação da humanidade. A par disso, o reconhecimento dos homens como seres livres e iguais impõe a regra de que o estabelecimento do poder político - poder de editar leis - necessita do consentimento destes, que, uma vez organizados politicamente, com a consciência da finalidade da sociedade política, serão guiados pela maioria na condução política da sociedade. O consentimento implica o reconhecimento da confiança entre os integrantes da comunidade política, e entre estes e os escolhidos como governantes. O poder político com poder de editar leis significa, em última instância, que aquele que detém o poder de elaborar a lei tem a confiança dos que representam neste ato: o povo.

O povo possui participação na elaboração da lei que irá comandar suas ações, o que implica afirmar que a obediência civil em Locke aproxima-se de uma participação política na condução da sociedade civil, pelo voto livre e consciente. Os homens livres e iguais obedecem à lei, que de certa forma elaboraram através daqueles a quem depositaram o voto de confiança de que cumpririam os objetivos da sociedade civil. O homem racional e virtuoso está sob um governo de leis e não de homens arbitrários que se deixam levar por interesses próprios.

A crença na própria humanidade e no que é preciso executar para a preservação desta é que impulsiona a obediência civil no pensamento político lockiano, por isso os homens

\footnotetext{
${ }^{157}$ No pensamento político lockiano, a obediência à lei de natureza - mandamento de Deus - aproxima o homem de uma conduta virtuosa. Atribuir ao ser humano o caráter racional e virtuoso implica afirmar que a sua preocupação primeira será a preservação de si e da humanidade e não o autointeresse. O homem racional e virtuoso é o homem livre, cujas ações possuem como parâmetro a razão e a Lei de Natureza.
} 
depositam o seu poder originário na sociedade e não podem retomá-lo enquanto durar a sociedade. $\mathrm{O}$ dever de obediência persiste enquanto persistir o elo de confiança na autoridade política, enquanto este cumpre os desígnios da Lei de Natureza.

Locke encerra o Segundo Tratado sobre o Governo Civil, delineando a relação entre liberdade e a obediência, sob o elo da confiança, ao estabelecer que, enquanto o governo cumpre o seu papel, o povo deve obedecê-lo, mas, caso cometa alguma falta, cujo povo será juiz, o poder confiando ao governo retorna à sociedade, pois:

o povo tem o direito de agir como supremo e continuar o legislativo em si mesmo, ou instituir uma nova forma, ou ainda, sob a forma antiga, colocá-lo em novas mãos, conforme julgar adequado (LOCKE, 2005, II, 243).

A compreensão do estabelecimento da comunidade política e do poder político, no enfoque da relação de confiança entre os homens, exige a definição da Lei de Natureza, de um certo entendimento da natureza humana e da finalidade do homem na visão lockiana. Este é o caminho para a compreensão da ruptura do estado de natureza e a consequente passagem ao estado civil através do processo peculiar do consentimento de homens livres e iguais ${ }^{158}$.

A doutrina lockiana é, usualmente, designada de liberal - individualista. No entanto, até que ponto pode-se afirmar que o ideário político de Locke quer apenas afirmar o governo como meio (aparato administrativo) para se atingir o interesse de uma sociedade individualista, formada por sujeitos privados, voltados exclusivamente para interesses privados?

Nos escritos lockianos não encontramos expressamente a draconiana virtude cívica austera moralidade e devoção sacrificial à pátria e ao bem comum. Mas a norma mandatória da Lei de Natureza prescreve a preservação de si e de toda humanidade, aliada à determinação de que o acatamento da mesma visa ao interesse da coletividade (Ensaios VIII), traz, a nosso ver, o repúdio ao individualismo e a tentativa de compatibilizar o público e o privado ${ }^{159}$.

\footnotetext{
${ }^{158} \mathrm{O}$ artifício da organização social leva em conta os seres livres, iguais e racionais, cuja base da convivência baseia-se no princípio da confiança: todos agem de forma a seguir os preceitos da Lei de Natureza - um não deve prejudicar o outro. Todos são criaturas de Deus (igualdade e ausência de subordinação), criadas para cumprir os desígnios do Criador: crescer e multiplicar. Logo, devem se preservar e preservar a toda a Humanidade, para uma melhor vida terrena e no Além, quando voltarem ao Pai Criador. Este é um argumento da qual Locke nunca se separou: a vocação puritana.

${ }^{159}$ Nesta linha, a permitir a discussão sobre civismo e virtude, lembra-se que Locke, na sua obra Alguns Pensamentos Acerca da Educação, ao discorrer sobre o "espírito" e "os caprichos", enfatiza que: "depois de tomar as devidas precauções para conservar o corpo forte e vigoroso, para que se possa obedecer e executar as ordens do espírito, a próxima e principal tarefa é a de tornar reto o espírito para que esteja sempre disposto a não consentir a nada que não esteja conforme com a dignidade e excelência de uma criatura racional” (§ 31).
} 
Evidencia a máxima que pode tornar o indivíduo cidadão comunitário: que "sendo todos iguais e independentes, ninguém deveria prejudicar a outrem [...]” (LOCKE, 2005, II, 6).

Ora, estas considerações talvez não façam de Locke tão somente um disseminador da ideologia das abelhas egoístas, mas sim, na esteira de Eunice Ostrensky: "um agente do mais ambicioso programa de construção do Estado jamais compreendido pelos governos ingleses" $\left(\right.$ OSTRENSKY, 2007, p. XXXI) ${ }^{160}$.

Neste ambicioso programa de construção de Estado, Locke trabalha os conceitos de liberdade e igualdade evidenciando o ser humano como sujeito de obrigações - obrigações para com Deus, para com o outro e a humanidade, fomentando a relação de confiança entre todos e o cuidado com o gênero humano. A crença de que os homens agirão na confiança de que todos vão agir da mesma forma - preocupados, não com o interesse próprio, mas com a coletividade - explicita a teologia natural presente na sua concepção política, revelando um tratado moral a subsidiar a obediência civil.

$\mathrm{Na}$ visão lockiana, as noções de sociedade, liberdade e obediência devem ser entendidas sempre com base no elo natural entre os homens: a igualdade e a confiança, base de qualquer possível relação. Esta base é ditada pela Lei de Natureza. Todavia, a compreensão do conceito de confiança em Locke requer a assimilação da sua concepção de ser humano, do papel e importância do conhecimento, da razão e do assentimento - da formação da crença e da opinião.

A noção de confiança está longe de ser mera credulidade cega e insana. Locke trabalha o senso crítico paralelamente ao elo de confiança nos seres livres, racionais e iguais. Pois no seu pensamento político:

o governo é uma relação entre homens, entre criaturas que podem merecer confiança, mas podem, às vezes, traí-la. Confiança é um dos termos mais antigos presentes no pensamento de Locke. O caráter indispensável e o risco da confiança são fundamentais para a existência humana. Como ele escreveu em 1659, os homens "vivem com base na confiança". [...] A linguagem pode ser "o grande Instrumento, e o Laço comum da Sociedade" (E 402): porém, o que lhe confere o poder de unir os homens, na prática, é sua capacidade de expressar seus compromissos solenes sobre os quais se baseia necessariamente sua confiança recíproca e que constituem os vínculos (vincula) de sua vida comum (LT 134) (DUNN, 2003, p. 71-72).

\footnotetext{
${ }^{160}$ Embora não seja objeto do presente trabalho, vale citar as considerações feitas por Mariano Grondona sobre as ideias liberais e o egoísmo, para quem, na confluência entre individualismo e solidariedade: "basta recordar aquela observação de Karl Popper em A sociedade aberta e seus inimigos, onde adverte que os pares de conceito individualismo/coletivismo e egoísmo/altruísmo são reciprocamente independentes. Há individualistas egoístas e altruístas, assim como há coletivistas altruístas e egoístas. Um 'liberalismo solidário' não só é possível mas desejável" (GRANDONA, 2000, p. 14).
} 
A proposta lockiana da obediência civil representa um ato dinâmico próximo do ser humano como cidadão consciente. Obedecer é dar o seu consentimento, é participar das decisões do poder político elaborando as leis que vão regular as condutas de todos os integrantes da comunidade política através dos representantes, é seguir a maioria na condução do governo, que encontra seu limite e fins no bem público.

A obediência, embora indispensável, está condicionada ao respeito por parte do governante dos limites e fins preestabelecidos ao exercício do poder, ou seja, não poderá ser arbitrário, não poderá exceder-se nem em relação ao que lhe foi conferido pelo pacto e nem em relação aos poderes individuais que os homens tinham no estado de natureza. $\mathrm{O}$ arbítrio, o uso da força, ofende não só uma vítima (pessoa individual) ou um determinado povo, mas sim toda a humanidade - o gênero humano -, pois ofende a própria Lei de Natureza, base da lei civil que determina a preservação de si e da humanidade.

Locke concilia liberdade e obediência, o que requer pessoas conscientes de seu próprio papel na comunidade. O ser humano, razão e reflexão, guiado pela Lei de Natureza, desenvolve uma consciência de obrigação política e de liberdade civil compatível com uma tendência a harmonizar a esfera pública e a privada. Locke, certamente, caminha para o que se pode denominar de virtude política, na medida em que compatibiliza a igualdade e a liberdade de todos, pois a ausência de subordinação leva à institucionalização de um poder comum guiado pela decisão da maioria. A decisão do governo corresponde à decisão de cada homem livre e igual, que, conscientemente, escolheu seu representante para elaborar a lei que governará a todos.

Mais que um simples consentimento, ao abandonarem o estado de natureza e formarem "um povo, um corpo político sob um único governo supremo", os homens livres e iguais autorizam "a sociedade ou, o que vem a ser o mesmo, o legislativo desta a elaborar leis em seu nome segundo exija o bem público, a cuja execução sua própria assistência (como se fossem decretos de sua própria pessoa) é devida" (LOCKE, 2005, II, 89). O todo (corpo político) se volta ao bem comum, que somente pode ser explicado e entendido levando-se em conta o ser racional, que é guiado pela Lei de Natureza, a qual impõe a preservação de si e da humanidade.

A construção da imbricação ética e política lockiana é patente. Locke encaminha-se para a formação do homem cidadão - construção da cidadania -, de um certo civismo, pois a sua busca por uma resposta à questão "Como os homens devem viver, como podem 
conhecer?", de certa forma, leva a uma consciência ética e política, possibilitando o compromisso de um pacto societário com fundamento na Lei de Natureza ${ }^{161}$.

Para Locke, as promessas e juramentos obrigam até a Deus, logo, os homens, criados à imagem e semelhança Deste, obrigam-se reciprocamente, fazendo e cumprindo promessas e juramentos - compromissos recíprocos -, mantendo a unidade que Deus planejou aos homens. E, à "medida que traem a confiança uns dos outros, ajudam a promover sua desintegração" (DUNN, 2003, p. 72), contrariando o mandamento da Lei de Natureza: preservar-se e preservar a humanidade.

A confiança como elo para a vida social, no prisma lockiano, evidencia o seu tratado moral a regular a vida privada e a pública. $\mathrm{O}$ agir racional, o respeito mútuo, implica o estabelecimento de uma comunidade política, na qual governante e governados pautam-se pela Lei de Natureza.

A busca da virtude social e política obsta ações arbitrárias, o que dificulta o aparecimento de causas que possam gerar eventual resistência individual ou coletiva, pois o mandamento da assistência mútua seria a máxima a ser perseguida por todos. Isso, no entanto, requer o cultivo da virtude natural, do que Locke chama de "bem educar para o bem viver", evidenciando a "virtude, a prudência, boas maneiras e o conhecimento", quatro "elementos ou características" fundamentais que identificam o homem verdadeiramente livre, reconhecendo o seu semelhante como verdadeiramente um igual ${ }^{162}$.

Formar uma comunidade política de homens livres e iguais significa, em primeiro lugar, que todos devem agir de acordo com suas obrigações (deveres) para que tenham o direito de bem viver. O homem já nasce livre e racional, mas, para atuar de forma racional e

\footnotetext{
${ }^{161}$ Locke sempre teve a preocupação de descrever o homem como um sujeito de obrigações para o "bem viver". A formação do ser humano sempre foi tema vital nas suas reflexões. Seu pensamento, seja político, social ou epistemológico, é pautado por uma teologia. Para ele, os homens possuem um fim único e a união destes, em torno do mesmo fim, proporciona o bem agir individual e do corpo político. Daí a sua preocupação com o conhecimento, com a educação e a formação de opinião, considerando os grandes reflexos na política - nas decisões políticas, no consentimento e na decisão da maioria, como participação política consciente.

${ }^{162}$ Em Alguns Pensamentos acerca da Educação ( $\$ 94$ e 140), Locke afirma que o que se pode legar aos filhos, além de bens, é a melhor educação, e esta consiste no desenvolvimento de quatro qualidades essenciais ao homem: virtude (virtue), prudência (wisdom), boas maneiras (breeding) e conhecimento (learning). Segundo Locke, as duas primeiras são fundamentais ao homem, mas a mais importante, tanto para um cavalheiro como para um homem comum, é a virtude, pois é ela que fornece ao homem a base necessária para o conhecimento de seu dever, proporcionando-lhe prazer pelo simples fato de cumprir os desígnios do Criador. A virtude significa obediência à Lei de Natureza, que é captada pela razão. No prisma lockiano, a compreensão das faculdades cognitivas e seu legítimo e adequado emprego salvam o homem da ociosidade e do ceticismo, levando a práticas virtuosas - a bons hábitos. Assim, segundo Locke, compete ao homem, e "está inteiramente a seu alcance aperfeiçoar o conhecimento daquilo que se situa dentro do seu campo de visão, e aí conta-se tudo o que diz respeito à conduta e à fidelidade, sua verdadeira vocação" (JORGE FILHO, 1992, p. 23).
} 
comportar-se de acordo com o seu dever, deve guiar-se pela lei civil que, por sua vez, segue a Lei de Natureza, descoberta pela razão, imprimindo um código de ética ao ser humano e às suas relações ${ }^{163}$.

A condição de homem livre e igual não impõe a condição de isolamento com valores egoístas, pois se pode entender que, como criaturas de Deus, os homens nascem livres e racionais e se voltam a cumprir os desígnios de seu Criador, devendo bem agir na Terra para poderem ter uma boa vida terrena (bem como no Além). Logo, por ser o homem razão e sensação, os propósitos divinos somente serão atingidos na medida em que tenham consciência de si e de seus deveres e, este é o primeiro passo para a formação do homemcidadão.

A justificativa da sociedade política, no pensamento político lockiano, tem sido ligada à segurança e à defesa da propriedade privada - direito de elite. No entanto, Locke nos apresenta um projeto político-pedagógico que, longe de ratificar um direito de minoria proprietários de bens materiais -, pode nos mostrar um Locke preocupado com a formação do homem-cidadão - proprietários de si mesmos na medida em que suas ações estão em conformidade com a lei de natureza -, o que leva o ser humano a se reconhecer como um sujeito de obrigações e não exclusivamente de direitos.

A análise lockiana da finalidade do homem, criatura de Deus, que tem um compromisso com a humanidade, com o gênero humano, cônscio de seu papel, apresenta-se como uma espécie de tratado moral a subsidiar o agir político. Desta forma, a própria consciência é que move a obediência à regra de moralidade (Lei de Natureza), cuja base é o interesse da coletividade, com conseqüências na esfera política. Esta é a essência de seu pensamento político que, de certa forma, pode nos levar a repensar nossa própria prática político-participativa e reconhecer a relevância da imbricação entre Ética e Política, no agir consciente do homem-cidadão.

\footnotetext{
${ }^{163}$ Locke, a seu tempo e a seu modo, prega o agir consciente, esposando a tese do agir secundum rationem e cum ratione, seguindo a esteira aristotélica de Tomás de Aquino, para quem "a virtude moral não pode ser somente segundo a reta razão, secundum ratione, pois, desta maneira, alguém poderia ser virtuoso sem possuir a prudência, sendo, por exemplo, instruído por uma outra pessoa. É preciso ir além e dizer que a virtude é uma disposição cum ratione, pois então a razão funciona como um princípio interno do agente, que age, portanto, próprio motu" (ZINGANO, 2007, p. 366).
} 


\section{BIBLIOGRAFIA:}

ABBGNANO, Nicola. História da Filosofia, tradução Antonio Ramos Rosa, Vol 6, Lisboa:Editorial Presença, 2000.

ALMEIDA, Maria Cecília Pedreira de. Escravos Súditos e Homens: A noção de Consentimento na Polêmica Locke-Filmer, Dissertação apresentada ao Departamento de Filosofia, da Faculdade de Filosofia, Letras e Ciências Humanas da Universidade de São Paulo, para obtenção do título de Mestre em Filosofia. São Paulo: 2006.

AYRES. MICHAEL. Locke: Idéia e Coisas, tradução José Oscar de Almeida Marques, São Paulo: Editora Unesp, 2000.

ARISTÓTELES. A Política. Tradução Nestor Silveira Chaves, Coleção Universidade Ediouro - Rio de Janeiro: Tecnoprint S. A.

Ethica Nicomachea I 13 -III 8 - Tratado da Virtude Moral. Vol. I, tradução Marco Antonio de Ávila Zingano, São Paulo: Odysseus Editores, 2008,

ASHCRAFT, Richard. Revolutionary politics \& Locke's two treatises of government, Princeton, N.J.: Princeton University Press, c1986.

BARROS, Alberto Ribeiro Gonçalves. Direito Natural em Cícero e em Tomás de Aquino. In: Direito e Justiça: a noção de justiça na história da filosofia. São Paulo: Atlas, 2007.

Direito Natural e Propriedade em Jean Bodin, in TRANS/FORM/AÇÃO Revista de Filosofia, n. 29, n. 1, p. 31-43, Unesp, 2006. Direito de Resistência na França Renascentista, in Kriterion, v 113, p. 99$114,2006$. A Teoria da Soberania de Jean Bodin, São Paulo: Unimarco Editora, 2001.

BENJAMIN, Cássio Corrêa. Uma análise da crítica hegeliana ao modo empírico de tratar o Direito Natural representado por Hobbes e Locke. Dissertação apresentada ao Curso de Mestrado em Filosofia, da Faculdade de Filosofia e Ciências Humanas da UFMG, para obtenção do título de Mestre em Filosofia. Belo Horizonte: 1997.

BITTAR, Eduardo C. B. Curso de Filosofia Política, São Paulo: Atlas, 2008. 
BOITEUX, Elza Antonia Pereira Cunha. Prefácio, in Liberalismo e Natureza: A propriedade em John Locke, Cintra, Rodrigo Suzuki, São Paulo: Ateliê Editorial: Ateliê Editorial, 2010.

BOBBIO, Norberto. Estado, Governo e Sociedade: Por uma teoria geral da política, tradução Marco Aurélio Nogueira, Rio de Janeiro: Paz e Terra, 2007

Teoria Geral da Política, tradução de Daniela Beccaccia Versiani, Rio de Janeiro: Campus, 2000.

e outros. Dicionário de Política, tradução Carmen C. Varriale e outros, vol. I e II, Brasília: UNB, 1999.

Igualdade e Liberdade, tradução de Carlos Nelson Coutinho, Rio de Janeiro: Ediouro, 1997.

Locke e o Direito Natural, tradução Sérgio Bath, Brasília: Editora Universidade de Brasília, 1997.

BREHIER, Émile. História da Filosofia Politica, tradução Eduardo Sucupira Filho, São Paulo: Mestre Jou, 1977.

CAVAlCANTI, Afonso de Souza. A Politica no confronto entre os pensamentos de Thomas Hobbes e John Locke: por uma Ética Política. Dissertação apresentada ao Curso de Filosofia - Pontífica Universidade Católica de Campinas, para obtenção do título de Mestre em Filosofia, Campinas:1998 .

CARDOSO, Sérgio. Do Desejo à Vontade, Discurso, Revista do Departamento de Filosofia FFLCH/USP, Ano V, n. 6.

CHATELET, Francçois, DUHAMEL, Oliver e KOUCHNER, Evelyne Pisier-. Histórias das Idéias Políticas, tradução Carlos Nelson Coutinho. Rio de Janeiro: Jorge Zahar Editor, 1994.

CHEVALLIER, Jean-Jacques. As Grandes Obras Políticas, tradução Lydia Christina, Livraria AGIR Editora, 1989.

CÍCERO, Marco Túlio. Dos Deveres, tradução Alex Marins, São Paulo: Martin Claret Ltda., 2007.

Do sumo bem e do sumo mal, tradução Carlos Ancede Nougué, São Paulo: Martins Fontes, 2005. 
CINTRA, Rodrigo Suzuki. Liberalismo e Natureza: A propriedade em John Locke, São Paulo: Ateliê Editorial: Ateliê Editorial, 2010.

COMPARATO, Fábio Konder. ÉTICA: Direito, Moral e Religião no Mundo Moderno, São Paulo: Companhia das Letras, 2006.

CORCUFF, Philippe. Filosofia Política, tradução Duarte da Costa Cabral, "Coleção Saber", Publicações Europa-América, 2003.

DUMONT, Lous. O individualismo, tradução Álvaro Cabral, Rio de Janeiro: 1985.

DUNN, John. Locke, tradução Luiz Paulo Rouanet, São Paulo: Edições Loyola, 2003.

La pensée polítique de John Locke, tradução do inglês por Jean-François Baillon. Paris, PUF, 1991.

DUSO, Giuseppe (org.). O Poder: História da Filosofia Politica Moderna, tradução Andrea Ciacchi, Líssia da Cruz e Silva e Giuseppe Tosi, Petrópolis, RJ: Vozes, 2005.

GOYARD-FABRE, Simone. Princípios Filosóficos do Direito Politico Moderno, tradução Irene A. Paternot, São Paulo: Martins Fontes.

FARR, James. Locke, Natural Law and New World Slavery, in Political Theory, published, online, May 6, 2008 : http://ptx.sagepub.com - http://ptx.sagep ub.com/cgi/conte nt/abstract/36/4/495

FILMER, Robert. Patriarch and other writings. Cambridge: Cambridge University Press, 2004,

FRANCO, Maria Sylvia Carvalho. All the world was América: John Locke, liberalismo e propriedade como conceito antropológico, in Revista USP, vol 17.

FRATESCHI, Yara. John Locke: estado e resistência, in Curso de Filosofia Política, org. Ronaldo Porto Macedo Jr., São Paulo: Atlas, 2008, p. 323-349.

GARCIA, Florivaldo. Investigar por natureza, in Revista Filosofia Especial - Ciência e Vida - Ano I, n. 5, São Paulo: Editora Escala.

GHIGGI, Gomercindo e OLIVEIRA, Avelino da Rosa. O conceito de disciplina em John Locke. Porto Alegre: EDIPUCRS, 1995. 
GOLDWIN, Robert A.. John Locke, in: STRAUSS, Leo; CROPSEY, Joseph (org,). História de la filosofia política. México Fondo de Cultura Económica, 1993, p. 451-485.

John Locke in: STRAUSS, Leo; CROPSEY, Joseph (org,) History of Political Philosophy. Chigaco: The University of Chicago Press, Ltd, 1987

GOUGH, J. W.. A Teoria de Locke sobre a propriedade, in O Pensamento Clássico e Político, org. Célia Glavão Quirino e Maria Tereza Sadek, São Paulo: Martins Fontes, 2003, p. 197 a 218 . A separação de poderes e a soberania, in O Pensamento Clássico e Político, org. Célia Glavão Quirino e Maria Tereza Sadek, São Paulo: Martins Fontes, 2003, p. 219 a 244. John Locke's Political Philosophy, Oxford: At The Clarendon Press, 1973.

GRONDONA, Mariano. Os Pensadores da Liberdade: de John Locke a Robert Nozick, tradução Ubiratan de Macedo, São Paulo: Mandarim, 2000.

GROTIUS, Hugo. O Direito da Guerra e da Paz, tradução Ciro Mioranza, Ijuí/RS: Editora Unijuí, 2004.

HARRIS, Ian. The mind of John Locke, Cambrigde Yniversity Press, 1994.

HART, H. L. A..O Conceito de Direito, tradução, tradução Antonio de Oliveira SetteCâmaras, São Paulo: Marins Fontes, 2009

HEGEL, Georg Wilhelm Friedrich. Filosofia da História, Brasilia: UNB, 1999.

HERNANDES, Isabel Pimenta. Saber e Ação em Locke, Tese apresentada ao Programa de Pós-Graduação em Filosofia, da Faculdade de Filosofia, Letras e Ciências Humanas da Universidade de São Paulo, para obtenção do título de Doutor em Filosofia. São Paulo: 1991.

HIRSCHBERGER, Johannes. História da Filosofia Moderna, trad. Alexandre Correia, Editora Herder: São Paulo, 1967.

HOBBES, Thomas. Do Cidadão, tradução de R. J. Ribeiro, São Paulo: Martins Fontes, 1992. Leviatã, tradução de J. P. Monteiro e M. B. Nizza, São Paulo Martins Fontes, 2003.

JORGE F ${ }^{o}$, Edgar José. Moral e Historia em Locke, São Paulo: Loyola, 1992. 
JORGE, Vladimyr Lombardo. John Locke: lei e propriedade, in Curso de Ciência Política, org. Lier Pires Ferreira e outros, Rio de Janeiro: Elsevier, 2009.

KELSEN, Hans. A Justiça e o Direito Natural, tradução João Batista Machado, Almedina Brasil, 2001.

KENNY, Anthony. Uma Nova História da Filosofia Ocidental: O despertar da filosofia moderna, vol III, tradução Carlos Alberto Bárbaro, São Paulo: Edições Loyola, 2009.

KYMLICKA, Will. Filosofia política contemporânea, tradução Luís Carlos Borges, São Paulo: Martins Fontes, 2006.

KREIMENDAHL, Lothar, org., Filosofia do Século XVII, tradução Benno Dischinger Leopoldo, RS: Editora Unisinos, 2003.

KRISCHKE, Paulo J.. O Contrato Social: Ontem e Hoje, org., São Paulo: Cortez Editora, 1993.

KUNTZ, Rolf Nelson. Locke, Liberdade, Igualdade e Propriedade, in Quirino, Célia Galvão e outros, org., Clássicos do Pensamento Político, São Paulo: EDUSP, 2004, p. 91 -119. A nave da Modernidade, Prefácio, in A Teoria de Jean Bodin, Barros, Alberto Ribeiro. Unimarco, 2001, p. 11-19.

O banquete de David Hume, in Jornal de Resenha, n. 81, 12/01/2002, Jornal de Resenhas, Vol III, São Paulo: Discurso Editorial, 2002, p. 2288-2290.

LAGO, Clênio. Locke e a Educação. Chapecó: Argos, 2002.

LASLETT, Peter. A Teoria Social e Politica dos "Dois Tratados sobre o Governo", in O Pensamento Clássico e Político, org. Célia Glavão Quirino e Maria Tereza Sadek, São Paulo: Martins Fontes, 2003, p. 245 a 278.

LEBRUN, Gérard. O que é Poder, tradução Renato Janine Ribeiro e Silvia Lara, São Paulo: Brasiliense, 2004. Contrato Social ou negócio de otário, in A Filosofia e sua história, p. 225-252. As liberdades dentro do liberalismo, in Passeios ao léu, São Paulo: Editora Brasiliense, 1983, p. 41-51, 
LOCKE, John. Ensaio sobre o Entendimento Humano, vol. I e II,Coordenação de tradução de Eduardo Abranches de Soveral, Lisboa: Edição Fundação Calouste Gulbenkian, 2008.

Ensaios Políticos, tradução Eunice Ostrensky, São Paulo: Martins Fontes, 2007.

Some Thoughts Concerning Education, Coleção: philosophical classics, Dover Publications, 2007.

Segundo Tratado sobre o governo civil e outros escritos: ensaio sobre a origem, os limites e os fins verdadeiros do governo civil, tradução Magda Lopes e Marisa Lobo da Costa, Petrópolis RJ: Vozes, 2006.

Dois Tratados sobre o governo. Tradução de Júlio Fisher, São Paulo: Martins Fontes, 2005.

Cartas sobre tolerância, tradução Jeane B. Duarte Rangel e Fernando Dias Andrade, São paulo: Icone, 2004.

Alguns Pensamentos Acerca da Educação. Tradução de Avelino da Rosa Oliveira e Gomercindo Ghiggi , in Revista Caderno de Educação - FaE/UFPEL, Pelotas, vol. 13 ao 22.

Essays on the Law of Nature, edited by W. Von Leyden, Great Clarendon Street, Oxford, 2002.

Pensamientos sobre la educacion, akal ediciones (1986)

Political Writings, org. David Wooton, USA: Penguin Books, 1993.

Two Treatises of Government, edited by Mark Goldie, Everyman, 1993

LOCKE - Coleção Pensadores - tradução Anoar Aiex e E. Jacy Monteiro, São Paulo: Abril Cultural, 1978.

Two Treatises of Governmen, London: Printed for Awnlban and John Churchill, at Black Swan in pater-Nofter-Row, 1968.

Essays on the law of nature. Great Britain: Oxford, 1954.

LOPES, José Reinaldo de Lima. O Direito na História, São Paulo: Max Limonad, 2000.

LOSURDO, Domenico. Contra-História do Liberalismo, tradução Giovanni Semeraro, SO: Idéias e Letras, 2006.

MACPHERSON, C. B.. A Teoria Politica do Individualismo Possessivo de Hobbes até Locke, tradução Nelson Dantas, Rio de Janeiro: Paz e Terra, 1979. 
MAGALHÃES, João Batista. Locke. A "Carta sobre a Tolerância" no seu contexto Filosófico, Porto: Edições Contraponto, 2001.

MANENT, Pierre. História Intelectual do Liberalismo, tradução Vera Ribeiro, Rio de Janeiro: Imago, 1990.

MELLO, Leonel Itaussu de Alemida. John Locke e o Individualismo Liberal, in Os Clássicos da Política, Vol. I, org. Francsico Welfort, São Paulo:Atlas, 2006.

MICHAUD, Ives. Locke, tradução de Lucy Magalhães, Rio de Janeiro: Jorge Zahar Editor, 1991.

MIRANDA FILHO, Mario, Politéia e Virtude, in Clássicos do Pensamento Político, São Paulo: EDUSP, 2004.

MORAES, Amaury Cesar. Liberalismo e propriedade no "Capítulo V" do Segundo Tratado sobre o Governo de Locke in Direito e Filosofia: A Noção de Justiça na História da Filosofia, p. 75 a 85, São Paulo: Atlas, 2007.

MORRESI, Sérgio Daniel. O Liberalismo Desenquadrado, Tese apresentada ao Programa de Pós-Graduação em Filosofia, da Faculdade de Filosofia, Letras e Ciências Humanas da Universidade de São Paulo, para obtenção do título de Doutor em Filosofia. São Paulo: 2005.

MULLER, Luiza de Souza. John Locke: Ensaios sobre a Lei de Natureza - tradução e comentários. Dissertação apresentada à Universidade São Judas Tadeu para obtenção do título de Mestre em Filosofia. São Paulo: 2005.

NASCIMENTO, Milton Meira do. "Reivindicar Direitos Segundo Rousseau, in Clássicos do Pensamento Político, São Paulo: EDUSP, 2004.

A liberdade e os bens de cada um, in Jornal de Resenha, n. 45, 12/12/1998, Jornal de Resenhas, Vol II, São Paulo: Discurso Editoria, 2001, p. 1339-1340.

O Contrato Social ou As Ilusões do Jogo do Poder, dissertação de Mestrado apresentada ao Departamento de Filosofia - FFLCH/USP, 1978.

Opinião e Revolução: aspectos do discurso político na França revolucionária. São Paulo EDUSP Nova Stella, 1989. 
NODARI, Paulo César. A emergência do Individualismo Moderno no Pensamento de John Locke, Dissertação apresentada ao Departamento de Filosofia, da Faculdade de Filosofia e Ciências Humanas da UFMG, para obtenção do título de Mestre em Filosofia. Belo Horizonte: 1998.

OLIVEIRA, Armando Albuquerque de. Locke: Dos fins da sociedade civil, in Novo Manual de Ciência Política, org. Agassiz Almeida Filho e Vinícius de Campos Barros, São Paulo: Malheiros Editores, 2008.

OLIVEIRA, Manfredo Araujo de Oliveira. Ética e Sociabilidade, São Paulo: Loyola, 1993. OSTRENSKY, Eunice. Otro Locke, in Em El nombre de Dios: razón y revolución em La obra de John Locke, org. Eduardo Rinesi, Buenos Aires: Gorla, 2009.

Introdução, in Ensaios Politicos: John Locke, São Paulo: Martins Fontes, 2007, p. XI - XXXI.

De Harrington a Locke - o conceito de liberdade. Texto apresentado ao Grupo de Iniciação Científica - Faculdade de Ciências Políticas-USP, na data de 04.10.2007.

PATEMAN, Carole. Contrato Sexual, tradução Marta Avancini, São Paulo: Paz e Terra, 1993.

PEREIRA, Ascísio dos Reis. O projeto pedagógico de J. Locke para a modernidade: atualizações necessárias e releituras possíveis, Tese apresentada à Faculdade de Educação da Universidade Estadual de Campinas, para obtenção do título de Doutor. Campinas: 2006.

POLIN, Raymond. O individuo e a comunidade, in O Pensamento Clássico e Político, org. Célia Galvão Quirino e Maria Tereza Sadek, São Paulo: Martins Fontes, 2003, p. 157 a 196. La Politique Morale de John Locke, Paris: Press Universitaires de France, 1960.

PUFENDORF, Samuel. Os deveres do Homem e do Cidadão, tradução Francisco Alves, Rio de Janeiro: Topbooks Editora, 2007.

QUIRINO, Célia Galvão e outro. O Pensamento Político Clássico, São Paulo: Martins Fontes, 2003.

RAYNAUD, Philippe. “LOCKE, John, 1632-1704 - Dois tratados do governo civil, 1690”, in Dicionários de Obras Politicas, coordenação CHATELET, François, DUHAMEL, Olivier e 
PISIER, Evelyne, tradução Glória de C Lins e Manoel Ferreira Paulino, Rio de Janeiro: Editora Civilização Brasileira, 1993.

PAIM, ANTONIO. Evolução Histórica do Liberalismo, Belo Horizonte: Editora Itatiaia, 1987.

REALE, Giovanni, ANTISERI, Dario. História da Filosofia, vol. 4, São Paulo: Paulus, 2005.

REIS, Daniela Amaral dos. A tolerância em John Locke e os limites do poder civil, Dissertação apresentada ao Departamento de Filosofia, da Faculdade de Filosofia, Letras e Ciências Humanas da Universidade de São Paulo, para obtenção do título de Mestre em Filosofia. São Paulo: 2007.

REIS, Francisco de Assis Brandão dos. O Contrato Social como arma de luta Burguesa Hobbes, Locke e Rousseau. Dissertação apresentada ao Departamento de Ciência Política Instituto de Filosofia e Ciências Humanas da Universidade Estadual de Campinas, para obtenção do título de Mestre em Ciência Políticas. Campinas:1988 .

RENAUT, Alain. História da Filosofia Política: Nascimentos da Modernidade, Vol 2, tradução Felipe Duarte, Lisboa: Instituto Piaget, 1999.

História da Filosofia Política: As Críticas da Modernidade Política, Vol 4, tradução Maria Carvalho, Lisboa:Instituto Piaget, 2000.

ROSAS, João Cardoso. Manual de Filosofia Política, (org.) Edições Almedina, AS: Coimbra, 2008.

ROUSSEAU, Jean-Jacques. O Contrato Social: Princípios do direito público, tradução Antonio de Pádua Danesi, São Paulo Martins Fontes, 2003

Do Contrato Social, São Paulo: Martin Claret.

Discurso Sobre Origem e os Fundamentos da Desigualdade entre os Homens. in : Rousseau, “Coleção Os Pensadores”. São Paulo: Abril, 1973.

SABINE, George H. Sabine. História das Teorias Políticas, Vol I e II, Tradução Ruy Jungmann, Editora Fondo de Cultura.

SANTOS, Antonio Carlos dos. O filosofo e o seu tempo, in Os Filósofos - Clássicos da Filosofia, vol. I, org. Rossano Pecoraro, Petrópolis, RJ: Editora Vozes, 2008. 
SANTILLAN, JOSÉ F FERANDES. LOCKE Y KANT, México: Fonde de Cultura Económica, 1992.

SIDGWICK, Henry. História da Ética, Cláudio J. A. Rodrigues, São Paulo: Ícone Editora, 2010

SILVA, Saulo Henrique Souza. A Exterioridade do Político e a Interioridade da Fé, Dissertação apresentada ao Programa de Pós-Graduação em Filosofia, da Faculdade de Filosofia e Ciências Humanas, Universidade Federal da Bahia, para obtenção do título de Mestre em Filosofia. Salvador: 2008.

SOUZA, Paulo Clinger de. A Dialética da Liberdade em Locke, Londrina: Eduel, 2003.

SPITZ, Jean-Fabiens. John Locke et les fondements de la liberté moderne, Paris, Presses Universitaires de France, 2001.

SKINNER, Quentin. As fundações do pensamento político moderno, tradução Renato Janine Ribeiro e Laura Teixeira Motta, São Paulo: Companhia das Letras, 2009.

STRAUSS, Leo. Natural Right na History, Chigaco: The University of Chigaco Press, Ltd., 1971.

Direito Natural e História, tradução Miguel Morgado, Lisboa: Edições 70, LDA, 2009.

TADIE, Alexis. Locke, tradução de José Oscar de Almeida, São Paulo: Estação Liberdade, 2005.

TRAVERSO, Edilia Cassani-. Liberté et Droit Naturel dans L'ceuvre de John Locke, Fribourg: Editions Universitaires Fribourg Suisse, 1993.

TUlLY, James. An Approach to Political Philosophy: Locke in Contexts, Cambridge University Press, 1993.

Discourse on Property: John Locke and his adversaries, Cambridge University Press, 1982.

VILLEY, Michel. A formação do pensamento jurídico moderno, tradução de Cláudia Berliner, São Paulo: Martins Fontes, 2005. 
Filosofia do Direito, tradução Márcia Valéria Martinez de Aguiar, São Paulo: Martins Fontes, 2003.

YOLTON, John W. . Dicionário Locke, tradução Alvaro Cabral, Rio de Janeiro: Jorge Zahar Editor, 1996.

ZINGANO, Marco Antonio de Ávila. Estudos de Ética Antiga. São Paulo: Discurso Editorial, 2007. 